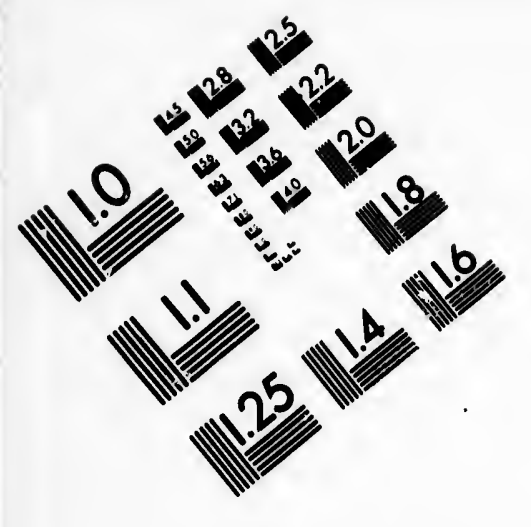

IMAGE EVALUATION

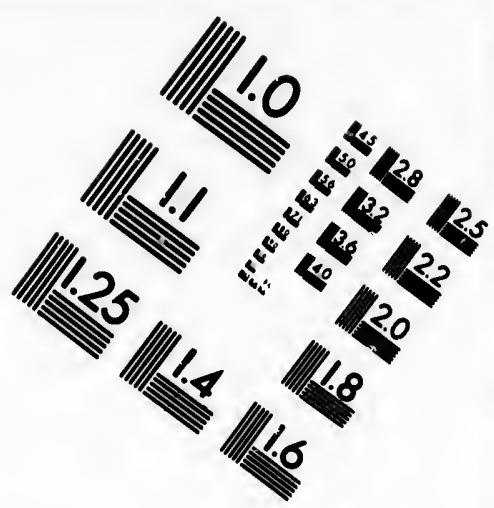

TEST TARGET (MT-3)
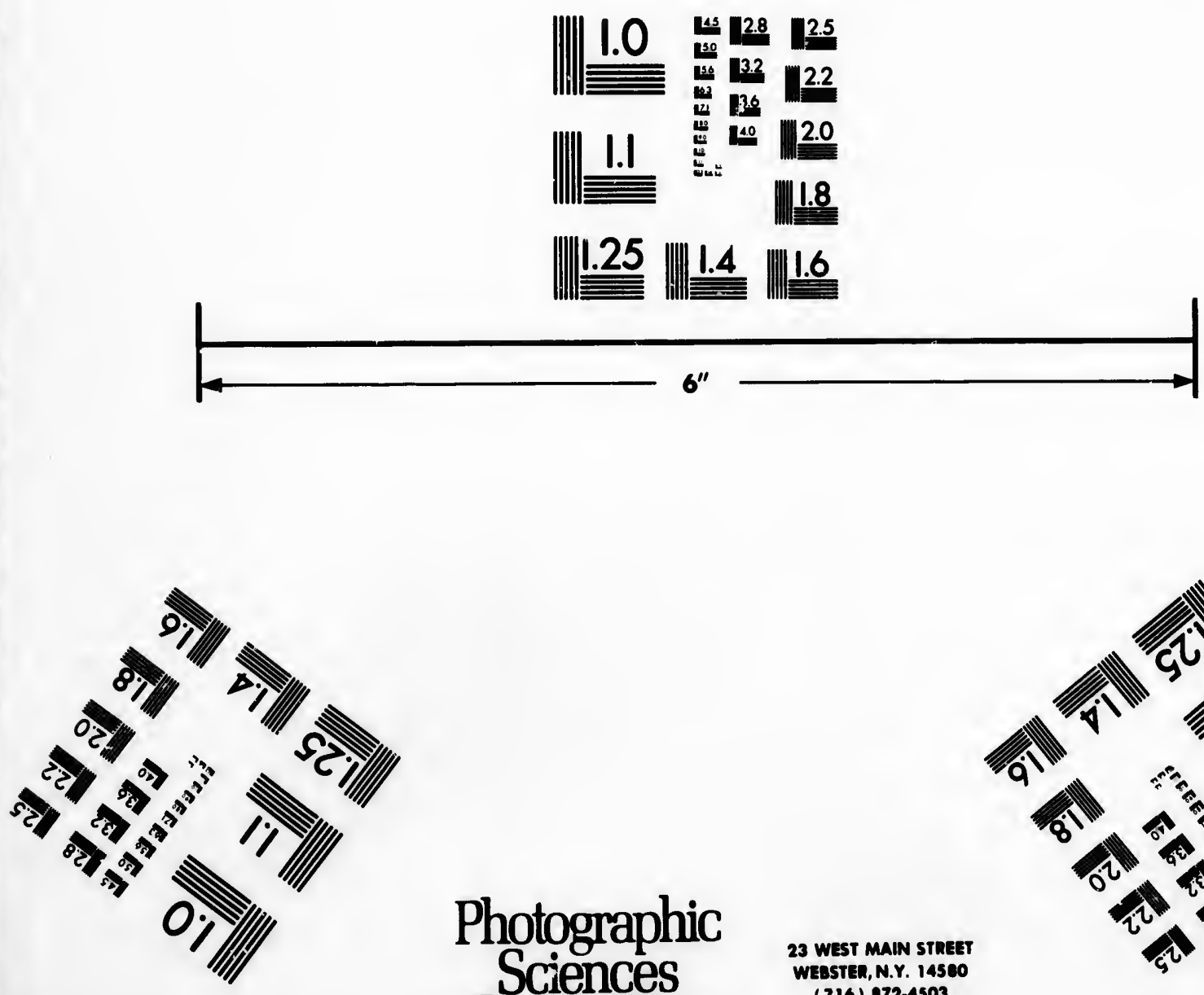

Photographic Sciences Corporation

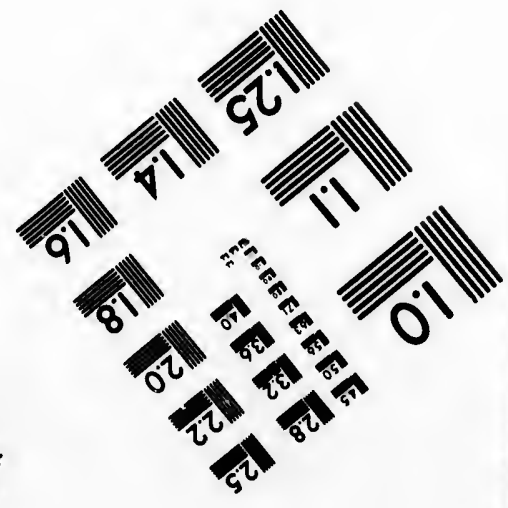




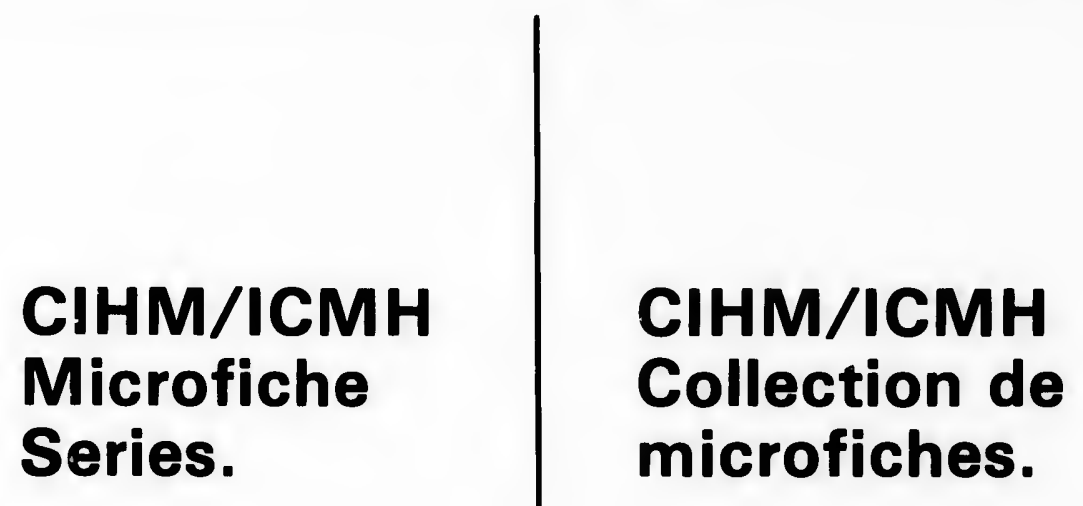

Canadian Institute for Historical Microreproductions / Ins citut canadien de microreproductions historiques
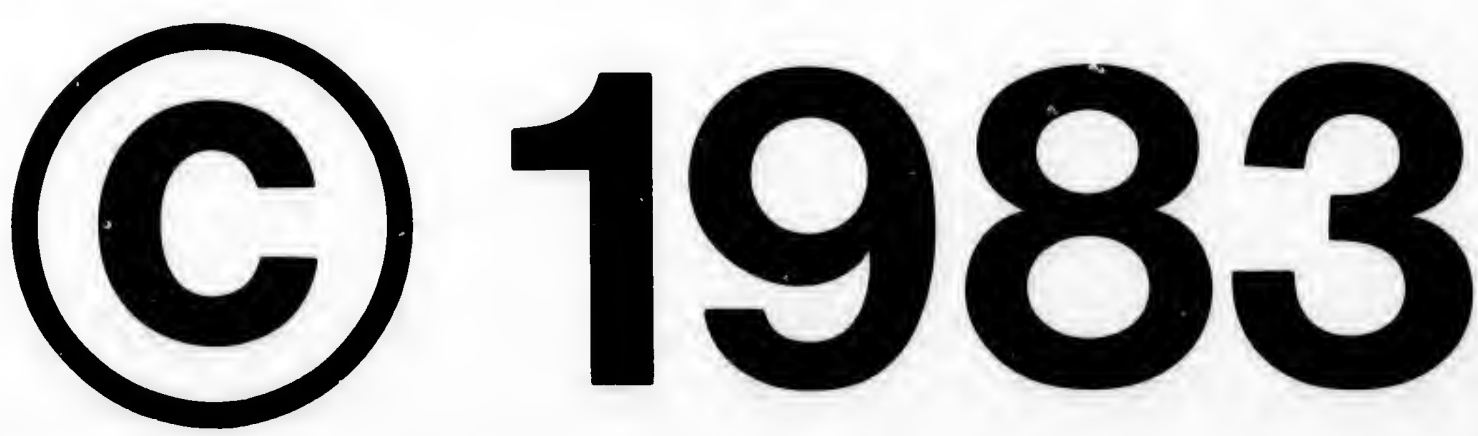
The Institute has attempted to obtain the best original copy available for filming. Features of this copy which may be bibliographically unique, which may alter any of the Images in the reproduction, or which may significantly change the usual method of filming, are checked below.

Coloured covers/

Couverture de couleur

\section{Covers demaged/}

Couverture endommagée

Covers restored and/or laminated/

Couverture restaurée et/ou pelliculáe

Cover title missing/

Le titre de couverture manque

Colour ed maps/

Cartes géographiques en couleur

Coloured ink (i.e. other than blue or black)/

Encre de couleur (i.e. eutre que bleve ou noirel

Coloured pletes and/or illustrations/

Planches ot/ou illustrations en couleur

Bound with other material/

Relié avec d'autres documents

Tight binding may ceuse shadows or distortion along interior margin/

La re liure serrée peut causer de l'ombre ou de la distortion le long de la marge intérieure

Blank leaves added during restoration may appear within the text. Whenever possible, these have been omitted from filming/

II se peut que certaines pages blanches ejoutées lors d'une restauration apparaissent dens le texte. mais, lorsque cela était possible, ces pegas n'ont pas été filr nées.

Additional comments:/

Commentaires supplémentaires:
L'Institut a microfilmé le meilleur exemplaire qu'il lui a été possible de se procurer. Les détails de cet exemplaire qui sont peut-être uniques du point de vue bibliographique, qui peuvent modifier une imaga reproduite, ou qui peuvent exiger une modification dans la méthode normala de filmage sont indiqués ci-dessous.

Coloured pagas/

Pages de couleur

Pages damaged/

Pages endommagées

Pages restored and/or laminated/

Pages restaurées et/ou pelliculées

Pages discoloured, stained or foxed/

Pages décolorées, tachetées ou piquées

Pages detached/

Pages détachées

Showthrough/

Transparence

Quality of print varies/

Qualité inégale de l'impression

Includes supplementary material/

Comprerid du matériel supplémentaire

Only edition available/

Soule édition disponible

Pages wholly or partially obscured by errata slips, tissues, etc., have been refilmed to ensure the best possible image/ Les pages totalement ou partiallement obscurcies par un feuillet d'errata, une pelure, etc., ont été filmées à nouveau de façon à obtenir la meillaure image possible.

This item is filmed at the reduction ratio checked below/ Ce document est filmé au taux de réduction indiqué ci-dessous.

$10 \mathrm{x}$

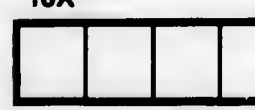

$12 \times$ 1ax

$18 x$
$22 \times$
The $\mathrm{c}$

to the
The it

possil

of thi

filmin

Origi

begin

the la

sion,

other

first

sion,

or illu
The It

shall

TINU

whicl

Meps

differ

entire

begin

right

requil

meth 
The copy filmed here has been reproduced thanks to the generosity of:

Thomas Fisher Rare Book Library,

University of Toronto Library

The images eppearing here are the best quallty possible considering the condition and leglbility of the original copy and In keeping with the filming contract specifications.

Original copies in printed paper covers are filmed beginning with the front cover and ending on the last page with a printed or lllustrated impression, or the back cover when appropriete. All other original coples are filmed beginning on the first page with a printed or illustrated impression, and ending on the last page with a printed or illustrated impression.

The last recorded frame on each microfiche shall contain the symbol $\rightarrow$ Imeaning "CONTINUED"), or the symbol $\nabla$ (meaning "END"), whichever applies.

Maps, plates, charts, otc., may be filmed at different reduction ratios. Those too large to be entirely included in one exposure are filmed beginning in the upper left hend corner, left to right and top to bottom, as many frames as required. The following diagrams illustrate the method:
L'exemplaire filmd fut reproduit grâce à la gónérosité de:

Thomas Fisher Rare Book Library. Unlversity of Toronto Library

Les images suivantes ont ete reproduites avec le plus grand soin, compte tenu de la condition et de le nettoté de l'exemplaire filme, et en conformito avec les conditions du contrat de filmage.

Les exemplaires originaux dont la couverture en papier est imprimée sont filmés en commençant par le premier plat et en terminant soit par la dernidre page qui comporte une empreinte d'impression ou d'illustration, soit par le second plat, selon le cas. Tous les autres exemplaires originaux sont filmés en commençant par la premidre page qui comporte une empreinte d'impression ou d'illustration et en terminant par la dernibre page qui comporte une telle empreinte.

Un des symboles suivants apparaitra sur la derniére image de chaque microfiche, selon le ces: le symbole $\rightarrow$ signifie "A SUIVRE", lo symbole $\nabla$ signifie "FIN".

Les cartes, planches, tableaux, etc.. peuvent être filmés a des taux de reduction differents. Lorsque le document est trop grand pour être reproduit en un seul cliché, il est filmé partir de l'angle supérieur gauche, de gauche à droite. ot de haut en bes, en prenant le nombre d'images nécessaire. Les diagrammes suivants illustrent la méthode.

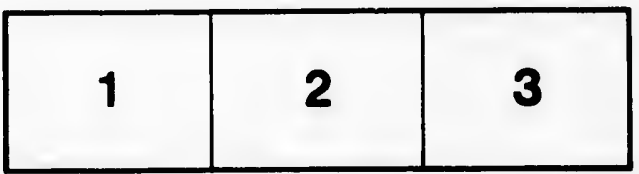

\begin{tabular}{|l|l|l|}
\hline 1 & 2 & 3 \\
\hline 4 & 5 & 6 \\
\hline
\end{tabular}

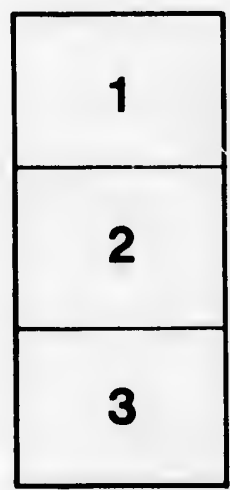



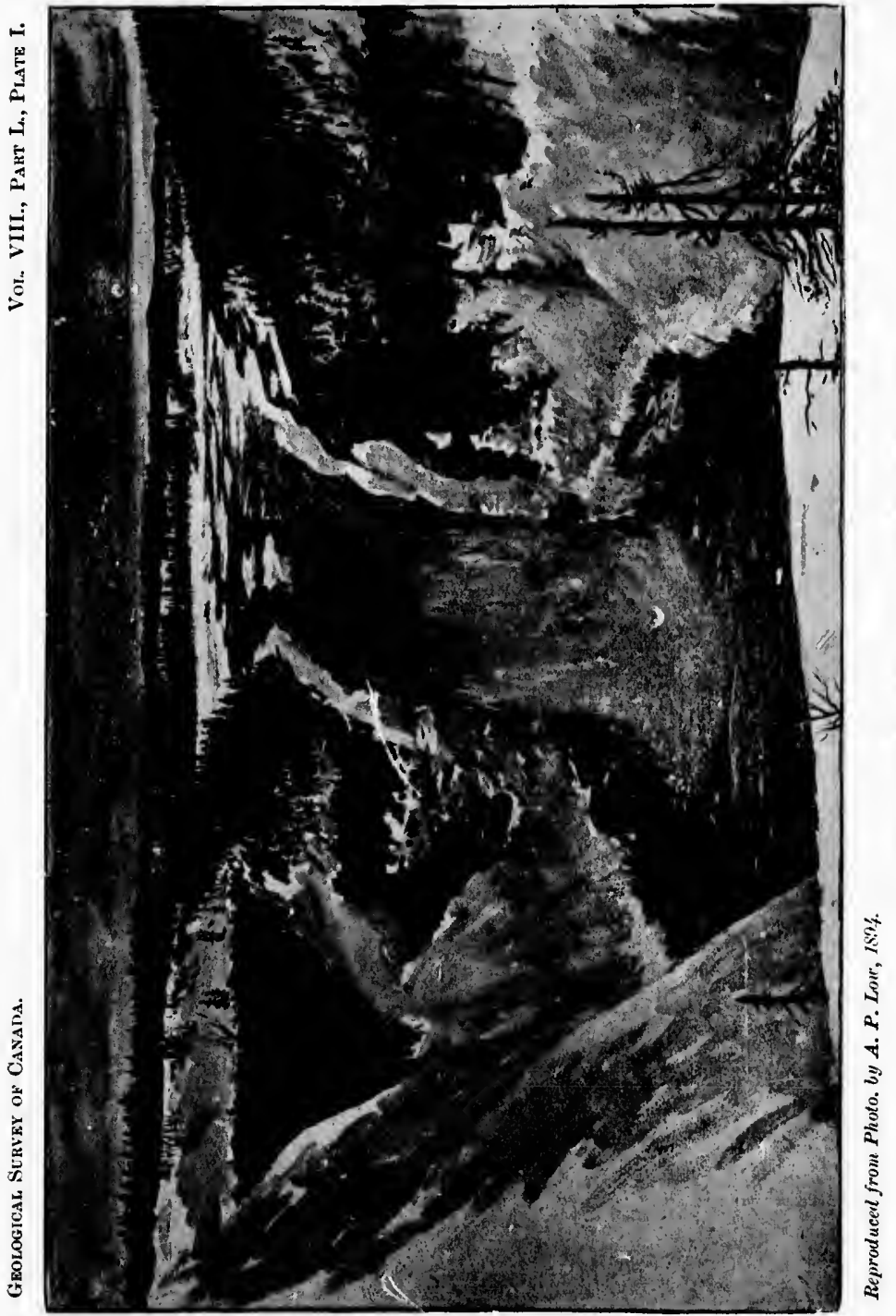

EA 


\title{
GEOLOGICAL SURVEY OF CANADA
}

G. II. DAWSON, C.M.G., LL.D., F.R.S., Director

\author{
REPOR'T \\ OX EXPLOK.TTONS IX THE \\ LABRADOR PENINSULA \\ MLOX: THE

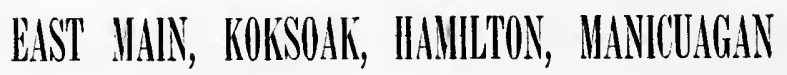 \\ (X) \\ PORTIONS OF OTHER RIVERS \\ Is \\ 1892-93-94-95 \\ BY
}

A. P. LOW, B. AP. Sc.

OTTAWA

PRINTED BY S. F. DAWSON, PRINTER TO THE QUEEN'S MOST EXCELLENT MAJESTY

1896 
To

George M. Dawson, C.M.G., LL.D., F.R.S.,

Director Geological Survey of Canarla.

SiR,-I have the honour to submit herewith a report of niy work in the Labrador Peninsula during the seasons 1892, 1893, 1894 and 1895.

I have the honour to be,

Sir,

Your obedient servant,

A. P. LOW. 
NotE.-All bearings mentioned in this Report refer to the true North. The magnetic variation at the mouth of the East Main River is $17^{\circ}$ west ${ }^{\circ}$ and increases as the river is ascended till at Lake Nichicun it is nearly $30^{\circ}$ west. From Nichicun to Fort Chimo the variation increases gradually to $45^{\circ}$ west at the latter place. At the moutl of the Hamilton River the variation is $38^{\circ}$ west, and along the river it ranges between $30^{\circ}$ and $38^{\circ}$ west, while along the Romaine River it is about $30^{\circ}$ west, and at Lake Mistassini about $20^{\circ}$ west. 


\section{REPORT}

ox

\section{EXPLORATIONS IN THE LABRADOR PENISULA}

ALON: THF

\section{EAST MAIN, KOKSOAK, HAMILTON, MANICUAGAN AND PORTIONS OF OTHER RIVERS.}

\section{Istronectons.}

The present report is based mainly upon the observations made along Sources of the routes of exploration followed during the seasons of 1892,1893 , infornution. $189+$ and 1895. The knowledge so gained has been supplemented by information obtained from officers and servants of the Hudson's Bay Comp:ny, Indians, and other persons acquainted with the Labrador Peninsula. Free use has also been made, in regard to certain subjects, of the information to be found in the writings of Mr. Lucius MI. Turner, ${ }^{*}$ Dr. A. S. Packard, $\dagger$ and Mr. W. A. Stearns, $\$$ who have all spent some time on the southern and eastern coasts and there collected much valuable infornation relating to the history, physical geography and natural history of those regions. Observations on the natural resources of the peninsula made by officers of the Geological Survey in former explorations, have also, when necessary, been incorporated in the text; $a$ list of these explorations is given at the end of the listorical notes.

Acknowledgments are due to Mr. C. C. Chipman, Commissioner of Acknowledg. the Hudson's Bay Company, and to Mr. Peter McKenzie, for circular ment of assistletters to the various officers in charge of posts along the routes travelled, and to the following gentlemen in charge of these pos's : Messrs. J. Broughton, D. Mathewson, Wm. Scott, C. Siuclair, J. A. Wilson, A. Nicholson, H. M. S. Cotter, John Ford, J. Fraser, J. Gordon, W. Miller, J. Iserhoff and J. Corson, for their generous hospitality, valuable information and efficient aid, to which the success of the explorations has been largely due.

- List of birds of Ungava, Proc. U. S. Nat. Museum, VIII., 1885.

Ethnology of [Tngava, Amual Report U. S.. Bureall of Ethnology, 1989-90.

+ The Labrador Coast, New York, 1891.

† Labrador, Boston, 1884. 
Work of axнistnutw,

Previums rejorts.

Route fol. lowed in 1 s:t2.

Konte fol. lowetl in 18!13 and 1894 .
During the season of 1892, Ml. A. H. D. Ross, M.A., ncted as my assistant and besides currying ont other varied duties, made n lurgo collection of plants, which added grently to the botunical knowledge of the eastern watershed. The numes of these phuts have heen in. eluded in the list given in un nppendix. In 1893 , 1894, and 1895, Mr. D. I. V. Eaton, C.F., neted as assistant and topogrupher, and it is entirely to his enreful work thint the exnct surveys of these years aro due. Mr. Eaton, since his return to Ottawa, has ulso compiled the unp which accompanies this report.

Itineraries of the various journeys mule in the euurse of these explorations have been printed in the Summary Reports of the Geologienl Survey Department for 1892, 1894, and 1895), and only a lorief outline of the routes followed neel in consequence be given here.

In 1892, the routes tritversed were from Lake St. Ju!n, up the Chamouchounn River to its heud, thence north-eust through three large lakes to Lake Mistassini. From that lake the enst channel of the Rupert River was descended soine fifty miles, to in portage-1 oute crossing through sinall lakes to the East Muin River fifty miles north wiud. This stream was carefully surveyed downward for three hundred uriles to its mouth on the east side of Jumes Bay. James Buy was crossed to Moose River, and that stream ascended to its hearl, where the Canndian Pacific Railway was renched, making in all a eanoe trip of over thirteen hundred miles. In 1893 and 1894 , tha party remuined in the field during the winter. A start was agnin made from Lake St. John, and the chief branch of the Chamouchouan River was ascended to its head near Lake Mistas-ini. The sume route us that followed the previous year, was taken to the East Main River, where the survey was commeneed at the end of that yere's work, und carried upward to the hend of the river, whre a crossing was mule to the upper waters of the Big River, and that stream was descended to Lake Nichicun. A portnge-route was then followed to Lake Knninpiskau, and the Koksonk River, which flows out of it, was descended to its mouth at Ungava Bay. In this manner a canoe trip through the centre of the Labrador Peninsula from south to north was accomplished. From Fort Chimo, tho Hudson's Bay Company's steanship "Fric" was tnken to Rigolet on Hanilton Inlet. From Rigolet, canoes were taken to Northwest River, at the hend of the inlet, where the early winter was pissed. From the 19th January to the micldle of May, the whole time was employed in huuling the outfit, canoes and provisions on sleds up the Hanilton liver as far as the Grand Falls, some two liundred and fifty miles above the mouth of the river. The months of June and July were occupied in the 
explorntion of the Asluanipi binnch of the Hamilton River to within "h hundred miles of Inke Kinniupisknu, and with the exp'orntion of lake Michikamau. In Auguat a start was made for the eonst by us. cending the Attikonat brunel of the Hunilton River to its hend, nud thence crussing to the Romaine River. This strenin was descended to within one hundred miles of the coust, whence a portage-route wus followoll to the St. John River, and by way of this river the Gulf of St. Lawrence was reached. The total milenge of travel for 1893-9.4 was 5460 miles, mado up as follow + - In cunoe, 2960 miles; on vessel, 1000 uniles; with dog-tenms, 500 miles; and on foot, 1000 miles.

The summer of 1895 was spent in exploring the Manicungan River, Route fol. flowing south ward into the Gulf of St. Lawrenee, which it enters about lowel in t895. 240 miles below Quehec. This strenm was geologicnlly explored to the herad of Mouchalugin Lnke, where the surveys previously made by the Crown Lands Department of Quebec ended. Above this lake the main strenm was surveyed, by mierometer, to its hend in Summit Lake in latitucle $53^{\circ} \mathrm{N}$., and track-surveys were carried over portage-routes on various branches of this river and the head-wnters of the Outardes River nnd of the Big River of Hudson Bay. In so floing a gool iden was ubtuined of the eountry about the centrul watersherl of the peninsula, ay well as considerablo additional information in regurd to the geology und nutural history of the region.

The subjeet matter of this report is sepnrated into two prit:- - The Arrangement first contains a genernl summary of the observations made, and the eon- of matter: elusions renchell from these. It is consequently more eoneise and rendable thun the other part, which eonsists of detuiled deseriptions of the routes, the rocks noted, and other observations for the use of future explorers in the regions traversed. In the part relating to the geology, a summary of the chief observations and deductions is given in con nection with each formation, lefore the detuiled observations are entered upon.

In the Appendices will be found lists and short notes on the mam- Appendices. mals, birds, fishes and insects known to exist in the interior of the peninsuln; also a complete list of plants of Labrador, compiled by Mr. J. M. Macoun, from the various collections male by members of the staff of the Geological Survey and others. A meteorologieal record for 1893-94 is also given in Appendix VII.

\section{Previons Discoreries and Explorations.}

The first European authentically known to have visited the easterr Biame. s!hores of Ameriea was Biarne, the Norseman, who, in 990, sniled 
south-enst from Greenland, and skirting the ahores of Lahrudor and Newfoundland, proceeded soutliward probubly as far as Novin Nestia.

J.rif.

In 1000, Leif, the son of Eric the lied, the first settler in (ireen. land, followed Binrne's truck und landed on the const of Labrudor, which, from its dosolate rocky const, he called Helluland, "Ntrong Land."

latext Nurw Following Lief came severul expeditions of these hnrdy Norse unvivoyugun. gators, who passed southward to "Vinehund the good." The latest Norse voynge was in $134 \pi$, nfter which date knowledge of the American continent was lost for nearly ono hundred and fifty years.

Nakuluwy

According to Humboldt, Sskolney, $n$ Pole, is said to lave unad a voynge to Greenland and Iabrador in 1470 .

Baspue sisher- About this time, or shortly afterwards, the Busque fishermen, in mitn. search of whales, crossed the Atlnntic to the sliores of Lubrarlor and Newforndlund, and appenr to have been met there by the Cabots and Corterenl.

Iolmicalot. In 1497, John Cabot from Bristol, in search of a western passnge to Cathay, sighted the const of Labiador or Newfoundland. In the following year, his son, Sebustien Cubot, suiled fron Englnnd nud skirted the whole Labiador coast to beyond Cape Clidley, where he turned southward past Newfounclland, Nova Scotin and New England in hope of finding a passage to the eastward.

Corterinl. Cortereal, who sniled from Lisbon in 1500, renched Newfoundlnnd, proceeded thence northward, and probably re-discovered Greenlancl.

Brest.

In 1504, the town of Brest was founded by the French on Bradore Bay, near the Strait of Belle Isle. In 1517, hifty vessels called here, and in the height of its prosperity, about 1600, Brest contained two liundred houses and $n$ population of alsout 1000 persons.

Sit. Luwrence. Denis, of Honfleur, and Aubert, of Dieppe, are said to have explored the St. Lawrence as far as the Snguenay in 1509 and 1508 .

Labrador. A Portuguese map of 1520, has the name "Lavrador" applied to Greenland, while the unseparated coasts of Labrador and Newfoundland are called "Bacalhnos" or codfish in the Basque tongue. The name Labrador is derived from the Portuguese word for labourer, and was given to the coast because Cortereal brought home $n$ cargo of natives as slaves.

Jacpues
Cartier.

In 1535, Jacques Cartier explored the Gulf and liver St. Lawrence as far as Hochelaga, and wintered at Quebec. The Saguenny River was examined by Roberval in 1543 . 
Mercator's inup of 1569 , shows the eonst of Lubrudor nnd Ungnva Mereator* Bny, or Hudson Bhy; and as his infornution was obtnined from "mup. Portuguese sources, it is evident that the fishermen of lint country had previously penetruted Hudson strnit.

In 1577 , Martin Frobisher sighted the northern const of Labralor, Martin in about latitude $58^{\circ}$, mol thence sailed northward a short distance Frobintur. into Hudson Struit.

The cod tishery of Labrator anl New foundland had growis so rapidly Fisherirs. that in 1578,150 French, hesides 200 vessels of other nations, were engnged in this industry, together with thirty Biscaynn whalers.

In 1586, John Davis pussed along the Lalundor const and dis. John Inviv. covered two openings, Davis Inlet, in latitude $56^{\circ} \mathrm{N}$. and Ivutoke (Hnuilton) Inlet in latitude $54^{\circ} 30^{\prime} \mathrm{N}$.

Hudsou Strnit was penetratel to Ungava Bny, or Hope's Advance, Weymonth. by Weymouth in 1602.

In 1603, Champlain estahlished the first permanent settlement on Clauplain. the St. Lawrence, at Quobec, n smull trading post having been built in 1600 at Tiubussuc.

Henry Hudson, in 1610, passed through the straits and wintered Henry in the soutliern part of the biny which benrs his name. The following spring he was enst adrift, oll the enst const, by his mutinous crew.

In the following yenr, a ship was sent to his rescue under command Sir Thoman of Sir Thomas Button, who entered Hudson Strait by a narrow chan. Buttom. nel south of Cape Clidliey, crossed the bay, and wintered at the mouth of the Nelson River.

About the yeur 1630, the town of Brest and four leagues of coast kiskimo exon each side was granted to a noble named Courtemanche, who had peetled froun married a diughter of Henry IV, ; and the Eskimo, who had given St. Lawrence. the French much trouble, were expelled from the Gulf shores about the sume time.

The quest of the north-west passage brought out James nnd Fox, in Jumex and 1631, to Huilso: Bay, where Jumes wintered on Charleton Island.

In 1641 , the missionary, Jeun de Quen, ascended the Snguenny and discovered Jake St. Johur.

The Sovereign Council of Quebec, in 1656, authorized Jean Bourdon Jean liour. to make discoveries in Hudson Bay. He proceeded there, took pos- don. session in the name of the French King, and made treaties of alliance with the Indians.

In 1658, a lease of exclusive trading, hunting and fishini privileges Le Traité de was given by the King of Frunce to Sieur Demaure. ihis lease Trudoussac. 
was called "Le Truité de Tadoussac," and the tertitory to which it applied was cal'ed the King's Domain. It extended along the St. Lawrence from Isle aux Coudres to a point two leagues below Seven Islands, and included the country northward to the hends of the river's draining into the St. Lawrence. The trading stations established in this territory were called "Postes du Roi," or King's Posts. The lease passed to the "Compagnie des Postes du Roi," and was renewed every twenty-one years. After the cession of Canada, the lease was continued in the same nnanner by the English government. When it was renewed by the Hudson's Bay Company, in June, 1842, for another term of twenty-one years, the Crown reserved the right to subdivide the country into townships for purposes of settlement. The Hudson's Bay Company's lease was ended by linitation in 1859 .

P'ère Dahlon. In 1661, Père Dablon, a Jesuit, and Sieur de Vallière were ordered by d'Argenson, at that time Governor of Canada, to proceed to the country about Hudson Bay. They went there apparently by way of the Saguenay and Rupert rivers. Subsequently, the French company, in their clispute with the Hudson's Bay Company, claimed that they had at that time erected a small post at th" mouth of the Rupert River for trade with the Indians, who had asked at Quebes that a missionary and traders be sent among them.

Sieur de la Conture.

In 1663 , the Indians from about Hudson Bay again returned to. Quebec to renew their former request for traders, and Sieur de $l_{i l}$ Couture, with five men, procecded overland to the bay, took possession in the King's name, noted the latitude, planted a cross and deposited His Majesty's arms, engraved on copper, at the foot of a large tree. In the same year, Sieur Duquet and Jean L'Anglois also visited the bay, and set up the King's arms by orders of d'Argenson.

Radisson and In 1667, Radisson and Chouart dit Groseilliers ascended to Lake Chonart. Superior, and thence crossed to Hudson Bay. They returned to Quebec, and proposed to the merchants to conduct ships to Hudson Bay, but, their proposal being rejected, they went to Paris, where they met with no better success. From Paris they were sent by the British ambassnlor to London, where their proposal was well received by certain mer. chants. In 1668, a small vessel was fitted out under command of Zachray Gilham, who, accompanied by the two Frenchmen, sailed to the southern part of the bay, and wintered in a small building called Fort Charles, at the mouth of the Nemiskaw, or Rupert River.

Hudsou's Bay In 1669, on the return of Gilham to London, Prince Rupert and Company. others applied to King Charles II. for a charter, which wns granted them under the title of the "Governor and Company of Adventurers. Trading from England to Hudson's Bay." 
In the following year, the company sent out Chas. Bayly to estab- Firut settlelish a post at Rupert River. He was accompanied by Chouart and ${ }_{\mathrm{H} \text { udson }}^{\text {man }}$ Bay. Radisson, and remained in the country, thus inaugarating the first permanent English settlement on Hudson Bay.

In 1674, Charles Albanel, a Jesuit missionary, arrived at the Eng- P're Albanel. lish settlement with letters from the Governor of Quebec, who had despatched him in 1672 , overland from Quebec, to see what the English were cuing on the bay. The route iollowed by Albanel was up the Saguenay River to Lake St. John, thence by the Chamouchouan River to the height-of-land and Lake Mistassini, and down the Rupert River to its mouth. An account of his trip is given in the Relations of the Jesuits, and is the first clescription of this portion of the country.

In 1675, outposts were established at Moose and Albany, and a Establishdepot on Charleton Island, where the ship from England discharged ment of Moose her cargo and took on board the furs from the various posss, brought there in sloops.

By 1685, the company had forts at Albany, Moose, Rupert, Nelson and Sevorn; also a small post on the East Main, or "Ison-glass River," where a mica mine was worked, but was soon abandoned as unprofituble.

In March, 1686, the directors of the French Company, on represen- Warare betation of the harm done to their trade by the English on the bay, tween French obtained from M. de Denonville a body of Canadian and regular troops, at Hndson under the command of M. de Troye. They were sent overland, Bay. reaching Hudson Bay in June, and captured Forts Rupert, Moose and Albany. This was the beginning of a desultory warfare, carried on with varying success, between the French and English for a number of years, until the Treaty of Ryswick in 1697. The seventh clause of the treaty restored to each belligerent the possessions lield previous to this war. The eighth clause appointed commissioners to exumine and determine the rights of either of the kings to places in Hudson Bay ; " but the possession of those places which were taken by the Frencl during the peace that preceded the present one, shall be left to the French by virtue of the foregoing article." In consequence, the only post left to the Hudson's Bay Company was the fort at Albany.

'In 1700, the Hudson's Bay Company addressed a cominunication to Boundary the Lords of Trade in reference to their boundaries. They proposed clained by the Albany River, or the 53rd parallel of north latitude, as the Company. boundary on the west coast of the bay, and the Rupert River as the boundary on the east const. The French were ready to accept the 
55th parallel of north latitude, but this the company refused to agree to. In answer to the Lords of Trade, in 1701, the company made the further offer as to the limits between themselves and the French:"2. That the French be limited not to trade by wood-runuers or otherwise, nor build any house, factory or fort, to the northward of Hudson's River, on the east main or coast."

Treaty of Utrecht.

Bumndary claimed ly Hudkon's 13 Company.
Matters remained unsettled until the Treaty of Utrecht in 1713, when the French ceded all their rights to Hudson Bay to the English.

In 1712, the company in a memorial to the Lords of Trade, and later in 1714 , proposed for a settlement of the boundary between their territory and the French, "That the said limits begin from the island called Grimmington's Island or Cape Perdrix (Cape Mugford) in the iatitude of $58 \frac{1}{2}$ degrees north, which they desire may be the bousdary between the English and the French on the coast of Labrador, towards Rupert's Land on the east main, and Nova Britannia on the French side."-_" That a line supposed to pass to the southwestward of the said island of Grinmington or Cape Perdrix to the great Lake Miskosinke at Mistoveny, dividing the same in to two parts as in the map now delivered "- "and from the said lake to run southward unto 49 degrees north latitude."

Delisle's may. The map made by Delisle in 1703, shows the knowledge possessed by the French at the tine of the Treaty of Utrecht of the interior of the Labrador Peninsula. On it is marked Lake Mistassini, discharging into James Bay, and also into Lake St. John. Pletipi, Manicuagan and Nichicun lakes are in their respective places, but the last is made to drain through Lake Pletipi into the Outardes River. At the head of the Peribonka River, there is a large lake named Outakouami, which discharges also into the East Main River, and a large stream flowing northward with the following note:- " $R$. que les sauvages disent tomber dans la mer du nord après 60 lieues de cours:" and the bay is shown in part near latitude $55^{\circ}$, with a break between it and "Bay du Sud" (Ungava), which extends southward between latitudes $61^{\circ}$ and $57^{\circ}$. Hamilton Inlet is marked by a long narrow bay, without any large rivers at its head. The country northward of the East Main River and the eastern part of the southern watershed appear to have been unknown. Indefinite and rough as the topography of this map is, still it is greatly in advance of the English maps published about this time, which show only Lake Mistassini and the Rupert and East Main rivers in the interior of the Labrador Peninsula. 
From the Treaty of Utrecht until after the cession of Canada, Hudwon's Bay the Hudson's Bay Company appears to have confined its trade and investigations on the east side of the bay wholly to the const. In 1732, a small post was re-established at the mouth of the East Main River, which was shortly afterwards made the headquarters of the east coast, and continued as such until after 1820, when two districts were established on this side of the bay, with headquarters at Rupert and (ireat Whale rivers. About the time of the re-establishment of East Main, a post was opened on Richmond Gulf for trade witlı the Eskimo, but was soon abandoned, after two massacres by the natives.

An ordinance respecting the limits of the King's Domain, issued 'Trading posts. at Quebec in 1733, makes mention of the posts of Tadoussac, Chekou- in the king's timy, Lac St. Jean, Nikaubau, Mistassinoc, Papinachois, Naskapis, River Moisie and Seven Islands, showing that the lessees were well established throughout that territory. No records are obtainable of the other districts, seigniories, and fur leases granted at Quebec, but the above may be taken as an example of the mauner in which the French traders had penetrated and established posts throughout the interior of the Indian country, many years previous to the English occupation of Canada. The trajers and "coureurs des bois" must have travelled far into the interior of the Labrador Peninsula, where they lived the grenter part of the time with and like the Indians, only returning to Quebec for a short time every two or three years. IIuch of the information obtained by these men was never recorded and is consequently lost, while the little that was written is very difficult of access.

In 1732, Joseph Normandin was sent by the governor to explore Joseph Norand survey the region about Lake St. John. He ascended the mandin. Chamouchouan River to Lake Nikaubau, and mentions Peltier post as well as one on Ashouapmouchouan Lake, which was first established in 1690 .

Shortly after the concuest of Canada, the North-west Company was North-west formed, and appears to have acquired, among others, the lease of the Conpany. "King's Domain." Under its vigorous management, the fur trade in the North-west and Canada rapidly increased, and this company soon became antagonistic to the Hudson's Bay Company, which now began the establishment of inland posts. The first of these, inland on the east side of Hudson Bay, probably dates from this period; it was situated on the East Main River, abont three hundred miles above its Postinland on mouth, at Birch Point, where a portage-rrute leads southward to Lake the Fast Main 
Mistassini. Subsequently, and before the amalgamation of the Hud son's Bay and North.west companies, this post was removed to the outlet of Lake Mistassini, and again to its present position on the southwest bay, where the North-west Company also had a post on a long narrow point, a few miles to the southward. This appears to have been the only inland post of the Hudson's Bay Company established in Labrador prior to the amalgamation of the companies in 1821.

Labrarlor Compary.

Lahrador Coast under juriscliction of land.

Moravian Missionaries.

Major Cartwright.

Labrador Const.

Hamilton Inlet.

André Mich. and.

Labrador againattached to Newfound. land.
Shortly after the conquest of Canada, the town of Brest, and one hundred and fifty miles of the north shore of the Gulf of St. Lawrence to the westward of that place. was granted to the Labrador Company of Quebec, with exclusive rights to the fisheries and fur trade. In this manner the entire north shore of the gulf was closed to private enterprise, and long renuained so, as the coast to the westward of the Labrador Company's concessions was held by the seigniors of Mingan, whose grant extended to the eastern limit of the King's Domain.

In 1763 , the southern and eastern coasts of Labrador were placed under the jurisdiction of the Governor of Newfoundland; and the eastern and northern boundiries of the province of Canada were defined by the St. John River to its head, and from there by a line drawn through Lake St. John to Lake Nipissing.

In 1770, the Moravian missionaries first settled anong the Eskimo on the Atlantic coast.

About the same time Major Cartwright made settlements at Cape Charles and Sandwich Bay, bringing with him a number of people from Dartwouth, for the salmon fisheries and trade with the Eskimo and Indians.

In 1773 , the coast of Labrador was restored to the jurisdiction of the Governor of Canada, on account of disputes between Newfoundland and the Labrador Company.

In 1777, the first English entered Hamilton Inlet for purposes of trade with the natives, and found there the remains of posts erected hy the French prior to the secession. The first posts were established on the inlet, by a Quebec Company, in $\mathbf{1 7 8 5}$.

André Michaud the celebrated French botanist, in 178: passed through Lake St. John and reached Lake Mistassini. He had intended to descend the Rupert River to James Bay, but was obliged to return from Lake Mistassini, on account of the lateness of the season.

In 1809, the eastern const of Labrador was again attached to the Government of Newfoundland, but the area of coast was reduced, and extended only from Anse Sablon northward to Hudson Strait. 
In 1811, the Moravian missionaries Kollmeister and Kmoch, ex-Kollmeister plored the northern Atlantic Coast and Ungava Bay, and reported and Kmoch. favourably on the climate and soil of the latter place.

The Labrador Company was dissolved in 1820 , and that part of the Labrador Gulf shore previously under its control was thrown open to settlement Company. and private fisheries.

After the amalgamation of the Hudson's Bay and North-west com- Explorations panies in 1821 , the policy of the formet appear's to have changed; and East of $\mathbf{H u d}$. the country to the east of Hudson Bay was shortly after explored, posts being established throughout the interior of the peninsula.

In 1814, the Rev. Mr. Steitihaur published in the Transactions of the Rev. Mr. Geological Society a short description of the Atlantic coast, together Steinhaur. with notes on the various rocks found about the Moravian mission stations.

Between 1821 and 1824, James Clouston was employed in exploring James Clous. the country east of Hudson Bay. There are no wrailable notes or ton's explorrecords of his travels, and all that remains is a map on a small scale, showing the routes that he folluwed. These embrace the East Main River to the Tichagami Branch, a few miles beyond the old post of Birch Point, two portage-routes between the East Main and Rupert rivers, the Rupert liver and Lake Mistassini, and the routes to Waswanipi on the Nottaway River. The original nap is at Great Whale River post, where a tracing of it was made in 1888 , which is now in the Geological Survey office.

In 1824, a party was fitted out at Mloose Factory to proceed over- Establishland to Ungava Bay and there establish a post; but it was not until ment of Fort three years later that this was accomplished by Dr. Mendry, who coasted alcng the east shore to Richmond Gulf, and then passed inland to Clearwater and Seal lakes, thus reaching the head-waters of the Larch Branch of the Kok roak River, which was descended to near its mouth, and Fort Chimo there first estahlished. This trip is the basis of Ballantyne's "Ungava" a popular story for boys. A map made of the route by Dr. Mendry, is at present at Moose Factory, and a tracing of it is in the Geological Survey office ; the part between Clearwater Lake and the forks of the Larch River has been used, in the compilation of the map accompanying this report.

In 1824, the Governor of Newfoundland was empowered to institute a court of civil jurisdiction along the coast of Labrador.

Between $182 i$ and 1829, Admiral Bayfield made charts of the Admiral Bay. Atlantic and St. Lawrence coasts for the British Admiralty. 
In 1827 , the first survey of Lake St. John was made for the Quebec Government by Larue.

John IIcLean. In January and February of 1838, John NcLenn, then in charge at Fort Chimo, crossed overland to Hamilton Inlet, where the Hud-on's Bay Company had estublished posts in $183 \bar{i}$, passing on the way through Lake Michikamau. He retraced the route and reached Fort Chimo again on the 20tl April. The same year a pust was established at Erlandson's Lake, which appears to have been situated on the head waters of the Whale River. Another outpost was also established on the Geprge River.

Discovery of the lirand Falls, Hainil. ton River.

Fort Nas. caupee.

Map of the interior of Labreudor Peninsula.

In 1839, McLean again sturted across to Hnmilton Inlet with cunoes, but reached only the Grand Falls of the Hamilton River, and thus had the honour of being the first white man to view this mighty cataract. Not having a knowledge of the portage-route past the falls, he was obliged to return withor. reaching his destination. In the following summer he was more successful, and reached Hamilton Inlet with canoes, ns be also did in the two following yeurs. An interesting account of McLean's trips and nlso much information concerning the country, is given by him in his book entitled "Twenty-five yenrs in the Hudson's Bay Territory."

In 1840, Fort Nascaupee was estnblished on Lake Petitsikapau, drawing its supplies from Hamilton Inlet, and the poit of Krlandson's Lake was then abandoned. This was followed in 1853 by the temporary withdrawal of the Hudson's Bay Company from Fort Chimo and other posts belonging to it.

In 1842, John Beads and John Spenser, at Nichicun and Lake Kaniapiskau, compiled a map of the region surrounding these plince giving the various branches and lakes of the rivers draining southward, westwaid and northward, from the central portion of the peninsula. This map was found at Nichicun in 1893, and is now in the Geological Survey office. It has been used largely in the compilation of the unsurveyed parts of the map accompanying this report.

List of trading In his evidence before the select committec of the House of Composts. mons on the Hudson Bay's Company, 185̃, Sir George Simpson made a return of the various posts and number of Indians attached to each, throughout the territories of the company. The following list shows the posts then situated in the Lobractor Peninsula:-Chicoutimi, Tadoussac, Isle Jeremie, Godbout, Seven Islands, Mingan, Musquarro, Natasquan, Northwest River, Rigolet, Kibokok, Great Whale River, Little Whale River, Firt George and Rupert House, all located on the coast, and Mistassini, Temiskami, Waswanipi, Mechiskan, Pike 
Lake, Lake St. John, Nichicun, Kaniapiskau and Fort Nascaupee in the interior.

In 1860, A. F. Blaiklock surveyed the Mistassini and Chamou- A. F. Blaikchouan rivers flowing into Lake St. John. Since that date, under the direction of the Quebec Department of Crown Lands, all the principal Surveys by rivers of the southern watershed have been carefully surveyed to near Lands Dotheir sources; and but little work remains to be done to complete the map of the rivers of this slope.

The same year an expedition was sent by the Unitid States Govern- United States . ment, and a station was established on the Atlantic coast in latitude Coast Survey $59^{\circ} 54^{\prime}$, to observe a solar eclipse. In the report of the United States tion. Coast Survey, 1860, a short account of the voyage, with notes on the climate, together with a chart of. Eclipse Harbour is given by Commander Alexander Murray; and notes on the geology of the northern coast of Labrador by Oscar M. Leiber.

In 1862, Henry Yule Hind ascended the Moisie River about 150 Henry Yule miles; and wrote two volumes on his experiences and information Hind. gathered from Indians and other sources relating to the interior of Labrador. This book is still quoted as the stand ird authority on the Labrador Peninsula.

In 1860 and 1864, Dr. A. S. Packard visited the Atlantic coast, and A. S. Packard. besides various earlier papers on the fauna and flora, published in 1891, a work entitled "On the Labrador Coast," which deals very fully with the history and natural resources of the Atlantic coast, and is a valuable addition to the bibliography of Labrador.

In 1866, the Hudson's Bay Company again established Fort Chimo, Fort Chimo and shortly afterwards opened posts at George and Whale rivers, re-established. where extensive salmon and porpoise fisheries are still curried on, besides trade with the natives.

Between 1866 and 1870, Père Babel, O.M.I., travelled inland from Père Babel. Mingan,-and lived with the Indians, exploring with them both branches of the Hamilton River, and the headwaters of many of the streans of the southern slope. A map made during his wanderings, is kept at the nission station of Betsiamites, and when consideration is taken of his imperfect instruments and other disadvantages; its accuracy is wonderful.

About 1875, the Roman Catholic missionaries visited and estab. Romnn lished a mission for the Indians at Northwest River; and during the $\begin{aligned} & \text { Catholic } \\ & \text { missionaries. }\end{aligned}$ two following summers, Père Lacasse crossed overland from that place to Fort Chimo, returning in the Hudson's Bay Company's vessel. 
Moravian missionaries.

Abandonment of interior trading poste.

Jurisdiction of Newfoundland.

Hudson Strait exploration.

Rev. Mr. Peck.

Lucien M Turner.

R. F. Holmcs. In 1887, Mr. R. F. Holmes attempted to reach the Girand Falls of the Hamilton River from its mouth, but, being handicapped with a heavy boat and a poor crew, reached only Lake Winokapau. He marle an excellent map of the river to that point, and wrote an account of his trip, which appeared in the Transuctions of the Royal Geographical Society.

Expeditions II) Hamilton River.

In 1873, the Moravian missionaries published two maps of the Atlantic const; the northern sheet extending north ward from latitude $57^{\circ}$, the southern sheet embracing the coast from Hopedale to Sandwich Bay.

With the establishment of posts on Ungava Bay, the Hudsou's Bay Company abandoned their interior posts on the Hamilton River, and at Lake Michikamau. Fort Nascaupee and Michikamau were closed in 1873, and the post at the head of Lake Winokapau in 1874. The closing of these posts now leaves only Nichicun, Mistassini and Waswanipi in the interior of the peninsula.

In 1876, the extent of the jurisdiction of the Government of Newfoundland in Labrador, was defined in Letters Patent constituting the office of Governor and Commander-in.t/hief of the Islund of Newfoundland. "All the coast of Labrador, from the entrance of Hudson Straits to a line to be diawn due north and south from Anse Sablon on the said coast to the fifty-second degree of north latitude, and all the islands adjacent to that part of the said const of Labrador."

In 1884 and 1885, the Dominion Government sent a vessel to Hudson Strait, to establish observation stations on both sides, in order to obtain reliable information concerning the anount and novements of tle icc.

In 1885, the Rev. Mr. Peck, of the Church Mission Society, crossed from Richmond Gulf to Ungava Bay, following the route previously taken by Dr. Mendry.

During 1885 and $1886 \mathrm{Mr}$. L. M. Turner was engaged collecting birds and mammals, and doing other scientific work in the vicinity of Fort Chimo for the Smithsonian Institution at Washington.

In 1891, two separate expeditions from the United States ascended the Hamilton River, and visited the Grand Falls within a few days of each other. Messrs. Austin Cary and D. M. Cole * who were the first to reach the falls, had the misfortune to burn their boat and outfit, and were obliged to tramp to the mouth of the river, two hundred and

* Bulletin American Geog. Soc., vol. xxiv., p. 1. 
fifty miles distant from where the mishap took place. This they very pluckily accomplished, passing unseen Messrs. Henry G. Bryant* and C. A. Kenaston, who were on their way up the river at the time.

19 following is a list of the reports relating to the Labrador Pen- Explorations insula published by the Geological Survey of Canada, from explorations the Geological made by members of the staff :-

Survey.

Report, 1853-56. - On the Is]and of Anticosti, and the Mingan Islands, - J. Richard

Report, 18\%7.-On part of the Gaspes Peninsula from Magdalen River to Gas]e Bay, and on Lake St. John. -,J. Richardson.

- On the Fauna of portions of the Lower St. Lawrence, the Saguenay, Lake St. John, etc. $-\mathbf{R}$. Bell.

Report, 18tiff-(fi1. - On the north shore of the Lower St. Lawrence.-J. Richardson Report, 1870-71.-On the geology of the country north of Iake St. John.-T. Richardson.

Requrt, 1871.72.- On exploration of Country between Lake St. John and Lake Miatassini. -W. MIcOuntt.

Report, 1877.78. - Keport on an Exploration of the Fast Coast of Hudson Bay.R. Bell.

Report, 1879-80, - Report on Hudson Bay and some of the Lakes and Rivers lying to the west of it. - R. Bell.

Report, 1882-83-84. - Observations on the Coast of Labrador and on Hudson Strait and Bay. $-\mathrm{R}$. Bell.

Report, 1885,-Report of the Mistassini Expedition.-A. P. Low.

" Observations on the Geology, Zoology and Botany of Hudson

Rejort, 1887.88, - Rejort on Fxplorations in James Bny and the Country east of Hudson Bay, drained by the Big, Great Whale and Clearwater Rivers:-A. P. Low.

\section{Pinsical Geography.}

The eastern coast of the Labrador Peninsula extends north-north- Boundaries of west, from the Strait of Belle Isle to Cape Chidley, a distance of Peninsula. about seven hundred miles, or from latitude $52^{\circ}$ to latitude $60^{\circ} 30^{\prime}$, fronting the North Atlantic. The northern boundary from Cape Chidley to Cape Wolstenholme, at the entrance of Hudson Bay, in a straight line, is nearly five bundred miles long, and runs about west-north-west in direction, forming the southern shore of Hudson Strait including Ungava Bay. A line drawn from Cape Wolstenholme to the bottom of James Bay, runs nearly north-and-south for eight hundred miles, and corresponds closely to the eastern shore-line of the peninsula. The southern boundary is arbitrary but has been taken as a straight line extending in a direction nearly east from the south end of James Bay near latitude $51^{\circ}$, to the Gulf of St. Lawrence near Seven Islands in latitude $50^{\circ}$. This line is nearly six hundred miles long, and passes close to the south end of Lake Mistassini. From where the line reaches the Gulf coast, in the neighbourhood of Seven Islands, the shore-line forms the southern boundary to the Strait of Belle Isle, with a length of somewhat over five hundred miles.

* A Journey to the Grand Falls of Labrador, Geog. Club, Philadelphia. $2 \frac{1}{2}$ 
Extent.

Atlontic Cunst.

The total area embraced within these boundaries is approximately 511,000 square miles, of which, previous to the present explorations, 289,000 square miles were pructically unknown. There still remains about 120,000 square miles of the northern portion of the peninsula, between Hudson and Ungavn bays, totally unknown to anyone except the wandering bands of Eskimo who occasionally penetrate inland from the coust.

The Atlantic const is exceedingly irregular, being deeply cut by many long narrow bays, or fiords, so that the const-line exceeds many times the direct distance from Belle Isle to Cape Chidley. Hamilton Inlet is the largest and longest of these inlets, extending inlund over one hundred and fifty miles from its mouth. Among others, Sandwich, Kaipokok, Saglek and Nachvak bays are from thirty to fifty miles deep. These narrow fiords are surrounded by rocky hills that rise abruptly from the water to heights ranging from 1000 feet to 4000 feet. The water of the inlets is generally deep and varies from ten to one hundred fathoms. A fringe of small rocky islands extends almost continuously along the coast, wiv' a breadth of from five to twenty-five miles. Outside the islands, the inne - banks extend seaward for an average distance of about fifteen milis, and on them the water is rarely over forty fathoms deep. From this it will be seen that the fiords, as a rule, have greater depths than the banks outside the island fringe.

Formation of To account for such an apparent anomaly, it is necessary to consider fiords. the formation of both the fiords and banks. The fiords appear to be valleys of denudation of very aneicnt origin, eroded, at least in part, when the elevation of the peninsula was considerably greater (at least 600 feet) than at present. Their remote antiquity is established by the deposition in their lower levels of undisturbed sandstones of Cambrian age. The banks are likely of comparatively recent formation, and appear to be made from material carried off the higher lands by glaciers and deposited by them as a terminal moraine among and outside the fringe of islands, to be subsequently flattened out by floating ice and currents, thus filling up the deep channels at the mouths of the fiords.

Northern coasts.

The coast adjacent to Fudson Strait and Ungava Bay has not been examined closely, but enough is known for us to state that it is generally bold, with highilands rising immedintely from it. Small rocky islunds form a narrow fringe in many places, especially about Ungava Bay, and the coast is indented with small bays, but not to such an extent as the Atlantic coast. 
Hope's Advance is a western extension of Ungava Bay, as yet un- Dangerous explored. The navigation of Ungava Bay and Hudson Strait is currents. rendered dangerous to sailing craft by the strong currenty and exceedingly high tides, the latter having a mean rise in Ungava Bay of nenrly forty feet, and at exceptional spring-tides they have been known to rise sixty feet.

From Cape Wolstenholme to near Cape Jones, at the entrance to Coant of James Bay, the eastorn const-line of Hudson Bay is high and rocky, Hundson Bay. 'The coast between the entrance to Hudson Strait and Cape Dufferin, a distance of nearly three hundred miles, has not yet been continuously explored. Mosquito Bay is situated along this part of the coast, and was fornerly supposed to connect with Hope's Advance. Such has since proved not to be the case, and Mosquito Bay has been found to extend inland not more than seventy-five miles. Between this bay and Cape Dufferin, there is a fringe of islands stretching out from ten to twenty miles from the mainland. To the southward of Cape Dufferin, the coast-line remains high, and an almost continuous line of high islands of Cambrian rocks forms a safe channel for small boats, as far south as Great Whale River. This channel varies from two to eight miles in width. South of Great Whale River, to within a short distance of Cape Jones, the coast is unprotected and bold.

The eastern slore-line of James Bay is generally low, and the waters of the bay are very shallow and dotted far out with rocky islands and bouldery reefs, between which there is a perfect labyrinth of channels, naviguble with small craft, but dangerous to approach with large vessels.

The north shore of the Gulf of St. Lawrence, in many places, has a Gulf of St. more or less wide interval of low land, between the shore and the rocky Lawrence plateau behind. From Seven Islands to Natashquan Point, the shore is comparatively regular and the islands few in number. To the enstward of Natashquan, as far as the Strait of Belle Isle, the const is grently indented by small bays and coves, and islands are numerous, especially between Cape Whittle and Blanc Sablon.

The peninsula of Labrador is a high, rolling platenu, which rises General eleva. somewhat abruptly, within a few miles of the coast-line, to heights tion and conbetween 1500 and 2500 feet, the latter elevation being somewhat greater than the watershed of the interior. The interior country is undulating, and is traversed by ridges of low rounded hills, that seldom rise more than 500 feet above the general surrounding level. Frum the barometer readings, taken during the season of 1894 , in conjunction with stationary barometers at Hamilton Inlet and Anticosti, the general level of the interior plateau, about the Upper Hamilton 
Kiver and Lake Michikamnu, near the central watershed, varies from 1600 feet to 1800 feet, and this may be taken us the general height of much of the interior of the peninsula. The highest part of the main interior mass is nenr the high grunite aren between the head-waters of the Peribonka, Manicuagan und Outarles rivers, flowing into tho St. Lawrence, the East Mnin and Big rivers, flowing into Hudson Bay, and the Koksoak River flowing into Ungavn Buy. The general elevation of this area exceerls 2000 feet.

Gradual slope The only portion in which the general level is attain a by a grudual townrda Jnune' Inny. slope, is the part facing James Bay, where the lnnd along the const is low, and the rise eastward towards the interior is so light that one hundred miles inland it is only about 700 feot above sea-level.

Highlnnds of the st. Lawrence.

Beyond this the land continues to rise grudually, so that Lake Mistassini is only 1300 feet aboves sen-level. As before stated, the rise from t'le coast in other places is quite rapid; and slong the St. Lawrence const there is a lnuge of high ground extending from the neighbourhood of Quebec to below the St. Joln Rivel. The larger strenms have cut deep valleys through this range. Along the Saguenay, at Cape Eternity, the hills rise almost shear 1500 feet above the river; while behind, in the Lake St. John region, few elevations exceed 1000 feet. On the Bersimis River, the high range begins about forty-five miles inland an 1 continues to about the one hundredth mile, heyond which the country is comparatively level, and somewhat lower. On the Romaine and St. John rivers, the high lands formed from a great mass of irruptive rocks, begin about twenty-five miles from the const, and are about fifty miles broad. The general level of this belt is nearly 2000 feet and many of the summits are more than 2500 feet above sea-level, while the general level of the country immediately behind them is not much over 1600 feet. H. Y. Hind* mentions similar high lands on the Moisie River, where the general level is above 1500 feet, and some of the mountain ranges are 3000 feet above sea-level.

Atlantichigh. Along the Atlantic coast, the land rises abruptly inland, almost lands. everywhere, to altitudes varying from 1000 feet to 1500 feet, from the Strnit of Belle Isle to the vicinity of Nain. To the northward of Nain the coast range is much higher, and, in the neighbourhood of Nachvak Bay, ranges of sharp, unglaciated mountains rise abruptly from the sea to heights varying from 2500 feet to 4000 feet; while farther north they are reported to culminate in peaks of 6000 feet, a few miles inland. With a slight decrease in height, this range con-

*Explorations in Iabrador, vol. 1, chap. ix. 
tinues northward to the barren islands at Cape Chidloy. This mountnin range appenrs to be confined to the const region and probably is under fifty miles in width, the country on the western side sloping rapidly down to the level of tho interior plateau. About Unguva Bay, the general level of the plntenu is probubly somewhat under 1000 feet, nud the land rises gradually towards the interior. Little or nothing is known definitely of the grent northern aren between Unguva nnd Hudson bnys, but, from observations by Dr. R. Bell, made nlong the conste, the land appears to rise rapidly for 1000 feet, and then inore gradually to elevations between 1500 and 2000 feet. From information obtained from the Kskimo at Ungavn, there would seem to be $n$ low traet of country extending west warl from Hope's Advance towards Mosquito Bay on the Hudson Bay const, and also another aren of compurntively low country westwarl of the Leaf Lakes and of the Koksoak River valley.

The land fronting the Hudson Bay const, as far south as Cape Jones, Elevation of renches the 1000 fiet level within a short distnnce from the sen, land fronting und then rises yuickly to a general level between 1500 and 2000 feet, the latter being the maximum of elevation in this region, as do. termined by the few explorations in this portion of the peninsula. The gradual rise from the seaboard of the country to the east and south-east of James Bay, has already been mentioned.

To sum up the foregoing statements of levels, - the interior of the Summary of peninsula is almost flat, so that in an area of 200,000 square miles, elevation. there is not a difference of general level of more than 300 or 400 feet, and the highest general level of the interior is under 2500 feet. A belt of land somewhat higher than the general interior follows the St. Lawrence coast, a short distance inland. The northern half of the Atlantic const rises in a chain of mountains, considerably higher than any other portion of the peninsula. Along the northern and western coasts there is no evidence yet obtained to show the existence of a coastal ridge, but rather a probability that the general elevation increases towards the interior.

Like the other portions of northern Canada underlain by glacinted Lakes. Archrean rocks, the interior of the Labrador Peninsula is covered with myriads of lakes, that occupy, at a moderate estimate, at least onefourth of the total area. 'In size, these vary from sinall narrow ponds, to lakes with surfaces hundreds of square miles in extent. Great Mistassini and Michikamau lakes have areas considerably exceeding 500 square miles. Among those of which the area is between 200 and 500 square miles, may be mentioned Manouan Lake, on a tribu- 
tary of the Peribonka River, Pletipi Lake, at the head of the Outardes River, the Manicuagan lakes, on the headwaters of the river of the same name; all sending their waters into the St. Lawrence. Discharying into the Atlantic are Winokapau, Petitsikapau, Ashuanipi and Attikonak lakes on the Hamilton River, and Grand Lake on the Northwest River, which also drains Lake Michikamau. On the rivers discharging northward, Lake Kaniapiskau is the only one yet partly explored, but reference to the map will show a number of large lakes on the various tributaries of the Koksoak and George rivers, which have been located from information derived from Hudson's Bay Company employees and Indians.

Western watershed

On the western watershed, Clearwater Lake is one of several large lakes lying in an area between the sources of the Stillwater branch of the Koksoak River, and the Nastapoika, Clearwater, Little and Great Whale rivers flowing into Hudson Bay; all of which rise and flow through a number of large unexplored lakes.

Lake Nichicun is near the headwaters of the Big River and is drained by that stream. The Mistassini lakes discharge into the Rupert River, while the Nottoway River, which aischarges into the southern part of Janues Bay, drains, among others, lakes Waswanipi and Chibougamoo.

Lakeless area. Besides the lakes mentioned, there are hundreds having a surface area between 20 square miles and 10.0 square miles, while smaller lakes are numberless. The only portion of Labrador not thickly covered with lakes, is the low country extending inland for aloout 100 miles from the east const of James Bay. This area has been covered with a deep mantle of marine sands and clays, which has filled up the inequalities of the surface, and prevented the formation of lakes ; it is covered instead by a net-work of small streans, with deep channels cut out of the stratified drift.

Formation of lakes.
The lakes, except the largest, are usually confined in the shallow valleys between low rocky ridges, by barriers of drift, and in consequence their depth is not great, seldom exceeding fifty feet, while many of them are under twenty feet deep. Mistassini and Michikamau lakes, occupying ancient basins, in which Cambrian rocks were deposited, are among the exceptions, the former having a depth of over 400 feet, while that of the latter is said, by the Indians to exceed 250 feet. Lake Winokapau, in the valley of the Hamilton River, and Lake Mouchalagan on the Manicuagan River, are other exceptions, the former being over 400 feet deep, and the latter 650 feet deep, but, as will be explained further on, these and Grand Lake, on the Northwest River, differ from the ordinary lakes in their manner of formation. 
It follows, from the great number of lakes, that the country Great depths must be covered with a perfect network of streams discharging them. The discharges and lakes interlock so closely that, with a kno:vledge of the country, it is possil le to travel with canoes in any direction, the longest portages never exceeding two or three miles.

There are four principal watersheds to the peninsula : of these the Rivers. southern is the smallest, its rivers rarely exceeding 300 miles in length; the most important are the Saguenay and its branches, Bersimis, Outardes, Manicuagan, Moisie, Romaine, Natashquan and St. Augustine. The eastern watershed drains chiefly into Hamilton Inlet, three large rivers flowing into its head. Of these the Hamilton River is much the largest, taking its rise near the middle of the peninsula and draining an area extending from latitude $52^{\circ}$ to latitude $54^{\circ}$ covering seven degrees of longitude. Iis longest branch rises nearly 600 miles from its mouth. The other rivers of Hamilton Inlet are the Northwest and Kenamou, the former draining a large area to the north of the Hamilton River, the latter flowing in from the south-west. Apart from these three large streams, no other rivers of inportance are f und along the Atlantic coast, on account of the high lands of the coast cutting off the drainage of the interior and forcing it to flow northward into Ungava Bay.

The Koksoak River is the largest stream flowing northward, and is Koksoak probably the largest river of Labrador. Besides the main stream, ther $e$ River. are a half dozen tributaries, each of which drains an important basin. The longest branch flows out of the northern end of Summit Lake, on the 53rd parallel of latitude, while a branch of the Manicuagan River flows out of the southern end of the same lake, thus connecting by water the Gulf of St. Lawrence with Ungava Bay. The total area drained by this river and its tributaries is about 60,000 square miles. The George River, is another great stream which rises in large lakes close to Lake Petitsikapau on the Hamilton River, and drains a wide area westward of the Atlantic coast range. The Whale River is a smaller strean lying between the George and Koksoak rivers.

The western drainage basin is the greatest in Labrador and is emptied Western by large rivers, that rise far inland, close to the head-waters of the rivers. Koksoak and Saguenay rivers. Proceeding from the northward, the larger rivers flowing into Hudson Bay are:-The Nastapoka which flows out of several large lakes to the eastward of Clearwater Lake and near the head of the Stillwater branch of the Koksoak River; the Little and Great Whale rivers, that rise close to the western branches of the Koksoak ; the Big River which rises in the mountainous are 1 south 
and east of the head of the East Main River, in about latitude $52^{\circ}$, and close to the sources of the Peribonka, Manicuagan and Outardes rivers tributaries of the St. Lawrence. From its source the Big River flows northward nearly one hundred and fifty miles, passing through Lake Nichicun, and then turns westward four hundred miles, emptying into James Bay, near latitude $54^{\circ}$

The East Main River takes its rise in a number of lakes close to Lake Nichicun and flows nearly west, discharging into James Bay a short distance north of latitude $52^{\circ}$. The Rupert River forms the discharge of the Mistassini lakes, and, having such large reservoirs at its head, is not subject to the same fluctuations of volume, as the other rivers. It empties into Rupert Bay close to the mouth of the Nottoway River, which drains a wide area to the south-east of Hudson Bay, and rises in a number of large lakes close to the height-of-land dividing it from the St. Maurice River, which joins the St. Lawrence at Three Rivers.

Ancient river

The channels of most of the rivers of Labrador are of very ancient channels. origin, apparently dating back to a period before the deposition of the Cambrian rocks. These valleys are cut deep into the general level of the plateau, their depth and length apparently depending on the volume of water carried, and thus showing that they have been mainly formed by normal denudation.

The larger rivers flowing southward, have deep valleys cut through the highlands of the coast region, and the streams are often from 500 feet to 1000 feet below the general level of the surrounding country. The heads of these valleys are from one hundred to three hundred miles from their mouths; and at their upper ends the rivers descend from the level of the interior in a succession of heavy falls, through narrow gorges where processes of erosion are at present extending and deepening the valleys. This erosion is, however, so exceedingly slow, that the change in the heads of the valley, since glacial times, has been practically nothing, owing no doubt to the hardnese and resistance to weathering of the Archiean rocks in which they are cut. The gorge of the Saguenay, with its almost vertical walls rising 1500 feet above the surface of the water, and its great depth of more than 800 feet in places, is an excellent example of one of these ancient river-valleys. That of the Hamilton River, which is cut back from the head of Hamilton Inlet for nearly three hundred miles, and of which the depth is from 700 feet to 1200 feet below the general level of the surrounding country, is another fine example of river erosion. The rivers occupying smaller valleys, are all of the same type. The East Main and Rupert rivers, flowing as they do on the gradual slope towards James 
Bay, where the marine deposits of sand and clay are found inland about one hundred miles, have not the marked valleys found elsewhere, but descend in a number of steps, where they have either cut narrow gorges out of soft Huronian schists, or fall directly over granitic ledges. The ancient valleys of these streams appear to have been filled up during the deposition of these marine beds, and the present river-courses are of post-glacial origin.

Before entering the ancient valleys above described, all the rivers Newchannels. in central Labrador flow almost on the surface of the country, and are broken into chairs of lakes often formed by dains of glacial drift, which in other places form low ridges that divide the streams into different chalınels. These channels wander about on the lower levels of the interior country in a most bewildering manner, and render travel without a guide excessively difficult.

\section{Climate.}

The climate of Labrador ranges from cold temperate, on the southern coasts, to arctic on Hudson Strait and the high lands of the northern Climate along the coasts. interior, and is generally so rigorous that it is very doubtful if the country will ever be fit for agriculture north of latitude $51^{\circ}$, except on the low grounds near the coast. Along the east coast of James Bay, good crops of potatoes and other roots are grown as far north as Fort George--about latitude $54^{\circ}$-while on thie Atlantic coast of the peninsula, about the head of Hamilton Inlet, similar crops are easily cul. tivated. On the outer coast the climate is more rigorous, and appears to be much affected by the northern current, with its numerous floating icebergs, which lowers the mean temperature and renders the rowth of root crops slow and uncertain at Rigolet in latitude $54^{\circ}$. Garden vegetables are, however, grown a.c Nain in latitude $56^{\circ} 30^{\prime}$; but extra precautions are taken with them, such as the building of walls to protect them from the east wind, and covers put over them when in danger from summer frost. At Fort Chimo, near the mouth of the Koksoak River in latitude $58^{\circ}$, with care small patches of turnips, lettuce and radishes are grown.

In the interior, at the Hudson Bay's post of Mistassini, in latitude Climate of the $50^{\circ} 30^{\prime}$, a crop of potatoes is raised annually, but, owing to the shortness of the season and the prevalence of summer frosts, they rarely mature without the tops being froze?. No other vegetables are cultivated here at present. At Nichicun attempts are made to grow potatoes, but they have always proved more or less frilures, owing to frosts in July and August. It will thus be seen that the prospects of the 
Absence of grass.

Summer season.

Winter season.

settlement of the central portion of Labrador, for purposes of agriculture, are by no means bright; and, if settlements are made for other purposes, the inhabitants will have to depend largely on more sonthern localities for their vegetable food. Owing to the absence of grass plains, and to the mantle of moss and lichens that covers the surface of the ground almost everywhere, there is little likelihood that it will ever be a grazing district. The ligh lands of the interior have only two seasons, winter and summer. The summer season begins almost simultaneously throughout the interior, and the jump from winter into summer occurs as a rule during the first two weeks of June, when the snow disappears, and the ice leaves the rivers and lakes, except the largest, where it often remains until July. With the disappearance of the snow and ice, the temperature during the day rapidly increases, and the leaves are almost immediately put forth by trees and bushes. During 1894, frosts were of almost nightly occurrence until June 28th, when a thin sheet of ice was formed in the vessels about camp, and slight flurries of snow fell in the morning. After this date no frost was noted, but, thermometers having unfortunately been broken, the exact temperature could not be taken. To the north of latitnde $52^{\circ}$, snow falls and ice begins to form in the small lakes about the middle of September. From early in October the snow remains permanently, and all the smaller lakes are solidly frozen, so that, for the greater part of the interior platean, there is at most only three months of summer. The temperature during the winter season is often very low on the interior high lands, away from the influence of the sea. The coldest months are December, January and February, and the following readings of thermometers taken at Mistassini* in 1885 , will give an idea of the temperature of that region, which appears to be somewhat higher than about Nichicun and the upper Hamilton River.

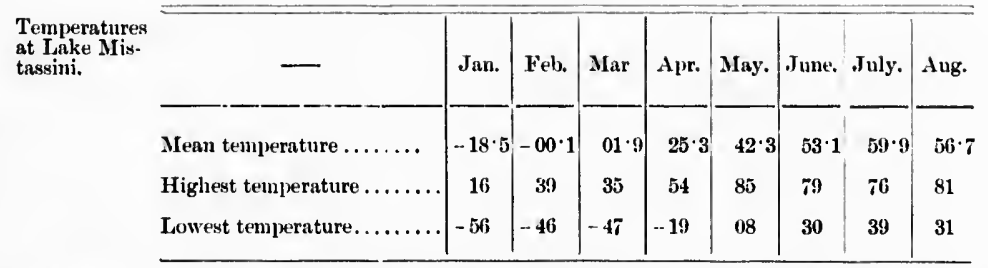

Great thickness of ice.

According to reports of the Indians, the ice in Lake Michikamau is 7 feet 6 inches thick on an average, and the amount of continuous frost to form such a thickness must be very great. The ice in Lake Winokapau, in the deep valley of the Hamilton River, was from actual

*Annual Report, Geological Survey of Canada, vol. I. (N.S.), 1885, p. 16 D. 
measurement found to be 4 feet 9 inches. From the journal kept at the Lake Winopost on this lake, between 1866 and 1874 , the first snow generally fell kapau. about September 20th and continued until June, the latest record being June 10th. The lowest temperature :ecorded was $55^{\circ}$ below zero. Geese and summer birds arrived on or about May 10th. From the journals at Northwest River post, the lowest temperature recorded from 1867 to 1893 , was $53^{\circ}$ below zero. There are several observations of $45^{\circ}$ Hanilton below zero, which appears to be the minimum winter temperature of Inlet. most years. At Rigolet, where the temperature is moderated by the open sea, the thermometer rarely registers $40^{\circ}$ below zero. At Fort Chimo, where the open sea is not far distant, $45^{\circ}$ below zero is sair \% l'ort Chimo. be the lowest temperature registered. The summer temperature of itie Atlantic coast region is considerably lower than inland or along the western coast. As a rule the thermometer in the interior-north of Mistassini-rarely rises above $80^{\circ}$ during the middle of the day on more than a few days during the summer season.

The temperature depends greatly on the direction of the winds. Winds. During the summer, south and south-west winds prevail in the interior, and are accompanied by higher temperature and often overcast sky, with drizzling rain. 'I'he west and north-west winds bring clear weather with lowering temperature, especially during the winter season. North and north-enst winds are usually accompanied by heavy storms of rain and snow, with cold moist atmosphere. East and south east winds, as a rule, blow with clear pleasant weather.

The precipitation of moisture over the interior area is not great. Rain. During the winter the snowfall varies from three to six feet, and the greater part of it descends during the periods of north or north-east wind, which are not common; the north-west wind, blowing at least three-quarters of the time during the winter season, is accompanied by a bright clear atmosphere. During the summer season the precipitation, if not great, is constant, as a day rarely passes without drizzle, or thunder showers, which lower the temperatue.e.

At Northwest Kiver, the head of Haniltion Inlet freezes completely Bays on over between the 1st and 15th of December, and opens again between Atlantic coast May 15th and June 15th. Snow falls early in October, and from that date to about the first week in May, the latest record being July 2nd. At Rigolet, the outer part of Hamilton Inlet rarely or never freez's solid before the middle of January, and in some winters does not close at all. This is due to the strong currents in this part of the inlet. Sandwich Bay, nearly one hundred miles farther south, generally freezes over in the end of December, and the same time may be taken as that of the closing of most of the larger fiords of the 
Snow. Atlantic coast. About Fort Chimo, the lower grounds are permanently covered with snow by the 1st of December, this covering remaining until the 10th of June. The higher hills retain snow until the last of August, and by the middle of September snow again covers the tops of the distant high hills. *

Soil.

Character of soil on the Archeanarea.
The soil of the greater part of the peninsula is derived from the underlying Archran rocks, and is mostly in the form of glacial till, mixed with boulders of various sizes. The till is a mixture of sand and clay in which the former greatly predominates. In many large areas which have been traversed by fire, much of the vegetable matter of the surface has been destroyed, and the remaining soil supports only a scant growth of small trees. Along the sides of the rivervalleys the drift has been re-arranged and inixed with sediments. Here the soil, though generally light and sandy, is richer than the unmodified till; and the size and variety of trees growing on it are Marine consequently greater. Within the limits of the marine deposits, about deposits.

Cambrian débris. the margins of the peninsula, the stratified sands are underlain by bedded clays, and as the coast is approached, the overlying sands thin out, leaving the clays near the surface, thus producing a light roil with a heavy subsoil, on which the vegetation is much better than anywhere else, except on the lower banks and islands in the rivers near the coast, where the sands and clays are topped with deposits of alluvium. The soil covering the areas of Cambrian rocks, being made up of the débris of limestone, shale, and other rocks of this formation, is of a heaviel nature than that formed from the Archean rocks; and the change from one to the other is marked by the better growth of trees on the former.

\section{Trees and Otuer Plants.}

Various trees. The southern half of the Labrador Peninsula is included in the sub-arctic forest belt, as described by Prof. Macoun. $\dagger$ Nine species of trees may be said to constitute the whole arborescent flora of this region. These species are:-Betula papyrifera, Michx., Populus tremuloides, Michx., Populus balsamifera, Linn., Thuya occidentalis,

"Annual Report U. S. Bureau of Ethnology, 1889 90, -Ethnology of the Ungava District. L. M. Turner, p. 172.

t'The Forest Trees of Canada. John Macoun.-Trans. Royal Soc. Canada, Sec. iv., 1894, pp. 5-7. 
Linn., Pinus Banksiana, Iam., Picea alba, Link., Picea niyra, Link., Abies balsamea, Marsh, and Larix Americana, Michx.

The distribution of the forest areas and the range of the various Distribution. trees depend on several factors, anong which may be mentioned, position as regards latitude, height above sea-level, distance from sea-coast, and character of the soil, all of which are important.

The forest is continuous over the southern part of the peninsula to Forest areas. between latitudes $52^{\circ}$ and $54^{\circ}$, the only exceptions being the summits of rocky hills and the outer islands of the Atlantic coast. To the northward of latiturle $53^{\circ}$, the higher hills are treeless and the size and number of the barren areas rapidly increase. In latitude $55^{\circ}$, more Barren than half the surface of the country is treeless, woods being only found grounds. about the nargins of small lakes and in the valleys of the rivers. Trees also decrease in size until, on the southern shores of Ungava Bay, they disappear altogether. The Leaf River, which empties into the bay a few miles north of the wouth of the Koksoak River, is the northern limit of forest trees on the west side of Ungava Bay.

Along the enst coast of Hudson Bay, Dr. Bell found trees growing a few miles beyond the north end of Richmond Gulf.*

In the neighbourhood of Clearwater Lake, the writer found many clumps of black spruce and larch, and, according to Indian reports, small patches extend to the Nastapoka River in latitude $57^{\circ}$. So that a line drawn a little south of west, from the mouth of the Leaf River Northern tree to the moutl of the Nastapoka River on Hudson Bay, would give a limit. close approximation to the northern tree limit of western Labrador.

The tree-line skirts the southern shore of Ungava Bay and comes Atlantic close to the mouth of the George River, from which it turns south-south- ${ }^{\text {const. }}$ east, skirting the western foot-hills of the Atlantic coast range, which is quite treeless, southward to the neighbourhood of Hebron, in latitude $58^{\circ}$, where trees are again found in protected valleys at the heads of the inner bays of the coast. At Davis Inlet, in latitude $56^{\circ}$, trees grow on the coast and high up on the hills, the barren grounds being confined to the islands and headlands, which remain treeless to the southward of the mouth of Hamilton Inlet. These barren islands and bare headlands of the outer coast, along with the small size of the trees on the lowlands, have caused a false impression to be held regarding much of the Atlantic coast, which from Hamilton Inlet southward is well timbered about the heads of the larger bays and on the lowlands of the small river-valleys.

"Reprort of Progress, Geol. Surv. Can., 1877-78, p. 256. 
The distribution of each of the several species of trees depends on conditions similar to those affecting the forest areas in general.

Distribution of white birch.

Northern limits.

Distribution of aspen.
Betula papyrifera, Michx. (White, Paper, or Canoe Birch) is found every where throughout the southern portion of the peninsula. Except in the district to the south-west of Iake Mistassini, drained by the Nottoway River, and on the southern watershed, the trees du not grow sufficiently large or straight to afford bark for canne building, and the Indians of the more northern portions have to depend upon bark imported by the Hudson's Bay Company for their canoes. About Lake Nichicun and on the upper waters of the Hamilton River, the largest trees rarely exceed eight inches in dianeter. The trees are. found in thickets of second-growth, on the hillsides which have been traversed by fire; they also grow sparingly in unburnt portions. Northward of Nichicun, the white birch becomes rapidly smaller and along the upper Koksoak River does not average three inches in diameter. At Cumbrian Lake, where the limestones are encountsied and the river-valley is deep and protracted, the size of the trees improves, and birches six inches in diameter are not uncommon. Below the junction of the Swampy-bay River, the trees again become small, and finally die out on the Koksoak River a few miles above Fort Chimo. On the Hudson Buy side, the northern linit of white birch is near the mouth of the Great Whale River, while inland it is found, in small straggling clumps, at the head-waters of the south branch of that river. About Hamilton Inlet, birch is common, and, at the head of the inlet, trees up to ten inches in diameter are not uncommon.

Populus tremuloides, Mich. (Aspen). The range of this tree depends, to a great extent, on the nature of the soil. In the southeri portion of the peninsula, it is found as a second growth along with the white birch, and also in clumps in the original forest. It appears to be most plentiful on the western half of the peninsula, where it grows most abundantly on the unmodified glacial till of the drift ridges. At Lake Mistassini, this tree is abundant and is often ten or twelve inches in diameter about the southern portion of the lake. Along the upper East Main River, only small clumps of bent and twisted trees are seen, while about Nichicun it is exceedingly rare. To the northward of Nichicun, this tree was not seen along the route followed to Ungava Bay. On the Hudson Bay coast, the neighbourhood of Cape Jones is the northern limit of the aspen; while inland it is found on the portage-route, between the lower and upper parts of the Big River, in latitude $54^{\circ}$. About the head of Hamilton Inlet, and along the river helow the Grand Falls, clumps of aspen are frequently 
met witl. But above the Grand Falls this tree was not seen anywhere on the waters of the Hamilton River, its first occurrence on the route southward being near the portage-route lending to the Romaine River from Lake Attikonak. Along the Romaine River, it soon becomes common as the stream is descencled. On the Manieuagan River aspen is found in the deep river-valley to beyond latitude $52^{\circ}$, but does not grow on the surrounding table-land.

Populus balsamifera, Linn. (Balsam Poplar) is met with farthernorth Distribution than the aspen; but it appears to contine itself to the heavy clay soil of hisam of the river-valleys, or to the modified drift of the Cumbrian areas. It is met with along the Big and Eust Main rivers, flowing into Hudson Bay, and its northern limit on this side of the peninsula is the Bishop Roggan River, the next stream nortl of the Big River. Along the rivers of this const, bulsam poplar was only met with for about one hundred miles inland from the const, where its limit was that of the stratified marine clays of the river-valleys. On the upper East Main River, it was nowhere seen, and it does not appear to grow northward of Lake Mistassini in the western interior. After passing through an area of several hundrerl miles from Mistassini to Eaton Cañon, on the Koksonk River, balsam poplar is again found growing in the valley of that river and continues to be found at intervals, to within twenty-five miles of Fort Chimo. At the head of Cainbrian Lake, large clumps of Northern trees of this species, ten inches in diameter, were observerl growing on limit. the low terraces, but elsewhere they were small and straggling. On the lower Hamilton River, balsam poplar is common. Above the Grand Falls it is not found along the river, for upwards of a hundred miles, until the Cambrian area about Birch Lake is reached, when small trees of this species become common, and continue along the Ashuanipi Branch to the end of survey. On the Attikonak Branch, a few small trees were noted between Sandy Lake and the height-of-land to the sonthward.

Thaya occidentalis, Linn. (Cedar) hardly enters the southern limits Distr ibution of the peninsula. It occurs just south of the mouth of the Rupert of $c$ tar. River, at the foot of James Bay, and does not cross that stream in the eastern course of its northern limit. It is only found about the southwestern bays of Mistassini Lake, from which it extends south-east, crossing the St. Lawrence to the westward of Seven Islands. No cedar trees were seen along the Manicuagan River from its mouth up. ward.

Pinus Banksiana, Lam. (Banksian Pine, Jack Pine, Cypress) is Distribution limited in its extension by an eastern as well as a northern boundary. of Banksiau 
It grows freely over the western half of the peninsula, and appears to prefer the dry, sandy drift ridges and rocky hills, where it is oiten found along with hlack spruce, as a second growth, covering ureas

Nortliern limit. devistated by fire. Its northern limit is the south branch of the Great Whale River, south of which it oceurs abundantly to the shores of the St. Lawrence, but does not come quite to the const on Hudson or James Bay, probably on account of the shore being generally low and swampy. Inland, it is met with abundantly, along the Eust Main vastern limit. River, to the Iong Portnge Creek, near its head, in about longitude $71^{\circ} \mathrm{W}$. Here a line running nearly north and soutl terminates the enstern extension of the Banksinn pine. About Nichicun only a few small clumps are found to the westward of the lake, and it is unknown to the Indians to the eastward. In the southern extension of its enstern limit, the line runs somewhat east of south and renches the St. Lawrence in the neighbourlsood of the mouth of the Moisie River, being every here common along the main brunch of the Municuagan River.

1)istribution of white sproues.

Northern limit.
Picea albu, Link. (White Spruce) is found throughlout the wooc. ed area of the peninsula, but it is not everywhere common, and there are several areas where it is rarely found. Its distribution is but little affected by climate or by height above sea level; it appears to depend nitogether on the soil. North of the southern watershed, it is confined to the areas of re-arranged clrift of the river-valleys and marine deposits ulong the const, or to the heavier drift of the Cambrian areas of the interior. Along the western coast, the interior linit of this tree, on the Eist Main and other rivers flowing into Hud. sun Bay, eoincides closely with the margin of the marine deposits, and consequently does not extend one hundred and fifty miles eastward from that coast. From Lake Mistassini, along the route to Nichicun, no trees of this species were met with, but it is said to grow sparingly about the latter place. A few small trees were observed on terraces between Nichicun and Lake Kaniapiskau. Along the upper Koksoak River, small trees were seen occasionally on its terraced banks to Eaton Cañon. Below this place, the number of trees and their size increased rapidly in the river-valley, and from here to the forks of the Stillwater many of them exceeded eighteen inches in diameter three feet from the ground and were over fifty feet in height. Below the Stillwiter, their size rapidly decreased, and the trees died out near the mouth of the Koksoak River, along with the black spruce and larch, of which the northern limit is about co-terminous with that of the white spruce. About Hamilton Inlet, white spruce is abundant on the lowlands, and at the mouths of the Kenamou and Hamilton 
rivers many large sticks have been tnken out for spars und masts for Giod timler. schooners. Here, and along the Hanilton River valley, where unburnt, this tree often exceeds eighteen inches in clia:neter, and grows sufficiently tall to allow of three good twelve-foot logs being cut out of a single tree. Above the Grand Falls, white spruce is found aleng the river banks, but is generally small and scattered until the Cambrian aren of the upper waters is reached, when it becomes more abundant and grows well up the hillsides. Many of the trees of this region are very stout at their bases, but being short and branching would make poor lumber. To the southward of the Cambrian area, on the Attikonak Branch and the upper Romaine River, very fow trees of this species are seen until the latter stream enters its ancient valley, when they beconie more abundant. They are founcl everywhere in the valley to the St. Lawrence. In the valley of the Manicuagan River, trees of this species attain a large size and are very abundant to Lake Mouchalagun, nhove which they grndually become fewer and smaller, and die out near the mouth of the Attikopi liver.

Piepa nigra, Link. (Bluck Spruce) is the most abundant tree of Distribution Labrador and probably constitutes over ninety per cent of the forest. of lilack It grows freely on the sandy soil which oovers the great Archwan areas, and thrives as well on the dry hills as in the wet swampy country between the ridges. On the southern watershed the growth is very thick everywhere, so much so that the trees rarely rench a large size. To the northward, about the edge of the semi-barrens, the growth on the uplands is less rank, the trees there being in open glades, where they spread out with large branches resembling the white spruce. The northern limit of the black spruce is that of the forest belt; it and larch being the last trees met with before entering the barrens.

Abies balsamea, Miller. (Balsam Fir, or Spruce,) is another species Distrilution that grows only on suitable soil. It is found nearly to the edge of of balsam fir. the barren grounds. Throughout the wooded regions it grows more or less plentifully about the margins of the larger streams and lakes, apparently preferring soil containing considerable moisture and alluvium. Northward of the southern watershed, it is rarely found away from the edges of rivers and large lakes, and is wanting along the portage-routes connecting the larger streams. On the Hudson Bay coast, its northern limit is near the Great Whale River. On the Northern Koksoak River a few trees were seen below the junction of the Still- limit. water. Along the Hamilton River it grows everywhere and was also found growing about the shores of Lake Michikamau. 
Dintribution of lareh.

Destruction by naw-Hy.

Furentareancof commeroinl value.

Forest fires.

Causes of fires.
Lari, Americana, Miehx. (Jareh, Tunaruck, 'Juniper'), is probably the hardiest tree of the sub-arctic forest belt; it giows averywhere throughout the Labrudor Peninsula, and is probnbly next in abundance to the black spruce. 'Mliroughout the interior it is fomml growing in all the cold swamps, and is always tho largest tree in the vicinity. Along the northern margin of the forest, the larch continues as $u$ tree to the very edge, where the blnck spiuce is ciwarfed to n mere slirub. 'The larch of the southeris region lins been ulmost totally destroyed by the ruviges of the inprorted, Europenn larch saw-lly (Jimalus Erirlisonii). The present runge of this rest extends northwurd flom Inke St. John to beyond Lake Mistassini, and nppears to be yenily spreading morthwurd and eastwaril, but lias not yet restcherl the Sit. Jolun or Ronuine rivery flowing into the Gulf of St. Lawrence.

Arens of forest of sutlicient size, with tres large enough for commercial purposes, wre confined to tho southern watersheil and to the lower courses of the strenms flowing into the Atlantic or Iludson Bay. It is very doubtful if such arens oecur along these coasts to tho north of latituile $54^{\circ}$. Nuch of the timber of the more southern regions is not of the best and *nlil afforil only spruce deals, while the grenter

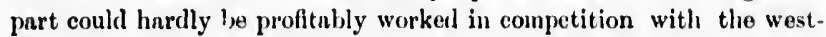
orn pine; but the time will probably come when the trees of the unoro favournble portions of Labrador will be protitably worked into lumber, especially if tho smaller growths are cut at the sane time for the manufacture of paper pulp.

At least one half of the forest aren of the interior lias been totally destroyed by fire within the past twenty-five or thirty yenrs. These fires are of annual occurrence and often burn throughout the entire summer, destroying thousands of squure niles of valunble timber, to the south of the central watershed. The regions thus devastated remuin barren for many years, especially towarts the northern limits, and the second growth of black spruce, Banksian pine, aspen and whito birch is never as good or as large as the original forest. These fires are clue to various causes, but the majority of them can be truced to the Indians, who start then either through carelessness or intentionally. The Nasenupee Indians of the semi-barrens signal one another by smoke male by burning the whito lichens that cover most of the ground in the interior, and these signals cause many of the fires. The southern Indians signal in a similar manner, but do not practice it to such an extent as their northern brethern, having found that they are rapilly destroying their hunting grounds. Careless cainp fires in dry sensons are another common cause of these forest fires, and many of those ascribad to lightning, if closely traced 
woukl bo found to have been set by wnudering Indians, who are only cureful on their own huntiug grounds. From what is seen on the explured routes of the southern watershed, it would nppear thut at lenst one half of the forest has been removed hy this cause.

The grentest fire of modern times oceurred in 1870 or $187 \mathrm{l}$, and lirent file of swept the country south of the height-of-Innd, from the St. Mnurice INini-il. to beyoud the Romaine River. The second growth is just heginning to cover up the traces of this grent conflagration, which ruined the pioneers of Iake st. John, and it will he years before the country is generally again well wooded. The upper llomaine river-valley has Rosmine been totully burnt over within the last ten years, nnd the margin of liver. this great burnt aren has been extended south word during the -ummers of 1893 and 1894 , so that now practicully no green woods exist along the conrse of this river from the St. Lawrence to its source. The country surrounding the Hnmilton River is in a similar state ; except Hamilson patches of original forest, nlong the lower part of the river-valley ikiver. uucl about Hamiltou Inlet, only blackenerl stuups or a small second growth are seen nlong its course, with an occasional onsis of large green wool to break the monotony. In this region grent fires oecur unnually; that of I893 covered hundreds of square miles of the tableland between the Humilton and Northwest rivers. Similar remarks upply to the forests of the western watershed, more than half of which hnve been burnt.

Thuroughout the forest belt, the lowlands fringing the strenms and Willow. lakes are covered with thickets of willows and alders. As the scmi-barrens are appronched, the arens covered by these shrubs become more extensive, and they not only form wicle murgins along the rivers and shores of the likes, but with dwarf birches occupy much of the open glades. The willows and birches grow on the sides of the hills, above the tree line, where they form low thickets exceedingly ifficult to pass through. Beyond the limits of the true forest, similar thickets of Arctic willows and birches are found on the low grounds, but on the more elevated lands they only grow a few inches nbove the surface. In the southern region, the undergrowth in the wooderl areas is chiefly Labmdor ten (Ledmm lutifolium) and "laurel" (Kralmia gleuen), which grow in tangled inasses, from two to four feet high, and are very difficult to travel through. In the semi-barrens this undergrowth dies out, and travel across country is much ensier in consequence. In the southern regions the ground is usually covered to a considerable depth with splungnum, which northwaid of $51^{\circ}$ is grudually replaced by the white lichens or reindeer nosses (Cladonia), which grow freely everywhere throughout the semi-barren and barren regions. 
Snall fruits. The distribution of small fruits and berries is of some importance and may he recorded here, although they are included in the plant list of Appendix VI.

Cherry. Prunus P'ennsylvanica, Linn. (Wild cherry) is found in burnt areas northward throughout the interior to about latitude $55^{\circ}$, where it grows in small bushes, rarely more than four feet high.

Bake-apple. Rubus chamremorus, Linn. (Cloudberry, Bake-apple, Yellow-berry) is found in the swamps everywhere throughout Labrador to beyond the tree limit, and forms an important article of food for the Indians.

Arctic rasp- Rubus arcticus, Linn. (Arctic raspberry, Dewberry, Eye-berry) berry. grows in the opens, alung the banks of northern streams, and is especially abundant on the islands along the east coast of Hudson Bay. It is a much larger fruit, and has a more delicate wine-flavour than the next species.

Dewberry. Rubus triflorus, Richards (Dewberry, Eye-berry) is found along the banks of streams and on the edge of woods northward from the St. Lawrence to about latitude $54^{\circ}$, where it occurs rarely on the banks of the upper Hamilton River and about Lake Nichicun.

Raspberry. Rubus strigosus, Michx. (Red raspberry) is limited to about the same range as the last species, being found in burnt woods as far north as latitude $54^{\circ}$.

strawberry. Fragaria Virginiana, Duchesne (Wild strawberry) is not abundant in the interior, owing to the absence of grassy glades, or opens; it is only found on grassy banks, at the ends of well-used portages, or in the clearings about the Hudson's Bay Company's forts, as at Mistassini, Nichicun and the abandoned Fort Nascaupee, on the Hamilton River. Along the coast of Hudson Bay, it is found abundantly on the islands, to beyond Fort George, in latitude $54^{\circ}$.

Indian pear. Amelanclier Canudensis, Torr. and Gray (June-berry, Indian pear). Of this specic 3 both the oblongifolia and oligocarpa varieties are found, northward, to the Big and Hamilton rivers. The latter variety is most common, and is much inferior in fruit to the rarer variety. It grows in glades, generally in swampy ground. The first variety is confined to the burnt areas and hillsides.

Blueberries. Several species of Vaccinium are found abundantly throughout the peninsula, growing on the burnt districts of the south, and in the open country of the semi-barren and barren lands.

Vaccinium Pennsylvanicum, Gray (Blueberry), is very abundant throughout the southern region, where it grows profusely on the 
extensive burnt lands, as far north as the East Main and Hamilton rivers, and is abundant at Nichicun, where the fruit is often destroyed by summer frosts. It was found abundantly along the Koksoak River, nearly to the Stillwater Branch. On the Atlantic coast, it has been found northward to the vicinity of Nain, while on the Hudson Bay coast, it reaches nearly to the (rreat Whale River. Its fruit is used largely by the Indians, who dinring the later summer months subsist largely upon it. It is eaten both raw and in the form of jam, and, mixed with a sinall proportion of flour, it is made into bread or cake.

Vaccinium uliginosum, Linn. (Duck-berry) is a more northern form, Duck-berry. which, on the edge of the semi-barrens, largely replaces the last mentioned species. In the southern portions of the peninsula, it is only occasionally found on the banks and islands of the rivers. In the ricinity of the Hamilton and Big rivers, and northward, it is found growing profusely in the open spaces, along with V. Pennsylvanicum, and continues northward into the barrei grounds, where it occurs as a small spreading shrub, growing only two or three inches high. The fruit of this species is more acid and firmer than the southern blueberry, and is not as pleasant to the taste, especially when cooked, having then a disagreeable flavour. It is also an important article of food to the Indians and Eskimo.

Vaccinium crespitosum, Michx., is a more northern variety than the last, being found on the summits of the higher hills about the headwaters of the Hamilton River. It continues abundant to beyond the mouth of the Koksoak River.

Vaccinium Vitis-Idcea, Linn. (Cranberry, Pomme de terre) is the Cranberry. most important berry of the northern half of Labrador. South of latitude $51^{\circ}$, it is found only on the summits of barren rocky hills, or on barren islands in the larger lakes; but to the northward, as the open barren spaces increase, it soon becomes abundant, and about the Hamilton and Big rivers is very plentiful everywhere, growing on the low ridges of drift, as well as on the rocky hills. It continues to be abundant to the northward of the Koksoak River. Owing to the lasting qualities of tine fruit and its improvement by frost, large quantities are gathered annually by the inhabitants, before the ground is covered" with snow, for use during the long winter, throughout which the berries keep perfectly, and counteract the ill effects of the constant meat diet of the Indians and other inhabitants. The fruit is found in perfection, immediately after the disappearance of the snow in the spring, and continues good for several weeks, until the juices are dried up by the sun. 
Crow-berry. Empetrum nigrum, Liun. (Crowberry) is abundant throughout the semi-barren and batren regions of the peninsula, growing freely on the coast and inland. Where the various species of Vaccinium are absent, its fruit is eaten by the natives; but, as it is watery and not well flaroured, it is not esteenied as highly as the other berries. It is a favourite food of the curlew, and is eaten by geese in the early spring.

List of plants. The lists of plants contained in Appendix VI. show the distribution of the flora of the Labrador Peninsula, including different areas of the interior where collections have been made, and also the Atlantic and Hudson Bay consts.

\section{Population.}

Inhabitants.

With the exception of the white settlements along the north shore of the Gulf of St. Lawrence and on the Atlantic coast, and the few whites employed by the Hudson's Bay Company in the interior and on Fiudson Bay, the inhabitants of the Labracior Peninsula are either indians or Eskimo.

Difficulty in making a

It is very difficult $t$.s aurive at nore than a rough approximation of celisus. the numbers of Indians inlabitir; the interior, owing to their habits of roving from one Company's post to ancrier; and the consequent liability to counting the same family sevel'al tiues, if the returns are computed from the books of the various posts, which is the only available data for any exact enumeration.

Number of

From the returns given in the reports of the Department of Indian Indians. Affuirs, the Indians of the Gulf of St. Lawrence, including those of Lake St. John, numbered 1919 in 1888, and 1725 in 1893. These figures exclude 2860, under the heading of the "Nascopies of the Lower St. Lawrence," which number is the same in both returns. According to the same source, the number of Indians of Eastern Rupert Land is 4016; that of the Labrador (Canadian Interior) 1000 , and that of the Atlantic coast 4000 . The lust probably refers to the Eskimo, but is not so stated. These returns wouli! give a total native population of more than 13,000 persons, if the Indians of Eastern liupert Land are those of the east coast of Hudson Bay.

In Appendix II., page 336, of the report of the Commit:ee on the Hudson's Bay Company (1857), a return of the native population is given, compiled by the Hudson's Bay Company and others. The total number of natives trading at, and belonging to, the various posts in the Labrador Peninsula is given as 3885 persons; and this estimate, although probably somewhat ligh, is still much nearer to the native 
Indian population than that given above. The population of the St. Lawrence coast is given as 1800 persons, which agrees closely with the Departiment of Indian Affairs returns for the years 1888 and 1893.* Of the remainder, 400 belonged to posts on the Atlantio coast, where probably a number of Eskimo are included, 950 belonged to the posts of the east coast of Hudson Bay, and the balauce, 735, were attached to the posts of the interio. Since this return was made, the food resources and other conditions have changed considerably, and with them the distribution of the Indians.

In 1857 , there were seven trading posts in the interior of the pen-Changes in insula, and at present there are but three, Waswanipi, Mistassini and P'mulation. Nichicun, Fort Chimo, near the mouth of the Koksoak liver was not then opened. The policy of the Hudson's Bay Company was then to keep the Indiaus away from the coast and contact with opposition traders ; this las now been changed, and the great body of the natives travel annually to and from their hunting grounds in the interior, to the various const posts. In consequence, instead of 735 persone belonging to inland posts, at present there are not above 300 attached to these posts. The number of $\mathbf{J}$ :dians trading at Northwest River and Davis Inlet, on the Atlantic const, is about 200 persons. At Fort Climo the famine of $1892-93$ reduced the number of Indians in that district from 350 to less than 200 persons. Connected with the posts at Great Whale River, Fort George and liupert House, on Hudson Bay, the total number of Indians does not exceed 1000 persons, and probably falls considerably short of that number, so

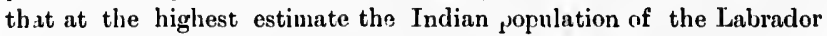
Peninsula does not exceed 3500 , and is more likely nearer 3000 .

The Eskimo inhabit the coast of the peninsula from Samilton Inlet Nimber of northward nleng the Atlantic coast to Hudsen Strait, the east Eiskinus. shore of Hurlson Bay as far south as Greai W:ale River, while a few families live on the islands of James Bay. From the mt..gre returns available, only an approximate statement of their numbers can be conipiled. In the census of Newfoundland (1891), the Eskimo ars not separated from the white populition of the Labridor coast ; but, us the number of resident whites is not above 100 persons north of liamilton Inlet, and as the Eskimo form about one-half the population of that place, from a total of 1191 persons there, and along the cuast north of Hamilton Inlet, between 900 and 1000 may be taken as Eskinn. The following estimate of the Eskimo population living on Hudson

*'The census return for $18 ! 1$ gives a total of 138 indians belonging to the posts slong the north shore of the St. Lawrence, to the eastward, and exclusive of, the Saguenay. 
Strait and the east coast of Hudson Bay was supplied by Mr. R. Gray, who was for upwards of ten years clerk at Fort Chimo, and is well acquainted with the Eskimo of Ungava Bay:-From Cape Chidley to Hope's Advance, 51 families; about Hope's Advance, 30 families ; from Stupart Bay to Cape Wolstenholme, 80 families ; from Cape Wolstenholme to Great Whale River, 80 families. The avorage Eskimo family is small and rarely exceeds five persons. Taking this as the average, the total population to the west of Cape Chidley would be 1200 persons. This estimate is probably excessive, and 1000 persons would be nearer the number, if not still above it. According to the Newfoundland census of $18^{8} 1$, the total population

Whites on Labrador coast.

Total popula. tion.

"Planters." of the Labrador coast between Blane Sablon a : Cape Chidley is 4106, including the Eskimo already referred to. Subtracting the 1000 Eskimo would leave a resident white population of 3106 greatly increased during the suminer montlss by fishermen from Newfoundland. In 1890, 10,430 men, 2076 women and 828 children from Newfoundland were so engaged, in 854 vessels.

According to the Canadian census (1891), there is a white population of 5728, scattered along the north shore of the Gulf of St. Lawrence, to the eastward, and exclusive of those living about the month of the Saguenay River, who number 2440.

To sum up, taking 3500 Irdians, 2000 Eskimo and 8800 whites, the total population of the Labrador Peninsula is 14,300, or, roughly, one person to every thirty-five square miles.

The white population along the gulf coast consists largely of French Canadians who obtain a livelihood chiefly from the fisheries, with slight help from fur hunting during the winter. On the Atlantic coast the whites, . Iorthward from the Strait of Belle Isle to Sandwich Bay, are largely English speaking, and are either immigrants from Newfoundland, or th- descendants of English fishermen formerly engaged in the salmon fishery. Northward of Sandwich Bay, the white inhabitants are, for the most part, descended from Hudson's Bay Company servants, who married Eskimo women and remained on the coast after their services had expired. They are known along the coast as "planters," and gain a fairly comfortable living from the cod and salmon fishery in the summer, and by fur hunting during the winter. They are all deeply in debt to the Hudson's Bay Company and Newfoundland fishing firms for supplies advanced. Having no capital of their own, they are compelled every pring, in order to carry on their fishing, to obtain supplies and nets from the merchants. If the season is favourable, they may be able to pay off their 
debts at its close; but, as a rule, of late years they have been going deeper and deeper into debt, owing to the scarcity of fish along the coast where they are accustomed to make their fisheries. The natives ascribe the failure of the fishery to the numerous trap-nets now used along the coast by fishermen employed by the Newfoundland merchants. The use of these nets is said to be contrary to the law of Newfoundland, but, as there is no strict government patrol of the Labrador coast, the law is practically inoperative.

At the close of the fishery, the greater number of the "planters" Winter leave their small houses on the coast, and proceeding to the heads of quarterw. the various bays, go into winter quarters in their small houses there. During the winter they are engaged hunting fur-bearing animals. These also are not so plentiful as formerly, owing probably, to the large areas burnt over, either from fires accidentally made, or set on purpose by the owners of schooners, who often fire the country along shore, so as to easily make dry firewood for future seasons.

Each "planter" has a "path," or line of traps, often extending fifty Fur humting. miles or more inland, and as these paths cannot be covered in one day, he has small "shacks," or log houses, at convenient intervals along them, where he can pass the night with some degree of confort. Some of the paths are so long that they require a week to go over and attend to the traps on the way.

During the months of April and May the planters and Eskimo are Seal hunting. engaged at the seal hunt. They kill these animals on the ice of the upper part of the inlets, by watching at their holes or cracks, and spearing them when they come to breathe or sun theinselves. Formerly the takes were large, but of late years they have been so small that many are abandoning the hunt. As soon as the ice leaves the bays, seals are taken in nets set along shore. The seals are used principally for local consumption, although some skins and a small quantity of oil are exported. The skins are used for outer winter clothing and other domestic purposes, while the fat and meat are preserved for dog food; for, as each "planter" has a team of dogs, varying in number from two to six, and as the Hudson's Bay Company keep a large number of dogs, a great quantity of seal meat is required.

Notwithstanding the decrease in the fishery, furs and seals, the planters make a much better living than many of the poorer people in cities; and, if they were to exert themselves more, and were more thrifty, they might make a comfortable and independent living. As it is, with a reasonable amount of care, thought and labour, they can procure sufficient provisions to keep their families well fed, as in the rood supply. 
fall, after the close of the commercial fishery, they can obtain an abundance of brook trout, that swarm at the mouths of all the strenms tlowing into the sen. At this time, spruce partidges are very plentiful on their migration from the coast inland, while, huter, ptarmigan and rabbits are generilly abundant. The proceeds of their fishery would easily provide them with flour and provisions, while all living inland might raise a small crop of potatoes; then, the procceds of their winter's hunt would, in most cases, be ample to supply clothes for a year, and leave a surplus. This is, unfortunately, not the case, and a number of families are often without sufficient food and clothing every year.

Misimaries. For the spiritual benefit of the whites, the Methodist church of Newfoundland has a mission stution opposite Iigolet, in charge of the Rev. Mr. Pollock, who resides there a part of the time; the rest of his time being taken up with house to house visitations to the planters. As his district extends to und includes Sandwich Bay, one lundred miles to the south, where there is a litrge settlement, the time devoted to each family is small. The Episcopal church has a mission school at Sundwich Buy, in charge of Mr. L. Dicks, who also travels from house to house, instructing the children.

Education. In spite of lack of cducational advantages, nearly everybody can rend and write, and all are very religious. As alcoholic liquors are not openly sold on the Labrador coast, cuses of intoxicution are exceedingly rare, and many of the younger people do not know the taste of alcohol. On the whole, these people compare favourably with those of more civilized regione, being frugal, moral, willing, good tempered, and naturally intelligent; their only fault, want of thrift and providence, is largely due to their mode of living, absence from any market of competitive labour, and the system of credit and debt under which they live.

Tribes of Indians.

The Indians of the Labrador Peninsula belong to tribes of the Algonkin fanily. The principal tribes of Labrador are the Montagnais, the eastern and western Nascaupees, and the constal Indians of Hudson Bay. The Montagnais inhabit the country extending south of a ' line drawn westward from Hanilton Inlet, to the headwaters of the St. Maurice River. The Nascaupees inhabit the interior country north of this line, or from the bottom of James Iay enstward to Hamilton Inlet. The northern limit of their territory is marked by the Koksoak River, from its mouth to the Stillwater Branch, and by this stream westward to its head on the neiglibourhood of Clearwater Lake, and thence westward to Richmond Gulf on Hudson Bay. This line divides the Indian territory from that of the Eskimo, and the boundary is well observed, 
the latter keeping far to the north of it, when hunting deer inland, and the Indiuns mrely crossing it from the southward.

The coastal Indians of Hudson Bay are confined to a narrow nıargin extending from the bottom of James Ba, to Little Whale River, along the enst const.

The various tribes are elosely related by intermarringe, and, nlthougl, Close relution using different dialeets, have many manners and customs in common. of different The northern Indians have apparently migrated to their present territory, from a south-west dirction, as their language contains many worls of the Santeaux or Ojibway tongue; wherens the southern Indians spenk purer Cree. The Nascnupees have traditions that their people originally dwelt far to the sonth, on the north side of a great river, with the sea to the eastward. They were driven northward by the Irofuois during the wars of the early French régime in Canada. Such was the torror inspired by the Iroquois, who followed then beyond the firar of the southern watershed to the shores of Hudson Bay, and eastward along the St. Lawrence to the Natashqunn River, that at present they use their name to frighten the children. The writer had two Iroquois as canoemen on the Big and Great Whale rivers, and could only with grent dilliculty, induce the native Indians to accompany him inland along with their traditional foes and conquerors. There are several places between Hudson Bay and the Lower St. Lawrence, where great massaeres of the natives were-perpetrated by the Iroquois.

The Montagnais are more or less of mixed blood, having intermarried Montagnais. with the old eourenrs des beis and the French and English traders. This admixture of white blood is seen in the better physique of the tribe, the men being more muscular and broader than the pure Indinu of the interior. As a rule, the men are of medium height, but a few are tall. The women are inclined to obesity as they advance in years, like their sisters of the northern tribes. The western Nascanpees are, Nascaunees. as a rule, the tallest men in Labraclor, many of them being six feet and over in lieight, straight and of light plysique. The eastern Nascaupess are usually not above five feet six inches tall, slightly built and not at all museular, being incapable of carrying half the loarls of the Montagnais. They are also the dirtiest and most degraded Indians of Labridor. The eoastal Indians hilve apparently a large Coastal admixture of white blood, as many of them have blue eyes and the men lndians. as a rule lawe strong beards. They bear in figure and face a certain resemblance to their northern neighbours the Eskimo, being heavily built and unlike the typical Indian. The admixture of white blood would account for this difference of physique, and it may also have 
been induced by their living along the sen coast. Their resemblance to tha Eskimo is not likely du to a blood relationship, as the Indians and Eskimo never take wives ane another, nor have sexual intercourse together.

Vory litt e is known definitely about the philology and ethnology of the Indiens, and the present account is only from desultory information picked up among them loy th's writer.

Langunge. This language, as before stated, is various dialects of Cree, or a mixture of Dree and Ojibway. The cialects are more numerous than those of the inur tribes given above. The Montagnais of Lake St. John speak a somewhat different dialect from that of Bersimis, and it again differs from the dialect's of Mingan or Northwest River. These differences of dialeci : : the same tribe are slightit, and are mostly in the slang and interjections. The same differences apply to the dialects of the Nascaupee, Mistassini and Nichicun, differing from that of Fort Chimo, and all from thet of Whale River and Rupert House. But these differences are all so small that the Montagnais canoemen conversed readily with the natives at Mistassini, Nichicun, Fort Chimo and Northwest River, and were only slightly puzzled on the coast of Hudson Bily, where the number of Ojibway words is greater. A Religion. large majority of the Indians of Jabrador are Christians, the Montagnais of the St. Lawrence and Hamilton Inlet being Roman Catholics, while the Indians of the western watershed have been convr ried by the missionaries of the Church of England. Only the easuer: Nascaupees are pagans, and most of them have a faint tinge of Chi:stianity, imparted on hurried visits by the Roman Catholic missionaries, between Hamilton Inlet and Ungava Bay. The christianized Indians are devoutly religious, attending strictly to the offices of the church during the long periods of absence from the eye of the missionary. While in the woods, they keep track of the weeks, ticking the days off on a rough calendar. They do not work on Sunday, and observe the fast days. Notwithstanding their careful observance of the offices, their religion is to a considerable extent leavened with old pagan superstitions, and a sneaking regard is still held for the windago and other Conjurors. evil spirits of their forefathers. It is almost laughable to see the respect with which the most religious of them treat the well-known conjurors or medicine men of the pagan Nascaupees; and they all secretly believe that these persons can, if they wish, work harm by the aid of evil spirits. All the Christian Indians can read and write, Education. those instructed by the English missionaries using a kind of syllabic shorthand, wisile those üuder the French missionaries make use of books printed in the ordinary way. 
Dishonesty and theft are unknown to the interior Indians; pro- Honesty. visions and outfit can be left anywhere inland with perfect safety for any length of time. Only in a case of absolute starvation will provi. sions be taken, and then only a sniall part, for which payment will be left by the person taking them. It is to be regretted that along the coasts, where the Indians are in close communication with the whites, their honesty suffers, and a good lookout must be kept, or property will be stolen.

As a rule, the Indians have not a strict regard for the truth, and Morals. speak it only when convenient. The missionaries have improved the moral and sexual relations of the Indians, but there is still room for improvement in the latter respect. Marriages are made early, the Marriage. men taking wives as soon as they can support them, and the women being given in marriage when they are fourteen or fifteen years old. Anong the Christian Indians monogany is practised, and the marriage ceremony is performed by the missionaries, or, in their absence, by the officers of the Hudson's Bay Company. Among the pagan Indians many of the men have two wives, and some three or four, according to the number they can support by their hunt. Continence is not usual. Widows are in great demand in marriage, and often a young 'oy is mated to a woman old enough to be his mother. As a widow inierits her dead husband's hunting grounds, a marriage with her provides the second husband with huniing grounds as well as a wife, and in consequence widows are taken by you $\mathrm{g}$ men without lands. The respect shown by children to parents is great, and the will of the aged father Childreu. is law, even with middle-aged sons, who will not enter into any serious undertaking without first consulting the head of the family. Children are never beaten, 'su soon learn to obey without punishment. As a rule, the number of children borne by the women is small, rarely exceeding five. The women become wrinkled and old before they are forty years of age; after which they often live for many years. The men show the effects of age much less than the women, and it is exceedingly difficult to tell their exact age between 50 and 70 years, as the hair rarely turn. grey. The greatest mortality is due $w$ pulmonary disenses, which are induced by exposure to cold and wet, with no Dianase. covering on the feet but deerskin moccasins, which sonk like blottingpaper. "Lame back" incupacitates a number of the men, and is probably due to disease of the kidneys. Complaints of the stomach are also the cause of many deaths, owing to the weakening of that organ by alternate periods of starvation and gormandizing. Scrofulous sores and ulcers are not uncommon, and appear to be inherited. 
lininl. The dead throughout Labridor are buried in the ground, and, only when death takes place during the winter, is the body pluced in a treo. until the frost is out of the ground. The elothing, gun and other artieles belonging to the deceased are often buried with him, or placed on the gruve, when the burial takes place in the woods, and no Indian would touc', anything so left, or cump near one of these lonely graves. The dead are mourned for aceording to the position they oecupied, unt the griot displayed is deep and sincere. A curious custom was noted in the interior, on the arrival of the various families at the posts in the spring - instend of joyous greetings the women elasp one nnother and indulge in a period of silent weeping, ufter which they eheer up and exclutuge gossip.

Moute of living.

Aunual visit ti) the const.
The annunl routine of an Inclian life is made up of two periods, the short period, from one to three months, spent cluring the summer at the const, and this long peried passell inland. Those who tracle at the inland posts, are engaged throughout the summer transporting to Hudson Bay the fur hunt of the past winter and bringing back the supplies to form the next season's outfit. 'The amount of supplies is so great and the number of men at these posts is so small, that every one enpuble of working is enlisted, ineluding half-grown boys and old men. As most of the women and children aceompany the brignules of lnrge canees, in their suall canoes, the journey practically unounts to $n$ co-operntive scheme of bringing in supplies, and differs only in this respert from the annual visit to the coast of the independent fumilies. The ouly Indians who do not come in eontuet with the white traders during the summer, are some eighteen fnmilies who reside on the shores of a large lake about two hundred miles above the mouth of the George River. These Indians never visit the eoust during the summer, and their only eommunication with the white traclers is during the enrly spring, when the younger men tramp to Davis Inlet on the Atlantic coast, and there trade their furs for tra, tobacco and anmunition. They do not buy clothing or provisions, and haul their purchases home on long nurrow toboggans over the erusted snow. This little tribe of Indinns carries on a small trade in the above mentioned artieles with the other neighbouring Indinns of the interior. As they reside in a distriet plentifully supplied with caribou, they depend upon tirese animals both for food and elothing, and are thus practically independent of the traders.

The majority of the Indians who go to the coast, eongregate at convenient centres in bands of six or more fanilies, and in company descend the rivers in their smal! bark cunoes. The time of the spring gathering is shortly after the ice leaves the rivers, when the fur of the. 
otter becomes "common." Finch fumily carries with it the packs of furs obtained during the winter, together with most of their movable property. Those living furthest inlund are often more than two weeks in rleseending to the post, owing to the long and diflicult "roads" they have to fullow. On arrival it the eoust, the fur-pncks are handed over to the trader with whom the Indinn deals, and $n$ valuation being set upon them, the Indinn is allowed eredit for the value computel in "skins" or " benvers," which are the units of viluo in the trucle-the Fur trale. price of the diflerent furs being reckoned in compurison with a menliun sized henver skin, and the traders' supplies are valued in the same munner. On the St. Lawrence const this systcu of burter is fulling into disuse, and ensh is taking the plnee of the old benver as a medium of exehunge. The summer srason at the posts is pnssed in visiting friencts und in a round of gaiety. Vory few of the Indinns have been Summer life. induced to cultivate !nnd on their own nceount, althongh they sometimes work in the gardens of the tralers and missimuries. The only work that they willingly nndertake is in ennoes, either nttenriing fishing prurties or trnusporting provisions inlund. During the summer senson a majority live in smull cotton tents, but some of the most successful hunters own small $\log$ houses, in which they pass the suinmer. During the month of Angust, preparations are mnde for the journey to winter quarters, nnd by tho end of that montl most of the Indinus lenve the vurious posts.

Owing to the extermination of the earibou in many parts of the country and to an insuticiency of other gane, the greater number of the Indians ure now obliged to purchase a considernble quantity of flour, and earry it inland to their hunting grounds.

So much pr visions, along with other outfit, are now taken by the Trananort of southern Inclipns that they have to make two or three trips with their supplies. eanoes at starting, and often they are more than two months in reach. ing their winter qunrters. In former years, the Hudson's Bay Company and other traders annunlly advaneed the Indians suffieient provisions and outfit to earry on their winter's hunt, and recouped themselves in the following spring At present, to a great extent, this Change in system of advnnees has been abandoned, and the Indian only gets sueh system of outfit and provisions as he can puy for in eash or fur. The change is due largely to the losses entniled by elose competition, and to the dishon. est practices of many of the Indians, who instend of delivering their fur to the persons who arlvaneed to them, take it to rival traders and exchange it for eash or other articles-leaving their debts unpaid. The change is consequently justifiable where there is competition in the Its relation to fur trade, but bears heavily on the Indian, who is naturally improvident the Indian. 
and spends the proceed of his sunual hunt as soon as ho gets it, withsut thought or cure. In eonsequence, when the hunt is n fuilure, which is often the case through no fuult of the hunter, the poor Inclian lans little or nothing to buy his ou fit with, und departs to the woods im. properly supplied. To this $c$ use is due much of the hardship, starvition and death reported anong the Indinus of the Iabrulor Peninsula during the past fow ) 3ur. With the exception of the eastern Nascaupees, ull the Indians now dress in clothing procured from the trading shops, und many of the southern Indinns, having acquired a taste for luxuries of civilization unknown to their fathers, must muke large hunts in order to gr:tify these tastes.

Huntiug uromincis.

Fixtermina. tion of fur beariug แuimunls.

Winch fumily is supposed to own a portion of territory with tho exclusive hunting rights to it. The territury is generally divided into three purts, ench part being hunted over in successive yenrs, and in this manner the fur-benting nnimals are allowed to recuperate. In the southern country extensive fires, too close hunting, and other causes ure rapirly exterminuting the animuls, and the fumilipy o vning these grounds, in order to obtnin a living, are obliged to encrouch upon their northern neighbours. As the intruclers care little or nothing about keeping up the stock on these lands, the result is most disastrous, and in a fow years, if strict luws are not enucted, the fur-bearing auimals of the province of Quebec will be pritically exteruinuted, and the Indians, thus left without their only means of subsistence, will be reduced to beggary, or will die off from fumine.

Winter tent. As soon as the liunting grounds are reached and the cold wenther begins, the cotton tent is exchnnged for the wigwam or "metswap," which is constructed by removing the snow from a circle ten or twelve feet in dinmeter, about the circunference of which poles six or eight inches apart are planted sloping inwards so as to form a skeleton cone. This cone is covered with cotton cloths, sheets of birch bark, or dressed deer skin, often in part by all three, and a space is left at the top about two feet in diameter for the escape of the smoke. The removal of $n$ pole leaves the space for a door, which is generally closed with an old flour-sack split open, and bound to sticks at the ends to keep it spread out. The bottom of the tent is banked up with snow on the outside, while $n$ thick bed of green houghs is laid over the floor. The fire is built on a few stones in the centre, raised slightly above the ground. Many of the southern Indians have small stoves made out of sheet-iron instend of open fires, and thus avoid the con. stant smoke which fills the interior, especially when the door is frequently opened. 
Before the lakes and streams freeze up, hunting is largely earried on dutumus hun witl, the gun, the Indins shooting from their canoes heaver, otter, mink and inuskrnts, and in the burnt nren, where blueberries are plentiful, benrs. The northern Indians at this time are enguged in their principal caribou hunt, killing grent numbers by spenring them in the rivers, as they pass on their annual migrations. After the rivers are frozen, most of the fur hunt is mnde with traps ; these are either steel trups or dend.fulls of wood. The principul animuls taken during Wiuter hunt. the enrly winter are marten, fox and lynx. During the intense cold of December, Janunry and Februnry, the wild animuls move nbout very little and hunting is unprofitnlile. During this period the Indians (li) not hunt unless eompelied to do so by hunger. In the month of March, the martens are once more truvelling, and continue to constitute suring hunt. the principal hunt until the small strenms begin to brenk up, when attention is given to the leaver nnd otter and, later on, to the bear. In this mnner the winter routine is earricd ont, with the intervals mostly filled in looking for food. Ptarmigan and Canada grouse are killed cluring the winter, nlong with rabbits, which are periodically plentiful, while lish, ducks und geese aid in stoeking the lurder in the spring and fall.

When the St. Lawrence was first discovered, the Fskimo inhabited Fiskimo along the north shore of the gulf as far west as Mingan. They maintnined the St. Law: their position here until 1600 , when the Indians, hnving procured firearms from the French, waged unequnl war on their old enemies and drove them enstward to the Strnit of Belle Isle, where the Eskimo maintained a fortificd camp on an island near the western end of the strait until 1630. Since then, a gradual retreat has been inade northward, and their present southern limit is Hamilton Inlet, which appears to have long bcen the head quarters of the southern Eskimo, and is named Eskimo Bry on all the older maps. From here these people are scattered along the northem const to Hudson Strait. Several large settlements are found at the Moravian Mission stations of Hopedale, Zoar, Nain, Moruviau Okak and Ramal on the Atlantic coast. There are very few families ${ }_{\text {stations. }}^{\text {Mlisiou }}$ between Nachvak and George River in Ungava Bay, the eonst being high, desolate and unfit to sustain a large population. The Eskimo are more numerous along the west const of Ungava Bay and Hudson Strait, and are found along the east coast of Hudson Bny, and among the outer islands of that coast, as far south as Great Whale River. Of late years, some three or four families have hunted on the islands in James Bay.

Turner* divides the Eskimo inhabiting the coasts of the Labrador Tribew of Peninsula into three or four sub-divisions, on account of sub-tribal dis- Eskimo.

* Anuual Report U. S. Bureau of Fthnology, 1889-90.--Ethnology of the Ungava District, Hudson Bay Territory, Lucien M. Tu'ner. $4 \frac{1}{2}$ 
tinctions maintained among themselves. The names given to these tribes, by Turner, are those used by the Eskimo of Ungava Bay. The first subdivision includes all those divelling along the Atlantic const and along the south shore of Hudson Stritit to the mouth of the Leaf River, a few miles noith ward of the mouth of the koksonk River. These people call themselves Suhinimyut, "those who dwell at or in the sun," or the dwellers in the east. The second sub-division embraces the Eskimo dwelling along the south shore of Hudson Struit, between Lenf River and Cape Wolstenholme, at the entrance to Hudson Bay. These people are called the Tahagmyut, "dwellers in the shade," or the western people. By the Hudson's Bay Company they are krown as "Nortlerners." The third sub-division includes those living along the east const of Hudson Bay, und they are clesignated the Itivinyut, or "the dwellers on the other side." A fourth division may be made of the Eskimo of the outer islands of Hudson Bay, who, accorting to the traders and onissionaries, differ from their neigh'ours along the coast, both in language und customs. They are known as the Kigiktugmyut, or "Island people." Along the Atlantic coist, as far north as Hopedale, few or none of the Eskimo are pure bloorled. To the north. ward the Moravian missionaries keep the natives from contact with the whites, and in consequence there are very few of mixed blood. In Ungava Bay and on Hudson Bay there are, around the Hudson's Bay posts, many half-breeds, the result of marriage between the employees and Eskimo women.

Inprovement The natives along the Atlantic const, from Hopedale to Nachrak, by mis:ionaries. bave long been under the direct influence of the Moravian missionaries, and, in consequence, have abandoned unany of their ancient customs. Polygamy is no longer tolerated among them; in many cases they conform with a fair standard of civilization, and are quite religious, although very superstitious.

On the coast of Hudson Bay, mainly through the endeavous of the Rev, Mr. Peck, of the Church Mission Society, most of the liskimo have been converted to Christianity. On this coast the missionaries do not reside constantly among the natives, and in consequence these people are very liable to relapse, during their absence into some of their former pagan habits. The Eskimo of Hudson Strait hnve not yet been brought under the influences of Christianity, and afford a better chance for the study of their native customs and traits.

Physique. It is customary to think of the Eskimo as considerably below the stature of the average European. This is not the case with those inhabiting the coasts of Labrador. The males, as a rule, are quite as tall as the avernge white man, but owing to their broad, heavy build, 
they appear sherter than ti:sy really are; and this appearance is enhanced by their wide garments of hairy deer or seal skins. Where seen by the writer on Hudson Bay, and at Fort Chimo, George River, Nachvak, Davis Inlat and Hamilton Inlet, several of the men at each place were six feet and upwards in height, the average height being about five feet six inches. The women, as a rule, are short and stout, and look in their native dress of deer-skin coat, trousers and long scal beots, inuch shorter than they actually are.

The temperamen of the Eskimo differs much from that of the Tempera. Inclian, the former being jovial, good-natured and very industrious. ment. They are good workers with tools, and on the Hudson Bay coast the blacksmiths confess that the natives, without the use of a forge, can work and temper iron better than they can. These people, livins as they do on the cosst, depend largely upon marine animals for focd Food. and clothing. Their principal food is seal meat, together with pu:poise, whale meat and fish. They also kill many caribou, to the north of the Koksoak River. For this purpese, they travel inland from the const, but the pursuit of this animal is shiefly for its skin, used in clothing. The hunters quickly tire of the Sesh, it being not fat enough to suit their taste. During the winter, chey hunt fur, to purchase what supplies they may need from the traders. The principal furs taken by them are red, cross, black, white and blue foxes, white bears, wolve; and wolverines, besides deer and seals. The Liskime have not a; many civilized wants as the Indians, the prin-Trade. cipal articles of tride taken in exchange for their furs being ammunition, tobacce, knives and iren, tea, sugar and needles. They do not buy much flour or biscuit, and very little European clothing.

With the exception of the Atlantic coast Eskimo, who live at rut Habitations. the mission stations in small log houses, the summer camp is made much like an Indian wigwam, save that it has a ridge-pole, and is covered with seal-skins. During the winter, small circular snow houses are used. For travel during the summer, two kinds of boats are used, the kaiak or men's beat is long and narrow, and formed of a wooden frume covered with seal-skins, leaving only a small circular opening large enough to admit the body of a man. The bow is long and pointed and projects above the water forward, the stern is fuller, and much lower and rounder. This craft is for one man, who pro- Boats. pels it with a doublebbladed paddle, and it is used for hunting. In these small boats the islanders of Hudsen Bay frequently cross some fifty miles of open water to the mainland.

The umiak or women's boat is much larger, and like the former is made from seal-skins stretched on a wooden frame. In stape and size 
it resembles a deep, flat-bottomed punt, and is capable of carrying the heavy seal-skin tent and all the other belongings of a family, when moving from one place to another. In winter, dogs and sleds are used to travel with, the Eskimo not being nearly as good a walker as

Sleds.

Cooking utensils.

Diseast.

Marriage. the Indian. The sleds are made of two runners of wood, from nine to eighteen feet long, held in position, from eighteen to twenty-four inches apart, by numerous cross pieces. The sled is shod during the cold winter months with walrus ivory or whalebone attached to the runners with wooden pegs, or else the bottom of the runner is coated with vegetable mould, which is frozen on and then shaped with a knife or plane so as to resemble the head of a large T rail, botl in shape and size. This is coated with a thin skin of ice and answers admirably during the cold unbroken winter. In the spring time, runners of hoop-iron are preferred. During the winter, conking is carried on in the snow houses over soapstone lamps in the form of a shallow triangular dish, about fifteen inches long and eight inches wide. These dishes are nearly filied with seal oil, and the wisk is formed of dry moss placed round the sicles. Formerly soapsione kettles were used for cooking, but these are almost entirely superseded by tin or crpper kettlec purchased from the Hudson's Bay Company.

The habits of the I ncivilizer? Eskino are far from cleanly, and they appear to have a denided objection to the use of water except for drinking purposes. In cor sequence, the principal diseases from which they suftior arise from their filthy habits and the close vitiated atmosphere in their tightly closed houses, laden with the odours of decomposing animal food and other filth. Orer half the Eskimo die rif pulmonary troubles due to these causes and to exposure. Many suffer and die from scurvy, caused by devitalized blood and their excessively fatty food while remaining sedentary during the winter. As a rule, munogamy is practised, although many of the better hunters among the unchristianized natives have two und some three or four wives. The women are married early, generally at about fourteen or fifteen years and often before that age, and these early marriages result in few and weakly children. 'The marriage ceremony is very simple. The consent of the parents or other relatives of the girl is obtained by presents or fuvour, and, if the girl is favourable to the union, she goes with her husband. When the girl refuses, she is soon coerced by her relatives. The marriage tie is easily broken, and it is seldom that a man lives with a woman for a ntunber of years. Jenlousy, resulting from a laxity of morals or incompatibiity of vemper, dissolves the marriage without ceremony, the woman returning to her relations 
until taken by another man. The family is usually of two or three Children. children, although there are sometimes eight or ten, but many die in childhood. Like the Indians, the Eskimo never inflict corporal punish. ment on their children, who without it early learn, however, to obey and respect their elders.

The dead are placed in a sitting position, with the knees drawn tightly up, and the whole body covered with seal-skin or deer-skin. The body is placed in this manner on the bare rock, and is covered with stones to prevent the birds and animals getting at it.

Like the Inclinns, they believe in a future state, where the spiritual Beliefw. conditions closely resemble those of the material world. As every object is endowed with a spirit, clothing, spears, gun, kaiak and other articles, are deposited near the grave, so that the departed may use the spirits of these articles, in his new existence separatcd from the body. The spirits of material objects are supposed to be released as soon as they decay and if they are found removed, it is said, that the spirit of the dead has taken them for nse in the spiritual world. All objects animate or inanimate, have both a material and a spiritual existence; and there are cther spirits, mostly of a malignant character, which can be appeased by gifts.

It is easy to understand that, holding such beliefs, they highly Conjurors. esteem, fear and respect the conjurers, whom they suppose to have power over the various spirits, including those that cause disease and death. The conjurers also clain to influence the movements of the Jeer and other animals, and are supposed to control the weather. Unlike the Indian conjurer, who performs his incantations concealed in a small tent, his Eskimo confrère invokes and exorcises the malignant spirits openly, $n \mathbf{r}$ with only his head covered up. Some of the Eskimo while away the time during winter, by making rude carvings Art. ont of walrus tusk or bear teeth. The sarvings represent various birds and animals, or models of their boats, sleds, or implements. Some of the carvings show considerable skill and artistic taste, especially those made under the direction of the Moravian missionaries.

The Liskimo are very fond of singing, instrumental music and danc- Yusic. ing, and readily learn to play the violin. At Hopedale and Nain the natives have orchestral music to accompany part singing in the church services, and inany of the Eskimo of the Atlantic coast play second parts on the violin, showing that they have a fi: idea of harmony.

\section{Fisheries.}

In the appendices at, the end of the present report will be found lists and short notes on the mammals, birds and fishes of the interior of the 
Labrador Peninsula, and it remains only to remark here on the vaiue of the inland tisheries. The numerous large lakes of the several water. sheds, and most of the rivers, especially those flowing north and east,

Food fishes of are stocked with an inexhaustible supply of food fishes of large size inlınd lakew. and superior quality, including among other species the lake and brook trout, land-locked and sea-run salmon, whitetish, pike, pickerel, suckers and ling or freshwater cod. Along the southern, eastern and northern coasts. the cod is taken in large quantities as far as Ungava Bay, which is the present limit where trial has been made for taking this fish. Salmon are found plentifully along the consts as far as the west side of Ungava Bay, which appears to be the western limit of the Atlantic salmon. Very little is known officially or otherwise concerning the

Hudson Bay. fisheries of that great inland sea, Hudson Bay, and a great amount of wealth may be lying ciormant in its waters from lack of knowledge concerning its fisheries. As regards the inland tisheries, owing to the distance from available routes to a market, they will probably never be used to their full extent, and even the best situnted lakes will not be fished for many years to come, or until railways are built tlirough the interior. Three large lakes of the interior are known to contain considerable numbers of harbour seals (Phore vitulina), which are completely land-locked, and never visit the ocean.

\section{Detailed Description of Routes Explored.}

\section{Chamonchonan River.}

Chamouchounu River.
The Chamouchounn River enters Lake St. John at its north east corner. It is about three-quarters of a mile wide at its mouth, and is very shallow when the water of the lake is at its lowest stage, there being a difference of twenty-seven feet between the high and low water level of Lake St. Jolm,* owing to its contracted discharges being unable to carry off the great volume of water brought down in the spring by the numerous large rivers enptying into it. The river; in its lower part, is obstructed by three large and several small islands, that extend upwards to St. Felicien, some eight miles from its mouth. Its current for this distance is sluggish, the river flowing between low banks of eliny and alluvium. During high water the lake backs up to this point, flooding much of the low lands on either side.

At St. Félicien, there is a small rapid full of large boulders, and for five miles above, the current continues swift, to the first heavy rapid,

*Levels of Q. \& I. St. J. Ry.-High water, $353 \mathrm{ft}$; low water, $326 \mathrm{ft}$. alowe nealevel tu Quebec. 
where a portage is necessary. This portage is 150 yards long, and passes over the bare rocks. Twelve hundred yards above, is the Salmon Portage, where the river falls over two cascades, the upper being a direct fall of fifteen feet.

One mile above the portage, the Salmon River enters from the west. Salınon River. This stream is about fifty miles long, and takes its rise in a number of small lakes, near the sources of the Croche and Windigo bre:-ches of the St. Maurice River.

The third portage is about seven miles above the second. Between them the river is abont 500 yards wide and flows with a swift current, the banks, which have been gradually rising from St. Félicien, are now in places above 100 feet high, and are.composed of clay overlain by stratified sund.

It is three miles and a half from the third portage to the Bear Beari'ortages. Portage, where there is a fall of fifty feet. This portage is on the east side, and is a mile and a quarter long. From its upper end to the Little Bear Portage, the distance is a mile and a half. Here, a rocky point jutting out from the east side. causes the river to make a sharp turn, with a fall of about twenty-five fect. The portage is 300 yards long and crosses the point.

Within the next two miles, there are two other portages on the east side, past heavy rapids, the whole bringing the river up nearly to $n$ level with the surrounding country.

Beyond the last portages there ure small rapids at intervals for a mile, then the river widens out to about a third of a mile, and flows with a strong, even current, in a shallow sandy channel, for seven miles, to the thirty-fourth mile from its mouth. Five large islands lie in this portion of the river. They are all low und sandy and are well. wooded with swamp ash, elm, balsum poplar and willow. Along the lower parts of this course the banks are low, and the surrounding country flat, with a soil of sandy loam. As the other end is approached, Sandy soil the banks rise gradually, until at the shurp bend to the westward, one above the the banks rise gradually, until at the shurp bend to the westward, one lbear Portage. unile from the end, those on the east side rise abruptly over one hundred feet above the water, and are composed wholly of stratified sand. At this bend a portage route passes up the steep bank to the that sandy plain above, which it follows northward through several small lakes on the head-waters of Piconabi River. From there the route passes into Lake Jim, a long narrow body of water that extends northward in what appears to be an old river-valley, until it joins the Washimeska River, which, above the junction, flows in a continuation of this valley, while below it turns eastward, and with numerous rapids and falls empties into the Mistassini River. 
After the westward course of one mile, befsere mentioned, the Chamouchouan River again turns north, and a series of $\operatorname{lon}_{b} ;$ heavy rapids begin, the lowest of which is called the Pimonka (last pine) Rapid.

The land on both sides of the river, as for as Pimonka, lus been laid ont into townships, und sub-divided by the Quebec goverument. The townships of Parent and Normandin are on the east side, while those of Ashouapmouchouan, Demeules and Dufferin are on the west side.

Ciool liud along the lower river.

Settlements. The soil along the lower parts of the river is very rich and strong, being formed of a clay sub-soil, with sandy loam on top. Above the Salmon River, the deposits of sand are thicker and the soil is lighter, but still sufficiently good to produce excellent crops of wheat and other cereals.

The Archean higlılands come within a mile of Lake St. Jolnn, on its west side. These continue northwird, but do not cross the river until the foot of Pimonka Rapid is reachel, thus leaving a wide margin of that land on the west side. On the enst side there is a flat clay and sand plain between the Chamouchouan and Mistassini rivers. This plnin rises in a succession of terraces from Lake St. John northward.

Settlements extend up the west side of the river about five miles beyond Salmon River. On the east side, they approach close to the Bear Portage, while the road to Normandin, a large settlenent along the Picounbi River, passes close to the Little Bear Portige. Advantage is taken of this road to transport canoes and outfit past the rapids and portages below.

From the above, it will be seen that, although considerable settlements exist along the river, there is much good land still unoccupied, especially between the Little Bear Portage and Pimonka Rapid.

Above this rapid, the character of the country and river chnnge completely: the former, instead of spreading out into a flat, sandy plain, is high and rough, with rocky hills that rise from 150 to 300 feet above the river. These are covered with sand and boulderclay, and are not nearly so fit for purposes of agriculture. The river becomes contracted and very rapid, rising 341 feet in twenty-two miles, including the Chaudiere Fall and rapids, where the rise is 120 feet in less than a mile. The Pimonka Rapid is three-quarters of a mile long, and is followed in the next nile by two short ones. Extending from the thirty-ninth to the fortieth mile, is the Deep-bottom Rapid, which cannot be ascended with canoes cluring high water, owing to the depth inshore being greater than the length of the poles, and also to the steep rocky banks, which render tracking impossible. With the exception of one short rapid, there is quiet water som the head of that rapid to the forty-fourth mile. 
At the forty-second mile, the Great Mouchipon River comes in from the west. It is a small stream, flowing in a valley about a mile wide, and draining a number of small lakes to the north-west. A portage route, for light canoes in the spring, passes up this river, and comes out above the Chaudière Fall, thus avoiding the heavy rapid between. From the forty-fourth mile to the Chaudière Fall, twelve miles above, Chundiere the river is a continuous succession of rapids connected by short Fall. stretches of swift current, rendering it necessary to mako the whole ascent with poles. At the White-spruce Rapid, near the forty-ninth mile, there is a short portage on the west side past a heavy pitch.

The country becomes more rugged as the river is ascended. The Timber. hills rise abruptly from 200 to 400 feet above the water, and, as they vere burnt over some yeurs ago, their rocky sides are no'v only partly wooded with small second-growth aspen, white birch, Bunksian pine and spruce, while the standing blackened trunks of the older forest give the whole region un uninviting, barren appearance.

The portage past the Chaudière Fall is nearly a mile long. From its lower end it rises sharply 200 feet to the summit of a sandy hill, and then runs along its edge, to within a short distance of its upper end, where it passes along the rocks near the river. There arc here three distinct falls connecied by heavy rapids, the lower fall having a sheer descent of sixty feet.

Within half a mile of the upper end of the portage, is another, about 400 yards long, called the Little Chaudière Portage. It passes a deep heavy rapid, impassable with canoes.

A short distance from the head of this portage, the river leaves the narrow rocky gorge in which it has been confined, and its valley broadens, leaving a wide margin of low land on either side. The course of the river can be seen up the valley for over ten miles. The Good land river has a moderate current in. a wide valley, bounded by low, alove the rounded, rocky hills, covered with small second-growth timber. Much Finll. of the land in this valley appears fit for agriculture.

About one mile above the Litlle Chaudière Portage, the Chegobich Chegobich River comes in from the westward. This river is much used as a route River. by the Indians who travel to or beyond Lake Ashouapmouchounn. By it the distance to that lake is greatly shortened, as this route is the hypothenuse of a right-angled triangle, of which the main river forms the other two sides.

The Chegobich River varies from fifty to one hundred yards in width near its mouth, and is quite shallow. As far as the first portage, 
a mile and a half up, the banks are low, and are composed of coarse boulder-lay. The first portage is one hundred and twenty yurds long, and pisses a heavy rapid; it is followed, a quarter of a mile above, by a second portuge, over one mile long, past another henvy rapid, ending in a chute of forty feet. Then follows a mile and n quarter of sw:ft water, with two short portages, to the Penché Portage, 700 yards iong, with the Savanne Portage, of 200 yards, $n$ half mile above. leyond this th te pre stretches of sluggish water, broken by small rapids for four miles, when a portage of 360 yards passes a chute of twonty-five feet.

From the first portage to beyond Savanne Portage, the country surrounding the river is rolling und somewhat rocky, with snall second. growth forest covering it. Beyond the Savanne Portage, the banks are low and sandy, with swampy land extending to the low hills that bound the valley on either side, from half a mile to a mile awny from the river. Patches of old forest remain on the swampy land, but by far the greater parc is small second-growth trees.

Above the chute, the river for nine miles winds through a wide, swmpy valley, its sluggish current being broken only in a few plices by short rapids. In this distance a number of snall tributaries enter, chiefly from the south-west, where they take their rise in numcrous lakes on the enstern slope of the Partridge Mountnins. These form a ridge of rounded hills, that appears to run nearly north-and-south and to cross the river near Chegobich Lake.

The river, having now become very small, is inclosed in a narrow volley betwen rocky hills that, rise from one hund a to three bundred feet above it. and in the next cwo miles to the lake it is nuch broken by rapids, filled with large boulder's, entailing several short portages.

Cheoobich

Lake.

Chegobich Lake runs northward for nine miles from its discharge: it then turns sharply to the eastward, and extends in that dirertion some fifteen or twenty miles. The genera! wilth of the soutliern arm is abnut one mile. It is said to be very deup and the water is elcar and brownish. Only three small rocky islands are found in the southern arm. The lake is surrounded by low rounded hills, highest on the east sid's, where they culninate in Chegobich Mountain, a bold rounded hill rising $4 \% 0$ feet above the water near the outlet, and forminy a conspicuous landmark. The other hills on this side never exceed an elevation of 350 feet, while on the west side they are less than $200 \mathrm{f} . \mathrm{t}$. There was more unburnt timber about this lake than had been seen anywhere along the route from Lake St. Joln ; but it is nov large, and is ehiefly blinck spruce. From the angle between the 
two arms of the lake, $n$ portage a mile and a half long, passes wegtward over a flat, dry, sandy plain, und ends at a small sluggish stream. This strenm lus a very tortuous course through a wide swamp. After passing two small lakes, it finally flows into the south-east end of Lake Ashoun pmouchonan, two miles and a half from the portage in a strmight line, but over seven miles by the crooked course of the river. A few low, rounderl hills of gneiss rise out of the swamp, but, apart from these, there is very little solid land, where small bla :. spruce, lajeh and Banksian pine are found growing.

Lake Ashounpmouchouan is ahout six miles long with an average Lake Ashonhreadth of one mile. Its shore-line is broker. by a number of rocky aptuoucliouan. points and shallow bays, while the surrounding country, ts a rule, is low and flat, with a few ridges, never more than a hundred feet above the level of the lake, which, according to Richardson, is $118+$ feet above the sea. 'The water is not nearly so cleep or clear' as that of Chegobich Lake. The surronnding country seems to be highly fertile, and in the clearings about the old Hudson's Bny post tinothy grass grows in abundance, while sinall fruits appear to ripen early.

The Chamouchouan River, ahove here called the Nikautau River, Nikaubau flows in at the north-west angle of the lnke, and ubout a mile beyond River. leaves it again at the north-east corner. The northern part of tho lake is silted up with material brought down and deposited by the river, and is a favourite place for nets, great quantities of fine whitefish being caught there.

Above the lake, the Nikaubau River for several uniles, to the Pole Rapid, Hows with a sluggish current through a low conntry broken by a few rocky hills. Above the rapid, the land becomes higher and the soil, composed of boulder-clay, rises from twenty to eighty feet above the river, and is proken by an occasional rocky ridge sometimes 200 or 300 feet high. Little Nikauban Lake is alout twelve miles above Pole Rapid portage, and botween are a number of short heavy rapids, with a short portage past one of them. This lake is one mile across, and is connected by a couple of lake-expansions of the river with the larger lake three miles above. Lake Nikaubau is four miles long, and from a half to one and a half miles broad. It is surrounded by low and apparently swanpy country covered with a medium growth of spruce, larch, balsam fir, Banksian pine, aspen, balsam poplar, and white birch, with a few small cedars. It may here be noted that the ravages of the imported larch saw-fly (Nematus Erichsonii, Hurtig.) extend to the heiglit-of-land; the greater part of the larch trees Timber. have been attacked, and large numbers are already dead. It is learned from the Indians that these trees first showed signs of death 
north of Lake St. John, some three or four years ago. The trees north of Inke Mistassini still remain unnttncked, but it appears to be only " matter of time before all the lareh of Labraclor will be destroyed, as the pest is spreading rupidly northwnrd.

T'he Fonm-fall liver is the hurgest strean entering Lake Nikaubru; it flows from the south-west, and enters the lake nenr its outlet at the south encl. There is a route by this river to the liend-waters of the St. Maurice liver, which was surveyed by Richardson.

Countryalout hivight-of. lauil.

A small stream, flowing into the north end of the lake, leads by $n$ chain of six little lakes to the watersherl between the St. Lawrence und Jiulson liay. From Lake Nikaulnu it is twenty-four miles to the hearl of the strem and the surrounding country is llat, low and swumpy. One hill about 500 fert alsove the general level, lies close to the watershed and forms a eonspienous landimark.

Short stiff rapids are met with along the strean between the lakes. At the fourth or Brunch Lake, the river divides, the larger brunch flowing in from the north-enst, where it is said to druin a number of sinall lakes immediately south of lanke Wahwanichi. Owing to numerons lmpits and othep olstprictions it is unusel as a canoe route.

\section{Il-ight-of-Land to Lak" Mistussimi.}

The general course of the route from lake St, John to the height-ofland is nbout north-west, while the distance is nenrly one hundred and sixty miles. From the watersherl to Jake Mistissini the general direction is nearly $\mathrm{N}, 30^{\circ} \mathrm{E}$, or almost nt right-angles to the former conrse, the distance being about one lundred and ten miles. On crossing the height-of-land the route passes through three large lakes before reaching Mistassini. These lakes are named Ohatoguman, Chilouginoo und Wahwanichi, and they are connected with one another by portinge-rou es pissing through small lakes and the streams flowing from them.

Flevation at

The height-of-land, accorling to Richartson, is here 1360 feet above watershiel. sea-level. It is crossed by a portage of half $n$ mile, ending $n t$ a small strenu that flows into Lake Obatogaman, five miles distant. The fall to the lake is one hundred and fifty feet. The surrounding country is uneven and sandy, and supports only a sinall growth of black spruce and bireh.

Lake (Mhato- Lake Obatogaman is very irregular in outline, being broken up into agman. a number of deep baj's by long narrow points; its surfaee is also crovded with innumerable small roeky islands to such a degree that 
navigation without a guidle is almost impossible. The lake is estimuted to be nbout twelve miles long from north-east to south-west, and nbout ten miles broad. Its sliore-line inust eonsidernbly exceed one hundred miles in length, owing to the grent irregularity in its shape. The water is not very clenr, and as a rule nppenrs to be shallow. The out. let is in the south-wostern part of the lake, and forms $n$ branch of tho Nottoway River, which empties into Rupert Bny, the south-western extension of Junes Bay. Whitelish, pike, piekerel and suekers ure Fisli. caught in abundanee here, and sturgeon are nlso suid to ascend to the lake, and are taken at certain seasons in large numbers nenr the outlet.

The surrounding country, except toward the south, is generally flat Chatacter of and low, with ridges of low granite hills rising above the general eountry. swampy lands. The soil is thin and sundy azd the timber small nlong the shore and on the islands. It consists ehiefly of black spruee, along with balsain lir, white bireh, Banksian pine and larch. The ennoe route crosses the lake in a north-west direction for ten wiles, between ialands and past long points, to a narrow bny, which is followed northeast four miles to the first portage on the route to Lake Chibougamoo.

The portage-ioute is nine miles long, und first passes up a small strean falling into the head of v!le bny. Along this stream three portages are made past rapids, and then $n$ portage leads from the small swampy lake it its head, to snother small lake which discharges into Lake Clibougamoo. Following this sluggish stream four miles, through a swanipy country with low hills of rock rising at intervals, the south-west hay is renched. Along the portage-route most of the Timinr. timber has been lurnt ofl, leaving only elumps of black spruce and lareh growing on the lower swampy ground. The level of Lake Chibougamoo is forty feet above thut of Obntogaman. Its greatest Lake Chibou. length is nbout twenty-five miles, from N. $30^{\circ}$ E. to $\mathrm{S} .30^{\circ} \mathrm{W}$, nnd it gamoo. is over six miles wide in the brondest part. The southern end is divided into two bays by a narrow point, three miles and a half long. A. high rocky ridge projects twelve miles from the northern end, dividing that portion of the lake also into two bays, of which the enstern is the larger, being about twelve miles deep and four miles broac. The western bay is seven miles long, and is very irregular in width, being a suecession of small lakes connected by narrows. The lake has on its western side two outlets, about three miles apart. The northern one is near the mouth of the north-eastern bay. They are both only about 200 yards long, and the water falls twenty-five feet into another lake lying parallel to Chibougamoo, and separated from 
it only by " narrow rocky ridge. This smaller lake is twelve oniles long, and from one to two miles wide. The lake is well stocked with large lake trout and whitefish, and its water is very clear and deep. lirun it flows unother brunch of the Nottowny River, which unites with one from Ohntoganun seme consideruble distunce to the southwest.

Cluaractep of (a)inter ulumt Iake. Clitilu सแ11:เห)

IIIIls.

Timlver.

lake Chibongamoo is studded with numerons low rocky isiunts, expecially along its eastern sile und in the north-enst lay ; $n$ few ure aiso senttered up the western lulf, as un tppurent extension of the ridge forming the southern point. The shores of the lake are low, and ure either formed of solid rock or of large rounded boulders, often found piled up in low walls by the netion on the lake ice. The land rises gently from the enstern side to the luight-of-land some eight or ten miles distunt.

The ridge between the two lakes, on the west side, is low in its southern part, but between the two discharges rises to a height of 250 feet, in a bate rocky hill, ealled Paint Mountain, from the rusty colour of the rocks, due to the decoupusition of iron-pyrites in them. The north-west bay is surrounderl by ligh moky hills, arrunged in sharp ridges purnllel to the direetion of the lake. Theso culminate in the Sorcerer and Juggler mountnins. The former is situated near the end of the point between the two norther'n bays, and is estimated to rise 125 feet nbove the water; the hatter lies a short distance to the norlh of the heml of the nortli-west hay; it nppen's to be somewhat higher than the other, and ends in a shurp) cone, having perpendienlar sides fifty feet high, and is probably compoved of massive diorite. From its resemblance to the tents used hy the Indian conjurors, it has been called the "juggler's house," und is supposed to bo the dwelling pluce of evil spirits. The outline of the hills in this locnlity is shurply serrnted, in inniked contrinst to the rounded outline usually seen in the Iaurentian hills. This difference is prolably due to the nature of the rocks forming the hill, which are chietly a soft, green chlorite or n)tered hornblende schist ensily affected by the wenther. The timber about the lake is larger and better thin at Lake Obntognman. Black spruce predoninate; white spruce, balsam fir, lareh and Banksian pine ilso oceur, together with medium-sized birch, aspen, and n few cedars. 'The higher country at the north end has been mostly burnt over, and is covered with sinall seeond-growth aspen, bircin and Banksiun pine.

From Lake Chibougnmoo to Lake Whihwanichi, the distnnce is four miles, the portage-route passing from the head of the north-west bay up, over a burnt hill about 300 feet, to a snall lake, and thence through three other small lakes, by intervening portages, to Lnke Wah. 
wanichi, which is about 200 feet higher than Lake Chilougnunoo. The country pussed through by the portnge-route is rough and rocky, and, as all the green wood has been burnt ofl, it presints a very barren nppenrunce. Lake Wuhwanichi lies parallel to Lake Chibougamoo. It Iake Wah. is twenty-four miles long, while its brendth varies from half $n$ mile to four miles, with an nvernge of one mile. The south-west end is divided into n number of loug parnllel bays by narrow rocky ridges, which rise from fifty to 200 feet nbove the surfince of the lake. There nre three of these buys on the western side, nnd one on the east side. The former are all about four miles deep, and vary from n quarter to half $\mathrm{a}$ mile in width; the enstern one is nearly six miles lung. From the mouths of these bnys, the main borly of the lake to the northwnrd is less thun a milo wide, for live miles, when it grudu. ally expands and is divided into two bays by a low narrow neck of land comnecting a rocky peninsuln with the mainland. The northwest bay is some three miles deep, and its heul is only a fow miles from one of the southern lays of Lake Mistassiui. In winter the route between theso lakes passes up this buy, aul thence a short dis. tance over low hills to the valloy of a small stream falling into the Mlistassini. The north-east bay is deep, and narrows to less than n quarter of a mile at its head, where the discharge flows out towards Lake Mistassini. Towards its southern end, the lake appears to be shallow, but in the nurrows and northern part it is quitu deep. There are only four or five small islands on the lake. Its water is clear and cool, and it abounds with fine whitefish and lake trout. In its Fish. northern part the inlubitants of tho Hudson's Buy Company post nt Mistassini make their full tishery, ancl take in nets an immense qunntity of lake trout averaging six pounds in weight. On the nortl. enst side of the lake, the country risey gralually some 300 feet to the height-of-land, which skirts that side of the lake at $a$ distance of from three to six miles. In only a few places nlong this shure is the bare rock seen, tho soil being made up of thick lnyers of fine glacial drift, composed largely of débris of the limestone found to the northward about Lake Mistnssini. This forms an excellent soil, as can be juclged tixcellent soil. from the number of large trees upo.2 it. The south-west side of the lake is more rocky. At its southern end and along the narrows, the rocky shores rise abruptly from fifty to 200 feet above the surfnce of the lake. The shores of the north-west bay are low, but the western side of the north-east bay is high and rocky, rising near the outlet 350 feot above the water.

Much of the country surrounding the lake has been burut. What Timber. remains of the old forest, as already stated, is of good size, and trees 
eighteen inches in diameter three feet from the ground, are not uncommon, while the general are rage is larger than that of my district seen northward of Lake Ashouapmouchouan. Black spruce, white spruee, balsam fir, larch, Banksian pine, white birch and aspen grow albundantly on the unhurnt tracts along the enstern shore, and cedar of medium size is found elose to the edg of the water.

Lnke Wahwanichi diseharges into the south-west bay of Lake Mistassini by a small stream four uiles long. In this distance there are a number of suall lake-expansions comeeted by rapids and falls, to pass which three short portages are necessary, the total fall being sixty feet. 'The height-of-land passes close to the river' on the south side, while the country is slighitly brokea to the north.

\section{Lake Misfessini.}

Farly uariatives.

Survey.

Penition.

Size.
Lake Mistassini is the largest and by far the best known lake of the Lalmractor Peninsula. Tales regarding its great size were told by the Indians of the lower St. Lawrence to the earlier pioneers, nul the first explorers of the region brought back exaggerated necounts of the extent of the lake, derived from like sources of information and not from actual observation. Quite recently similar stories excited the imiginations of various writers in the pullic press, and numerous speeulations were indulged in regarding the magnitude of this mysterjous body of water, which, lyy some, was held to be even greater than Lake Superior. When at last a survey of the lake was completed in 1855 , there remained some persons who refused to give up their belief in its supposed grent size, asserting that only a bay had been surveyed and that the lake streteled out indetinitely beyond, far to the north. ward, notwithstanding the fact that branches of the kast Main River rise a sliort distance north ward, and thint othe, branches extend to the enstward, over two hundred miles beyond the northern end of the lake.

Although Lake Mistassini does not reich the size aseribed to it by many, it is still a very large body of water, situated between lutitude $50^{\circ}$ and $51^{\circ} 24^{\circ} \mathrm{N}$, and longitude $72^{\circ} 45^{\prime}$ and $74^{\circ} \quad 20^{\prime} \mathrm{W}$. A straight line drawn from the south to the north end of the lake would run about $\mathrm{N} .30^{\circ} \mathrm{E}$. The lake itsolf has a perceptible eurve letween its ends, with the coneavity of the curve towards the south-east; the shore-line nearly eoineirles with an are of $n$ circle, so that tịe general trend of the lake ehanges gradually from north in the southern portion until at the northern end its direetion is north-east. The greatest length in a straight line, between the heads of the north-east and 
south-west bays, is roughly one hundred miles; the average breadth of the main body is twelve miles, and it varies but little from that mensurement. A low, narrow, rocky point extends out from both the north and soutl ends of the lake, dividing each end into two deep bays. Between the points, and formed by the same rocky ridge, there is a continuous chain of low islands ; these overlap one another, so that only in a few places along the shore is a view of the opposite side obtained. A slight lowring of the present level of the lake would connect these islands and points, so as to form two lakes, as the water between the islands is quite shallow, in marked contrast to the Islands. depth between the islands nnd the mainland on either side. There the depth averages over 300 feet, but in some places exceeds 400 feet. The water is very clear, and the temperature of the main body rarely if ever rises above $50^{\circ}$ Fahr.

The south-east bay is called Abatagush. It is three miles wide at Bny*. its mouth, and from there gradually lessens for six miles to the Big Narrows (Chabatok), where, for about a quarter of a inile, it is not orer two hundred yards wide. Again expancling to an average breadth of nearly two miles, it extends to the south for eleven miles, where it is subdivided into two arins by a long narrow point.

The eastern arm, called Cabistachuan Bay, averages a mile and a half in breadth, and runs south nine miles, and then east four miles to its leud, where a portage leads to the Little Perch River. This stieam drains a number of small lakes to the south-cast, and is used as a route to the hend-water's of the Chief River, the mnin hranch of the Cliamouchouan.

The western arm is larger and more irregular than Cabistacinuan Bny. From the end of the dividing point, where it is two miles wide, it gradually narrows for four miles, so that along the last halfmile it is only about fifty yards across ; this part is called the Little Narrows. Passing the narrows, the bay expands to one mile in width and runs a few degrees east of south for five miles; then it widens out to four iniles, and continues on the same course eight miles further, to the discharge of LakeWahwanichi that comes in at its head. Where the bay widens, there is on the western side, an arm called Sassikan Bay, that runs due north four miles, and is nearly parallel to the main body. Four miles from the head of the bay, a narrow point stretches out three miles from the eastern shore, and almost meets a shorter point from the western side, leitving only a narrow channel between. This point is called Eliquabit, and on it was situated the old King's Post of the North-west Company. The Hudson's Bay Company's post is Trading posts. established on the east side, just inside the Little Narrows. 
The south-west or Poonichuan Bay, for a distance of twenty miles from its entrance, has an average breadth of tive miles, and its shore-line is broken by a number of smaller bays, from one of which a portage of two miles leads to Abatagush Bay, reaching it near the Hudson's Bay post. This portage is murh used, as it obviates n canoe trip of Fisheries. nearly fifty miles, nround the point to the spawning grounds in Poonichuan Bay, where immense quantities of whitefish are taken in nets during the spawning season in October. After the first twenty miles the bay narrows to less than half a mile, and extends in a south. west course for over fourteen miles, a small river coming in at its head.

The bays at the north end of the lake are not so deep as the southern ones. The distance from the end of the point to the hend of the north-west bay is fifteen miles, and its average brealth is rather more than four miles. The north-enst bay extends nineteen miles from the same point to its head, and has $m$ average breadth of four miles.

Besides tho grent bays already described, many smaller ones indent the shores of the lake, especially on its west side, where the coast-line is very irregular and many islnnds oceur.

Character of shore-line.

Surroundiug country.
As a rule, the shore is rocky, with only in steep, narrow bouldery beach, und moderately deep water close in. On the east sile, the shores and islands are formed of limestone, that dips at a low angle towards the south-east; consequently, beaches facing in that direetion shelve gralually into deep water, while those with a western ispect are generally cut off perpandicularly witli deep water close up to them. On the west sicie of the laice, the limestone is only found on the outer islands und points, where similar conlitions exist, but the greater part of the shore-line here, being formed of gneiss, perpendicular faces nee wanting and the slope is more even in all direetions. In some phees no rock is seen, and then the beaches of the islands mod mainland are forned of boulders, often piled up by ice in low ridges close to highwater mark.

As before stated, the esearpment forming the height-of-land pusses close to the southern end of the lake, and continues on in a north.easterly direction at an angle to the trend of the lake, so that it is soon a considerable distance to the enstwarcl as it is followed towarls the north. Tho genernl height of the escarpment nppears to be about 300 feet nbove the lake, but some points may rise to j00 fuet. The only other elevation of any consequence, is a innge of hills that lies about five miles loyund the north end of the lake, and from there appears to trend awny to the westward. its highest point is not over 500 fcet. There is also a 
limestone ridge running along the eastern side of the lake which seldom or never rises 100 feet above the water, but often presents a perpendicular face. This rilge separates Jake Mistassini from Lake Mistassinis. On the west side, the country is generally low and swampy, heing broken by rounded gneiss hills, never orer 100 feet high, and generally less than 50 feet.

The principal rivers flowing into Jake Mistassini, are named the Rivers. Temiscamie, Papnskwasati, Tokwaoioand Wabassinon. The Temiscnmie River is the discharge of Lake Mistassinis, and is the largest stream entering the lake, coming in on the east side, about twenty miles from the north end. It is only two miles long, and as the difference of level between the two lakes is 55 feet, the river descends in a continuous heavy rapid, through a shallow limestone gorge. The Papaskwasati and Tokwaoio rivers are large streams flowing into the heads of the north-west and north-east bays respectively. Both come from the northward, and rise near the head-waters of the Tichagami Branch of the East Main River. A canoe route to Nichicun is said to pass up the 'Tokwaoio River, and to cross from its head to the East MIain River. The Wabissinon River is a smaller stre:m flowing into the lake on the west side, nearly opposite the mouth of the Temiscamie River, and draining an area of country to the north-west of the laxe. Besides these larger rivers, there are numerous smaller strenms that rise in lakes and swamps in the surrounding region; notably the discharge of Lake Wahwanichi ant the Little Perch River, both flowing into the southern part of Abatagush Bay.

The soil of the region about Lake Mistassini is made up of boulder- Grod Soil clay, derived from the disintegration of the neighbouring rocks. Large Laurentian and Huronian boulders, with blocks of limestone, are scattered about in profusion. The finer material of the soil is sandy clay, with a large percentage of finely divided and intimately mixed limestone, especially about the southern and eastern shores of the lake.

The climate of the country surrounding Mistassini is such as to pre- Climate. clude the possibility of its ever becoming an important agriculturnl region, chiefly owing to the prevalence of summer frosts. At the Hudson's Bay post, a most favourable locality, the average temperature of the three warmest months is about $60^{\circ}$ Fahr., lut, unfortunately, no summer passes without severe frosts in June and August, which cause great damuge to the potato crop grown there.

Suow covers the ground from the middle of October, and remains until the middle of May, all the smaller lakes being frozen over during thut period. Owing to its great depth and consequent slow change of 
temperature, the main borly of the lake rirely freezes over before the 20th of December, and it breaks up a couple of weeks later than the smaller lukes and bays in the sprin:; from the sume enuse, the genernl summer temperature of the region surrounding the natu lake is lower than that about the post, and even in the month of $J$ uly, in the swampy lands adjneent, the soil is frozen solid within a few inehes of the surface.

Tinber.

Covering the higher ground tuwards the southern end, white and bluck spruee, balsam fir, Banksinn pine, aspen and white bireh are found, some trees hinving a diameter of eighteen inches three feet from the grouml. Similar trees of smuller size are found along the limestone ridge on the eastern side. On the westeris side, where the Archinan rocks oceur, the soil is scant and sandy, and, in consequenee, the trees are inuch sunaller. They are chietly black spruce and lurel, along with small banksian pine, balsam fir, aspen and white birch. Black spruee and larch alone grow in the swaups, and also form in fringe along the shores and islands of the man body of the lake, where the sweep of eold winds probably inted es with thic growth of other speeies. Cedar reaches its northern limit at the ern end of the lake, where only a few stuntec tre ss tre seen.

Fish. Fish of various kinds and of large size are eatught in alutulanee throughout Lake Mistassini. Lake trout are taken weighing from four to forty pounds, brook trout up to six pounds, whitefish to fourteen pounds, and pike, piekerel, red and white suckers and elub of correspondingly large size. These tisheries would prove of grent value if access to them could be had by milway, as the supply is practieally unlimited here and in the adjoining large lakes.

Animals. Caribon and moose, onee plentiful in the region, are nlmost extinct, and ean no longer be relied on as a source of food by the Indians, who now live wholly on tish, rabbits and the fur-bearing animals. Of these beaver and bear are the most plentiful, the former being still found in considernble .umbers in the small likes and streams tributary to the lake. Plice. bears are common on the extensive areas of burnt lind on all sides of the lake, but most especially to the south-west. Besides these, marten, mink, tisher, otter, lynx and foxes are taken in large numbers, the fur of the marten being partienlarly dark and valuable.

Indians. There are about twenty-tive families of Indians belonging to this post. Very few are now pure-blooded, being mixed with the whites, who have traded in the region for the past one hundred and fifty vears. In the spring all the able-borlied men are employed in the large lark canoes that descend the Rupert River to James bay with the hunt 
of the previous winter, returning with the outfit of goods and provisions for the coming year. The canoes depart about June 20th, and return abeut August 20th. As nearly all the women and children accompany the large canoes in their own small craft, very few persons remain about the post during the summer, and as a consequence parties from the outside find it impossible to obtain guides or other assistance there during that period. Those who remain live altngether on the fish cauglit from duy to day, as only suflieient provisions are brought in to supply the post during the winter and to provide for the men engnged transporting the furs to Kupert House. From these causes, the exploration of central Labrador is attended with many difficulties, especially is the country cunnot be depended on to supply any food luring the suminer months, and consequently provisions to last the entire season must be brought in from the coist, up very rough and rupid rivers at great cost and loss of time.

Lake Mistassinis, as before stuted, lies to the er,stward of Lake Mis- Inke Mistastassini, fron which it is separated by a ridge ff limestone varying ${ }^{\text {xinis. }}$ from two to six miles in width.

The difference in level between the two lakes is tifty-five feet. The smaller lake is about sixty miles long, extending from opposite the north end of Mistassini to a place east of the Big Nnrrows. In its northern part, the leke is about six miles wide and is free from islands or bays, but south of the discharge it narrows considembly and splits up into a number of deep bnys, while its surfuce is covered by numerous low islands. These are formed from limestone reefs running nursiei ts the direction of the lake, ond are most numerous about the ontlet and between there and the Temiscanie River which flows in on the east side sone three miles south of the outlit.

The water of the lake between the rivers is brownish and not clear, wiwh. in consequence of the impurities brought down by the river. In othe1 parts the water is clear, deep and cool. Iarge lish, of the same species as those taken in the great lake, are also abundant here.

The land on the west side of the lake is low, with rocky shores of flut limestone. The country to the eastward is higher, and consists of a platenu formed of limestone, which separates the lake from the Temiscanie River. The fuce of the platenu fronting the lake is steep, und has in places a perpendicalar cliff of linestone rising from 50 to 200 feet ubove the water.

The hills mentioned as bounding the north end of Lake Mistassini, also extenci part way across the nortic end of this lnke, with an interval of low ground to the north-east, , lese a portage of less than two miles 
erosses to the Temiscamie River. This river is the only important one falling into the lake. It takes its rise to the north-enstward along the northern side of the watershed separating it from the hend-waters of the Mistassini and Peribonka rivers flowing into Lake St. John. It passes through Lake Temisennie, a !arge body of water near the heightof-lind, and then flows south-west twenty miles, to within a short distance of the head of Lake Mistussinis, when, instend of entering the lake, it keeps to the eastward of the limestone ridge alrendy ne: $:$ tioned and fluws within a short distance of and parallel to the lake for nenrly twenty-five miles, where it fnlls into a small bay on the enst side.

The elimate, soil and timber of the eountry surroun!ling Lake Mistnssinis are similar to those of the enstern side of Like Mistussini.

\section{Lake Mistassini to the Eust Matil River.}

Ruprert River. From Lake Mistassini, the route to the Enst Main River first deseends $n$ branch of the liupert liver for fifty miles almost due north, and then leaving that stream passes north-westward, through a number of small lakes, to and down a small tributary into the Eist Main River. The distance between the two rivers is fifty-eight miles.

The Rupert River forms the diselarge of Lake Mistassini. It leaves the lake on its west side, thirty-five miles from the hend of the Nortli-west bny. The outlet is at the bottom of a smull bay, where the river flows out, over a ledge of gneiss, forming a small rapid. Here the stream is not over one hundred yards wide, nnd is hemmed

Contracled dincharge of Lake MIista sini. in by rocky banks. This eontraeted diselarge is insufticient to enrry off the waters poured into the lake by the numerous large rivers previously mentioned, and as a consequence the level of the lake rises during the spring, and reaches its highest level about $\mathrm{July} 15 \mathrm{th}$, after which the water slowly subsides. The period of lowest level is about the middle of May, or just before the spring freshets, so thint the lake rises much more rapidly than it falls, making the volume of water in the Rupert very constant in comparison with that of other rivers flowing into Hudson Bay. On leaving the lake, the river tlows almost on a level with the surface of the surrounding eountry, widening out into deep bays and sepurated into numerous ehannels by low rocky islands. For the tirst eight miles of its course, it tlows south-west, or roughly parallel to the shore of the lake, nud so elcse to it that at the end of the distanee $a$ portage of less than 200 yurds leads from a bay in the lake to the river. Below this portnge for two miles, the river continues between roeky banks, with is swift ctirrent, and then flows out into a lake-expansion extending westward more than ten miles, and varying from one to three miles in brendth. 
The river flows out of this lake hy two main and several smaller clunnels separated by large rocky islands. The two main channels are soon joined by the smuller ones, and then form large rivers, separuted from each other by a very large island, and not uniting again for over 100 miles.

The western channel is followed by the Hudson's Bay Company's Two chamels. brigade in going down to Rupert House. This channel is descended in a north-west direction about fifty miles, where the route passes from the western end of an expansion called Lake Miskittenau into a chnin of lakes on the Marten River, a small hranch which joins the Rupert over 100 miles below.

The eastern chan iei forms part of the route to the East Main River. It runs comparativi ly : .ruight for fifty miles, having a general course a few degrees enst of north, and leaving the above-mentioned lakeexpansion at its eastern end, by a number of channels on its northern side. For five miles it is obstrueted by innumerable small rocky islands, Jwlunds in and is so deeply judented with bays, that were it not for the strong current the stream could not be ensily followed. Near the end of this distance the river nurrows to a general width of less than a quarter of a mile and passes over two small rapids between islands. For the next five miles the average breadth of the river is 300 yards, and it flows with a steady, swift current to a small rapid, below which the breadth increases to nearly half a mile, and continues so for two miles to a heary rapid, that falls twenty feet in 200 yards.

The portage past this rapijd is a quarter of $n$ mile long, and runs on the summit of a ridge of boulder-elay. The erest of the hill is about 150 feet above the water, and is so narrow and sharp that there is only room for the portage-road on it.

Below the portage the river is about 300 yards wide for five miles and a baif, with a strong current and numerous islands. It then expands to an average width of half a mile, and is quite deep, with a siuggish current. I'hese conditions continue for seven miles, when, turning sharply westwarl, the elannel contracts and the stream falls twenty-five feet, over a cliute, into the head of Kaclikakatkuaiats or Pinclied-neck lake. This lake extends north-westward Pincleed-neck ten miles, and $i_{i}$ its willest part is aloout two milcs and a half across. Take. The river flows out on the west sidle five miles from the inlet, and thence runs in a westerly direction to join the other main branch, some fifty miles farther down.

From Lak' Mistassini to the first portage, the country surrounding the river is very tlat, with no hills over 150 feet high. The river apjears to have no clamuel proper, merely tilling the depressions and fol- 


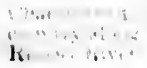

I. wing the general slope of the country. The islands, shores, aus $n$ reater part of the high lnnd are rocky. The clepressions where they ref not occupied by swimps, appear to be tilled with brol:en rock und $\mathrm{b}$ metrs, while the finer materinl of the drift has to a great extent been carried away, not enough remaining in muny places to fill the interstices between the henped-up, boulders. The boulders and broken rock are ulso profusely sentterel over the rocky hills and in the river-bed. What soil remains is poor, thin and sandy, supporting

Timber.

Burnt coluitry,

Portage-route ixetweril Ril| vert ant Gast Main rivers. only a seant stunted forest growth of black spruce, lurch, aspen, and white birch. These trees never exceed forty feet in height, or ten inches in diameter. The underbrush in the low-lying ge tions is

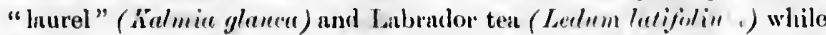
the higher ground is covered with white reindeer moss. The growth of trees in this region is exceedingly slow, ns onny be seen from the length of time required to cover areas hurnt over yeurs ago, and where now only a scattered growth of black spruce and Banksian pine is springing up.

Below the first portage, the river flows in a valley eut trinswersely through severnl ridges that appear to run enst-north-east and westsoutli-west. These hills, as the river is descended, rise gradually from 100 feet to 100 feet in the neighhourhoor of Pinched-neck Lake, where they oceupy both sides of the lake. Along this lower part of the river more than half the country has been burnt orer, thus remoring all the trees and regetable soil, and leaving only the late rock and senttered boulders, giving to the region a very barren, desolate alpearance.

Tho portage-route between the Rupert and kast Main rivers lenves Pinched-neek Lake at its wester'n end, and there passes, two miles up n small stream through four small lakes $(1,2,3,4)$ conneeted by short portages. Then a portnge of 200 yards lends to lake No. 5. This is one mile long, and is connected by a portage of 500 yards with a larger take No. 6, which drains into another small branch of the Rupert. This lake is full of small islands and has numerous little hays. It is followed three iniles end a half northward to its dischinge, whero a great mass of boulders, 200 feet wide, separates it from lni.s No. 7 . The outlet of this last lake is close to the inlet, and is sail to flow westward through a chain oi small lake's to tho Rupert River.

Passing northwarl for a riia and a lacif, the route then turns westward for one mile, into a bay, and then northward again three-quarters of a mile, to $n$ portnge of 800 yarde: which leads to lake No. 9 , which is about $n$ mile long and three-quarters of $n$ mile wide. It crossez this lake to another portago of 800 ynrds through a swamp, ending in a 
slightly larger lake, No. 10, which is followed N. N. F. one mile and a quarter to its heal, where a portage of 400 yards passes over a houlder. ridge 200 feet high, and ends in a broal shallow stream. Another branch of the Rupert River, which is one mile and a half to tho eastwaril, flows out of a large lake, No. 11. The western end of this lake is erossed, and a short portage made a if . . mall stream flowing into it. This strean is followed nortliwned ubon wo miles and then turns direetly west for unother two miles, . here ! short portages, with " pond hetween, leat to lake No. 1: 11.: inke is followed north-west for two miles, when n portage of $-v 0 \quad \cdots$ is made to lake No. 13, at thr, hend the Kawnelagami or Clemater River, n small branch of

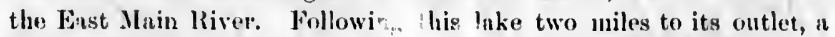
portage of half a mile ends at the han! of the eastern bay of Clearwater Lake.

This lake is roughly triangular in shape, having east, west, and north ("lonwate bays, with minor ones. Its water is hrownish, elear, and moderntely Lalis. deep. Islands are numerous especially at the end of the north bay, where the slrore-line is roeky and irregular. From enst to west the lake meitsures about seven miles, and about threo miles and a half firon north to south. Two sunll lakes with narrows between, leal from the north-east corner of the north bay, to a long lake lying to the west ward, about four miles from Clearwater Lake. The outlet is on the enst side of the north bay. It is very small and narrow, and as it turns off at right-ingles to the direction of the buy, cannot be seen until entered.

Leaving the lake hy the outlet, the river flows directly east for two miles and a half; then it bends sliarply to the north-west, around a long rarrow point and enters a snall lake. Following this lake northwarl for two miles, a short portage is made past usmall rupid at its cliseharge, after which the course is west, for two miles and $n$ half, through a sniall lake-expansion to another short portnge past a fall of eight feet.

The river thenee flows nortly ward in a shallow, sandy ehannel for four miles to another small like, a mile and a half long, with a rapicl at its ontlet. The river, now about twenty yards wide, Hows with a sluggish current in a very crooked ehannel through un extensive swamp, until it empties into Tide Lake on the East Main River. The distnnee between the iast two lakes in a straight line is five miles, while by the river it is considerably more than double that; the genernl course is W. N. W.

From Pinehed-neek Lake to Clenrwater Lake, the eountry passed Charneter of through by the portage-route is broken by roughly parallel ridges of country alloug 
rocky hills. These hills rise from 200 to 500 feet above the surrounding water level, and appear to run nearly north-east and south-west. The hills of each chnin are usually connected with one nuother by sharp ridges of coarse boulder.clay. T'hese ridges are highest and thickest on the south-west sicle of the hills, where their material seems to have been accumulated in the len of the rocky obstructions to the ice during the glacial period. Like tho sharp ridge described ut the first portage on the hupert River, these ridges are largely composed of boulders and semi-n yular blocks of gneiss with very little finer material, and havo the same characteristic narrow erests, sloping on eitler side.

Between the ridges the lower ground is ofton swumpy and covered with a network of small lakes. From a rocky hill, 250 feet high, nt the portage between lakes No. 10 and No. 11, over tliirty of these small lakes were counted, filling the valleys on all sides.

Forest fires. The greater part of the region is clestituto of forest trees, these having leen removed by frequent extensive fires. 'T'he bare rocks of the hills are thickly strewn with boulders, often of grent size, while the valleys are filled with the same, often to a depth of many feet, and without suthicient sand or clay to conceal the space between them. Usually a thin covering of vegetable nould is found on the heaps of houlders. In a few places on the inkes, sandy shores are seen, bit the grwater part of the shores und islands are formed of solid rock o: of henped up boulders.

Sunall trew, The unburnt forest is made up of small trees never more than thirty feet high nor exceeding ten inclies in dinmeter. Black spruce is the most common, and on the lower ground grows thickly together, while on the hillsides it is only found in open glales. Larch occurs in the swaups, and there grows to a lurger sizo than any of the other trees. In albindance, Banksian pine ranks next to the black spruce, but is gencrully small. A few small trees of white birch are seen in clumps on the higher ground surrounding the lakes, and are accompanied by an ocensional clump of struggling aspen never over four inches in diumeter.

High rillges. From the top of a hill rising 350 feet on the north-west sicle of Clearwater Lake, in uninterrupted vicw of the surrounding country was obtained. To the sonthwad, the high hills of the rilges already passel are seen extending north-east and south-west. To the eastward, they appear to have about the same altitude as those seen along the route, but to the westwarl they are considerably higher, and some of them, ten or fifteen miles to the south-west of the lake, inust rise from 500 to 800 feet above the general level. Their tops are bare, and large 
ind-

est.

patches of snow were observed on their northern sirles on July 14 th. Northward, the country is not so broken, and none of the ridges rise nlyove 300 feet, while the valleys are bronder, with more swanjy land and fewer lakes. Further awny in this direction, there is unother range of higher hills extending east-ant-west beyoul the kast Mnin River.

The country surrounding the diseliarge of Clearwhter Lake is at tirst Flat comutry, rolling, but after prssing the small lakes it becomes flut, and the river winds through an extensive swump, with only a few isolnted rocky hills rising from it. The swampy lands we thickly eovered with simull black spruce, lareh and Banksiun pine, the trees inereasing in size as the Bust Minin River is upproached. Boulders aro less numerous, and there is a considerable nunount of tine yellow sand urrunged by the river in small terices along its banks and about the small lakes.

On $n$ island in Clearwater Lake the sril was found to be fiozen solid, at a depth varying from six to nine inches below the surface.

\section{East Main Riser.}

The Hudson's Bay post at the mouth of the kist Mnin River, on Prosition of the east shore of Jomes Bay, has I:een deternined by W. Ogilvie, the numth. 1).L.S., in 1890 , to be in latitude $52^{\circ} 14^{\prime} 45^{\prime \prime} \mathrm{N}$. and longitude $78^{\circ}$ $29^{\prime} 15^{\prime \prime} \mathrm{W}$.

The river, at its mouth, is a mile and a hulf wide, but is obstructed by a number of siund and shingle shoals, bare at low water, with shallow ehunuels between them. The river-lanks are low and sandy. As the river is ascended, the sand gives place to clay, cut in places by the river into steep faces. The Hudson's Bay Company's post is situated Hudsom's lay on the south sile, three miles from the mouth, where the banks are Company. about fifteen feet high. The river opposite the post is $n$ little under $a$ mile wide. Three large islands of clay occupy the southern side of the river for two miles and a half above the post, with a narrow, shallow ehanuel between them and the inainland on that side. Opposite the head of the upper islund a small river, called Fishing River, fulls into the main strenm from the north-east. Tide-water extends seventeen Head of tide. miles up the river, and for this distance the course is about due enst. The banks are low, formed of stiff blue elay, and much of the lund on either side is low and swempy. The river gradually narrows from $a$ width of three-quarter's of a mile, above the islunds, to about a quarter of $\mathbf{a}$ mile at the head of tide, where a small stream, called Coldwater River, comes in from the south. The current, from the mouth to the 
hend of ticle, varies from two to frur miles per hour. Along the riverbotton there is an abundant growth of mediun-sized white and bluck sprence, Inlsam tir, nsyen and balsum popjor.

Inmedintely uhove the heul of tide, the chancter of the river changes to a succession of rupicls, anl for the next six miles the lanks become incrensingly higher, with steep cut fuces, showing elny overluin by sund, or sometimes con'se boulder-clny, with un ocensiomn] exposure of rock coming up from benenth. The bunks here rise from fifty to one hundied feet. The villey besones grulually narrower and the rapids heavier, until in the upper mile and a lunlf the river is only about 100 yards wide and fnlls seventy-fivo feet through $n$ shnllow, Buvil tinges rocky gurge, cnlled linsil Gorge. The gonerul conrse of this stretch is N. $75^{\circ} \mathrm{F}$. Inumedintely ubove these rapids the river ngain cloanges to " ųuict-flowing strenm about 600 yurds wide, with low lanks and ״ llat country on either side.

Two miles ubove the hend of the gorge nnd twenty-five miles from its mouth, the river divides intu two brnuches, which ulpear to be nearly efmul in size, one coming from the north-enst, tho other from the enst, the latter being the one surveyed. From the Indiuns nt East Inin post, it wa lenmed that the north-enst brunch is callerl the Straight River Opinace or Stmight River, nud that its volumo is about two-thirds that of the other branch. It is much the ensier river to uscend, being free from long rap'ds and portnges, and takes its rise in n numlier of large lukes between the hend-waters of the kist Branch and those of the Big River.

Above the forks the course of the east branch is due enst for seven miles, while its width varies from 600 to 800 yurds; the current is sluggish and the banks low, but they rise gradually as the strean is uscended, so thant in the last mile and $n$ half of this course, they are from fifty to seventy-five feet nbove it, and present cut faces of stintified sands and clays; or of houlder-chy. The river here narrows to $n$ width of 300 yards and becomes rapid.

Tisking linlls. At the end of this course there is a sharp lend to the south, and a quarter of a mile above the bend is a eloute of twenty feet called Talking Falls, with strong rapids below and nbove it. From this chute, the river, with several minor bends, has a genernl south-enst course for the next six miles, being almost $n$ continuous rapid, with nbout 120 feet fall, including a chute of sixty-five feet, called the Island Falls, at the upper end. At this ehute the river is divided into a number of narrow eliannels by several small rocky islands. The hanks along this portion of the river are not high, and the country appears to rise with 
the river. There is a portnge of 400 yards on the south side past the chute, und two miles ulove it a smull river, culled the Mlinkinntin, comes in from the soutl.

Above the chute, the river ngnin expands to nu avernge wilth of 600 yarks, and tlows from S. $60^{\circ}$ k., almost on $n$ level with the surmounting country, for ten miles between low banks of elny eupped with s:tnd. The timber continues the sume as before, but is somewhut smuller. The river now narrows to 250 yards, and continues with suall rapids northwarl for a mile, between rocky hills, then turning enst, it widens slightitly and is less mpid for another unile, to the foot of a narrow rocky ehannel ealled Clouston Gorge. This gorge for a mile Cloustom nnd $n$ lulf from its mouth is perfectly straight, nud is never more than liorge" 100 feet winle, nurrowing in one pluce to thirty feet, with rocky silles that rise almo:t perpendieulurly 100 or 200 feet ahove the river, which rushes through it in one grent rapicl, fnlling in the interval 105 feet.

Aluve this the course changes to $\mathrm{S} .70^{\circ} \mathrm{W}$, and the river becoming slighitly willer, mounts in the next three-rfuarters of a mile twenty foet to the foot of a roeky isliunl 1200 ynrds long with " unrrow ehunnel on either side. Through these chunnels the river fulls over 100 feet in $n$ succession of chntes. For three-quarters of $n$ mile alove the hend of the island, there nre a number of small islands with mpids between them.

To pass these obstruetions it is necessary to portage canoes and land portage. outtit three-yuarter's of a mile through a deep swamp, with only one spot sufliciently dry to allow the londs to be laid down. The portage begins inmedintely below the gorge on the south side, aud ends in a small bay near the head of the islunds.

The river is now found flowing nearly at the level of the surrounding country, with a sluggish current between low banks that becone more and inore sandy. The general course of the naxt stretch is N. $60^{\circ}$ E., and the distance twenty-two miles, the brendth os the river varying from $a$ quarter to three-quarters of a mile, with an averay of about lulf $a$ mile. The limit of balsam poplur is renched near the upper end timit of of this course, a fact due probably to the ilsenee of low dicy banks, inlsam along the river above. The other trees se smaller, and white spruce beyond this becomes scarce. White birch is now a common tree, and Banksinn pine is found wherever second-growth timber occurs on sandy soil.

Continuing on the snme course for three miles and a half, the river again becomes rapid, and flows in a valley which at first is about 200 yards wide, with scarped sundy banks which rise about 150 feet above 
it. Soon the ehannel nurrows to less than $100 y_{i} \cdot 1 \mathrm{~s}$, and the sandy Conglomerat. banks give place to rock ns it enters Conglomerate (korge. In the Gorge.

Charactur of the lower rivere.

Marine ter. raceix.
Countiy surrounding the lower river.

Tinlser: upper lialf of the distance the fall is very steep, the river pussing with a suceession of ehutes, in small channels between n numler of small, narrow, rocky islands. The tutal fall here is over 100 feet, including three chutes of twenty, ten and thirty feet respectively.

From the head of this rapid, the river bends to the south for a mile, then S. $30^{\circ} \mathrm{W}$. one mile, and ngnin south another mile to it ehute of ten feet. $\Delta t$ this last full, the character of the river und surrounding country ehanges. From its mouth to this point the river has llowed in a shallow valley, nearly on the surface of $a$ number of hrond terraces of strntified sand and eluy, arranged one abovo the wther. Where it descends from one level to the next, the river lus eut $n$ valley back into the sands and elnys of the upper terrace until the underlying rock has been reached, over which it falls in a suceession of rapicls uncl elutes, often hemmed in by steep rocky walls.

The terraces are composed of marin deposits hid down during the depression of the land at the clow of the glaeinl period, when the level of the western side of the Tabralor Peninsula wis over 600 feet lower than at present. Farther up the river, marine dejosits are wanting, and the surfnce material is formed of unstratified, contse boulder clay. Owing to the absenee of termees, there are no murked drops from kevel to level, but rather a more or less gralual slope of the whole country, while the river, withont even a shallow valley as in its lower part, flows almost at the level of the eountry und follows the general slope, exeept where liverted by roeky rillges that cross its eourse obliquely in several places. In the lower part the river is obstructer only by islands at the various falls, and there are few roek-exjosures elsewhere; while in the upper purt roeky island: are everywhere numerous, and long stretalies of the shores are also formed of rock.

The surrounding country, in the lower purt, is generally lat and often swampy, but there is a marked alsence of small hakes though about the upper part of the river some are found in every valley between the low, rounded, roeky hills that sharneterize this region. The soil in the hilly country is seant and poor, heing composed wholly of boulder-elny, often with very littlo finer material. Tho climute also appears to be more tigorous than it is nearer the sea-const, and the timber is much smaller, consisting of the following species arranged in order of nbunilanee :-Black spruce, Banksian pine, larch, balsam fir, white birch and a fow stunted aspens. The lureh grows to the largest size, a few trees being upwards of twelve inclies in dianeter nenr the bnse; the other species seldom or never latve $n$ dianeter 
exceeding nine inches, and in the upper part of the river are only found growing thickly on the lower ground, about strenms or lakes, with the hills only partly covered by small trees of black spruce and Banksian pine. The white spruee does not grow beyond the limits of the deposits of marine sands along the Fast IIain River.

Above the last-mentioned chute, the next course is abeut due enst, Character of ineluding two short sharp bends to the south, in a distnnce of eight river aluove miles. Along this course, the river flows in a sluallow, rouky channel, (iorke. about a yuarter of a mile widle, through an almost that region, broken only by a fow low, rounderl hills. The deseent is sharp, there being five rupils and two chutes of six and eight feet, separated hy short intervals of swift current. At the upper rupil and chnte, the river bends to the sontl-enst, for another eight uniles. In this interval it is broken into several ehannels by a number of large low islauds, strung out along the entire distnnce. The current in these channels is moderate, with only one small rupid near the upper end. The Kausahiskau River is a small strean, that falls in on the south side near the foot of this rapid.

Further up, the river for twenty-five miles, forns a long gentle curve, bending first slightitly north and then south of east, so that a line joining the ends of the curve would run east-and-west Here, stretehes of yuiet water connect five short heavy rapids. Rocky islands are unmerous and the shores are low and in places rocky, but more commonly swampy. To the south, there are hills running in ridges roughly parallel to the course of the river. These eulminate four miles up this course, in Fhit-topped Mountain, that rises nearly 500 feet nbove the water-level. The rest of the range rarely exceels 300 feet, and 250 feet may he taken as it: mean height above the general level. Similar ridges of roundenl hilis are seen to the northward, but they do not nppenr to he as high as those on the other side and they are inore distant, lenving a wide margin of low swanpy laud between their hases and the river. The trees on these hills have almost all been burnt recently, swamp. leaving only a fow patehes of green wood. Where the rapids oceur in the river, the hills elese in on either side.

Medium sized rivers fall into the main stream at the seeond, sixtl Wabistun and and tenth mile of this course. The first and third are enlled respee- Akuatuge tively, Wabistan and Akuntago, both coming from the southwarl; the second is called the Wubanisik, and comes from the northward. It is much larger than the others, being about $20 \mathrm{U}$ feet wide, at its month, with a slow eurrent.

The main river abeve bends to the south-east for eight miles, and then to the east agnin for eight miles. The country and river have much 
the same character is the part last describel ; the current beingr somewhat stronger, with three small rapids. At the upper end of the hist course, there is a small stream, called the Clearwater River, that comes in on the north side, and flows in a wide straight valley from $\mathrm{k}$. $\mathbf{N}$. E., a continuation of the valley in which the mnin river flows below. The Indians who hunt in this region, say that it is only a laalf day's journey from the mouth of this stream to a inrge lake on a brunch of the Strnight liver.

The lireat Bencl.

Broken countey.

Whirl|̣kol.

Countryajov the cirent Bend.
Turning now sharply to the south-west, the main river, which has had an averuge brearth of over a igurter of a mile, enters the (irent Bend, und contrnets to nloout 100 yarls, and for tho next lifteen miles is nothing hut " succession of henvy rmpils and elutes. Its banks nre high and roeky in most pluces is it brenks the range of libls before mentioned on the south side. 'The surrounding eountry is much rougher than any hefure seen, with rounded hills, from 200 to 300 feet high, nranged in elose parallel rillges. The lower six miles of the river ne particulnty rough, and as the perpendicular elitts on both sides renler portaging impossible in mony places, it is with dillieulty that this part of the river is passed with eanoes. At one place nbout three miles from the foot of the rapids, there is a sharp lend to the northwarl, and the water rushing lown is defleeted hy a sharp point running out from the east side at the bend, which eanses the greater volume of the water to enter a smull bay, where a great whirlpool is formed. It is stuted that muny yeurs ago two largo eanoes belonging to the Hudson's Bay Company were drawn into this whirlpool and all on board drowned.

At the upper end of this south-west course, a small stretm, called Misintawagamisistic River, comes in from the south-west, nnd it is believel that there is a portage.route 1.0 it, past the rajpids below.

Turning now to S. $40^{\circ}$ E. for there miles, the river gradually widens, and passing two smull rapids, again hecomes ensily navigable. It flows, with a sluggish current, in th chanmel 500 yards widle, anul only slightly below the level of the surrounding low, flnt, swumpy country. This continues for fifteen miles, the general course being N. $60^{\circ}$ i. Two sinall rivers come in nlong this course from the north. At the upper end there is a fall of ten feet, alowe which the river, eontinuing along the same course for fourteen miles, has a similar s] uggish current, with the exception of one small mupid at, the hend of two large islands. The surrounding country remuns low ar' swanpy, except in the vicinity of the mpid, where a low range of hills passes close to the river on the south sile. 
Abuve the two islands, the river ngain turns to the east, and flows with a remarkably straight course for nineteen miles. The hills on either side here close in nud narrow the valley, through which the river runs at $n$ uniform rate of about four miles per hour, in a shallow channel wernging 400 yaurls in wilth. The likls, as a rule, do not rise much nbove 200 feet from the water, and only an exceptional we renches 300 feet. They are arrunged in rilges neurly parallel to the course of the river.

Along the upper three aniles of this course, the channel narrows to Narrow chanalout 150 yarls, and the current increnses where a descent is made nel. through a narrow cut in the liills. There is now a slarp bend to the south and then to the south-west for a mile nnd $n$ half, as the river cuts tlirough a rnuge of hills, witls a fall of twenty-five feet, including n cliute of tifteen feet. At the bend, a small river comes in from the north enst.

The surfice materinl eovering the hills along the last two courses is soll. generully thin, ant is in places composed largely of boulders, often of large si\%, with the spnces between them only purtly filled with tiner muterial.

The forest, for the most part, is mude up of small second-growth Forest. black spruce, Banksian pine, lareh, halsan fir and white birch, with a few aspen poplat.

Alwe the bewl, the river ngain enters wother valley between parallel rivges. Its courses nre: lirst, enst five miles, then N. 60' li. four miles, and agnin east eight miles. The average willth is again abont 400 yards, with a swift uniform current and only one smull mpicl. As this portion is ascended, the country becomes rougher, and the hills rise Roupher with steeps slopes, from 200 to 400 feet above the water. The grenter comntry. part of this region lats been recently burnt, only putches of blackened soil being left to partly cover the rocky hills, while innumeruble Inoulders are seen scuttered everywhere over the surface. A river nbout three clanins wide at its mouth eomes in from the south it the end of the first course.

Another sliarp bend of three and a half miles to the west of south Prowner now follows, and in the lower mile and a half the river pusses through fiorn. n narrow rocky elinumel with perpendicular sides, enlled Prosper Gorge, and fulls in a succession of ehutes and mids over one hundre: feet. 'To avois this olstruction, the river was left four miles and a lanlf below the bencl, by a portage of three-quarters of a mile, which pusses over a ridge and ends about the middle of the west side of $n$ lake three miles long and three-quarters of a mile wide. This lake discharges from its 
uorth-east eud hy a small st renu, nearly a milo long, into a seemd lake one mile long hy bulf a mile wide. Crossing this lake, the sumll crooked strenn by which it diselunrges, is followerl some t vo miles to where it falis into the mnin river, two miles nlwove the bend, nul thus above tho elutes und rapids. There is only $n$ slight fall from the "yper latke to the river, mul as a consequence, when thore is a freshet in the math strenu, the wuter frum it hacks up into the lakes instemel of dischurging from then.

Abres this portuge tho river barones very croved. It lirst llows from the east for a mile and a laiff, then trom soutl-enst one mile, $N$. $80^{\circ}$ F. three miles, $5.30^{\circ}$ W. threwe-quarters of a milo, s. $45^{\circ} \mathrm{W}$, a mile and a balf, and linulty s. $^{4} 5^{\circ}$ L. six miles, where it lenves un expunsion wer one mile wide, and full of largo islands, at the fout of the lioss (iorge, running south.

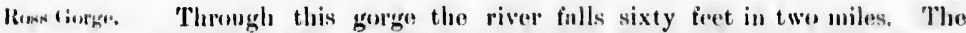
portuge past it starts from a sm:til bay on the west sile, and is divided into two parts hy a sinall pernd. The first part is 300 yomis long amd rises about 150 fine ; the second is three-pluaters of a mile in length, pussing over a sterp ridge of boulders and ending in as small strem which enters the river a shert distance above the hend of the chutes.

Alont lanli a mile bolow the upper pont of the portuge, a river tulls in on the nortls sids. It thows in a doop, rocky valley muning east-

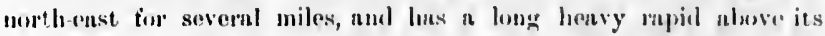
montls. Its sjoc has been estimated at abont one half that of the main brunch, and it has been enlled lioss Rivire. Alwove the garge the main river is split into a number of small chamels by serral low Ianke Nowas. islands. These islands form a delta in the enstern end of Iake Nasaskllimat, kuaso, which extends to the westwad six miles, and is n mile and $n$ half neross in its wiclest part. The river passess only through the east

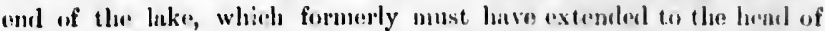
the portage. the portion now oreupied by the delta linving lueen fillod up with alluviom breught down by the river. surroumling the lake are rocky hills that pise from 200 to 100 feet abowe its surfuces. The arenter part of the aljacent endutry has beon burnt over reently.

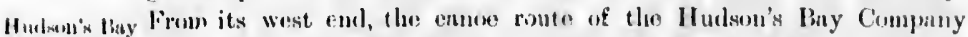

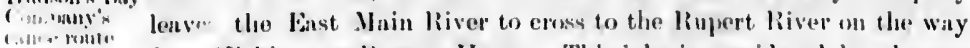
for a Siehicun to Rupert Itouse. This bake is considored ly the enphinees of the eompuny to be sitnated half way between these two fi: ces. The Indimes who hunt in this region are in the hathit of $\mathrm{cm}$ gregating here and on the lakes at the fout of tho hage island above, to met the canoes going to and returning from biujert Ilouse. 
Ahove Lake Nisaskunso the eharacter of the river and eountry again Character of

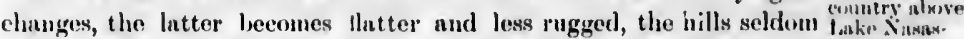
rise orer 150 feet above the river, and the rilges are farther apart, knasis with swamps and small lakes filling the hroad slanllow vallegs between then. The river flows almost on the surfiee, and is often divided into several chunnels by lawe islunds. Simall lakes and bays also brunch off on cither side, so that it is ditlicult to tell when a trilutary river finlls in.

In this manner the river continues for nine miles, when it becomes (irand I wuxt. divided into two unin elannels hy (ipand Island, fourteen miles long and tive loroul. Th" nowth channel is more than twice the size of the somth one, and it is further suh-divided, especinlly in its lower part, hy lange islands. 'The south hronch, from the foot of the islond, jasses suntlawarl onut five miles and widens out into two lake-rxpansions witlı numerous bays, all laving an mast-and-west direetion. Into the soutl-west bay of the upper lake, tive miles from its outlet the Clearwater Rives enters. 'This is a small strean flowing out of a large lake of the same name on the portuge-route from lake Mistassini.

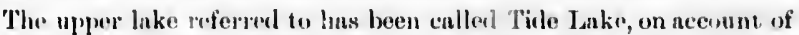
the deposits of mud that cover the shores and islands up to freshot mark of the river, giving the lake the appentance of a tidal lny at low wates.

For seven and " half miles ahove the lu of Grund Tsland, the river avernges 500 gards in width, hot is shet and much olstrueted by sandy shonls. Its direction is ngain must ad nt the heal of this conrse is the junetion of the Tichegmui Riv. This st.ean tukes its Tirlangani rise, aceording to the Indians, to the soutl, ast, near the heal-waters River. of the rivers Howing into the north on if Lake Mistassini. In volume, it "ppears to be nbout two-thim hat of the main branch, and it has a heary rapid at its mouth.

There are only a few fumilies of Indang who hunt along the lower furlims of the part of the East Mlain liver, there being a loug interval from Lake Bant Mium Nasaskunaso to below the Great Beml, that is totally uninhalited. Owing to the numerous rapids and chutes, this river alweve the mouth of the Straight liver, is not used as a highway to the interior, and unly one faunily uscends it alnove that stream. Previous to 1889 , there wre three fanilies who hunted in the neighbourhood of the Wabamisk lliver, but during that winter, with the ey. ption of one womnu and a suall boy, these all perished hy starvation or cumnibalism. In 1892, Finime. the seene of this trngedy was found at the mouth of tlut river, luut, nothing being known of such an vecurrence, it was only remarked as 
Increane of fur-luturing auiuals.

Fish. unusual that Indians should leave their tents standing, and their household effeets seattered about.

Above Lake Nasaskunso, from the many old camps seen aing the river, there must be a number of fanilies who hunt in this vicinity, and who in the summer deseend to Rupert House, by the portage-route to the Rupert lRiver. Owing to the absence of hunters along the greater part of the river, the fur-bearing unimals are rapidly increasing, and beaver signs are quite common; bear tracks are also numerous in the burnt regions. Not a sign of earibou was observed from Lake St. John to James Bay, and these animals seem to have been totally exterminated in the rmgion about Lake Mistassini and from therg westwarl to James Bay, being now only met with to the north and north-east of the liast Main River.

Fish are found in abundance in every lake and river, throughout the region. The following kinds were taken in the net alo'ig the last Main River:-Whitetish, pike, piekerel amb suckers. In the lower parts, where the lanks and bottom are formed of clay, sturgeon are taken in abundance by the Indians; and from the meuth to the tirst fall, and in the tributary streans, sinall whitefish anil sen-trout ascend from the sen in large numbers, from about September lst, until the river is closed by iee. 'lrout nrenlso eaught in the mpids of the upper purt of the river.

\section{Upler East Matin River.}

Three miles alove the Tichegani, a rocky ledge crosses the river dingonally, causing a low fa!l, where the survey of the lower part of the river in 1892 began. Ahove this fall the river hends sharply northward for a half mile, and then about south-east for three miles, to the head of a long, but not strong rapirl, which oceupies the upper half of that distance. The direction now changes to north-north-enst for two

Kawsatstakau miles and a half to the mouth of the Kowntstakau Kiver, a large branch River. $\quad$ coming in from the northward and entering the river from a considerably higher level by a heavy rapid or low chute. Accorling to Iniinn estimation this stream carries alomt one-sixth of the water of the unin river. Immediately nhove the forks, what appenrs to he another hranch, also broken by rapids, is seen on the south sille; but it is only a cliannel passing on the south side of a large island or islands, and separating from the main ehannel above the rapils and portage, five miles further up. The north or main chunnel contracts from $n$ width of nearly half a mile, helow the island, to less thun a yuarter of a mile, and the current is quite strons, with two rupids, the lower of which 
two miles nbove the foot of the island, is a half mile long; but the upper one is short and steep, with a tremendous rush of water, the river falling eight feet in one hundred yards. The portnge is on the north side, und is enlled the Sunday Portage.

$\mathrm{Up}_{\mathrm{p}}$ to this portage the conntry surrounding the river is low nnol almost Character of that, with only a fow isolnted liils that seldom or never exeed one murrounding hundred feet in elevation above the genernl level, while the river flows only slightly below it, in a shallow valley from 300 to 1000 ynruls wide, linving in most eases low sundy bunks never more than seventy feet high. The sund and gravel of the banks ure made up of moditied boulder-clay arranged by the netion of the river. On either side of the river, the soil appears to be light und sandy, und, as small fires only iave traversed this region, the timber has not been destroyed, but thickly covers the eountry, the t ees cucurring in the following order of ubundance:-blnck spruce, B.als inn pine, lareh, balsam tir, white birch und aspen, the last heing exceedingly rare and only founl along the river in low strnggling elumps.

Above Rumlny Portige the river flows directly from enst for the next. foar and $a$ hulf miles. The average width is nenrly 400 yarls and the eurrent is strong, with two rupids one and two miles above the portuge, the upper one being so heny that canves must be lighteneal to nseend it. The portage pust it is alout 200 yurds long, on the nork sicle. At the foot of the lower rapil a small branch from the south joins the river.

The river now turns sharply to the nortliward, and, flowing from that direction, in the next mile breaks through a low ridges in a shullow, narrow, rocky channel, and falls tifty-five feet from tho level above, the descent taking the form of a heavy rapil. To pass this the Poml Poud Portag". Portige is male on the east side. To reach it a small strenn is nscenled about 200 yards and from there 200 yarils purtage up " low hill leuls to a small pond; crossing this, a rough roud over boulders aud through swanps for lialf $a$ mule ends at $n$ smull channel of the river, behind an island. From bere the course is $\mathrm{N} .45^{\circ} \mathrm{E}$. for a mile, nnul then in a general direction $\mathrm{N} .45^{\circ} \mathrm{W}$. for five miles, with many minor bends and erwoks. About one mile up this course, what appenrs to lse a linge branch comes in on the east side, but it is probully only a channel lenving the main stream several miles above, and so forming $n$ large island. The river continues nbout « quarter of $n$ mile wide, is stallow, and flows with a strong stealy eurrent, brenking into small rnpicls at points and narrows. Another small stream comes in from the northward at the upper end of the course. Now agnin benling 
enstward a mile nbove, the river widens out into a snull lake, so crowted with low islunds that its limits enunot be seen.

Chardetier if exinutry nimese light.

Ileight aluse. min-inevil.

Hill.

fire.

TaWN" (") try alxust Shiarprock Portage.
From Sumdny Portage to this lake, the chaneter of the river lanks and surrounding eountry is similar to that before deseribed, the bunks being low and the comntry nearly flut, with isolnted hills aul rucky ridges genemuly under 100 feot, and never exeecling s:0 leot in (levition,

Owing to un unfortunute nevident on the Koksank liver, through the upsetting of one of the ennes, the haromoter widings were lost, and only n few bookerl in the survey note-lonk remain. Firom the menn of these datu the beight of the river in this vicinity is roughly fouml to be 1400 foet nlwe sen-livel, which tugrees clusely with the suplesed differenee of level letween here and Iake Mistussini, that

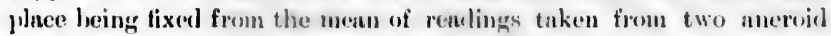
burometers and extonding over severnl montls.

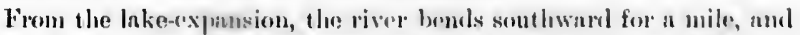
then directly east, flowing from that direction four miles, from the bise of a high roeky hill on the north sicle, whicls forms n part of $n$ runge extending trom beyonel the north side of the lnke to flue gast. warl. These bills are rery steep and roeky, bring formed of the homblende-grmute that now takes the place of the softur achists mol gneisses of the llat country leshow. 'They rise from 400 to sul foet above the river.

Before reaching the foot of the hills, the river locenues semewhit wider and tlows lxetween low banks of sand and gravel with a moxlonto euserent in a shallow channel, much obstructed wils low sondy slomls. Much of the surrounding country lins bewn lume over, nod in part is covered with small second-growth tress, Inoksinn pine then predomimutiug. Whore unhurnt, the forest is somewlat Inrger mol thicker than that seen lower down; this is owing mest likely to " leeter soil.

At the foot of the hill the river ngnin almutly bends to the sult

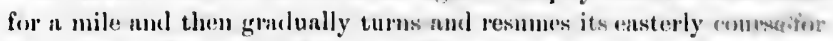

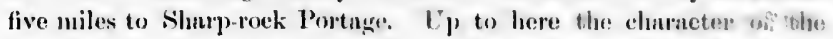
river is similur to that lower down, being flat and slom wible $n$ molerate current broken ly two short rapicls, the lower an the busel and the upper two miles alove it. The mange of hills on the north side continues along the river and crosses it at the portinge, but so much lower that at the erossing it is little over a liumireal foet high. To the southwarl the comntry is momost flat mul heoth sjolos have been almost totally burnt over, the fire on the north sile being most recent. 
Sharp-rock Portage is on the wurth side and is about 400 yards long, the lower half passing ower sharp vertienl hancis of hornblende-sehist. 'llhe river talls ter foet over the same ledger.

Alwe the portage, the course is $\mathbf{S}$. $60^{\circ}$ F. for thee miles to nuother portanco, 200 yards long, where a chute of eight feet occurs. Hetween the portages the lanks nee low, with traces of a ternee twenty feet hish on the south side.

Finther vph the river flows from the north for n mile, and then from Wide walley

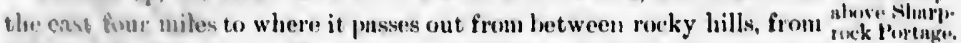
$20(0)$ to dove feet high. From the last portuge to this point, the that valley is somewhat wifler, nul the shonllow clannel of the river is whitructed by a umuber of islands and gravel shouls, the current here bxing very strong.

After the hills ure entered, the course is south enst for two miles, and then north for two miles. Nong the south-enst eonrse the river is less thun 300 yards witle, but on the northern course the wilth is irregu. litr, varying frou 300 to 800 yarils. 'Tlue current everywhere is strong.

At the bend, a medium-sizel strenm comes in from the south, Mink Chute. and perhins nuother on the north sile a mile betsw. Another besul to the mastwarl, and a mile of river, leads to Mlink Clunte, thirteen feet ligh, passerl ly a short purtnge over the rock on the enst sitle.

The eountry surrousting the river from Sharp-rock Portnge to character of

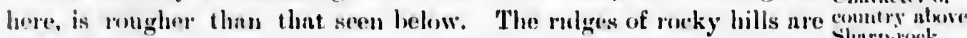

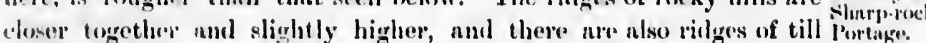
"Ipparntly arruged roughly parrallel to the direetion of the glacial stria, or s. 70 II. On hoth sides of the river there lave beren extonsive lires and litte of the original forest remnins. The trees continne similur in size and numbors to those described below, angen being the only che now nlsent. Terrnees of suml and gravel are sresi on loth siles up to thirty thet alove the water, und ircasimal cut-latukn of beulder-elay are inticel, where the river his maten awhy purts of the low hills of drift mentioned nhove. The rocky hills ne molerately strewn with isoulders.

Mink Portage is followed closely by another short one, on the south sider, past a chute of nine feet; and then for tive miles the river tlows rapidly letween low and rocky banks to Clamusal Portage. 'This port- Clanue age is on the nowth site, and is about 800 yarts long, terminnting in l'artage a suall channel above a fall and behind several rocky islands. $U_{p}$ to the head of the jslunds there is but one small rapid in the next mile, whereas the main or south channel is a succession of chutes and heary ripjids for nearly two miles. 
From the head of the isinnds, the river widens to over hulf a mile and flows evenly from the north-east between low sandy banks, over which eun be seen high hills in the distnnee to the north-enst, enst, and soutli.enst.

Four miles of quiet water is followed by $n$ shallew, that rnpicl, full of small rocky islanels and large boulders. After a sharp bend the course is to the north for $\mathrm{n}$ mile, and then north-enst for two miles to nnother small lake-expansion. Along the two last stretches, the river, con. tricted to less tlun 300 yards, flows between rocky lanks, mud is grently obstructed l,y rocky islauls and ledges, which enuso short heavy rapids with very swift water between them.

Charieter of country alkest ('humin! lortinge.

'Tiulver.

Almundanes of till in $t_{1} \mathrm{j}_{\mathrm{r}}$ rengions.
On the south side, at the head of the rupids, n conieal hill rises 350 feet above the river. From its top a good, unobstructed viow of the surrounding country muy bo obtnined, ns it is totally burnt over ..nd bare. To the north-enst, the river is seer. flowing with but one bend, through $\mathrm{a}$ wille, straight valley, surrounded by low hills. These on the north sirle are about 200 feet high, and are armuged in close, conpact ridges, everywhere woll worded. On the south siln, there is n wille valley filled with small lakes, that separates the conical hill from a higher range parallel to, and forming the north wall of the river-valley. The highest of theso hills rench and may exceel 500 feet. 'They are bare and rocky, and have a very harren, desolate appenrance, lue to the absence of green wools; fire rather than unfaviumble elinutic conditions being the eause, as some of the hills have small patches of unburnt trees upon their summits. The sides and tops of these bare hills are strewn with innumernble boululers of all sizes, from inusses several tons in weight to sunll gravel, but there is not much of the finer muterinl on the upper parts.

In the river-valley, latch is seen eighteen inclies in diumeter, and black spruce and balsnm fir of twelve inches, are eummon. The only evilence of an appronch to larren ground, is afforded by the thinning out of Ledlum and Kalmia and the sulstitution of whito reindeer moss as undergrowth, while the trees begin to grow wider apart with frequent open glades.

Above here the cha monter of the river changes somewhat, long islands of till are numerous, and there is n markerl absenee of terraces or strutified deposits, these being replaced by banks of irregular height and outline, formed by the river eutting through the low lenticular hills of moderntely fine boulder-clay. The islnnds formed of similar materials, appear to be hills of the same description, and have only been separnted from those on either shere by shallow clannels eut between them. For three miles and $n$ half the river is over half $a$ mile 
wisle, but is very shallow, and its hottom is thickly strewn with houlders and suhungular blocks of gneiss and granite, very similar to tho rock. masses seen in pluee in the vicinity. The descent, hoth here and in the expansions further up strenm, is constant and quite steep, cuusing the water to flow with a very swift smooth current, which is more diflicult to asceul in ennes than broken wator, where the eddies and quiet places behind boulders and other obstructions are avilablo to rest lofore the ennemen attempt other short aseents; whereas in the stenly, strong, smoutl current no such clunces to rest occur, mul every foot gained must he held.

Bemhling from mast to north-enst, the river contrinets to ubout 300 yurls for two miles, anil again expands at the heml of $n$ large island, at the encl of the course. Two small strenss enter from the north, ut the upper and lower ends of the stietel.

Turning eastwarl agnin, the hanks hecome more rocky and irregulur, with numerous small lonys, so that the hremlth of the strenu varies from 300 to 1200 feet. There is a small rapiel on s mile and a half up, nul at its hend a lurges strenn named the Misnak River enters on the Minank River. north sicle. From this place the general course is $\mathrm{N}^{\circ} 50^{\circ}$ F. for six miles, to the Cuscudo Portnge.

Immerlintely ubove the $\mathbf{N}$ isusk River, the main streum is divided into two equal elannels by a large islabel. The north channel is followed east for two miles unil then south for three-quarters of a mile to the heul of the islant. The whole distance is a continuous mpirl, culuninating on the south benil in a chute of fifteen fret, which is passel by a portnge of 800 yurds on the east sille. There is a steep rise of one ilany rapicl hundred feet at the lower end of this portuge, from tho river up thisut a cut-bank of till, to the level of the rilge above. From the head of the island, half a mile of quiet water lends to nuother purtuge, on the west side, 1000 yurts long, past henvy rupids, followed hy small rapicls for half a mile, to the foot of another large island. following the smaller and southern channel, another half mile of stiff eurrent leads to the Ment Portage, 300 yards long, on the west side. Another short rapid is then pussed, to the head of the island. The rise in tha river has now brought it to a level with that of the surrounding country, whiels is broken only by low ridges of till and an oceasional rocky hill, seidlon exceeling one hundred feet, so that the surface presents the appenrunce of a very rolling prairie, especially to the soutl.warl, where most of the trees have been burnt. Evelywhere the surface is covered with innumerable boulders anil subangular blocks of granito and gneiss. 


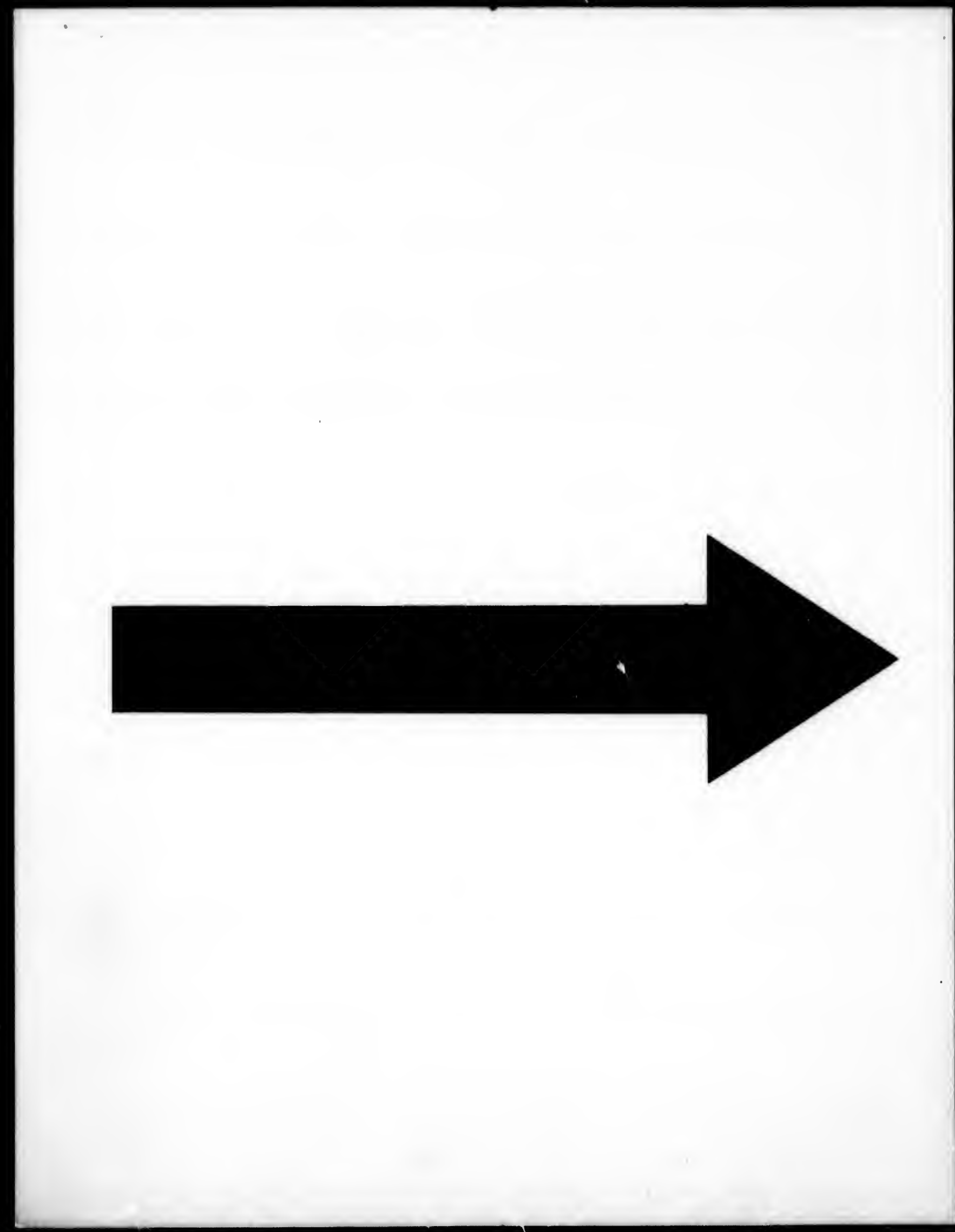




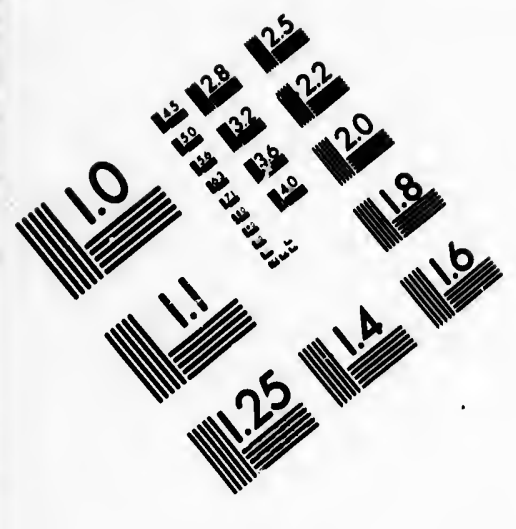

IMAGE EVALUATION

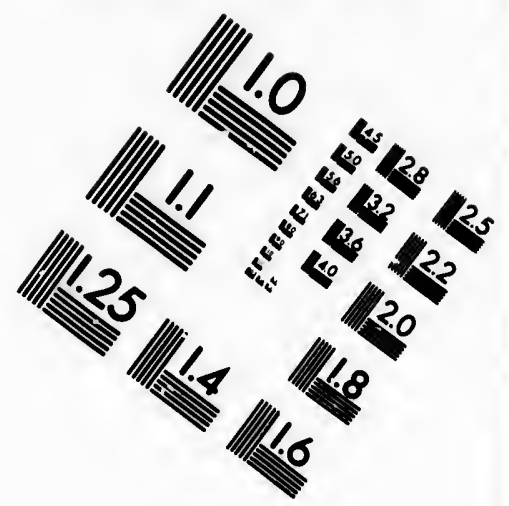

TEST TARGET (MT-3)
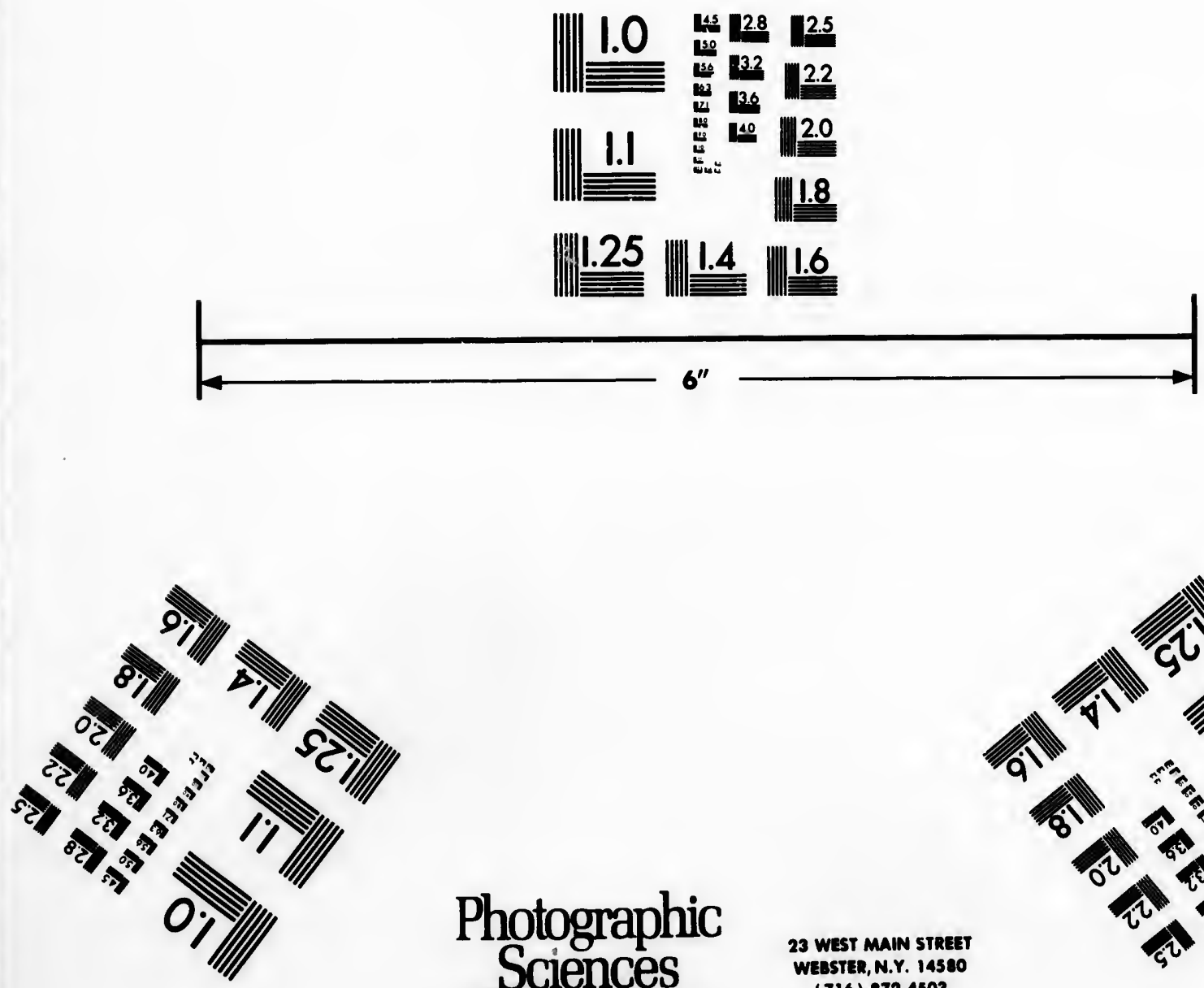

Photographic Sciences

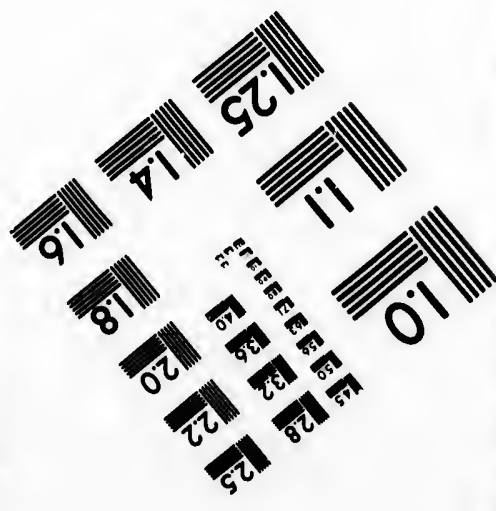
Corporation 

Character of theriverbelow Long Portage Creek.

River above Long Portage Creek.

Character of country above Long Portage Creek.

Having now reached the general level, the character of the river changes, and for the next nine uniles, to Long Portage Creek, it is a succession of lake-expansions, connected by short rapids. These expansions are broken by deep bays, running between the low ridges, and often pass by small narrows into other lakes, the country being now covered by a perfect network of small lakes and watercourses, lying between the low hills. The general course is slightly south of east. The first lake is about one mile and a half wide, and it is two miles from the head of the island to the next narrows and rapid. The water is shallow and there are several large islands. The rapid above is half a mile long and is followed by a smaller lake, one mile long, to a very heavy rapid, passed by a portage of 900 yards on the south side. Above, there is quiet water for half a nile, and then rapids, half a mile long, are followed by swift current for two miles to the next lake-expansion. This lake is also full of large islands, and a narrow channel on the north side leads into a chinin of lakes extending over ten miles to the north-east and branching off into numerous other snall lakes on either side of the main chain. A mile and a half of steady current leads to another sinall lake, into which the Iong Portage Creek flows.

Here the main river takes an abrupt bend to the south-west, and after a short sharp rapid is ascended is found to widen out into a string of lakes with numerous deep bays, for about fifteen miles; it then breaks into a heary rapir two miles long, above which it continues south-west for a considerable distance, when it again turns eastward, passing behind a high hill some fifteen miles south of the forks.

The country about the forks is very similar to that already described, consisting of a series of low ridges of boulder.clay, arranged in broken roughly parallel lines, coinciding with the direction of the glacial strix, or $\$ 0^{\circ} \mathrm{W}$. The general leight of the ridges is about fifty feet, while the highest rarely exceed one hundred feet. Betwcen and paralle] with thein are innumerable small shallow lakes, irregular in shape and full of high islands formed of mounds of till. These lakes are joined together by small watercourses, following each valley, and the different chains often have lateral connections where an interval occur's between overlapping ridges. The only conspicuous landinark in this vicinity is the rocky hill situated about fifteen miles south of the forks; it rises about 500 feet above the general level, and is unconnected with any other high land. To the south, south-east, east and north-east the horizon is bounded by chains of high hills, at a distance ranging from twenty to fifty miles from the forks. 
The East Main River was explored only as far as the head of the Upper Fiat two-mile rapid mentioned above. The route to Nichicun leaves the main stream at Long Portage Creek, where the river is still a large stream, being nearly 200 yards wide at the rapid there, with an uverage depth of three feet. According to information received from the people at Nichicun, the main stream, although large where the route leaves it, soon splits up into numerous branches, none of which are of any considerable volume or length. The river bends to the south-west for some twenty miles, and then turns eastward again along the northern foot of the mountains that here form the watershed between the Rupert, East Main and Big rivers, flowing into Hudson Bay, and the Peribonka and Outardes rivers, emptying into the St. Lawrence.

Misawau or Long Portage Creek, from its mouth to the portage, Long Portage following the streain, is thirty-three miles long; but in a straight line Creek. the distance is twenty-four miles, and the general course is slightly north of east; the difference in length being due to its crooks and turns. From the East Main River, for the first six miles the course is north-eust, the stream here consisting of a number of small irregular lakes, joined by short stretches of river. At these narrows the river is generally about one hundred feet wide, with a moderate current and deep water. This course terminates with a rapid of six feet fall, passed by a portage of 400 yards on the north side.

For the next four miles the river flows from the east, with a uniform breadth of one hundred feet. The current here is strong, with three short rapids, the upper passed by a demi-charge. Next follow small lake expansions and swamps for four miles, in the same direction, with one short rapid near the upper end. Still further up, the river is crooked, and forms a reversed curve, ending at the forks, four miles beyond, where it splits into two equal branches, the route following the eastern one.

Above the forks, the average breadth continues to be about one Rocky liundred feet, and where small rapids or swift current occur the Portage. water is so shallow that wading is rescrted to in order to pass loaded canoes. For nine miles from the forks, to the Rocky Portage, the character of the river is constant; it has in most places a sluggish current, with small shallow rapids at long intervals. The banks are low, and the inmediate surrounding country swampy. The portage is 500 yards long, and follows the side of a hill on the south shore. The river here passes through a narrow valley, between high rocky hills, and in so doing falls thirty feet. The valley widens above the portage, and the river again flows from the east, in a low valley, 
filled with numerous sinall lakes on both sides, connected with the river. As the Long Portage is approached, the river becomes more rapid and shallow, and it is only with great difficulty that loaded canoes can be taken up it. It is left at the Long Portage, where it turns to the northward, rising in the small lakes in that direction, at no groat distance above this place.

Character of country about Long Portage Creek.

The country surrounding the lower part of this stream is almost flat, and is traversed by ridges of till never more than fifty feet high. These gradually rise until the forks are reached, where they average 100 feet. From the forks to the Rocky Portage the hills recede, leaving a low swampy valley through which the river flows sluggishly in a channel but little below the general level. At this portage the first rock seen in place along the river occurs. The stream here falls over ledges of red granite as it passes down a narrow valley between two steep rocky hills that rise abruptly to 300 feet.

From here to the Long Portage the valley is again wide and strewn with numerous small lakes and swamps, connected by short channels with the main stream. The hills on either side nov have an average elevation of 300 feet, and often show rocky faces.

Over one half of the country surrounding the river has been burnt, and is now covered only with low shrub and reindeer moss. Owing to the want of forest growth, the innumerable boulders and angular blocks of all sizes stand out in remarkable distinctness, giving to the hills the appearance of gigantic plum puddings. These blocks and boulders with the amount of drift are a feature of the country, the drift along the lower parts of the stream being so thick that it covers all the underlying rocks which can be determined only from the profus of angular, untravelled blocks scattered about. On the very sunmit of the high granite hill on the north side of the river, at the Rocky Portage, there is a perched boulder over ten feet cube. Its corners are only partly rounded. Numerous other large boulders are scattered over the highest parts of this hill, and so thickly are they everywhere strewn that one might walk for miles over the country in almost any direction without touching the soil with the foot. The trees along the river are small and somewhat scattered, with little underbrush, the ground being covered with white moss and arctic berries. Black spruce predominates, with larch in the swamps and Banksian pine on the higher lands. There are also a few small white birches and balsam firs. One very small clump of aspen was noted.

Long Portage The Long Portage is two miles in length, and from the creek passes S. $30^{\circ} \mathrm{E}$. over a ridge 200 feet high, terminating at a small lake 150 
feet above its lower end. The lower half is burnt bare, but there is at its upper end a thick growth of small black spruce, with a few Banksian pines and larches. This portage is over the watershed which divides the creek from the waters of the Pemiska Branch of the East Main River.

From the portage at its upper end, a small shallow lake is followed by a portage of one mile to a slightly larger shallow lake full of great blocks of granite, which in turn is followed by another portage of a half mile, ending in another small lake, triangular in shape. The route to here has been due east; it now turns south, and in a half mile leaves the lake by the stream flowing out, with a short portage past a small rapid at the outlet, and so into Opemiska Lake. The country surrounding the small lakes consists of low ridges of till from fifty to one hundred feet high, well covered with small black spruce and larch to the exclusion of all other trees.

Opemiska Lake is six miles long, with an average breadth of three- Opemiskn quarters of a mile. Its longest axis lies nearly east-and-west. The water is clear and shallow. There is one deep bay at the north-west end, full of small low islands. The shores are generally low and sandy, and the surrounding country is also low, with sinall ridges of till. Ten iniles to the south-east of the lake, a high isolated hill rises about 500 fee above the general level, forming a conspicuous landmark; is regarded by the natives as the dwelling place of spirits, and on that account given a wide berth. The country about here is unburnt, and is well wooded with black spruce and larch, the former constituting over ninety per cent of the trees. The only other tree met with is balsam fir, found sparingly about the shores of the lake.

The Pemiska branch of the East Main River, flows out on the south Pemiska side, about the middle of the lake, and leaves it with a heavy rapid. Its volume here does not exceed one-quarter of that of the river at the mouth of Long Portage Creek. The route follows the lake to its eastern end, where it ascends for two miles a small river about fifty feet wide and full of rapids, with a total fall of twenty-five feet. Three short portages arc necessary to pass the strongest parts of the rapids. The country surrounding the river is low, rough and rocky, with a superabundance of loose blocks and boulders, many of great size. Two were seen resting on a rocky knoll at the head of the rapids; the larger is more than twenty feet cube, and the smaller more than fifteen feet cube.

The river ends in Wahemen Lake, another large body of water Wahemen stretching to the eustward, divided by long, low ridges of till into Lake. 
Patamisk Lake.

a bewildering number of deep bays. The route closely follows the southern shore, and, passing a small narrows, ends at a portage four miles from the outlet. The portage is $\mathbf{1 4 0 0}$ yards long, and joins the river above a heavy rapid. From there to Patanisk Lake, at its head, the distance is eight miles, in a general east course. The river passes through five small lakes, each full of deep, narrow bays, and connected with the next lake by short, rapid stretches. The numerous bays and the small size of the strean makes it very difficult to follow the route without a guide.

Lake Patamisk is reached by a portage of 1000 yards past a rapid in the river, which is here not above twenty-five feet wide and very shallow. This lake is the largest passed through between the East Main River and Nichicun. The route traverses the lake to the end of the north-east bay, seven miles from the outlet. Large deep bays indent both sides, and the main body is filled with large islands, which obstruct the view and hide the real size of the lake. A deep bay extends westward from a point half a mile above the outlet on the south side. The limits of the shore on the north side could not be determined, nor those of a wide deep bay on the south-east side, but the lake evidently extends to the foot of some hills about ten miles from its entrance. The water is very clear and in places deep, but as a rule shallow.

Watershed between Fast Main and Big rivers.

Character of country at the watershed.
A portage of 500 yards leads from Patamirk Lake to a small shallow lake one mile long, with a portage 200 yards from its cast end into another smaller lake half a mile long. The portage from this lake crosses a low bouldery ridge and ends in Kawachannack or Crooked Lake, about twenty feet below the level of the last, draining into the Big River; so that the last portage is over the height-of-land batween the Big and the East Main rivers.

The country surrounding the route from Lake Openiska to the height-of-land is every where the same, consisting of ranges of hills of boulder-clay seldom more than' 100 feet above the general level. These are separated by wide irregular valleys filled with small lakes, so that fully one-third of this area is covered with water. An occasional rocky hill may be seen rising from beneath the masses of till, sometimes attaining a height of 300 to 400 feet. Immense numbers of boulders and loose angular blocks continue to be scattered in wild profusion everywhere. As the height-of-land is approached, the forest growth becomes smaller and less thick, and is made up almost wholly of black spruce, the largest of whiclı are about six inches in diameter; the only other tree is the birch, which forms less than ten per cent of the whole. Where fire has passed, a number of years elapse before the 
second growth of black spruce springs up, whioh it does then only in a thin straggling manner.

Crooked Lake, stretching N. $60^{\circ}$ E., is nearly five miles long and Crooked averages one mile in width, with numerous small lateral bays, which Lakt. give it an irregular outline. The western part is filled with islands. The nortl $\iota_{1}$ shore is almost wholly burnt and bare, while small black spruce and larch cover the hills on the south side. The country becomes higher and rougher, witı more rock showing up from beneath the drift. A short portage at the east end leads directly into the south-west branch of the Big River. This river rises about / sixty miles to the south and south-west, where it drains a number of lakes lying along the northern slope of the mountains, close to others emptying into the hend-waters of the East Main River to the west and those of the Outardes River on the south side of the mountains. The watershed in consequence runs east-and-west here, on or near the fifty-second parallel of latitude.

The route enters the river at a bend, where its course changes from Big River. north to east. In size it is nearly as large as the East Main River at the mouth of Long Portage Creek, being in the rapids about 200 feet wide, with deep water flowing four or five miles an hour.

From the portage, the river flows $\mathrm{N}, 60^{\circ} \mathrm{E}$. for eight miles, to the foot of a sharp rocky hill 280 feet high. It flows almost level with the general surface, and, like all the streams of the region, is made up of a series of small irregular lake-expansions, connected by short narrow stretches of swift water. Even in the widest parts a moderate current is appreciable. At the toot of the hill, the river enters a large lake that stretches several miles to the eastward, and has several deep narrow hays separated by low parallel ridges of till. This body of water is called Big Back Lake. The river flows only through its Back lakes. north-west part, leaving it half a mile below its entrance, and then bending sharply to the west, passes close to the foot of the hill, and enters Back Lake. From the top of the hill, looking north-west, the country as far as could be seen in that direction appears as if overed by a great number of small lakes that lie parallel to, and are separated from each other by low ridges running east-and-west. These are not separate lakes but deep bays of either Back or Nichicun lakes, these two bodies of water being separated only by a small short rapid.

This rapid is five miles from the foot of the hill, through Back Lake, but the irregular shore-line of the lake must be at least fifty miles long. From the hill, the irregular outline of Nichicun Lake is seen Lake Nichistretching away toward the north for a great distance, bounded by ${ }^{\text {cun. }}$ 
bold rocky hills often rising from 400 to 500 feet above its level. Through bleaks among these are seen the valley's of the outlets of tho lake. Toward the east, the country beyond the Back Lakes is seen rising in ranges of hills from 300 to 800 feet high, of sharper cutline than the ordinary Laurentian hills. These bound the horizon to the south-east and south, and are said to form the north-east flanks of the central mountain range of Labrador which extends along the watershed in a north-east and soutl-west direction from the bend of the East Nain River to about thirty miles east of Nichicun. Thence it gralually sinks and is lost in the general level of the country, which nust there be over 2000 feet above sea-level. To the south-west and west the country is lower, with isolntel rocky hills rising above the level of the low ridges of till.

The only signs of an approach to the barren lands is the lack of trees on the tops of the highest hills, but the rest of the country is well wooded

Forest fires. where unburnt. Fires have destroyed great areas of forest in this region. They are sometinses caused by lightning, and when once started, burn with surprising rapidity, travelling as quickly through the dry, white reindeer moss as over the grass of the western prairies. The Indians too are often accountable for these fires, most of which, it is likely, have been started by them, as they use smoke for signalling from great distances. Islands in small lakes are usually fired for this purpose, but brands are often carried by the wind to. the mainland, and thousands of acres burnt over in a short time, the fire continuing until the first heavy rain and often breaking out afresh when dry weather again sets in. At times the Indians purposely burn large areas in order to -epare the ground for bear-hunting; for within $a$ few years after a fire, in this region, the surface becomes thickly covered with blueberries and other small firuits, forming feeding grounds for bears during the autumn inonths.

Climate. The climate at Nichicun does not permit the growth of grain, and in the small patch of land under cultivation at the Hudson's Bay post, only potatoes are grown, and these rarely if ever ripen properly, the tops being frozen early in September, or even i:1 August. Summer frosts are also common and often severe.

The following information concerning the trees and shrubs about Nichicun was obtained from Mr. Jos. Iserhoff, who is in charge of the Hudson's Bay post there. Black spruce is found on the shores and Trees. islands of the lake in abundance, and trees that will square six or seven inches for twelve feet, are not uncommon. White spruce is not plentiful, and is seen only in certain places along the sides of the lower hills. Balsam fir is common, and is found everywhere near the water, some of 
the trees growing as large as the black spruce. Banksinn pine is very rarely seen, its eastern limit being defined by a line drawn nearly northand-south through the Long Portage, beyond which line to the eastward, only a few straggling trees are found, while on the wost side it is very abundant. White birch is common about the sides of the small hills, especially whero fires hnve passed long ago; but no trees of a size sufficient to afford bark for cnnoe-building are found in the vicinity, and all the bark is supplied by way of Hudson Bay. Although common about Lake Nichicun, a short distance to the north and north-east, it is very rarely met with. Small straggling aspen and mountain ash, found in little clumps at wide intervals, complete the list of trees of this interior portion of Labrador. Small fruits are very abundant, but the prevalence of early summer frosts seldom allows the fruit to ripen.

Lake Nichicun is 1760 feet above sea-level, and is a very irregularly size and ontshaped body of water, with numerous deep bays. It is so plentifully line of Lake strewn with islands, that it is ditficult to form an iden of its size; many of the islands are large, and one, Big Island, is six or seven miles long antl about two miles wide. The greatest length of the lake is from east to west, about thirty niles, and at the western end a narrows continues on into Little Nichicun Iake, which extends several miles farther. At its widest part the lake does not exceed ten miles across, and it is so obstructed with islands there, that it appears much less. The average width is about five miles. The numerous long points stretching out from both sides, together with the islands, make it almost impossible to pass through the lake without great loss of time unless with a guide. One of its deep bays, to the south-west, heads within a short distance of the river, near the portage from Crooked Lake, and advantage is taken of this to pass the rapids in the river when travelling from Nichicun to the East Main River. The shores are low and covered with rows of boulders shoved up by the ice. The country surrounding the lake is rough, and covered with numerous ridges of boulder-clay. To the north-west, north and east, there are high rocky hills rising from 300 to 600 feet above the lake. The islands are mostly portions of boulder ridges, but some of the larger are high and rocky, especially Big Island. The water is very clear and moderately cold. As a rule, the lake is not deep and in many places it is quite shallow, with large boulders rising above the surface. It discharges on its east side, the river flowing out by three channels. The two southern ones soon join, but the northern channel does not unite with the others for nearly fifty miles, or until the river changes its course from north-east to westward.

The Hudson's Bay post is situated on an island a short distance Nichicun from the inlet of the lake. This post has been long established, pro- Hudson's Bay bably before the beginning of the present century. No record of post. 
the date is known, but in 1840 , a Mr. John Spencer was in charge, and mado a sketch map of the surrounding country. At that time an outpost was situated at Lake Kaniapiskau. The map is now in the oftice of the Geologicnl Survoy, and is very interesting, as it shows the watershed between the St. Lawrence, Hudson Bay and Ungava Bay. At present the post consists of five small log buildings : the master's house, two servants' houses, a small store, work-shop and powder magazine.

Cance route to The supplies for the post are brought in from Rupert House by three Hudkon lany. large canoes, each manned by six Indians. In order to reach Nichicun in time to prepare for winter, the canoes leave the lake at the first open water, or about, June 15th. The trip to Rupert House is made hy the route to the East Main River, down it to a stuall lake called Nasuskauso, thirty miles below where the route to Mistassini turns off. From this lake a portage-route through a long chain of lakes is followed, and the Rupert River renched a few miles above Lake Nemiskau, about 100 miles above Rupert House, the river being descended to that place. The total distance from Nichicun to Rupert House, by the route followed, is somewhat over 500 iniles. It takes two weeks to go down with the canoes partly loaded with the furs taken during the previous winter, Rupert House being renched about July 1st. Three or four days are spent there, and then the return trip up strenm is commenced, and by working throughout the long summer days, from daylight to dark, Nichicun is again reached between the 15th and 30th of August. On leaving the const, the canoes are londed down to the gunwales, but before their destination is reached over a quarter of their londs are consumed. This gives some idea of the difficulty experienced in supplying an inlund post like Nichicun.

Sustenance of the inhabi-

Sufficient provisions cannot be brought in to support the people at tants. the pest, who have thus to depend largely on the country for food. During the summer they subsist almost wholly on fish, caught in nets in the lake, and are often for inonths without small luxuries such as ren, sugar and tobacco. During the winter the living is better, for then, besides the small rations of flour and other provisions, they are able to obtain abundance of fresh meat. About a dozen caribou are killed by the people of the post during the year, besides heavers, . musk-rats and benrs. Usually rabbits and ptarmigan are abundant during the winter season, and are shot and suared as required. In some years, however, both rabbits and ptarmigan are not plentiful, and caribou are scarce. During such seasons the food supply is very limited, and great care must be taken to prevent starvation, especially as the Indians are affected by the same circumstances and flock to 
the post for relief. A supply of salt fish is laid in, every autumn, Fish. in case of need. The fish are principally whitefish and lake trout, caught with nets late in the autumn on the spawning grounds in various parts of the lake. The articles of trade in the store embrace sinall quantities of cloth, clothing, tea, sugar, tobacco, powder and shot.

There are about thirteon families of Indians who trade at this post, Indiaus. but this does not represent all the people inhabiting this portion of the interior, as a number of families prefer to descend to Rupert House and trude there, bringing in their year's supply themselves. Others living to the southward, who formerly traded at Nichicun, now descend the rivers flowing into the Gulf of St. Lawrence, and do their truding at Bersimis, Seven Islands, or elsewhere along the north shore.

These Indians belong to the western Nascaupee tribe. They speak a dialect closely resembling that of the Montugnais. The men pre of medium height and fairly good physique. Some are tall and well developed, but the average height does not exceed five feet seven inclics. Like other Indinns they are sinewy rather than muscular. As a rule, they are less cleanly than the Montagnais, taking little care of their clothes or persons; and they generally swarm with vermin. Owing to the small numbers of caribou killed in this region, the natives are forced to clothe themselves in garments bought from the Hudson's Bay Company. They live in wigwans covered with cotton, as they cannot get either the deer-skin used in the north or the birch bark covering of the south.

The hunting grounds of the Indians of Nichicun extend from the Hunting height-of-land on the southward, to the head-waters of the Great grounds of Whale River on the north. To the eastward they hunt as far as Lake Indinns. Kaniapiskau and down its discharge about fifty iniles. There appears to be quite an extensivo aren between their eastern boundary and the western limit of the hunting grounds of the Hamilton River Indians, who trade at Northwest River post. There is also a large area without hunters on both sides of the Koksoak River, from where the Nichicun Indians leave off, to where those from Ungava begin, as no signs of Indians were seen along that stream for nearly 200 miles. The greatest number hunt to the westward of Nichioun, or about the head-waters and tributaries of the Big and East Main rivers.

The presence of a trading post in the interior of Labrador, such as Necessity of a that at Nichicun, is at present absolutely necessary to the Indians trading postin inhabiting that region, and it is doubtful if the country would support half the present population without it. In seasons of plenty it is not necessary, the Indians transporting their furs to some point on the 
coast, and returning inlund with their next meason's supply, but in seasons of starvation, without the aid furnished by the post, a majority of the people would die. The grentest number of denths from starvation occur about the Rupert and Kast Main rivers, in the country midway between Nichicun, Mistnssini, and Rupert House, where the distance is too great from uny of these posts to olutuin assistance during the winter. So grent has been the mortality in this region, during the last fow years, since the extermination of the caribou there, that the country is nearly depopulnted, and $n$ supply of provisions is kept by the Hudson's Bny Company at luke Nemiskau ou the Rupert River, to relieve the Indiuns in extreme cases o. necessity. Frem the above, it will be seen, thint although at present the populution of the interior is small, it nppears to be in excess of what unnssisted nature would sustain with the present habits of the Iodians.

Fiducutionand The Indians of Nichicun all read and write the syllabic characters religion of the invented and taught by the missionaries of the Church Mission Society, and letters written on birch bark with charcoal are commouly seen on the portages along the varions routes. The missionaries luve also a number of books printed in these charncters, including a selection of hymns and almost the whole of the Bible. These books are greatly prized by the natives. Although nominally Christians, their religion is greatly mixed with pugan idens, and as their opportunitics of acquiring a knowledge of Christianity is limited to the short stay every summer at Rupert House, it is no wonder that they retain many of their old beliefs. The visit to the const is the occusion for the celebration of marriages and baptism.

\section{Route from Nichicun to Lake Kaniapishau.}

Big River below Lak Nichicun.
We left Lake Nichicun by the middle discharge, on August 5th, 1893. The general direction of the stream is north-east. For two miles, to the first portnge, its brendth varies from 50 to 300 yards, with swift water in the narrows. The shores are very irregular and are made up of low ridges composerl almost wholly of large boulders, with little fine material. Along the river and in the small bays, are distinct traces of a terrace twenty feet above the present water-level. When the lake stood at that height, it must have covered an area nearly twice as great as it does at present, extending over a great deal of land now dry, more especially to the south and south-west.

The first portage is on the north side, following along the summit of a low ridge for 300 yards. The river here falls eight feet over a rocky ledge. Two other short portages in the next two miles pass 
similar smull falls over ledges of rock. The thisd portage terminates in $n$ bay of a small lake-expansion, the river taking " short turn towurd the north and falling into the lake nbout half in inile beyond the portage. The next portage is three miles below, the river in the interval varying from 50 to 800 yards in wirlth, with numerous small decp bays running off on either side. Into one of these sunall bnys the south discharge fnlls. The portage crosses a narrow point, around whieh the river, greatly enlarged, rushes in is henvy rapill, obstructed by many huge boulders. On both sides of the river here are sharp Character of rocky hills rising from 400 to 500 feet uhove the water. Below the river and hills the valley widens out, and the surrounding ridges are low, country. with isolated rocky hills rising at intervals above them. For the next eight miles the course is north, and the river alternates from rapid nutrows to small lake-expansions covered with little islands and broken by narrow deep bays.' In the narrows, the river breaks into small rapids full of boulders, and has a strong current even in the widest expansions. A suall lake is then entered with the river passing out to the north-west. The route crosses the lako and goes up a nurrow bay for one mile and a lanlf to its head. From hero a portnge of 400 yurds leads to a small lake two miles long, surrounded by steep rocky hills 300 feet high. This lake is left ut its enst end by a half-mile portugo, to another small shullow lake one mile long, surrounded with lower boulder-strewn hills, followed by another portage, a quarter of a mile long, that ends in Square Rock Lake, Squnre Rock soven iniles long, but verv narrow, the avernge breadth being 400 Lake. yirds, with small expansions at both ends and in the middle, where a small brancls of the Big River Hows out on the north side.

The lake is surrounded with lills from 200 to 400 feet high. Tliese, like most of the country from Lake Nichicun, are burnt, and their exposed sicles often appear from $n$ distance to be solid rock, but on close examination they are found to be made up of angular masses and boulder's, closely pucked together. Where the forest remains, it consists almost wholly of small black spruce, with a few larches on the lower ground, and very small white birch on the hillsides. A few Trees. white spruce trees are seen growing on the low sandy terraces about the lake. The route leaves Square Rnck Lake by a small stream flowing in on the south side nenrly one mile from its east end. This stream comes from the eastward, in a wide valley, now filled with modified drift arranged in beds of sand and gravel, which rppears to have once been the bed of a much larger stream than th present. The stream is ascended for four miles, passing on the way twc short portages, where the river falls in shallow rapids from one expansion to another. 
The last portage ends in a lake four miles long and about half a wile wide, strewn with small islands of till, or stratified sand. There is evidence of a terrace twenty feet above the present water-level, and there is a good deal of stratified sand and gravel seen along the shores. High rocky hills rise from either side of the broad valley partly filled by the lake. These hills have been more than three-quarters burnt over recently, and have a very desolate appearance. The trees are somewhat sinaller than those seen about Nichicun, but they still grow up to the summits of the highest hills. A short portage leads to another lake, to the eastiward, a half mile up which another portage is made past a shallow narrows; then the lake widens out and continues eastward for two miles. The hills on both sides are high and are burnt bare; the boulders, having been whitened by the action of the heat, stand out in marked contrast to the blackened vegetation. A portage Eagle Iake. of 400 yards leads to Eagle Lake, on another small branch that flows into the Big River, some distance below. This river is now divided into numerous channels by large rocky islands, which thus form a net-work of lake-expansions over a wide area. Beyond this place the route is very diflicult to follow, passing as it does through chains of lakes filled with islands, with deep bays branching off on both sides. The route in some places leaves the main lakes, passing by shallow narrows into large bays. The dividing up of the river into various channels, that often do not join for several miles, also leads to great confusion. Even with the aid of a map of the route, much time will be lost in following it here, owing to the sameness in appearance of the lalies and bays.

Crossing Eagle Lake, to its east side, one mile, the north channel of Snipe Lake. the branch is ascended one mile to Snipe Lake. Between the lakes the river is rapid and varies from ten to fifty yards in width. The latter lake is two miles and a half long by three-quarters of a mile wide, and runs north ward, with a narrow bay stretching to the east for a nile from its north end. A soutl channel leaves the lake in a bay about one mile above the other outlet. The river again divides, giving two inlets to Snipe Lake with a large hilly island between. The lake is covered with small islands. Many of the surrounding hills are rocky and precipitous, well wooded on the south side, with many blocks and boulders scattered over them. The route follows the narrow bay to the north-east. A portage of three-quarters of a mile leads from it to another lake-expansion of this branch, eleven miles in length,

Long Lake. which is called Long Lake, and lies about N. $60^{\circ} \mathrm{E}$. It is very shallow and full of small islands, while great areas are obstructed with boulders and angulur blocks of rock resting on the flat, shallow bottom. Many 
irregular bays indent the shore, especially on the north side where the land is low. The river flows out at the south-west end, and must be broken by a considerable fall, as the sound of it is heard well up the lake. Several small streams feed the lake, the largest flowing in on the south side. The surrounding hills are rocky and burnt over, and are lower than those about the last lake. They gradually sink towards the east end, where the country is appreciably flatter and lower, with many lakes separated by low ridges.

Two short portages and a narrow lake one mile long, lead to a lake surrounded by low, rocky, boulder-strewn hills, and stretching towards the north-east. The route passes only two miles through the west end of this lake, and up a small irregular bay to the northward. Here a portag of 500 yards ends in a small lake twenty feet above the level of the last. Half a mile beyond, ancther short portage is Watershed made to the last lake on the head-waters of the Big Fiver. The route between the merely crosses this lake, which is large, and stretches away to the north- soak rivers. east, and then passes for 500 yards over a low ridge of boulders, forming the height-of-land between the rivers of Hudson Bay and Ungava Bay. The portage ends in a very large, irregular lake thirty feet below the last.

From the watershed, the route runs northward for six miles, in an irregular course, through Ice-bound Lake. This is another large body of water with wide, deep bays stretching off to the north-east and south-west. The water is very clear and shallow. The cast side is bounded by rocky hills about 200 feet high, while to the westward the land is low, and is probably made up of points and islands in this, or in similar lakes, in that direction.

A small strean flows eastward, from the north side of the lake, Male-otter and the route follows it for six miles to Enchukamao or Male-otter Lake. Lake. The character of this strean is similar to that of others in the region, consisting of small, irregular lake-expansions, connected by short rapids, with portages past three of them. The surrounding country is comparatively low; rocky hills are seen to the eastward 200 or 300 feet high; the rest are much lower, and are composed of till. Where unburnt, the country is covered with small, scattered, black spruce, with white moss coating the ground. Male-otter Lake stretches eastward eight miles, and varies frou two to five miles in width. At its east end it is split into two deep bays by a broad rocky point, that rises about 500 feet above the lake. The summit of this hill is destitute of trees and is covered with white moss. Islands are numerous, and are generally well wooded with small black spruce. 
Character of surrounding colutry.

Lake Kaninpiskau.

Height ahove sea.level.

On the south side bare hills of granite rise often perpendicularly from 300 to 400 feet, while similar hills bound the north side, but appear to be somewhat lower. Both sides have been burnt bare, causing the scattered boulders and blocks that cover the hills to stand out prominently. Along the base of the hills, on the south side, there is a sandy terrace fifteen feet high, marking a former level of the lake. The water is remarkably clear; this is the case with all the water north of the East Main River, and is probably due to the lack of vegetable decomposition in the swainps and small shallow lekes, which to the southward gives the water a dark-brown colour. To the northward decomposition does not take place, at least it is not appreciable, on account of the short summer season during which the heat is insufficient to warm the cold waters fed by streams from the swamps that thaw out only on the surface, to a depth of twelve to eighteen inches.

Male-otter Lake discharges by a short stream from the head of its north-east bay into Lake Kaniapiskau. The route passes up the south.east bay, to its heaci, whence a portage of one hundred yards, over a low ridge, leads to the great lake. The difference of level is ten feet.

\section{Lake Kaniapiskau.}

Lake Kaniapiskau is probably the largest in this part of Labrador. Its greatest length is from north to south, and is said to be considerably greater than that of Lake Nichicun, or above fifty miles. The lake is divided into two parts by a narrows, where the current is said to be strong. The southern part is much the larger. As the route passed only through the northern portion, nothing is known of the lake above the narrows, except from information derived from the guide. A high rocky point stretches out from the east side of the northern part, and along with some islands in continuation of it, practically divides that portion of the lake into two great bays.

From the hill on this point, 300 feet high, a good view is obtained, hut unfortunately the smoky state of the atmosphere obscured it when we were there. From the hill, the south bay is seen extending about ten miles to the base of a conical hill of granite over 500 feet higher than the level of the lake, which is estimated to be 1850 feet above the sea. This hill cuts off the view of the southern portion of the lake. To the westward a deep wide bay stretches towards the south-west to the foot of high hills in that direction. Northward from that bay, a lesser one runs close to Male-otter Lake, where the portage is. The 
lake-shore then sweeps enstward along the point, which extends about five niles in chat direction. The bay on the north side of the point extends to the north-westward about five miles, where the' river from Male-otter lake comes in. Near here the Hudson's Bay Company formerly had an outpost from Nichicun, but it has been abandoned for over twenty-five years. Another deep hay extends to the northward, with a channel flowing out of it, between low rounded hills

The east side of the lake is less irregular in outline, but a wide fringe East shore of of low islands extends from its north end to the narrows, with the Lake Kani river passing out by two channels, one opposite the point, and the other a few miles to the south. The country to the east of the lake is much lower than that on the other side, and consists of low rocky ridges, with wide valleys between, filled with lower ridges of till. The north end of the lake appears to be shallow, and is filled with islands, as is the case with the eastern half of the south bay. The western part of the latter is almost free from islands, and is said to be very deep. The islands about the southern discharges are arranged in parallel lines running north-enst, and are chienly composed of till, with many large boulders. Some are made up of stratified sand, which is also often seen resting on the till. The surronnding country is more than half burnt. The lower unburnt portions and islands are well wooded with small black spruce and a few larch trees. The summits of the high hills along the west side rise above the tree-line.

\section{Koksoak River.}

The largest stream falling into Lake Kaniapiskau flows in at its south Headwaters of end. Its main branch rises in Summit Lake, a body of water situated the Koksoak on the watershed about 100 miles south of the latter. A curious feature is that it has a discharge at each end, the northern one flowing Double dis. into Ungava Bay, while the southern one, is a tributary of the Mani- Summit Lake. cuagan River, that empties into the Gulf of St. Lawrence. This is not an uncommon case with lakes situated along the watershed in the northern region underlain by Laurentiun rocks. The river flowing north from Summit Lake is joined by many other streams, draining the lake-covered region to the south and south-east of Lake Kaniapiskau, so that the river where it flows into that lake, is of large size.

As before stated, Lake Kaniapiskau has three discharges, and the Three outlets route follows the middle and least rapid one. Where it leaves to Lake the lake, the channel varies from 50 to 200 yards in width; it flows 
swiftly, and is soon broken by a succession of heavy, shallow rapids, full of great boulders, the channel being cut in boulder-clay. These rapids are almost continuous for five miles, and no rock is seen in place. The south channel joins the middle one a mile and a half below the lake, and, just above the junction, makes a very heavy rapid. Below the junction, the river is 200 yards wide, and carries about twice as much water as above.

Character of the river bstlow Lake Kaniapiskan.

Character of surrounding country.
Below the rapid, the river, flowing north, widens out into a shallow lake four miles long and about one mile wide, with two deep bays on the west side, into one of which the north channel is supposed to enipty. Northward of the lake there is a range of hills, partly wooded, while in other directions the hills are isolnted and the country covered with low ridges of till. Boulders are still common, but not nearly as obtrusive as in the region west of Kaniapiskau. Leaving this lake the river narrows to a quarter of a mile, and is broken for a mile by a small shallow rapid ; then, narrowing to 100 yards, it flows swiftly for another mile to a second lake-expansion. Here, widening to threequarters of a mile, the river continues northward for two miles in a shallow channel full of sandy shoals and small islands. These islands have a thick growth of stunted trees, not over ten feet high, of black spruce, larch, balsam fir and white birch. A straggling growth of spruce covers the low hills on both sides. Next, turning north-west, the river continues in the sams manner two iniles and then passes into a large lake, full of islands, that extrnds eastward. Where the river turns east, there are two distinct terraces of stratified sand twenty and thirty feet high, with sharp conical hills of boulderclay protruding from the highest. Along the west shore of the lake three miles, a narrows 500 yards wicle is passed, leading into another lake-expansion three miles long and over a mile wide, with a deep bay toward the east. The country here is almost flat, with low hills along the eastern horizon. The river now turns northward again, and for the next three miles flows rapidly in a shallow channel about 400 yards wide, with swampy shores backed with bare hills, less than 200 feet high. Another lake-expansion, one mile across, is followed by a stretch of three miles of river ending in a lake that extends away to the westward. Passing along its east shore, the river flows out one mile beyond its entrance. Now narrowing to 200 yards, it flows rapidly north-east for two miles, then widens to 500 yards for two miles, and, bending to the eastward, flows in that direction for three miles; at two short narrows it is broken into heavy rapids where it passes over low rocky ledges. With the exception of one small huminock, this is the first rock seen below Lake Kaniapiskau, but judging from the scattered 
boulders, the rocks underlying the thick deposits of drift are likely to be Absence of soft inica-schists and mica-gneisses, and this accounts for the change in rock. the character of the country. These soft rocks having been unable to stand the abrading action of glacier ice, have been planed down, and only the harder parts rise in the low isolated ridges seen here. The granites of the region west of Kaniapiskau, being much harder and tougher, resisted the glacial action, and now stand up in the rugged hills previously mentioned.

The river below is split into two main, and a number of smaller channels, with the stream in a shallow channel almost on a level with the surrounding flat country. Our route followed the east channel, which flows north-east fou: miles, and then north four miles, to the head of a heavy rapid. Two large channels join it at the fourth and eightl miles, and there is a heavy rapid between the second and third miles, with a large rocky island dividing it. When again united, the river runs north-north-east for five miles, and flowing on the surface over low, flat' ledges, is almost a continuous rapid for the whole dis. tance. Throughout, the breadth is 400 yards. Three short portages are necessary to pass low chutes.

Turning due east along the southern flank of a low range of hills, the river next narrows to less than 300 yards, and flows swiftly between rising banks of till, with cutcrops of rock along the shore. Now bending east-south-east for three miles and then south for two miles, the stream narrows to less than one hundred yards, and descends in a narrow valley, cut out of till, with a rocky bottom. On the north First gorge of side, the hills increase in lieight as the river descends bèlow the general the Koksoak. level, and at the lower end rise abruptly 500 feet atove the stream. Those on the south side are somewhat lower. In the five miles, the river falls over 150 feet, and is very difficult to pass with canoes. The Indians of Nichicun'hunt only to the head of these rapids, and below there is an interval of over one hundred miles of the river untravelled, as it is utterly impossible to ascend the stream with loaded canoes. Along this portion no portages are cut out past the falls and rapids, and in consequence portage-roads had to be made by us. At the rapid above, the sides of the valley are composed of almost perpendicular walls of till one hundred feet or more in height, resting upon jagged rocks covered with great rounded boulders for thirty feet above the Walls of water-line. These boulders are piled up by the ice passing through packed :1 the gorge in the spring. The till banks at frequent intervals are deeply cut by small tributary brooks. On account of the broken character of the bank above, a portage had to be made along the water's edgo over' the loosely piled boulders and jagged rock. The 
rive: is here so rough, that the outfit had to be carried the entire tive miler, and then the empty canoes were let down along the shore with frequent short portages past heavy pitches. A day and a half of hard work was necessary to accomplish this.

Cliaracter of theriver above the gorge.

From Lake Kaniapiskau to the head of the gorge, the river wanders about almost on the surface of the country, spreading out into lakes, where the surface is flat, and contracting into narrow rapids where it passes between low ridges. It follows the main slope of the country, and falls with the general surface. Where it is obstructed with rapids, these are frequently over boulders without any rock in rlace, especially along the upper parts. The absence of a distinct valley and the presence of rapids over boulder-clny, show that the river is here flowing in a modern course, and does noi follow its pre-glacial valley, which is still filled with glacial débris. At the gorge, this changes, and the river pas 3 down from the general level into a deep distinct river-valley, probably of very ancient origin. This valley, during the glacial period was at least partly filled with till, which in scarped banks and terraces is seen along it, resting on its rocky sides. The river follows this old valley from the gorge to its mouth. The valley is, of course, not of constant depth, but descends in a series of steps, with the gradual slope of the surrounding country.

River below the gorge.

From the foot of the heavy rapid, the river, now in a distinct valley, takes an easy bend to the east and flows in that direction for eight miles. Here the current runs from four to seven miles an hour, with constant small rapids. The river averages 200 yards in width, and descends in a valley from a quarter to a half mile wide, walled in by steep rocky hills that rise 500 to 800 feet above it. These hills are almost wholly burnt, but where unburnt are covered with a straggling growth of black spruce to within 200 feet of their highest summits. The tops are treeless, and are covered with white moss and low arctic shrubs. Boulders are now nearly absent from the sides and tops of the hills, in strong contrast to the hills about Nichicun and Kaniapiskau. Some boulders are seen, but they are so few as not to form a noticeable feature.

The lower parts of the valley are filled with drift, often extending high up the rocky hills in the cuts between them. In the drift the river has cut its narrow channel down to the solid rock below. The rock, where not covered with packed boulders, is seen along the water's edge. In many places the river-banks are formed of tightly-packed, large, round boulders, that line the side to a height of fifty feet above its summer level. These have been transported and packed in their present position by the ice passing down during the spring freshets, 
and their height gives an idea of the volurne and power of the stream during flood time.

Turning south-east, the river continues in that direction under similar conditions for three miles ; then it turns east-north-east, and the ralley and river both broaden. The river, now a quarter of a mile wide, flows in a perfectly straight course for nine miles. Owing to its greater Continuous width, the water is very shallow, and the continuous rapid is full of rapicts. bouldery shoals; the deepest channel being very crooked, requires constant crossing of the streain to follow it. No part of the rapid is rough enough to be dangerous, and the only source of danger is the frequent shoals, on to which the swift current quickly carries a canoe, if a sharp outlook is not kept. The packed boulders still rise fron thirty to sixty feet above the water, with stratified sand and fine gravel, up to seventy feet, where $a$ distinct terrace is seea, marking an older level of the river. Along the margin of th' water there is an almost continuous exposure of solid rock. The hills are less precipitous, especially on the west side. The valley is filled with drift, of which sections are seen along the banks. The river now turns northeast for four miles, and broadens slightly, the rapids giving place to a strong, stendy current of nearly six miles an hour. A mass of ice, twenty-five feet long and six feet thick, was seen at the bend on the north side, piled up on a great quantity of packed boulders, sixty feet abovo the whter, the remains of a great mass shoved there by Ice on banks. the freshet in the spring, and left by the roceding water. But a short time before, it had covered an area of over 100 yards square, but at the time (August 16th), it was melting quickly. Similar masses were seen along that shore for a mile below; they were all about thirty feet above the level of the water, and the largest was 200 feet long by thirty feet wide.

Both shores remain rocky, the rock coming out from beneath the packed boulders. On the west side, near the lower end of the course, there is a well marked terrace, seventy-five feet above the water, that is seen extending downwards for two miles. In places it is tanked by a lower one forty feet high, with the boulders often packed to the top of it. The hills forming the sides of the valley are now aiso.t 500 Valley unch feet high, and this nearly represents the height of the surrcunding lower than country, as all the little streams entering the river do so with falls country. from small cuts slightly lower than the summits of the hills. From the head of the rapids at the gorge, to this place, the river has fillen 420 feet without any direct drop exceeding four feet. The grade is nearly constant, and exceeds ten feet per mile. 
The river next once more bends to the southward, and flows south-east for six miles, with a strong current, in a slightly wider and lower valley. A large brook comes in from the eastward at the fourth mile.

Trees. For the last twenty miles the country on both sides is unburnt, and is covered with scattered black spruce and a few larches, never more than twenty feet high or exceeding nine inches in diameter. The tops of the hills rise from 100 to 200 fect above the tree-lino. Turning again directly east, the river flows in that direction for six miles. The channel along here is wide and shallow, being filled up with sand and fine gravel, borne down by the strong current above and deposited over the flats of this part. Sandy shoais rise slightly above the water in places. The hills on both sides are slightly burnt and are lower, with gentler slopes towards the river than those further up stream. Rockexposures are less numerous, and the ice docs not bank the boulders on the shores to more than fifteen or twenty feet high.

After a bend to the east.south-east, a small rapid is passed, and three miles below a little river falls in on the south side. This is the first tributary of any considerable size that joins the main strenm below the commencement of the river-valley proper, and there must be only a narrow strip on either side draining into the river, the rest of the

Parallel valleys. country probably being cut up into parallel valleys, with watercour'ses in each, which only join the main stream at long intervals. The small branch comes in with heavy falls, along the side of $\leadsto$ rocky hill of 800 feet. Below, the river again flows eastward for three iniles, with a strong current, and has a terrace of thirty feet ${ }^{\prime} w$ the south side. A bend of a mile and a half to the north-east is followed by another long stretch to the eastward. A heavy rapid, four miles long, begins at the upper part of the north-east course. Then the channel broadens somewhat, and the current is considerably slacker for the next eight miles. The valley here slopes.gently upward, on both sides, and is partly filled with drift. The hills are high, those on the south side rising from 600 to 800 fect, with well marked terraces at sixty and thirty feet, cut out of the drift along their flanks. The north side is unburnt, and the trees are all small, stunted black spruce, that grow to within 200 feet of the summits.

The general course for the next ten miles is east-north-east, and, the valley narrowing, the river for the first six miles is a succession of heavy shallow rapids, full of boulders. Along the flanks of the hills on the south side, several distinct high-level terraces are seen at 30 , $60,75,100$ and 150 feet above the present river-level. The upper unes are broken, and only the lowest two are continuous. Below the rapids the river widens to more than half a mile, and is correspondingly 
shallow, with a sandy bottom. The hills on both sides now grndually lower, and those on the south side retreat, leaving a wide, low, driftcovered valley between their base and the river. A bend of two miles to the south is followed by a stretoh towards the east five miles long. At the foot of the first bend there is a rapid of three-quarters of a mile where the river is over half a mile wide, and is in consequence very sliallow. Below this rapid the river is nearly a mile wide, and flows with a strong current until it reiches the base of a low range on the north side, where it narrows to 400 yards and is broken into heavy rapids. The river now appears to break through this low range 200 to 400 feet high, and in doing so bends sharply to the south-oast for two miles, then north-east two miles, again south-enst two miles, and finally south for three miles, passing out into a broad valley, where it is joined by the Katakawamastuk or Sandy River, a large Sandy River. branch from the eastward. While passing through the hills, the river forms a continuous strong rapid, culminating in a twenty foot chute a short distance above the forks. Although the riverdescends rapidly, it does not fall af quickly as the general level of the country here, and, in consequence, below the forks it flows nearly on the general level, with only low rounded hills seldom more than 100 feet above its shallow valley.

In this manner it Hows enstward for five miles, with only one small rapid, to the head of a rocky gorge. From the head of Second gorge. this gorge $a$ very distinct drop is seen in the country to the enstward, with high hills that appear to be on the level with the land about the gorge bounding the horizon. At the head of the gorge the river is split up by little rocky islands into a great number of small channels, and it passes through them in a succession of small chutes or heavy rapids, gradually collecting into one channel; after half a mile, the strean, a mass of foam, rushes down $n$ narrow gorge from thirty to one hundred feet wide, with perpendicular rocky walls from 50 to 100 feet high. In one mile the river falls 110 feet without any direct drop of more than five feet. The portage passes over the bare rock on the south side. Below the gorge, the channel widens to half a mile, and continues eastward, with strong current and flat rapids for three miles. Here again narrowing to 100 feet, it falls thirty feet into a narrow rocky gorge, which was named Eaton Cañın, and tura- Eaton Cañon. ing directly south, rushes down between jagged perpendicular walls with a width varying from tifty to one hundred and fifty feet. As the stream descends, the banks rise and become 200 feet high a quarter of a mile below the first fall. Here the river turns sharply to the northeast and continues as a rushing torrent, through a deeper and still 
narrower gorge, with overhnnging walls of red granite on the east side. The overhang is so grent, that a stone dropped from the top on this side would almost reuch the foot of the opposite cliff when it struck the water 350 feet below. After falling in this manner for a third of a mile, the river widens to a hundred yards, und changing its direotion to east, descends less nbruptly for a quarter of a mile, while the walls of the canon are a hundred feet lower, and much less nbrupt. Next, turning north, it makes a direct full of a hundred feet into a circulır basin about fifty yards in diameter. Nothing but scething water and foun is seen in this rocky basin, whieh resembles a gigantic boiling cauldron. A small brook, on the north side, also falls into the basin, descending the perpendicular wall in a cascule 200 feet in height. The river leaves the basin by a nurrow rocky chnnnel, rushing out with a fall of thirty feet in immense wnves that gradually subsirle in a second and larger circular basin at its foot, where it widens to 150 yards. On each side of the centrul current there are strong eddies rushing up to join the dowu stream, where it passes out from the busin above; and, wh. "o the conflicting currents meet, great whirlpools are periedically formec. A small rocky island divides the river into two nurrow channels where it leaves the larger basin, whence it flows north-east for two miks, and then gradually bending south in the next mile and a half, still a nundred yards wirle, it rushes along in heavy deep rapids, between vertical walls of granite capped with drift that rise

fioodwood River. from 100 to 300 feet above its surface, until it suddenly bursts out into a wider valley running norih-north-east, with a large branch called Goodwood River flowing down it from the soutliward.

Portage past Eaton Cainon.

The portage past the cañon was made along the east side, leaving the river above the first fall, coming out on the top of the bank at the sharp hend to the nortli-enstward, and thence striking due east for a mile over low rocky hummocks, with swamp between, and descending the steep rucky course of a small stream to a narrow valley 200 feet below. It then follows this valley for half a mile to a small lake, after crossing which a portage of 150 yards leads out through a narrow gorge, with perpendicular walls 160 feet high. Large masses of rock have fallen from above and huve filled the valley completely to a depth of seventyfive feet. The small river passes under this mass of broken rock, and in so doirg falls twenty-five feet, to where it enters the main stream on the south side of the larger basin at the foot of the cañon. Over this mass of broken rock canoes and outfit were carried, as there was no other place where the main valley could be entered, and the difficulty of the undertaking may be imagined when it is stated that over half a day's labour was required to pass these 150 yards of broken rock. 
In the small valley, the trees are mueh larger than any seen since leaving Lake Mlistussini. Growing on a rich alluvial soil along the banks of the brook, is white spruce eighteen inches in dianeter at the ground and sufliciently long to muke two twelve-foot logs. The trees Large trees. are, however, very knotty. Larch of similar size is also seen here, along with white birch eight inches in clinneter. The first white spruce on the bauks of the river was found on a low bank of sancl and gravol at the mouth of the Suncly liver. Below that point, small trees of this species are commonly found growing on the lower terraces of stratified drift. The higher lands support only a small growth of black spruce and a few larches.

Below the junction of the Goodwood River, the main strean runs River below north-north-east for six miles, with a rapid current, in a channel 300 ficodwood yarcls wide. On the west side there are scarped banks of stratified drift one hundred feet high; and rocky shores on the east side are capped with drift and have two well-defined terraces at 60 and 100 fect above the river, the lower terrace being cut in fine sand and grown over with fair-sized white and black spruce. Four or five miles beyond the lower end of this course there is on the east side a range of bare rocky hills over 1000 feet high. Widening out to nearly half a mile, the river then turns north, and for fifteen miles flows with $n$ moderate current in a shallow channel filled with sandy shoals. The eastern lounk is very rocky, and from 200 to 300 feet high, with patches of sand along the gulleys where the brooks tumble in. These rocky banks form the fooc-hills of the barren range before mentioned. The west side has also high and in many places rocky banks, lut the country behind is much lower than on the other side, with a few isolated hills more than 500 feet high. On this side the surface is mostly unburnt, with fnir-sized black and white spruce and larch growing on the stratified sands of the terraces, but with only a scant, straggling growth of black spruce on the rocky and drift-covered hills above.

Remains of terraces are seen along both sides at 10,60 and 75 feet, Granite Fall. that at 60 feet being the most constant. Contracting now to less than one hundred yards in width; the river falls eighty feet over a ledge of rock at the Granite Fal!. Two small rocky islands divide the stream into three channels, the largest being on the north side. There is a first chute of twenty feet followed by a perpendicular, fall of sixty feet in the smaller channels. In the main channe', a largo mass of rock broken awny, is apparently lodged at the foot of the fall, as the water dashes up from below in a great wave forty feet bigh. The river falls into a beautiful, circular basin, nearly half a mile in diameter, formed by a deep semi-circular bay on either side. These 
bays are surrounded by woll wooded, perpendieular cliffs 200 feet high. A wide bench of sunali, well rounded beulders, rises shurply from the water and stretches for sixty feet to the foot of the perpendicular walls.

[Derp channe] Below the falls the river again passes into n deep valley lesy than $n$ cut in irift. mile wide, with rocky walls that often rise sheer from 800 to 1000 feet. This valey during the glacial periorl has been partly filled with drift and the river has since eut inte it a narrow ehannel, with high scarped barks of from 100 to 300 feet, with terraces from 50 to 150 feet above the present level. The direction of the valley is nenrly nortl.west, ind the river, nbout 30 y yards wide, rushes down it in a zigzag. At every bend the strenm sirikes ngainst the rocky walls, while a low bar of large, round water-worn bouklers extends out from the opposite shore, throwing the waters with force ngninst the rocky banks, and forming deep wild rapids at these points. In this munner the river continues falling rnpidly for ten tniles; then the valley grndually widens and there is n considerable interval of drift-covered land between the river and the rocky hills on the east side, where terrnces at 20,50 and 100 feet are seen, cut in the drift. The west side is still bounded by rocky hills, that rise alout 400 feet. In the valleys of smull strenus cut into the drift, and on the terrnees, white spruce trees forty feet high and eighteen inehes in diameter are not uncommon.

This valley continues from three to five miles wide for twenty-five miles nnd is remarknbly straight, the course being about north-west. The river skirts its west side, where it flows close to the base of the rocky walls, that rise from 200 to 400 feet nbove it. For seven miles it does not avernge over $\mathbf{4 0 0}$ yards in width, is very shallow and greatly obstructed by sand and shingle bars, over which it breaks into rapids. At the end of this stretch, $a$ small river comes in from the west, through $a$ deep narrow cut in the mountains. Terraces are continuous along the east side at heights varying from 20 to 150 feet Balsam above the river. Balsum poplar trees forty feet high and ten inches poplar. in diameter were seen on the lower terraces, along with white spruce trees sixty feet high and over eighteen inches in diameter.

Below this branch, the river soon widens out to more than a mile, and is broken by sand bars into a number of wide shallow channels. The bottom is formed of shifting sands. The banks are lower and are composed of stratifierl sand cut into terraces. The current is slacker, and at the end of fourteen miles another and larger branch, Death River. called the Tipa or Death River, comes in from the west, joining the main stream by three channels, as it falls over a low ledge of gneiss. Below this tributary the river narrows somewhat, but still 
remains shallow, with lower banks, for four miles; then, narrowing to less thun 400 yards, it bends to the northward into the hend of Cambrian Iake, which is nbout two miles wide and surrounded by high rugged hills of Cambrinn rock.

In fourteen miles, the luke gradually sweeps round from north to Cambinian north-west, and at the end of the curve, another small branch from the weat flows in from a wide vulley between lugh burren hills that rise from 800 to 1200 feet above the whter.

The physicnl aspect of the country chnnges as soon as the Cumbrian Character of aren is entered. Where the underlying rock is Laurentian gneiss or the cuuntry. granite, the hills, though often high and with perpendicular sides towarils the river-valley, always have rounded tops, with long gently curved outlines, while the hills formed from the stratified Cambrian rocks, wro much sharper and more rugged.

The general dip of the rocks is towards the nortl-east, and, in consequence, the mountains which they form show steep elill faces towarcls the west, with long gentle slopes on the opposite side. These hills run in ridges roughly parallel to one another and to the general strike of the rocks, that is, from south-enst to north-west. They rise from 800 to $\mathbf{1 5 0 0}$ feet above the surface of the lake, which is nbout 400 feet above sea-level, and on the western side often have perpendicular clifts over 500 feet high, with n great talus of broken rock at the bottom. The cliff-faces have generally a reddish colour, due to the oxide of iron present in all the rocks of this series. All except the lower slopes of these hills are barren, or covered only with arctic shrubs and mosses, with patches of snow in gullies near their summit; this adds greatly to the grand and desolate scenery, while the beauty of the pleasant, wooded valley of the river is enhanced by the contrast.

From the entrance of the small branch, the valley again turns northward, and continues in that direction for eleven miles, to where the lake gradually changes into the river again, with high hills on the east side, in which the Cambrinn rocks are seen resting on rounded masses of gneiss. The hills on the west side retreat, leaving a wide sandy plain, through which a large branch called the Piachikinstook or Ice-dam River flows, entering the naain strenm Ice-dam with in henvy rapid two miles above the end of the course. The River. main stream gradually narrows, and becomes shallow along the lower part of this strutch, where it runs betwcen low banks of sand. Turning next to the north-east for seven miles in a wide sandy valley, it flows along with increased eurrent in a shallow channel three-quarters of a mile wide, until it re ches a barrier of black shale and limestone, 
Shale Falls.

Swampy-bay River.

Character of river below Swampy-bay River. where it falls sixty feet in about 200 yards, at the Shale Falls. Below the falls, there is a circular basin with steep sandy banks sixty feet high, and from it the river passes out to the north, and flows in that direction for two miles between te:raced banks sixty feet high covered with large spruce, with outcrops of iron ore showing beneath the sand along the water's edge.

Gradually bending around to the north-west, the river flows in that direction for twenty miles, until it is joined by a large branch from the eastward called the Swampy-bay River. By this stream, the Indians formerly travelled to Fort Nascaupee, which was situated on Lake Petitsikapau on the upper waters of the west branch of the Hamilton River, and only a few miles from the watershed separating it from the Swampy-bay River. Along the first five miles of this course, the river is about half a mile wide, and flows between sharp rocky hills, which rise 600 to 800 feet above it. Here an almost continuous exposure of bedded iron ores is seen, consisting of red and specular hematite, magnetite and sidertie, interbedded with siliceous limestones and jasper. After five miles, the hills retreat on both sides, leaving a wide valley of drift, through which the river runs with a steady current in a shallow channol half a mile wide. The drift is cut into terraces at $30,50,100,150$ and 300 feet. A small branch from the east flows in here.

After four miles the hills again approach the river on the west side, where they are sharp and rugged and rise from 600 to 800 feet in precipices often terminated in sharp peaks. Two miles above the forks there is a strong rapid half a mile long, where the river narrows to less than 200 yards. The sands in the valley are greatly drifted by the winds, and in one place the drifts are covering up trees twenty feet high. The country is nearly all burnt from the falls to the mouth of the Swampy-bay River.

For eight miles below the Swampy-bay, the main stream flows northwest in a narrow valley, between sharp rocky hills, from 400 to 600 feet high. The river-channel is from 200 to 600 yards wide, and the current is strong. The lower parts of the rocky hills on the east side, are covered with sandy drift and are terraced at several levels up to 200 feet above the present height of the river. The hills on the west side rise directly from the water and have very little drifti on their flanks.

The river next turns north-north-west for seven iniles, and then north for seven miles more. Along the upper of these courses the valley widens to over two miles, and is filled with drift, terraced to the 200 feet leve!, behind which it slopes gently upwards with a few sharp 
rocky hills projecting above it. Along the second course the land on the east side is only about fifty feet high, for three or four miles to the base of the hills. The country on the west side is higher and the hills come out at intervals along the river, with a large brook flowing in from the west, about two miles from the upper end of the course. The river here widens out to nearly a mile, and its current is not strong.

Along the last mile, the river narrow3 to 400 yards and flows swiftly between hills of limestone from 200 to 600 feet high, very sharp and irregular in outline. The rock has the appearance of being greatly faulted. Turning now sharply to the north-east, the river continues to flow swiftly in a narrow, rock-bound channel for three miles, where it again turns northward, and continues in that direction ten miles to the Pyrites Chute where it falls thirty feet in a half PyritesChute mile over black shales on edge. Along the upper half of this course, the limestones are almost continuously exposed along the river-banks, rising in sharp ridges on both sides from 100 to 800 feet high. Along thie lower half, the hills retreat and leave a wide sandy valley, covered with black and white spruce with a few larch and white birch. The largest trees rarely exceed twelve inches in diameter and are much shorter than those seen about the Cambrian Lake.

Below the chute, the course is north-west for fifteen miles. For four miles the channel averages three-quarters of a mile in width, and the surrounding country is low and flat, with sharp hills of rusty rock and a few exposures of limestone on the east side. A number of low islands of limestone occur in the next mile, at the end of which the river, at the Limestone Falls, descends sixty feet over ledges of that Limestone rock, which cross the river-valley obliquely, and form a dam over which Falls. the water pours in three main channels. The middle channel follows the strike of the rock and forms a cliute, while the other two fall vertically, directly across the strike. Below the falls, for four miles, the river, about a half mile wide, flows hetween scarped banks of sand and gravel seventy-five feet high; and then, narrowing to less than 200 yards, for five miles it ruslies through a narrow valley called Manitou Gorge, cut out of limestone and shales, with walls from 50 to Manitou 300 feet high. Heavy rapids are met with throughout the gorge, and Gorge. considerable danger was encountere 1 running these with half loaded canoes, especially at the lower end, where outcrops of limestone cross the valley, hemming the water iuto narrow channels and causing small chutes. Below the gorge, the river for six miles gradually bends towards the east until it is joined by the Natwakani, Larch or Stillwater River, a large branch from the west. Along this portion the current is strong, and a number of large islands of sand and shingle 
divide the river into several channels. The banks are cut out of clay, overlain by sand, and often over one hundred feet high. As the forks are approached, the banks on the west side become lower, and form a

Stillwater River.

Route to Hudson Bay.

Character of river and country below the Stillwater.

between low, terraced bauks in a valley two or three miles wide, bounded by sharp hills from 500 to 600 feet high. These hills, still composed of Cambrian rocks, run in sharp ridges from a quarter of a mile to two miles apart. The direction of the ridges is roughly at right-angles to that of the river. They resemble one another very closely, and sixteen of them were noted in as many miles. They have a cliff face towards the south-west, and a gentle slope towards the north-east, apparently coinciding with the dip of the rocks. All the cliffs show a thick capping of hard rock, probably trap, with rusty weathering shales beneath. On the steep side, the hard capping rock often projects beyond the softer shales, and so forms overhanging cliffs. The lower valley, where unburnt, is wooded with small black and white spruce and larch, growing in open glades upon

Trees. the terrace. These trees also grow on the hillsides, up to about 200 feet above the river. Above this, only mosses and arctic shrubs are seen about the watercourses, the remainder being naked rock, which forms over one half of the area under consideration. Ten miles below the Stillwater, a small river comes in from the westward. The valley, five miles below the forks, widens to five or six miles, and the river spreads out to over a mile, becomes very shallow, and is greatly obstructed by sand and shingle shoals, as it flows along with a strong current, in the same direction for twenty-one miles.

Toward the lower end of this reach, the sharp Cambrian lills give place to others of Laurentian rock, whose outline is less rugged and more rounded. The interval between the river and the rocky hills is 
occupied by a terraced sandy plain from twenty to fifty feet above the river and is partly covered with small trees.

Low ledges of gneiss now cross the stream and form a number of small rocky islands, causing a heavy rapid for nearly a mile, followed, two miles below, by another a quarter of a mile long. At both rapids, the water is shallow, and the channel is obstructed by reefs and large boulders. The foot of the second rapid marks the head of tide-water. Head of tide-

Froin here the course changes to east-north-east for eighteen miles. The hills on both sides retreat still farther, and appear to be considerably lower. The river is now frem two to five miles wide, and is broken into numerous channels by long low islands of sand, and shoals bare at low water. The river banks are from ten to twenty feet ligh, with a wide drift plain extending to the foot of the bare, rocky hills, on which the remnants of terraces are seen up to 300 feet above the present water-level. This plain is only partly wooded with small black and white spruce, and but two clumps of small balsam poplar were seen on the north bank. Turning again to the north-east, the river becomes still wider, with a deep bay on the north side, around which the rocky hills sweep; these then cross the river seven miles down the course, where they form a number of high rocky islands, that hem the water into deep channels, through which it rushes rapidly in and out according to the state of the tide. At and below the islands, the river varies from a mile to a mile and a half in width, and its valley is bounded by rounded rocky hills, rising from 100 to 300 feet directly from the water, with only in a few places a narrow border of drift between, which is sometimes terraced one hundred feet above the present sealevel. The course continues nearly north-east to the mouth of the river, some.twenty miles below.

Fort Chimo, the Hudson's Bay Company's establishment, is situated For shimo. facing a small cove on a low terrace on the south shore, about two miles below the islasds. The terrace is about 200 yards wide, and is backed by low rounded hills of gneiss. Small black spruce trees grow only in protected hollows about the post, and the general aspect is very uninviting, with barren, rocky hills bounding the horizon on every side. The post consists of about a dozen buildings, including a dwelling house for the officer in charge, four or five for the servants, a trading shop, office, two provision stores, oil shed, salt shed, carpenter, cooper and hlacksmith shops and a dwelling house for the Indians. These buildings are all, or nearly all, made of imported lumber. There are a number of small boats attached to the post, along with a small sloop and a steam launch, used in connection with the salmon fishery. At present a vessel of about twenty tons is being built there, 
from wood obtained about Ungava Bay ; most of it coming from some distance up the Whale River, which is the next large strenm flowing into the bay to the eastward. Firewood for the post is cut during the winter in the vicinity of the first rapid, and is rafted down the river in summer.

The post is supplied by the company's steamer "Eric," which arrives at Fort Chimo about the first week in September, and remains there, loading and unloading, for about two weeks. This is the only conmunication with the outside world, and when the ship leaves, all touch with civilization is lost until the following year.

Fur trade.

The fur tracle is, of course, the most important, and is carried on both with the Indians and Eskimo. Foxes are the most numerous of the fur-bearing animals, and are found throughout the barren and wooded country; they occur as to numbers in the following order : white, red, cross, black and blue. Martens conie next; and are chiefly taken by the Indians along the edge of the wooded country, about the head-waters of the rivers. Their fur is very thick, dark and long, and the skins are generally larger than those caught farther south. Wolverines are common along the edge of the barrens and nortliward. White bears are killed frequently along the coast. Black bears are very rare, and specimens of the barren-ground brown bear are obtained only at infrequent intervals. Mink and otter are not common, and the beaver is not found north of the thickly wooded area. Fornierly a great number of dressed caribou skins were traded at Ungava ; but during the last two years very few were brought in, owing to a change in the routes of migration of that animal.

Salnion fishery.

The salmon fishery is carried on at a number of places along the river, below the post, during the month of August, and the annual catch averages one hundred tierces for export. Salinon are also taken in the mouths of the Whale and George rivers, the average catch at the former place being fifty tierces, and at the latter one hundred and twenty tierces. Formerly the company employed a small refrigerator steamer in this trade at Ungava, and the frozen salmon were taken to London for sale. This has been abandoned for several years, and the salmon are now split and salted. The white porpoise is also taken at Ungava, on the Leaf River, a stream a short distance north of the mouth of the Koksonk, and at George River. The total amount of oil so obtained is about eighty tierces of forty gallons each. Other articles purchased are feathers, ivory and eider down.

Seven years ago there were ninety families of Indians trading at Fort Chimo. But in the famine, due to the failure of the caribou 
hunt, during the winter of 1892-93, nineteen families starved to Indians. death in a body, and at another place six fanilies were totally lost; besides these, all the other Irdians were throughout the winter in a state of chronic starvation, sand many died, so that out of a population of two hundred and fifty persons, less than one hundred and fifty survive.

\section{IIamilton Inlet.}

Hamiiton Inlet, Invuktoke, or Esquimaux Bay is the lnwigest and Hamilton most important of the many long, narrow fiords or inlets $1 \%$ indent Inlet. the Atlantic coast of Labrador and Newfoundland. Its greatest length, from Indian Harbour to the mouth of the Hamilton River at its head, is slightly over one hundred and fifty miles, while its average breadth is about fourteen miles. The longest axis lies northeast and south-west. At its mouth, from the mainland near Purple Island, on the north shore, to Grinder Point, on the south side, the distance is twenty-three miles. Thence the inlet gradually narrows for forty-three miles to the mouth of the Double Mer, where the width is less than two miles. Here the inlet is divided by a long rocky ridge, the northern portion, or the Double Mer, extending Double Mer. westward some forty miles. A narrow, less than one inile wide, extends from the point five miles into the main, or Groswater Bay. Again widening, the channel is divided by a large rocky island five niiles long called Henrietta Island. At its head, on the south side, a long narrow bay, called Back Bay or Backway, runs off to the Backway. eastward for about twenty-five miles, with an average breadth of four miles. At the east end of this bay a ridge one hundred and fitty feet high separates it from a small lake, with a sluggish brook that empties into a bay on the coast. The total distance between the head of the bay and the sea coast is not over ten miles; the country between appears to be wholly formed of drift material, and it is quite probable that in pre-glacial time there was an opening of the coast here.

The main bay above Henrietta Island quickly expands to four miles, and then more gradually to twelve miles, at the mouth of Valley Bight, eighteen miles above the narrows. Valley Bight is a Valley Bight. small bay on the north side, about three miles wide at its mouth, and gracially narrowing for five miles to its head. From the mouth of this bay the main body has an average breadth of eight iniles as far as Charley Point, some eight miles up. This portion is grently obstructed by islands, of which Neveisik, St. John and Haines islands are of large size, and are also high and rocky. From Charley Point 
to Mulligan Point the distance is thirty miles, and the average breadth of this portion is fifteen miles, with two large bays, one on each sicle. That on the north side is called Nebavick or Mulligan Mulligan Bay. Bay, and extends behind the long, low point of the same name. It is about four miles wide at its mouth, and of about the same depth, with a small river coming in at its head. The bay on the south side is called Etagavlett or Big Bay; it is ten miles wide and nearly five miles deep.

From Mulligan Point to the mouth of the Northwest River, some twenty-three miles, the breadth gradually decreases to eight miles, and considerable intervals of low sandy land intervene between the water and highlands behind, while the waters on both sides are shallow, and are greatly obstructed by sandy shoals and low islands, especially on the north side, where a fringe of islands extends several miles out from Mulligan Point to within four miles of the mouth of the river.

Northwest River.

Kenamou River.
The Northwest River flows in at the foot of a small shallow bay, and at. its mouth is about 100 yards wide, with an average depth of fifteen feet. The narrows are only half a mile long, and then the river ex pands into a shallow lake, one mile wide and three miles long, at the head of which is another contraction of about 400 yards, with a strong current where the river flows out of Grand Lake. This is a large body of fresh-water extending westward some forty miles, and is from two to five miles wide, and very deep. As only a comparatively narrow strip of low sandy land separates this lake from the bay, and the sand has probably been deposited there by aqueous or glacial agencies, it is prolable that at no very remote time the lake formed an extension oî the present inlet.

On the south side, immediately opposite the mouth of the Northwest River, is Carter Basin. This is about three miles long and a mile and a half wide, and is connected with the main body by a channel little over one mile long. Into this basin two rivers empty, the larger or western one is called the Kenamou River. It is a large stream that rises on the highlands to the south-west, where its sources interlock with those of the St. Augustine and Natashquan rivers, which empty southward into the Gulf of St. Lawrence. The Indians report that it flows through a deep valley in the Mealy Mountains and is unnavigable with canoes, owing to the almost continuous, steep, shallow rapids. No high falls are reported on this stream. The smaller stream is called the Kenemich River, and takes its rise on the top of the Mealy Mountains only a short distance inland, to the south and south-east of its mouth. It descends the steep sides of the hills close to its mouth in a succession of high and beautiful waterfalls. 
From the mouth of the Northwest River, the shore trends southward nine miles to the end of Sandy Point, a low, broad expanse of Sandy Point. sand stretching this distance out from the north side, evidently the remains of drift brought down by the Hamilton River. Opposite Sandy Point the bay is only three miles and $a$ half wide, and shoal water, caused by an extension of the point, continues to the south side, with only eighteen feet of water at the deepest part, where the channel is less than a half-mile wide.

Beyond the point, the shore again trends northward, forming Goose Goose Bay. Bay, which averages nine miles in width and is nearly twenty miles long, to the head of Terrington Basin, where Goose Bay River flows in. This is a shallow stream, draining a considerable area of country between the Grand and Northwest rivers. Goose Bay is in most places quite shallow, being filled up with sand brought down by the Grand or Hamilton River, which flows in on the soutl side, nine miles above Sandy Point. A low sandy point, about five miles wide, separates the river from the upper part of Goose Bay.

The country surrounding Hamilton Inlet is generally higlt and rocky. Character of On the north side, commencing at the entrance to the bay, the hills surrotinding range from 100 to 400 feet, and are only partly wooded with sminll black spruce, in the valleys and on the protected sides. As the narrows are approached, the land rises from 200 to 500 feet, and continues between these heights, until Valleys Bight is passed. Beyond, it is still higher, seldom under 500 and often over 800 feet, forming a high rocky ridge separating Double Mer from the main bay. Fifteen miles above Charley Point, the hills pass inland around the head of Mulligan Bay, leaving a wide interval of low land between their bases and the shore.

Still continuing inland, the hills cross from the head of Mulligan Bay to the shores of Grand Lake, and are more irregular in height and outline than below. One hill called Mokami, or Kokkak, rises in an Moknmi Hill. imposing cone of over 1000 feet, with bare rocky sides and top, forming a conspicuous landmark, said to be visible from any high hill, within a radius of seventy-five niles. The hills nbove Northwest River skirt the north side of Goose Bay, and gradually close in beyond it, to form, with those of the south shore, the wide valley of the Hamilton River.

The country along the south side of Hamilton Inlet at its entrance, is comparatively low and swampy. The hills first reach the shore about fifteen uniles below the narrows, and then follow it closely to the mouth of Backway. Along the narrows they rise abruptly from 500 
to 1000 feet, and in places are flanked with sandy teiraces up to 150 fect above the soa. Along Backway they averuge 600 feet, and Monat. culminate in a rounded conical peak cnlled Monnt, over 1000 feet high.

On the other side of Backway there is generally nu interval of low land, rising in terraces to the foot.hills of a high, barren range called

Mealy Mountains. the Mealy Mountain, that occupies a large area of country between the south side of Hamilton Inlet and the head of Sandwich Bay. These mountains rise precipitously froun 800 to 1200 feet along the side of the inlet, without any low land, from the mouth of Backwny to within ten miles of the mouth of Carter Busin, where they pass inland, and ultimately form the south wall of the Hamilton River val. ley. Along the inlet the sides and tops of these hills are alnost totally devoid of trees, owing to the blasts of the prevailing cold north-west wind that sweep across the bay, especially during the winter season. Inland, it is reported that small trees grow abundantly in protected valleys. As the head of the inlet is approached, the trees ars seen to cover the lower slopes and to rise higher and higher, until near the mouth of the Hamilton River, they are found extending to the very tops of the hills, here from 600 to 800 feet high.

George Island. Below the narrows, the inlet is obstructed by a number of large rocky islands; of these the most conspicuous is George Island, which lies about six miles off the south shore, at the entrance. It is nearly four miles long and in its highest point 750 feet above sea-level. A number of stnaller islands are clustered along the shore, on the north side nt the entrance, and Indian Harbour, an important cod fishing station, is situated among these. From the entrance the inlet is practically free of islands to within half way to the narrows, where it becomes obstructed by several large ones scattered up its middle. The islands above the narrows have been referred to previously as extending as far as Charley Point.

Depth of water.
Below the nurrows, the greatest depth laid down on the chart is fifty fathoms, and the average depth is about thirty fathoms. The channel at the narrows and on the north side of Henrietta Island, ranges from ten to twenty fathoms in depth. Above, the water rapidly deepens, and soon shows ninety-two fathoms; it continues very deep to beyond Mulligan Bay, where it begin to shoal, especially along the shore, a fact probably due to the filling up of the bottom with material brought down by the large rivers emptying into the head of the bay. Twenty fathoms appear to be the average depth of the deeper parts to nearly opposite Northwest River, then it rapidly shoals to fifteen and to five fathoms, until the bar at Sandy Point is crossed, after which slightly 
deeper water is found, which again shoals gradually to three fathoms at the mouth of the Hamilton River.

At Indian Harbour the tide rises seven feet at springs; at the Rise of tide. lower end of the narrows the rise is four feet, while above the narrows the rise is only about two feet and continues the same to the head of the inlet, where the rise and fall of the tide is much modified by the direction and strength of the wind. Below the narrows, there is a strong current formed by the ebb and flow of the tide; while through the narrows the rising and falling water rushes with a velocity varying from four to seven miles an hour, and in a number of places henvy rapids occur, which, with whirlpools and eddies, render the passage of small boats dangerous when the current is at its strongest. Above the narrows, there is no perceptible current, except that caused by winds. The shores of the outer part of the inlet are partly wooded with small black spruce and larch, while the hills and islands support only $n$ growth of low arctic shrubs and willows. As the narrows are approached, the trees lecome larger and on the protected north side cover the hills to their tops. Whito spruce, balsam fir and small Trees. white birch are seen. Continuing up the bay, the trees become larger and better until on the low lands about its head, plenty of trees of the above species grow to sizes that fit thetn for commercial purposes, and aspen and balsam poplar are abundant. At Northwest River, and also at the mouths of the Kenamou and Hamilton rivers, good crops of potatoes and other garlen vegetables are grown annually, Crops. and it is said that onts will readily ripen also. At and below the narrows, the cold arctic current, which passes down the const, so lowers the general summer temperature, that potatoes cannot be profitably grown, and garden crops are confined to turnips, radishes and lettuce.

Hamilton Inlet is the present southern limit of the Eskimo on the Eskimo. Atlantic coast. There is now a little tribe of some half dozen families living in $\log$ houses on the shore of a cove called Carawalla at the lead of Henrietta Island. A few more families are scattered along the shores of the lower half of the inlet. They are in a state of semicivilization, having adopted Europenn dress, and all talk more or less English. They are poor and dependent on the fishery and seal hunt for a livelihood. The Hudson's Bay Company have two establish- Hudson's Bay ments on Hamilton Tulet; the larger, called Rigolet, is situated on the Conpany north shore at the narrows, about three miles above the entrance to Double Mer. This is the head-quarters of the Labrador Coast, or Esquimaux Bay district, the officer in charge having under his care the posts of Cartwright on Sandwich Bay, of Northwest River at the nouth of that stream, as well as those of Davis Inlet, and of Nachvak, both situated on the coast to the northward. 
Trade. The post at Rigolet consists of nbout $\mathrm{a}$ dozen houses ard stores, and trade for fur and fish is curried on with the Eskimo and "plunters." The trade of the post at Northwest River is made witl the "planters" living about the upper part of the inlet, and with the Indinus, who liunt in the country drained by the Hamilton and Northwest rivers, as well as with those hunting to the soutliward in the Menly Mountnins. A Roman Catholic chapel was erected some years ugo nenr this post, Missionurie.. and a missionary priest from the St. Lawrence used annually to visit the Indians there, during the summer. Theso visits, it is understood, are no longer to be made, the Indians being advised to go instead to Mingan, or other posts on the St. Iawrence, to meet the missionaries. All the Indians of the region profess Christianity, and are very cureful to keep all the observances of the churgh, even when far inland, but their beliefs seem to be inextricably mixed up with their older pugan ideas, and often their views on subjects of religion are very curious.

Indians. The Indians frequenting Northwest River post ure probubly the unost miserable and ill-conditioned in Labrador. Being decr hunters, and consequently depending largely on the caribou, both for fcudd and cluthing, they have little inclination to trap fur-bearing aninals and thus improve their condition by trade. As their wants are inuinly confined to tea, tobacco, powder and shot, and some few articles of elothing, a small amount of hunting only is necessary to provide their price, and beyond this, except for the lnbour of following the deer, or tishing, they do nothing, spending uuch of their time lounging about their tents. They will not work, even when offered very high pay, and when asked so to do, simply laugh nud say they are not hungry. They are so improvident that they never lay in a stock of fish in the nutumn, as the Indians to the westwurd do, and when during the winter, from some cause or other, they fail to find the caribou, they are soon reduced to starvation, and many die.

These Indians belong in part to both the Montagnais and Nascaupee tribes. The former tribe hunts between Hamilton Inlet and the Gulf of St. Lawrence, the latter to the west and north-west of Hamilton Inlet. No great physical difference can be observed between these tribes ; if there is any, the Nascaupees appear to be slightly taller nnd less robustly built than the Montagnais. They talk different dialects of the Cree language, but the difference is so slight, that they converse freely together, and understand one nnother quite readily. The name Nascaupee in the Montagnais dialect signifies "the ignorant ones" and is given on account of their lack of knowledge in regard to the works and ways of civilization, owing to their want of communication with the outside world. 


\section{IIamilton River.}

The Hamilton River is the most important strenm of the enstern Drainge. watershed of the Labrador Peninsulu. Its draingo-basin embraces Inumin of a wide area of the country extending from the heal of Hamilton Hiver. Islet wostward to longitude $68^{\prime}$, or nearly half way neross the peninsula. To the northwarl its tributnries interlock with those of the Northwest River which also tlows into Hamilton Inlet, and with the healwaters of the George 1Rivel and branches of the Koksonk River that empty into Ungava Buy. The soutlern linit of its large tributaries is very irregular, and may be roughly taken to be nenr the fifty-second parallel of latitude, where the watershed separating them from streams flowing southward into the St. Lawrence, is extromely sinuous and almost impossible to trice or define.

Westward of the ILamilton basin, the general slope of the country is northward, and the drainage is in that direction from about latitude $52^{\circ}$, the water reaching the ocean by the lioksonk River, which drains a considernble aren of the central interior between the hend of the Hnmilton River and the Big River flowing into Hudson Bay.

Owing to the great difference in physical character botween its Division of upper and lower portions, the Humilton River is naturally divided river into into two parts at the Grand Fulls somo 250 miles above its lower. mouth. The lower part occupies a distinct valley, cut out of Archean rocks, with the present river-level from 500 to 800 feet below the general level of the surrounding country. The valley varies in width from 100 yards to more than two iniles, and the river flows down it, between bunks of drift, with a strong current bioken by rapids in several places, especially along the upper stretches, but only in one place does it full over an obstruction of rock.

This valley is well wooded where unburnt, and the timber is all of The riverfair size and of commercinl value, in marked contrast to the sinall valley. stunted trees found partly covering the rolling country of the tubleland, on either side of the valley. The river flows into the head of Hamilton Inlet, on the south side, and a long point of drift material, principally sand, projects out into the bay, separnting the river from the head of Goose Bry, which extends several miles west of the mouth of the river on its north side. This point is evidently formed from Inaterial transported from the valley above and deposited in the quiet waters at the head of the inlet.

From the mouth of the river to the first fall, the distance is twenty. seven miles, and the direction is $S .80^{\circ} \mathrm{W}$. At its mouth, the river is 
thirne-quarters of $\mathbf{n}$ mile wide, and shortly nbove widens out to nearly $\mathrm{n}$ unile and $\mathrm{a}$ hulf, for ten miles; then $\mathrm{n}$ nuuber of flut, sandy shonls bnre at low stnges of the wnter, divide it into numerous clunnels. Mnn-of-wur Island lies on the north side flve miles up strenm; it is low nud nbout $\boldsymbol{n}$ mile long, and hns $\boldsymbol{n}$ fow trees growing on it.

On the south side, $n$ mile and $n$ half nbove the mouth, a chnnel enters froon Mucl Jake, a shallow body of wnter two miles long, oxtencling to the foot of the mountains nnd separnted from the river by two low, wooded islands. Alout two miles nbovo Man-of-war Islnnd, on

Traverspline kiver.

Muskrat Island.

Muskrat Full. pours with a chute of twenty feet called Muskrat Full. Above this chute is a heavy rapid 400 yauds long, witl a clute of twenty-five feet, nt its head, the total fall leing seventy feet. At the clintes, where it rushes over ledges of gneiss, the river is only about 100 yards wide. Immediately on the north side of the falls, there is a rounded, rocky hill rising 250 feet above the level of the valley. On the north side of this hiil is a wide plain of fine till. Where the edge of the plain has been cut away to form the basin below the chute, a wide section of over $\mathbf{1 0 0}$ feet of fine till is exposed, without any sign of rock in place. The present channel at the falls is of recent origin, and it is probalsle that previous to the glacial period, the river-channel was filled up with drift material, so that when the river ugain resumed its course, it was diverted from its old channel by the obstruction, and prssed to the south of the hill where the drift deposit was less thick. Having once cut to the rock surface, well below the upper level of the drift on the opposite side, it has continued in its present channel ever since. 
At its mouth, the banks of the river are low and sandy, and have Character of scarped faces from ten to thirty feet high, inerensing sic wly in height river-vallowy as the river is uscended. Terraces are seen to the south, llunking the rat F'all. inountains up to 300 feet ahove sen-level. Above Traverspine the lanks rise from sixty to one huudred feet and are cut out of eonrse, yellowish, stratified sands.

The western extension of the Menly Mountains forms the southern wall of the valloy, and, above the head of the low point separating the river from Goose Bay, rocky hills are seen also on the north side. 'The valley, us far as the first fall, varies in width from two to tive miles, and the river passes close to the foot of the rooky hills on the south side fifteen miles above its outlet. As the vulley has been partly filled with drift, out of which the present channel is eut, it is only when the river accidentally passes close to the rocky wulls of the valley, that any rock-exposures are seen. The hills on both sides rise from 400 to 600 feet above the river-lovel, and partly represent the general height of the surrounding platenu, which rises somewhat higher buck from the valley on both sides. These hills are wooded to their summits, but as the upper level is appronched, the trees become small and stunted, and only a very few species grow on the table-land above. Black spruce forms over ninety per cent of the wood, the remninder being made up of Inrch, white birch and balsam fir.

In the valley, on the contrary, the growth of timber is very good, Timber. considering the position. White spruce trees two feet in dinmeter and more than seventy feet high are not uncommon, and a large number of ship spars have been taken out about 'Traverspine. The black spruce does not grow quite as large as the white, lut is still large enough to afford good commercinl timber, and the same may be said of the larch growing in the valley. Balsam fir, white birch and both aspen and balsam peplar are here met with and grow to fifteen inches in diameter.

Above the chutes the river soon widens out, and for thirty-five miles flows from the south-west. Its average width for this distance is slightly less than a mile. Fonteen miles above the chutes it narrows to less than a quarter of a mile, and is broken by rapids for two miles above. Below these rapids there is a great sandy shoal, which extends across the course of the river and has forced it to cut a deep bay on the south side out of white sand, that rises in almost perpendicular banks over one hundred feet above the water. This place is called Sandy Banks, and the Hudson's Bay Company formerly maintained a Sandy Banks. small trading-post on the north side, where the site of their clearing is marked by a new growth of birch. 
Above Sandy Banks, the strean is again over a mile wide, with a large island dividing it into two cliannels, and a deep bay runs off to the north-west from the muin channel. Above this island the average breadth is half a mile for tive miles, when it again widens to a mile for thee miles, to the foot of the Porcupine Rapids. These rapids ar: neatly three miles long, with a deep channel, the river being about 300 yurds wide. There is good tracking along the banks, and no purtage is necessary to pass this obstruction.

Gull-island Lake.

Terraces.

Valley ahove Gull-island Lake.
Above the Porr, upine Rapids, the river expands again into Gull-island Jake, which is six niles long, and not over a mile wide. The nume is a misnoner, as there is a very perceptible current throughout. Gull Island is a small rocky islet on the south side, about two uniles from the head of the lake. From the Muskrat Falls to Gull Island the character of the river and valley is very similar to the portion below. The riverchannel is wide and shallow, at ordinary stages of the water, and the current is strong, so that tracking is resorted to in ascending with boats. The hills, as far as Gull Island, remain about four miles apart, and theie begin to approach, so that the valley is less than half a mile wide at the head of Gull-island Lake. The height of the hills varies from 500 to 800 feet above the level of the river, and much of their surface is burnt over, with less than half of the north sicie of the valley wooded, with trees similar to those described along the lower stretch.

There are considerable accumulations of drift in the valley, into which the river has cut its present channel. Terraces are common and well marked, especially about the mouths of small streams flowing down from the table-land, on both sides. As many as seven were seen on the south side, below the Porcupine Rapids, the highest being 200 ieet up the flank of the mountains. The river-banks are sandy and steep, and vary from twenty to seventy feet, with a margin of nearly level shore at the water's edge, which affords good ground for tracking. Only two exposures of rock were seen along this course. Several small streams fall into the main river on both sides, but none of them is of any size or importance.

From the head of Gull-island Lake, the course of the valley changes more to the northward and the river flows from $\mathrm{N} .70^{\circ} \mathrm{E}$. for eight miles; the next course is from S. $60^{\circ} \mathrm{W}$. for two miles, and is followed by a stretch of nine miles directly from the south. Along all these three courses, the valley is from a quarter to half a mile wide, with almost perpendicular rocky walls that rise abruptly from the water more than 800 feet, with narrow intervals of drift only in a few places. The river varies from 100 to 400 yards in width, and throughout the dis- 
tance is an almost continuous rapid. Up the stream the Gull Rapid is the first, and extends from the lake upwards for five miles. The water is shallow, and the channel is full of rocky reefs and large boulders, over which it tumbles in foaming musses. Owing to the shallow water, this portion of the river blocks in winter with ice, which is piled up in all directions in great disorder and is quite inpassable with loaded sloi, $h s$, until after sufficient snow has fallen to cover up and smooth out the smaller inequalities. The second rapid is at the bend and is called the Horse-shoe Rapid; it is also shallow and full of huge boulders. Along the upper stretch, the river only in one place exceeds 100 yards in width, where it passes a small island. The chanuel is rocky and the water is deep, so that, although the current is very strong, the water is not brsken, except by a dead swell, until within a mile of the hear of the stretch where a heavy rapid makes it necessary to portage.

At the head of this rapid, a large branch called Minipi River, enters Mivipi River the main stream from the south, through a deep, narrow vailey, down which it rushes with heavy rapids. This stream discharges a large volume of water from its gathering ground on the table-land to the south and south-west of its mouth. It is said to rise in chains of lakes close to the head-waters of the Natashquan and St. Augustine rivers which flow into the Gulf of St. Lawrence.

Between Gull-island Lake and the Minipi River three-fourths of the timber in the valleys and on the hills of botli sides has been burned, much of it by a great fire that raged throughout the summer of 1893 . In the green woods remaining, many large spruce trees were seen, from. twenty to twenty-four inches in diameter, and sufficiently long to furnish three logs each. A few narrow terraces were seen on the hillsides, but owing to the scanty difift leposits there is not much chance for the development of ierraces.

Above the Minipi, the main stream bends sharply, and for twenty- River-valley five miles fluws from $\mathrm{N} .80^{\circ} \mathrm{W}$. The valley gradually widens out and above the to the upper end of the course varies from one to two miles across. Its walls continue to rise from 700 to 900 feet above the water, and are nearly everywhere burnt bare. Terraces again becone well marked and numerous, and range from 20 to 250 feet in height. The river channel is sut out of the drift, and the banks rise from ten to one hundred feet ahove the stream. The river, for five miles above the forks, is. never more than 300 yards wide, and then widens to about a quarter of a mile, and is broken by a small shallow rapid where it passes four well-wooded islands, three miles up. Beyond the islands, it narrows again for four miles, and from there wo the end of the course 
it passes what is known as the "slack water," where the width varies from 400 to 600 yards in a deep channel with gentle current. There are three large islands along the upper three miles, with another called Cockatoo Island four miles below. Two large brooks come in from the north near the niddle of the course; the lower one issues from a deep cut in the hills. On the soutl side a small river flows in at the upper end above the islands. Both sides of the valley is almost, wholly burnt to within a few miles of the upper end, where the north side is well wooded with somewhat smaller trees than those previously met with.

The valley now bends to the north-west for five miles, and then northward for ten miles to where a snall river flows in from the north-east. Along these courses it does not anywhere exceed one mile from side to side, and the hills are particularly ligh and rugged on the west side, where they rise from 800 to 1000 feet almost perpendicularly from whe water. They are well wooded on both sides to within a short distance of the snall river, where the eastern limit of an immense Great area of area of burnt countiy crosses the valley. This area, which exiends on burnt land. both sides of the valiey almost to Grand Falls, has been traversed by numerous fires during different years, so that, with the exception of isolated patches here and there, all the original forcst has been destroyed, and the sides of the valley and adjoining table-land are either destitute of trees, or partly covered with smell second-growth timber of no commercial value.

Along the first or north-west course, the channel is only about 300 yards wide, and is obstructed by a number of small islands of drift. The current is strong, and there is a small river that drops into the valley with a beautiful fall on the west side near the head of the course. Above, the channel widens to a quarter of a mile, and the river is shacllow, with small rapids to the upper end of the north course.

Cîche River. The stream that here flows in from the north-east, called Cîche River, is the largest yet seen on this side, and it has a distinct valley cut down between the rocky hills to a level with that of the main stream. Terraces are not prominently marked along the portion of the river just described.

For the next twelve miles the valley is narrow and very crooked, with siarp bends and a general course north-westward. The rocky walls rise sharply on botl sides alrnost directly from the water, leaving in most places only a narrow margin of steep shore. The hills are nearly all bare and rocky. Terraces are not common, and are best developed at the junction of a small branch from the west about eight miles up, where the terraces are seen rising one above another for 250 feet. 
The river varies from 100 to 300 yards across, and is deep and so Mouni rapia that in winter ice is formed only along the shcies. The Mouni Kapids. Rapids are two miles long and have three heavy pitches it the upper end.

The valley above straightens, and the river flows $\mathrm{S} .80^{\circ}$ E. from Lake Winokapau six miles above. The stream continues narrow and rapid to the outlet of the lake, and is joined by a small stream five iniles below it. Towards the lake the sides of the valley continue to increase in height, until at its outlet bare rocky precipices tower above it 1000 feet or more, with great masses of broken rock piled up at their base. Only a few sinall trees grow in cracks on the sides and top; and the general aspect is wild and grand.

Beyond the valley on both sides, the country is covered with broken chains of rounded hills of gneiss that rise from 200 to 500 feet above the general level of the table-land, which is itself over 700 feet above the surface of the lake. The lower lands are either swampy or covered by small irregular lakes tha', discharge by streams into the valley, where they often fall perp ndicularly 500 feet down the rocky walls. During the winter thes streams freeze up, and their positions are marked by massts of ice often attached in fantastic forms to the bare surface of the rocks. In other places where the slope is less, the water wells out from below the already formed ice and congeals on its surface, in this manner forming large ice ccnes.

The table-land is almost denudad by fire, only smail patches of trees being left about the lakes and swamps. These consist of a thick growiti of stunted black spruce and larch of ne vommercial value.

Lake Tinokapau fills an expunsion of the river-valley, and is thirty- Lake Winofour miles long, its general course be:ing N. $80^{\circ}$ W., with two slight kapau. bends near its middle. For fifteen miles from it : outlet it does not exceed a mile in width. Beyond, to its head, the breadth varies from one and a half to two miles.

From its outlet, the nor th shore, for six miles, has a nurrow margin of drift between the water and the rocky hills. Beyond this, and all along the south side, the rocky walls of the valley rise abruptly from the lake, and there is a marked absence of drift both on the hillsides and in the valley.

The water is remarkably deep; an isolated souiding taken fifteen Great depth of miles up the lake, and about miclway across, gave $42 i$ feet, while an- the lake. other taken by Mr. Bryant* gave 407 feet. A third sounding was

*A journey to the Grand Falls of Labrador, 1, 26. 
made fifty feet from shore on the south side, opposite the first mentioned, and gave a depth of 80 feet. No other soundings were made, owing to the difficulty experienced in cutting through the ice, which at the time we passed was four feet nine inches thick, and two hours wer6 required to make a hole through it with the implements at hand. Information obtained from Indiuns shows that the lower three-quarters of the lake are exceedingly deep; the unper quarter has been filled $i_{n}$ with drift brought down by the river.

The present bottom of the lake probably nearly represents the level of the river previous to the glacial perind, the valley below having been in places filled with drift during th. sime to levels indicated by the terraces seen along the sides of the valley, rising in places from 200 to 250 feet above the present river-bed. The absence of any rocky ledges in the river-bottom, except at the first falls, where the ancient channel is on the north side of the rocky hill, points to this conclusion. Why the valley should be filled witl drift below and above Lake Winckapau, and the portion occupied by the lake should be almost free of it, is a problem in glacial geology to be worked out in the future, but for which there are at present no datí.

A small isiand of drift, covered with willows and a few large white spruce trees, six miles from the head of the lake, marks the heginning of the shallow portion. Above the island there are numerous wide, sandy shoals, bare at low stages of the water, and separated from one another by narrow channels. The main channel passes close to the south bank, and two large, low, wooded islands of drift separates it from a smaller shallow channel on the nortl side. At the head of the lake, n

Flizabeth River'.

Ancient Hudson's Bay
post.

Character of surrounding country. small branch called the Elizabeth River flows in from the west, down a narrow valley, while the main valley bends to the north-west.

On the south side, at the mouth of the Elizabeth River, there is a wide, sandy plain - bout twenty-five feet above the river, and on it the Hudson's Bay Company formerly had a post, which was abandoned in 1873 , and subsequently destroyed by fire. A small river flows into the lake from the south opposite the lowest island, and the drift on the hillsides is terractd up to 200 feet about its nouth. On the north side, there are three large brooks with deeply cut valleys, and one on the south side; besides these, there are many small streams that fall directly over the precipices, from the toble-linnd above, breaking the monotony of the rocky walls, and adding greatly to the beauty of the scenery.

The hills that hound the valley on its south side are remarkably regular in outline end have been rounded and scratched by glacier ice. 
Low. ]

Those on the north side often rise in perpendicular cliffs from the lake; their faces and tops are angular and rugged, and do not appear to lave been glaciated. The walls on both sides are from 700 to 1000 feet high, gradually lowering towards the head of the lake, where the slopes ure less abrupt and the hills more rounded. At the head of the lake, the general level of the table-land on the south side is 950 feet above it. The country on top is nearly level, and covered with small lakes. Ten or fifteen miles to the south, a conical hill rises about 500 feet above the table-land. On the north side after an abrupt rise of 400 or 500 feet, the land slopes gradually, and does not attain the elevation of the south side for several miles back from the valley. Only a few smill scattered clumps of trees remain of the original forest in the lake-valley; these show that at one time the shores and sloping hillsiles were thickly covered with large trees of white and black spruce, up to thirty inches in diameter. At present most of the hills are bare, or covered only with small second-growth spruce and birch. The table-land to the southward is quite bare of trees, only the blackened stumps of the former forest remaining. On the north side, bare patches alternate with scattered second growth black spruce of small size.

Lake Winokapau is well stocked with fish, the employees of the Fish. Hudson's Bay Company when stationed there, depended to a large extent on fish for food. In the old journals* of the post, the catches of the nets are recorded, and show that fish were taken abundantly, especially in the spring. The catch included carp, whitefish, lake and river trout in the order named. Potatoes and turnips were grown at the post, but not very successfully, as after planting in the spring, everybody left the place, and did not return until September, leaving the crops to grow without cultivation.

From the mouth of the Elizabeth River, the main valley turns Metchin $\mathrm{N} .40^{\circ} \mathrm{W}$., and continues in that direction five miles to the mouth of River. the Metchin River, a small streun having a deep valley, and used as a canoe route to the north-west interior by the Indians. Along this course the valley is about a mile wide, with the hills more rounded and sloping than below, owing to the great quantities of drift deposited here, through which only the rocky summits protrude. The river is less than half a mi'e wide, and flows close to the north side to within half a mile of the Metchin, where the deposits brought down by that stream have formed a low plain, and have forced the main stream into a narrow channel close to the south wall. Terraces are common and rise to more than 200 fcet above the river.

*Winokapau journals seen at Rigolet. 
'The course of the valley now changes to N. $70^{\circ} \mathrm{W}$, and with a few minor bends, continues in that direction for forty-five miles to the foot of the Bodwoin Canon below the Grand Falls.

The narrow channel continues for a half mile above the mouth of the Metchin River, where it widens out to an average width of 500 yards, with high rocky walls on the south side, and drift-covered slopes on the north side. Six niles further up, there is a sharp bend to the north ward for one mile, when the river again resumes its previous course. At this bend, the walls on both sides exceed 800 feet, and those on the west side rise in perpendicular cliffs directly from the river, which

Character of the valley.

Portage River. is here 400 yards wide. Above the bend, the character of the valley is unchanged for twelve miles, the valley being from half a mile to a mile wide, with high rugged hills, mostly burnt, on both sides. The channel is cut out of the drift, and is more irregular in width than below, being frequently narrowed by projecting points. The current is swift and the water appears to be deep. Seven miles up, a small branch flows in from the northward, in a gorge cut down to the level of the main valley.

After two well-wooded sandy islands are passed, another sharp bend of a mile to the northward, opens out into a wider valley entirely filled by the river, where there is little drift on the hillsides or along shore. The river is very shallow and the current swift. This stretch is seven miles long, and at its head the channel narrows to less than 200 yards, owing to the amount of materiai brought down by the Portage River, which cuts through a cliff and descends into the valiey by a fall of nearly 200 feet, that is almost hidden by the huge blocks of rock heaped up at its bottom. Shortly above the Portage River, the main stream again widens out, filling the valley from wall to wall, and varying from half a mile to one mile in width for eight miles. The portageroute of the Grand Falls, leaves the valley on the north side four miles above the mouth of the Portage River.

Opposite this place and above it, the river is silted up with sand brought down by rapids and deposited in the wider, quieter waters. This sand forms wide flats, covered at high stages of the river, and cut by numerous, deep, winding channels. Four miles above the portage, two large, low, densely wooded islands mark the foot of the rapids that extend almost continuously beyond for twelve miles, to the mouth of the cañon. The channel above the islands soon narrows, and the drift deposits thin out, finally almost wholly disappearing from the sides of the valley, which contracts to less than 300 yards in width and becomes. crooked. Three miles above the upper island, the first rocky ledge since 
leaving the Muskrat Fall, is seen in the river bottom. Here, there is Disanter a heavy rapid which continues balf a mile to a short bend to the west- Rapicl. ward. At the foot of the rapid, Messrs. Cole and Cary, of the Bod woin College Expedition, had the misf , rune to burn their boat and supplies, and on this account it has beeu called Disaster Rapid. The charred remains of the boat was found close to the shore in a small patch of burnt woods.

Two miles above this rapid, at the angle of a small sharp bend, a Unknown large branch flows in from the west in a well defined valley. Inquiries made among the Indians who had hunted about here, failed to yield any information concerning this stream, and they were surprised to hear of its existence, as they all were without knowledge of any large stream between the main river and the Elizabeth River, which enters Lake Winokapau. The only explanation given about this unknown stream, was that it must be a deep channel of the Valley River, and must leave that strearn some distance above the main forks ; but the origin and existence of t:vo deep, well defined valleys such as these, forming an island, is anomalous, and could only be accounted for by the river splitting into two branches before it leaves the table-land.

Above the junction of this stream, two sharp bends of the narrow main valley lead, after three miles, to a long straight stretch, where the valley widens somewhat, and patches of terraced drift are seen high up its rocky walls. At the upper end of the last bend, a small stream comes in from the ncrth, descending in a succession of beautiful cascades from the table-land 700 feet above. This stream drains a number of lakes, and when the river is swollen by the spring freshets, a small portion of it passes up a narrow bay above the Grand Falls, and from there by $a$ rocky channel into the small lakes, of which the discharge is this much increased during the early spring.

For tive miles above the junction of this stream, the valley continues straight and narrow, with sandy terraces flanking the rocky walls at intervals along both sides. The river varies from fifty to one hundred yarcis in width, and rushes along in a continuous heavy rapid, from where the main body of water enters the valley by Bodwoin Cañon.

A bove the mouth of this canon the main valley continues in the same Main valley direction upwards of ten miles, and then bends slightly northward, its above Bodfurther extension being concealed by the high walls on the north sicle. As far as seen from the cañon, the valley uppears to be from a quarter to half a mile wide, and is partly filled with terraced drift, with a branch flowing with a moderate current down it. This branch has ?ass than a quarter of the volume of the other river, and rises in Lake 
Ossokmanuan on the table-lund, thirty miles to the westward. This lake also discharges b: another outlet into the unain Hamilton River, bescent of the c'escrihed later. Eigl - miles in a straight line north north-west of the river near the mouth of the cañor, the main brunch of the Hamilton River issues from a small lake-expansicn, almost on a level with the surrounding suryace of the table-land, ard begins one of the greatest and wildest descents of any river in easiern America. A large number of barmeti ic readings taken in the vicinity, in conjunction with regular reading; at the Hudson's Bay Company's post, at Nortliwest 1River, give the $h^{\circ}$ ight of the river as it issues from the lake as 1660 feet above sea-leve. The height of the valley at the inouth of the gorge, determines in the snme manner, is very close to 900 feet above sea-level. Consinent!y, in twelve miles, the total fall is 760 feet. Such a fall would be nothing extraordinary for a small stream, in a mountainous country, but is phenomenal in a grent river like the

Volume of water at

(irand Falls.
Hamilton, which has been estimated to discharge at this point nbout 50,000 cubic feet per second, or nearly the mean volume of the Ottawa liver, at Ottawa, that stream having a mean volume of 85,000 cubic feet per second at Grenville, ${ }^{*}$ where it includes the waters of the Rideau, Gatineau and Lièvre rivers. The descent includes a sheer fall of $30: 2$ feet, the rest being in the form of heavy rapids.

The outlet of the lake is lotted over with small rocky islands, capped with dense thickets of small evergreens. These island's axtend downwnrd for a mule and divide the river into a number of nurrow channels with a sw.ft current. The stream, flowing southward, then narrows to less than 400 yards, and in the next mile passes over a number of rocky ledges between low wooded banks, falling fifty feet in a continuous heavy rapid. Again it widens out to nearly a mile, and for two miles is obstructed by many sinall islands, flowing swiftly between them, with short broken rapids. Next, turning south-east, it contracts to less than half its previous width, and rushes along with heary rapids, in a shallow chinnel full of huge boulders, with low rocky shores, capped with thin deposit of coarse gravel and sand, and wooded above with small spruce and larch. In this manner the river contirues for three miles, gradually narrowing as it descends, with a fall of forty-five feet along the last two courses. The banks and bottom of the river are wholly formed of rock, and as the stream in the next mile has cut a narrow and gradually deepening trough out of the solid rock, at the lower end of the course it flows in a narrow gorge, with sloping rocky walls 110 feet below the level of its upper end. As it descends

*General Report Public Works, Canada, 1867-1882, p. 840. 
its width decrenses from 150 to 50 yards, and it hurries along with tremendous rupids.

The last 300 yards are down a very steep grade, where the contined Grand Falls. waters rush in a swirling mass, thrown into enormous, long surging waves, at least twenty feet from crest to hollow, the deafening no'so of which completely drowns tlie heavy boom of the great falls immeiately below. After a finul great wave, the pent up mass of water is shot down a very steep incline of rock for 100 feet, where it breaks into a mass of fonm, and plunges into a circular basin below, the momentum acquired during the first part of the fall being suffieient to curry it well out from the perpendicular wall of rock at the bottom, leaving almost a free passage between the foot of the eliff and the falling water. The total fall from the crest of the incline to the basin below is 302 feet. The Indians believe that the space between the falling water and the rocky wall is occupied by the spirits of two maidens who were accidentally carried over the falls, and who now pass their time in dressing and preparing deer skins. (n this account, or more probably because of the feelings of awe inspired by the grandeur of the surroundings and the enormous power displayed in this rush of waters, those who hunt in the vicinity caunot be induced tr. visit the falls or the cuinon below.

The shape and character of this fall resembles closely, though on a Character of gigantic scale that of a sirall stream flowing down a V-shaped trough, the fallw. inclined at a high angle, ano issuing freely from its lower end. The basin into which the river precipitates ltself, is nearly circular and about 200 yards in diauneter. It is surrounded on all sides by nearly perpendicular rockv walls 500 feet high, except at the narrow cut at the head of the falis, and where the river issues from the basin. The sur. face of the basin is violently agitated by the rush of water from above, and its huge lumpy waves break high up the rocky walls. The falls are best seen from the top of the south wall, directly opposite, but the dense columns of vapour that rise out of the basin often interfere with the view, and give a blurred, fogged appearance to photographs taken from that side. The noise of the fnll has a stunning effect, and, although deadened because of its inclosed situation, can be heard for more than ten miles away, as a deep, booming sound. The cloud of mist is also visible from any eminence within a radius of twenty miles.

The river leaves the basin by a narrow cañon at right-angles to the Bodwoin falls. It flows eastwird about a third of a mile, and then bends Canion. sharply to the south-west for a half mile, next to the east for a like distance, followed by another south-west bend of similar length. 
In this manner it zigzags until it finally ends in the main valley of the river.

From the falls to the mou'll of the enñon the distance in a straight line is not nbove four miles, but by the river it is over twice as far. This canon is cut down into solid gneiss, granite and gabbro. Its zigzag course eonforms with the direction of two sets of frncture, or eleavage-planes in the rocks, which appear to have enused lines of weakness and aided the eroding action of the water. Fxcept on the inner sides of the bend, where there is a sloping wall of boulders, the walls are nearly perpendicular. At the top, the width rurely exceerls one hundred yards; while at the bottom the river is seldom over one hundred feet wide, and often measures less than half that width. The fall of the river from the basin to the mouth of the canon is 260 feet, and, as this is accomplished without any heavy drops, the magnitude ana grandeur of the rush of vater at the bottom of the gorge may be imagined.

The cañon is cut sharply into the surface of the table-land without any appreciable dip of the ground towards it, and there is so little indication of its presence from above, that the gorge is seen only within a few yards of its edge; and its walls ure so steep, and the bushes along the top so thick, that in most places it is necessary to hold on to an overhanging tree and lean far out in order to see the narrow white line of broken foaming water that rushes along 500 reet below. As the country slopes gently towards the main valley, the canon does not deepen with the descent of the river in it, and the walls are everywhere from 500 to 600 feet high, varying with the undulating surface of the table-land.

Origin of Rodwoin Cañon.

There is little doubt that the cañon is a valley of erosion in an unfinished state of formation, and probably previous to the glacial period was the valley of a much smaller stream than the one at present flowing through it. At that time the main stream in all likelihood followed the main valley. There is no evidence that the valley has been cut back, or otherwise eroded since the close of the glacial period, beyond the removal of the drift, which then filled it nearly to the top, rs patches of drift still remain on the inner sides of the sharp bends. From the above facts some idea ean be had of the great length of time required for the erosion of the main valley of the river, from the falls to the mouth of Hamilton Inlet, which is really a submerged portion of this river-valley.

John McI.ean. John McLean, of the Iudson's Bay Company, as before stated, was the first white man to see the fall. In 1839 , while on a journey over- 
land from Ungava Bay to Hamilton Inlet, he descended the Hamilton River, visiting the fall in passing, and he has given a short description of it in his book. ${ }^{*}$ The falls ure known to the Indinns and inhabitunts of the Labrador coust as the Grand Falls, but as a recognition of the discoverer, as well as the indefinite character of the above name, it is now proposed to call thom the Grand or McLean Falls.

' The cuñon below the falls was first discovered and purtly traced by Messis. Cary and Cole in the summer of 1891 , and was named by them Bodwoin Cañon. Mtessrs. Bryant and Kenason also visited the fall in 1891, arriving there a few days later than the first party. Among others of the Hudson's Bay Company officers who have seen the fall, may be nientioned a Mr. Miclherson, who visited them shortly after their discovery by McLean, P'ere Babel, O.MI.I., a missionary who spent two or three seasons living with the Indians about the heacwaters of the Hamilton River about 1870, has also given the writer a most graphic account of his visit to the fall at that time.

The portage-route past the fall and rapids, leaves the main valley on P'ortuge-route the north sicle at the foot of the rapids fifteen miles below the mouth fantthetirand of the cnñon. The road rises 700 feet in $n$ quarter of a mile as it ascends the steep wall of the valley by a narrow cut beside a small stream. It then pnsses over undulating wooded country, rising slowly for two miles, to a small lake that lies north-west of the lower end of the portnge. Crossing the eastern end of the lake, the route turns nortliward and passes over four portages of 1000,200, 200,300 yards long respectively, that connect as many small lakes or ponds. The last portage ends near the iniddle of Island Lake, which is about three miles long and a mile wide, $w i$ th its longest axis running almost east-andwest. This lake discharges from its east end into another large lake that empties into the Portage River. Crossing to the rorth side of Island Lake, two short portages, with a small swampy lake between, lead into another lake about two miles and a half long, which also discharges into the Portage River. The route now changes to west-northwest, and continues in that direction until it reaches the lake-expansion of the river above the falls. From the western end of the last lake a mile portage through a swamp leads to a narrow lake one mile long, with another mile portnge from its w est end into a similar narrow lake. The next portage is slightly shorter, and crosses a small watershed, passing close to the foot of a high hill on the south side ealled Lookout Mountain; it ends in a long narrow bay at the east end of Lookout Lookout Lake, the largest body of water along the route. This lake is followed Mountain. seven miles, to its western end, where a small river enters. The

* Twenty-five years in the Hudson's Bay Territory. Vol. II., p. 75. 
grentest brealth near the enst end is less than two miles. The lake is slinllow and dotted with small roeky islnnils. It dischnrges by the little river that falls into the main vulley five miles below tie cañun, and which, as alrenly ma ationed, forms a discharge of the man river during periods of high wa, $r$.

The inlet is followed throw a number of lake-expunsions for tive miles, with three short portngis past rupids und a finnl ono of 1 linlf mile that leads to the hem of $n$ deep bay of the main river.

Lookout Mountain is a long round hill of gabbro, thut rises 160 feet Comutryalnut above Lookout Iake. Its summit and sifles have been burnt over, Limkinit Momutuiu.

funl from its top a good view of the surroumling country may be obtuinerl. The surfuce of the table-land is broken by long rocky hills, connected by low ridges of drift, thut run west-nortl.-west, or parallel to the direction of the glacial stria. Between the ridges there are wide valleys filled by long irregular lakes or swumps. Soutliward from the top of Lookout Mountuin, the country is seen sloping townrds the river-valley, and it is much more broken and rugied thmn in other' directions. One shurp rugged hill rises well above the rest, and is probably the Mount Hyde of the Bodwoin Experlition.

The position of the river-valley here is well marked, the comntry sloping towards it on both sides. Beyond the valley, the country appears to be somewhat higher than on the north side. Ranges of burnt hills are seen stretching away to the south-west, and bounding the horizon in that direction. Westward, the position of the Grand linlls is marked by the column of mist that rises high over it. No other feature marks the presence of the ennon, nnd gently undulating hills extend as far as ean be seen. To the north-west, the country is vely similar, and in the distance lake-expansions of the river appear. North and north-enstward, the ridges of hills are seen running in regular lines with a higher runge bounding the sky-line nbout twenty miles away. Where any depression occurs in the ridges, a shining patch of water marks the position of a lake, in the valleys beyond. Looking south-enst, or parallel to the ridges, a perfect network of small island-dotted lakes are seen, filling euch valley, and separated from one another only by low ridges of drift. In the distance are a number of high rounded hills near the diseharge of the Portage River.

Trees. Over half of the surrounding country has been stripperl bare by frequent fires. In the swamps and around the shores of the lakes, where the trees are unburnt, black spruce and larch of small size grow thickly together. On the sides of the hills these trees are more 
stunted, and are separated by open glacles. Where the hillsides have been burnt years ngo, they are covered with a tangled muss of willows and alders, while the tops are coated with white inoss and semi-arctic slurubs and berries. Only on the banks of the river about the falls were trees large enough for commercial purposes seen. Surrounding the busin, white spruce seventy feet high and two feet in dinmeter nt the base, are common, along with large-sizel hlack spruce, lanlsam fir and white birch. The moisture from the constant column of spiny, as well as the wurmth from the open water, may account for the better growth of the trees in the neighbourhowl. Along the river banks and on the islands above the fulls, the trees are lniger, and more vuried than about the lakes of the portage-route, fair-sized white and lilack spruce, balsnm fir, larch and white birch growing freely.

\section{Upper Hamilton River.}

Above the Grand Falls, the charncter of the river ehanges com- Charneter of pletely ; it no longer flows in a distinct valley cut deep into the sur the upper rounding country, but nearly on a level with the surface of the table. Miver. land, spreading out so ng to fill the valleys between the long, low ridges of hills that are arranged in echelon all over the country. The river in passing around the ridges is often broken into several chumels by large islands formed by separate ridges, and in other places, where there are wide valleys between the lills, it fills long, shallow lakes, with deep lanys, and often studded with islands. The river is now so divided into channels and so diversified with islandcovered lnkes, that without a guide it is almost impossible to follow its main channel, and much time is lost tracing its course through the lnkes, which often have several channels discharging into, as well as out of then. The current instend of flowing regularly, now alternntes between short rapids and long lake stretches.

The banks are often low, and covered with a dense growth of small willows and alders, that form a wide fringe between the water and the conifers of the higher ground behind. In other plnces, generally at rapids, the stream has cut a chunnel into the sandy drift that forms the low ridges on one or both sides. The shores of the lakes are very often low, with an interval of flat land between the water and the hills behind. These low shores and those of the islands are generally thickly strewn with koulders, piled up in ridges by the expansion and drift of the ice in the spring. The general direction of the river from the Grand Falls to Lnke Petitsikapan, more than 100 miles above, is. 
nearly west-north-west, or parallel to the dircction of the glacial strie,

Post-glacial channels.

and that of the ridges of drift. All these features give to the upper portion of the river an aspect of newness, and indicate that its present course and conditions have been determined by the post-glacial configuration of the table-land, in marked contrast to the ancient appearance of the deep, rock-walled valley of erosion below the cañon in which the river must have flowed for ages, slowly abrading the hard gneisses and granites and carrying away the results of atnospheric decay brought down from its sides by the rains and small tributary streams.

Jacopie Lake. The first expansion of the river above the portage is called Jacopie Lake. It is seven miles long and about two wide, with two deep bays on the east side, and is surrounded by low, rounded, rocky hills, totally burnt over on the east side, and partly so on the west. A chain of low islands of drift extends along the enst side, and almost closes off the bays from the main body of the lake. In a few places, bosses of rock are seen rising from beneath the drift of the islands. At the head of the lake, the current is quite strong in the main channel, with a beavy rapid at the inlet, in order to avoid which, when the water is high, a small channel behind a long narrow island is followed by canoes. There are two short portages here past small chutes.

Ahove the lake, is a stretch of eight miles where the river flows swiftly and is broken by two leavy shallow rapids filled with large boulders. The banks are generally low, and are cut out of drift, the channel averaging haif a mile across. Numerous islands divide the stream into different cliannels, especially towards the upper end, where the river broadens out into the next lake-txpansion. This is called

Fluur Lake. Flour Lake, and it is ten miles long and apparently about two miles wide, with deep bays running off on both sides. Its surface is so broken by islands, many of them small and rocky, that it is impossible to determine the shore-line of the lake by passing up its middle. There is distinct evidence of current everywhere, and thi 3 grows stronger as the head of the expansion is approached. At the upper end the river splits into two nearly equal channels, that do not again join until Sandgirt Lake is reached, fifteen miles above. The nortl channel is very rapid, and soon leads into Lobstick Lake, a large and long body of water on the route to Lake Michikamau, described in the part of Channel from the report referring to that lake. From Lobstick Lake, a stretch of Lobstick Lake. five miles of river leads into Sandgirt Lake, where the streams again unite.

The south channel, leading out of Flour Lake, is the ordinary canoe route. The distance by this channel between Flour and Sandgirt lakes is fifteen miles. The strenm varies from 100 yards to over a 
mile in width, nad is obstructed by numerous islands. The surrounding country is 'uw and rolling, with long ridges of drift and little rock. The trees are small anci are principally black spruce and larch, with white spruce and brioam $f_{A i}$ along shore, and white birch on the hillsides. The curcent is alwajs strong, and it is broken by seven short. heavy rapids, where the stream narrows and is obstructed b.- islands. The river-bed at these rapids is composed of large, rounded boulders.

Five miles above Flour Lake, the south channel again divides, and the canoe route continues to follow the southern branch, which flows out of a deen bay in the south-east corner of Sardgirt Lake, the other channel flowing out of the next bay a few miles to the northward.

Lake Kanikauwinikau or Sandgirt Lake, is an irregular-shaped: Fandgirt shallow iody of water, with many islands of drift and with sandy or boulder-strewn shores. It is twelve miles long from the southern outlet to the mouth of the Ashuanipi Branch, on its rorthwest side, where two deep bays continue on several miles farther to the westward, one on - each side of the river, and divided from it by wide low point: of drift. From the mouth of the Attikonak Brinch, on the south-west side, to the northern ouilet, the distance is eight miles. Beside: the two bays on the west side already mentioned, there are two others, one to the south and the other to the north; these are only a few niles deep, with small s,treams flowing in at their heads from wide-spreading series of lakes. The country surrounding the lake is srmewhat higher than that along the river below, especially on its soutil side, where a ridge of rocky hills extends from the east to the sinores of the Attikonak Brancl. Some twenty miles westward, a wide range of hills is seen rising with barren sides over 800 feet above the general level, and it continues in a no:th-western direction. The outlines of these hills are sharp and rugged, cuite unlike those of the hills of the Archean aren already passed through. Only their lower slopes are wooded, and in the month of August large masses of ice and snow remained in protected gullies on their northern slopes. The name of ice Mountains was given to these hills. To the north-west, rounded hills from 200 to 500 feet ligh are seen, separated by wide valleys containing the bays on that side of the lake. To une north and north-east, the country is undulating and lower, with higher, rounded ridges bounding the horizon. To the east, only low ridges of drift break the general level.

Sandgirt Lake is an important gathering place for the Indians of the interior, on account of the number of routes that centre here place of The Hamilton River divilles into two branches, the larger or Ashua- Indians. nipi Branch flowing in from the north-west and the Attikonak Branch $10 \frac{1}{2}$ 
from the south. The main route from the Hamilton River to Lake Michikamau also ends here. The Indians who trade on the lower St. Lawrence and hunt anywhere in this vicinity, always congregate here in the spring, and descend to the coast in company, either by the Romaine or Moisie River.

Returning in the autumn, they travel together to this lake, where they separate into small parties for their winter hunts. The standing poles of their wigwams, scattered everywhere along the shores and on the islands of the like, show that several fauilies camp here.

On account of its favourable situation, a câche was made on an island in the lake, to store the surplus provisions and outfit, and from here, with lightened canoes, the Ashuanipi Branch was first explored, after which a trip was made to and around Lake Michikamau, before Sandgirt Lake was finally left by the Attikonak Branch.

\section{Ashuanipi Branch.}

Ashuanipi River.

Ice Mountains.

Increase in size of trees.
The Ashuanipi Branch, as before stated, flows into the lake on is west side. Its course for thirty miles above, to Birch Lake, is nearly north-west. For five miles above ilandgirt Lake, the river flows through a flat, well-wooded country, and ther passes close along the southern base of a sharp, rocky hill 300 feet high. This has been ournt over, giving an unobstructel view $f_{1}$ om its summit. The bay of the lake to the northward comes close to the base of the hill, and extends some miles westward of it, where the continuation of the valley is filled with a large treeless swamp. South-west of the river, a network of large lakes occupies over half of the area between the river and the Ice Mountains, some ten miles distant. From this hill to a small lake-expansion four miles above, the river varies from 100 to 500 yards in width, with sandy banks from ten to sixty feet high, cut out of the roughly parallel ridges of indistinntly stratified drift, between which it flows with a swift current. The lake-expansion is about two miles wide and over three miles long; it is quite slallow, with low, willow-clad banks.

A stretch of five miles of sivift water, terminating above in a short rapid, separates the last from the next lake-expansion. A number of high islands of drift obstruct the channel, and the banks are again high and irregular. Occasional white spruce trees are met with along the river bottom, up to fifteen inches in diameter, along with small black spruce, larch, balsam fir, white birch, and a few clumps of small balsam poplar. 
The next lake-expansion is eight miles long; its lower half is crowded with low islands, covered with willows; the shores are also low, with a wide fringe of willows and alders between the water and the trees behind. There is a long ridge on the nortb side, culminating in a rocky hill 300 feet high at its west end.

The increase in the size of the trees about this lake is very marked, and is probably due to the change in quality of the soil, caused by the disintegration of the Cambrian rocks, which here underlie the surfave deposits and form a very large percentage of the drift.

White spruce thirty inches in diameter at the bese and forty feet high is not uncommon along the shores, black spruce is often twentyfour inches in diameter at the base, but rapidly lessens above, so that few exceed eighteen inches six feet from the ground. Balsam fir is abundant, but not very larg? White birch is also common, and grows up to ten or twelve inches in. diameter, but is generally crooked and does not afford good bark for canoe-building. Snall clumps of balsam poplar are met with frequently with trees six inches in diameter, but crooked and straggling like the birch.

At the head of the lake-exp:lnsion, an island seven miles long divides the river into two channels, with the greater part of river flowing in the northern one. The island is formed by a high ridge of drift into which the river has cut deeply in many places, giving sections of from twenty to sixty feet, and showing that the material is almost wholly sund, with evidence of bedding. In places the banks are cut inte small terraces up to a height of sixty feet, in one place to the number of eight.

The noith channel varies from 200 to 300 yards in width, is dotted with small islands of drift, and has a swift current with strong eddies behind sharp boulder-strewn points. All these eddies swarm with large brook trout from three to six pounds in weight. Five miles up, the Birch Lake. channel widens out and is split by a number of large low islands as Birch Lake is entered.

The shape and size of this lake are well seen from the summit of a sharp rocky ridge that extends for two miles along its south side near its western end. This ridge is very similar to others that now run south-east and north-west, parallel to one another, with wide valleys between them. The hill consists of stiatified Cambrian rocks, highly Character of tilted, and has cliff-faces on both sides with intervals covered with ccuntry about drift resting on the steep slopes. The summit of the ridge is irregular and narrow, so that almost anywliere the foot of the hill can be seen on both sides from the top. The sides, where unlurnt, are covered with large white spruce in open gla tes to within a hundred feet 
of the top, where they give place to a thick tangle of willows and alders. On the top the willows are smaller, less matted, and do not interfere greatly with travel. The higher points are only covered with small shrubs, including the cranberry (Vaccinium Vitis-Idea) that grows in great profusion. The highest point of the ridge is about 350 feet ahove the water.

Birch Lake is ten miles long from the northern outlet to the mouth of its southern inlet, and is less than five miles across in its widest part. Long ridges of drift form deep bays at both encls. The large islund already referred to divides the eastern end into two bays, while a long string of islands separates off another portion of the lake on the north. The western end is also deeply indented by three narrow bays that develope into channels of the river at their heads, and thus form two large islands that extend to the next lake to the north-west.

Cambrion ridges.

The north side of Birch Lake is bounded by a sharp ridge extending the whole length of that side. Its height varies from 300 to 400 feet; its top and the greater part of its south side are treeless, the lower parts haring been burnt over many years ago, and the conifers have since given place to willows and alders. Fires have devastated much oi the country surrounding the lake, and, as the trees once destroyed appear to grow again very slowly, large areas have a barren, desolate appearance; they are covered with small bushes and shrubs, and in many places. only with white reindeer moss. This moss, or rather lichen, covers the ground everywhere, even in the thickest woods, and, except in wet weather, is much more agreeable under foot than the tangled masses of Kalmia and Labrador tea inet with throughout the country to the southward. On the islands nnd sliores where the forest is unburnt the trees are very similar in size to those last described. To the south of the ridge there is a wide valley stretching far away to the south and south-west, broken only by low ridges of drift and streaked everywhere with water--parts of large irregular lakes-the view from the ridge giving an impression that over one half of the surface in those directions is covered with water.

The southern inlet of Birch Lake appears to be the largest ; it varies from 100 yards to nearly a mile in width, and is greatly obstructed by low, sandy islands, with shale beneath. The channels are shallow, and the current strong, with several sinall rapids, especially along the upper part, the last a heavy one 200 yards long, where the river flows out of Dyke Lake. There are twelve miles of river between the lakes, and several small streams enter by deep bays on both sides. At the foot of the upper rapid two channels separated by two long islands join as the river issues from Dyke Lake. 
The shores along the river are low and well wooded, and the general flatness of the surrounding country is broken by a few short rocky ridges of irregular outline on both sides.

Entering Dyke Iake by the right-hand channel, a bay about one Dyke Lake mile wide and four miles long is ascenderl to the end of the large island that extends from Birch Lake. The bay is walled in between steep rocky ridges that rise from 300 to 500 feet above the surface. The ridge on the north side terminates abruptly in a sharp puinted hill 490 feet high and cut transversely to the ridge by a great fault, and on this account called Fault Hill. The southern rirge is wooded, the northern one is mostly burnt. The lower flanks of Fault Hill are covered with groves of white and bleck spruce for 300 feet up; above this, only willows and alders grow to near thi summit, where moss alone partly covers the surface. The trees, as the river is ascended, again become small, and, although large white spruce trees are met with on the lower flanks of the hills, they are stunted in height, and thick branches grow close to the ground, forming great knots in the trunk and rendering the wood practically valueless. Poplar is not seen above Birch Lake.

The only way in which an idea of the extent and shape of these Countryabout irregular lakes along the river can be obtained, is by climbing the hills. For this reason Fault Hill was ascended, and from its summit Dyke Lake was seen stretching away far to the north-west. The southern channel extends into a deep bay behind two large islands on the south side. These islands are separated by a narrow channel a short distance above Fault Hill, and from there the upper island continues five miles with a channel nearly half a mile wide, dividing it from a point of the mainland. Looking back wards, the two northern channels, as well as the one ascended, can be traced to Birch Lake. They are all dottel with islands, and the darker water in several places indicates short stretches of rapids.

The bay on the north side of Fault Hill, is much deeper and wider than that on the south side, and extends seven miles eastward. Its surface is covered with numerous islands, very irregular in shape, and apparently representing ridges of drift, the lower portions of which are submerged. Abreast of Fault Hill, the lake is nearly twelve miles wide, but no idea of its size can be obtained on its surface owing to the number of islands. Westward, the lake gradually narrows, and two large islands almost separate the northern side from the main body. Eiglit miles further up, the large islands terminate, and the lake narrows to about two miles. 
The country about this lake is much rougher than any previously passed through and the north side of the lake is bou ded by a continuous ridge that rises from 300 to 500 feet. The larger is!ands are liigh and rocky, and consists of broken ridges. Along the south shore, there is an interval of low land extending to within a short distance west of Fault Hill, where a wide ridge commences and extends westward several miles. This is probably one of the highest points in this region; the main hill rises far above the surrounding ridges and the upper half appears quite barren.

Entrance to Lake Petit. sikapau.

Lake Petitsikapau.

The lower land to the south is covered with large lakes, and the horizon is bounded by a long, unbroken ridge. From the narrows the lake continues nortll-west for nine miles to the head of the north bay, were a short, deep, rocky narrow about two hundred yards wide divides it from Lake Petitsikapau. A high rocky ridge bounds the north side of the lake along this part, with an interval of swamp between it and the water, terminating in a low muddy shore. The high land on the south side ends about three miles up, and is replaced by a flat swamp, thickly covered with black spruce and larch. The trees, on the slopes of the northern ridge are larger, and many stout, knotted white spruce are seen on the lower flanks more than two feet in diameter at three feet from the ground. The main river enters with a short rapid on the south side near the hend of the lake. At the time this place was reached, the water in Lake Petitsikapau was very high, and a large volume was passing through the deep outlet, which was mistaken for the main river. In consequence, a week was spent carefully examining the western and worthern shores of that lake, in search of a large river flowing into it.

Lake Petitsikapau (or Willow-fringed Lake) is the largest body of water in this part of the country. It fills a wide, shallow valley between sharp ridges of rocky hills similar to those already described. Minor ridges cut its ends into a number of deep bays and give to it a very irregular outline. Almost everywhere, the shores are low and swampy and bordered with willows. The greatest length is twenty-five miles from south-east to north-west, and its widest part measures eight miles across. The north-west end is divided into four narrow bays, of which the northern one is the longest. To the southward there are only two bays, the most southern of which is from two to three miles wide, and extends south-enst over ten iniles, with only a narrow neck of land between it and Dyke Lake. The northern end of the lake is covered with numerous low islands of limestone and shale ; these islands are generally long and narrow, running parallel to the strike of the rocks. The water between the islands is very ${ }^{\circ}$ inlow, and 
in many places difficulty is experienced in finding a passage for light Shallow canoes. The southern portion is comparatively free of islands, and water. those found there consist of drift and are somewhat higher than those of limestone and shale. The whois lake is very shallow, and in its widest part, where islands are absent, it was found not to exceed ten feet in depth. Snaall streams flow into the heads of all the northern bays, and from the ridges these are seen to drain chains of small lakes in a wide valley that extends many miles beyond the head of the lake, where the waters of Fanilton River interlock with those of a branch of the Koksoak River llowing into Ungava Bay. The largest stream entering the lake flows through a chain of lakes te sic eastward and empties into the north-east bay. A rocky ridge from 200 to 300 feet high and less than a half mile wide, extends along the north shore westward of this stream, and divides Petitsikapau from a deep narrow bay of Lake Attikanagen or Deer-spear Lake, at Head-waters the head of the George River, which also empties into Tngava Bay. of Gorge This bay runs nortl-west some eight miles, and joins the main body of the lake, which, from the crest of the ridge, is seen stretching awny several miles in that direction; it then bends eastward, where it disappenrs behind a high ridge. A deep cut in the horizon-line to the east shows where the ontlet of the lake passes between the hills.

Lake Petitsikapau is on che edge of the barren grounds. The trees still grow in the valleys and on the lower hillsides, but the upper parts of the hills are barren. Northward a succession of high, harren ridges are sean, with an occasional glimpse of a lake, or of a valley wouded with small spruce and larch trees. Total barrens do not occur in Labrador until Ungava Bay is reached, as trees always grow in the river-valleys to the south of it, although the uplands beyond Petitsikapan are covered only with willows and arctic shrubbery.

For many years the Hudson's Bay Conmany had a post called Fort Fort Nas. Nascaupee on the second northern L'ay of Petitsikapau. This post was cauree. established about the time of $\mathrm{NeL}$ an's journeys from Ungava to Hamilton Inlet, in or about the year 1841, and it is mentioned by W. H. A. Davies in an article published in 1843, as having then been lately established.* This post was erected for trade with the Nascaupee Indians of the interior, and was quite successful until after the second establishment of Fort Chimo in 1866, when the Indians began to clesert it; those from the north going to Fort Chimo, while the sonthern Indians truded at Mingan or Seven Islands, on the Gulf of St. Lawrence, or at Northwest River-all of them preferring to undertake the long

"Trans. Lit. and Hist. Soc. Quebec, vol. IV., part I., p. 74. 
arduous journey to and from the const, where they eould obtain better prices for their furs, and purchase provisions and other necessities at a nunch $_{i}$ cheaper inte than at the interior post, where the cost of transport and maintenance added several hundred per eent to the original cost of the goods. The post was aecordingly abandoned abov c 1873, and now the only trading posts of the interior are thos's situated at Niehieun and $\mathrm{M}$ istassini. Ruim of the The uins of Fort Naseanee stand in a small elcaring, elose to the
fort. slore of the lake, and only a short distanco abov's higl-water mark. The houses were built of small, squared logs, with board roofs. When visited, the dwelling-house was in a fair state of repair, with the window saslies and some of the glass still in place. The doors and movables inside had been broken up and used for firewood by Indians; the roof was nearly unbroken, and lenked only in a few plaees. This building is about twelve by eighteen feet, and has a low room under the attie roof above. Adjoining the main building on each side are two smaller buildings, evidently used for a kitchen and store; the roofs of both have fallen in. Traces about twenty yards to the east of these ruins, probably represent the remains of some ontbuilding. Ahout fifty yards behind, the powder-house eovered with eurth was seen, with broken roof and partly filled up with earth. Adjoining this is "s s'nall burying place with a large wooden eross in its eentre, but without any marks on the graves, which are probably those of Indians. In the attie a fragment of "The Albion," of Mareh 7 th, 1845, was found. Close to the house were several patehes of rhubarh eighteen inches bigh, while a number of introdueed plants stil! !nurish in the old door-yard.

River alwove Dyke Lake.

Is previously ste+ $\mathrm{d}$, the main river flows into Dyke Iake, from the sourh, elose to its north-wesc end. At its entranee the river is obstructed by a number of small roeky islands and large boulders, between which the strean deseends in $n$ henvy, shallow rapid about 300 yards long. 'The lake above the rapid has the general north-west and south-east trend, and is six miles long and two miles wide at its south end, gradually decreasing to a nile at the othes end. Both sides a re high and rociny. The river flows into the lake from the south almost opposite the natlet. At the entranee a large dyke crosses the stream, forming a number of islunds with heavy rapirls between them; above the rapid is a short streteh of swift current, and a large island of drift divides it into two equal channels each about 300 yards wide, w'ere the river ialls with shallow rapids for a quarter of a mile from Astray Lake, inmediately above. 
Astray Lake, so cnlled from our wanderings in sonrch of the river, Astray Lake. follows the general direction of all the lukes of the vicinity, determined by the course of the rocky ridges. From the head of it's longest northern bay to where the river lenves it, the distance is twenty-five miles, and the south-enstern bay ext.ends some distance beyond. In its wiclest part it is about four miles neross. Two rocky ridges, forming long narrow points, divide the northern half into three deep narrow bays ; the southern end, five miles below the outlet, narı... s to less than two miles, and passes elose to the feot of Red Mountain, the high hill seen from the top of Fuult Hill. Two low ridges of limestone extend down the eentre of the wide purt of the lake, and form chains of rocky islands. The ridges on the south side of the lake are low and broken, and the shore line on that side shows frequent low cliffs of yellowish.white limestone. Quartz Hill is a sharp hill of white quartzite that rises 300 feet above the lake, on the south side, opposite thr outlet. This hill is wooded almost to its summit with white and black spruce trees, but on the summit they do not grow more than six inches high. The trees surrounding the lake are very similar to those seen about Dyke Lake, except that they ure somewhat smaller.

A small branch of the river flows into Astray Lake, twenty-four miles from its north end, coming in with a short, shallow rapid from the next lake, enlled Marble Lake, which is separated from the last only by a narrow ridge of limestone. The other ehannel of the river flows out of a south bay and joins Astray Lake, a few miles to the east of the first.

Marble Lake stretches north-westward from the outlet, and for fonr Marble Lake. miles is more than three miles wide; it then eontracts to about a mile, and becoming shallow, soon shows current, and thus changes into the river. There is a smnll rapid two miles ubove, where $n$ ridge of ciriftcovered islands extencis diagonally out from a long point on the north side causing the stream to How in a narrow channel on the sonth side. The shores of the lake are low, and often composed of ledges of white limestone. The surrounding country is also low, apparently swampy, and well wooded with a thick growth of small spruce and litch.

The river above the narrows continues to flow with a strong eurrent from the north-west for six miles, in $n$ shallow channel over half a mile wide, with low swampy shores. Many sandy shoals obstruct the channel, and huge boulders are seattered everywhere.

The course of the stream now changes to south-west, and in the next six miles is broken by henvy rapids, full of large boulders, as it descends from the next lnke above. Flowing in this direction, it crosses the 
strike of the rock at a right-nngle, and the rapids are formed by the river passing over nearly flut beds of limestone. Two miles above the bend, there is a fall of six feet, where the river drops down over the edge of a thick hed of limestone. The channel nlong this stretch is very irregular in width, nud is often split by lurge islands. The rmpills end in a long narrow lnke trending north-nortli-west from its outlet for several miles to where it appears to end agninst " high rango of hills. The west side of this lake is bounded by a continuous range of shurp, burren hills that extends far soutliward.

M.niluek Lak's.

sliddle lake.

'Th: river now nearly doubles on its former course, and passes direetly from the south through three long narrow lakes, ealled the Menilıek Lak's, eonnected by short river streteli's. The lower lake is tifteen miles long from its outlet to its head, and it varies from one to two niles in breadth. The rocky ridge nlrearly referred to passes elose nlong the west side, with foot-hills of dhift in muny places rising directly from the water. The country on the enst sicle is low and swampy, and broken only by smoll ridges of drift. An invasion of sandy drift forms two long points extending out from the west side of the lake, contracting the clinnnel anl eausing a vide shallow mpinl neaily lialf in imile long, at the heal of the lake. The next lake is twenty-thres miles long nud its avernge breadth is slightly grenter than the hist. The surrounding country is sfinilur to that last deseribed, being llat eastward and huving tho high, shup runge along the west side. Towmds the upper cull, the course of the lake and that of the hills diverge slightly, so that at its hend the hills are from three to five miles distant, and are lower than to the northward. Twelve miles above the outlet of the lake, a large strean flows through a deep cut in the hills and enters the lake with heavy rapids from the west. Its volume is about equal to one-thirt of the whole river helow.

The midulle lake is separated from the upper hy a stretch of river three miles long. The stren is half a mile wide, and the elunnel is very shallow, with a $\mathrm{n}$ oderate current. The hanks on both sides are formel of drift, and those on the east side are terraced for sixty foct aluse the present level of the lnkes. The upper lake is ten miles long and alout two miles wide. It is very shallow and tilled with islands of drift, two of which are high, with scarpel banks of coarse sand. The ringe of hills on the west sjde is now from tive to ten miles distant, and appears to be gralunlly rlying awing to the southward. In the distance, on the east side, a high range is seen, which is probably the Ice Mountains to the south-west of Sandgirt Lake.

The country on hoth sides of the lake is higher and more broken than previously noted, the ridges of drift being more pronounced. 
This change in the topography is probably dus to the change in the underlying rock, tho strutified Cambrian beds giving place to Archran schiste.

Above the upper lake the character of the river changes completely, Charaeter of and resemble the stretch between Sunclgirt and Birch lnkes, becoming the country narrow und rapid, with an irregular channel filled with many small Mrenihek islands of drift, and with irregular sandy bankw out out of ridges of till. Frequent short rapids, full of boulders, connect longer stretches of swift, unbroken water for the next twenty-four miles, to where the exploration ended at a stnall conical hill close to the east bank. From the summit of this hill looking southward up the valley, the river wits seen to expand into a small lake a fow miles above, and beyond that to again contract as it winds with short bends, from side to side. From information subsequently obtained from Indians acquainted with the part alove, it was learned that it flows out of Ashuanipi Lake some Ashunipi this ty or forty miles south of the farthest point reached, and that its Lake. charucter remuins the same to the ontlet of that luke, with swifter water in a narrow, irregular channel, studded with muny small islands. The region t'irough which it passes is low and broken by rounded hills und ridges of drift that never rise more than 300 feet above the general level.

At th" end of the survey the river is seventy-five yards wide with an average depth of six feet, and the current is about four miles an hour, griving a discharge of nearly $\mathbf{9 0 0 0}$ cubic feet per second.

Lake Ashuanipi, from deecriptions given by the Indians, is situnted close to the watershed dividing the Hami'ton River from the Moisie River. It is upwards of fifty miles long, very irregular in outline, with deep bays, and is partly covered with many islands, some of which are very large. It is not a deep lakc, but its water is very clear and well stocked with tish.

The trees along the river and the Nenihek Lakes are much sinuller Trees. than any previously seen. Blinck spruce forms ninety per cent of the whole, with larch next in abundance, and a few balsam and white bircl. Along the lake shores the trees are very stunted, ard all bent towards the south by the prevailing northerly winds. The stunted growth of this region is accounted for by the large areas of swamp land along both shores, where deep sphagnum covers the wet ground, which below a deptl of eighteen inches from the surface is permanently frozen. The ridge on the west side of the river varies from 300 to 600 feet in height above the water, and is devoid of trees above the level of 200 feet. Much of the lower ground is also treeless, having been 
burnt over by extensive fires at different periods. After such fires the country is eovered only by willows and alders for many yeurs, until the spruce uguin reproduces itself.

\section{Roule to Lake Michiknman.}

Having returned from the upper part of the Ashunnipi River to Sandgirt Lake, an exploration was next male from there to and around Lake Michikammu. A description of this portion of the country is introduced here, beenuse the other route lemls up the Attikonak Brunch to its head, and from there down the Romuine River to the Gulf of St. Lawrence, and it is thotingt udvisable to complete the description of the interior before entering upon that of the southern region.

The route to Michikamau leaves Sandgirt Lake by its northern dischnrge, which is four miles long, over half a mile wide, and is obstructel with largo ishands. The channels are shallow with low shores, und the current is strong, terminnting in a quarter of a mile of heavy rapids,

Iolustick Lakt. where the river empties into Jubstick Lake. This is nnother largo body of water, divided into deep bays by long low points and lnige islands. The surrounding country is nearly flat, nnd broken ouly by small rounded hummocks of rock, that seldoun rise over 100 feet above the general level. There is also a marked absence of the long parallel ridges of drift, and bare rock shows in ahost every elevution, forming the many small islunds scattered over the surface of the lukes. There are two deep bays that extend away from the inlet of the lake. One runs directly south-east, with its outlet close to Flour Lake, into which it discharges by the north channel of the river, as has been already mentioned. The other bay runs due east about eighteen miles, and is divided into two portions by two large islands, that extend from the westward of the inlet to within four miles of the head of this bay. There is also a great bay stretching in $a$ north-west direction from the discharge and ending at the foot of a range of rounded hills some twenty-five miles distant, where a small river flows in, which is used by the Indians as a canoe-route to the caribou grounds on the George River, beyond the north end of Lake Michikamau.

The route to Michikamau follows the east bay, passing along the south shore of the large islands. Four miles from the inlet a narrow is passed, whore the water between the low, rocky islands and shore is so shallow that only with difficulty a ohannel can be found for light canoes between the boulders, which thickly cover the bottom. At the 
narrow, a slight current is apparent flowing toward the west. Beyond the narrow, the route continues up the bay, passing between many rocky islunds for ten miles, to another nut row about fifty yards widle, between the second large island and a long rocky point. Here, the Iniand: current is strong for 200 yaris, when the lake agnin opens out, but is covered lakes. covered with such a multitude of small rocky islunds that no iden of its extent can be obtainer by passing through it. For ten miles the route now follows the south shore, prssing through narrow channels hetween the islets. A number of long, rucky points form deep, narrow bays along shore, and complicate the navigation, no that even an Indian guide is often at fnult ns to the right direction to follow. Two short heavy rapids on a small stremm lead upwarls into another island-covered lake, with even more crooked and narrower chumels through, which the route pusses to a susull bay nenr the eastern end of the lake, tivo miles from its outlot.

A runge of rounded hills from 200 to 400 feet high extends nlong Watershed the north and east sides of the lake. At the hend of the smali lany, Intweres there is a gap in the hills about half a mile wide, wbre at or!inary Northv nt stages of the water a sinall strenm trickles down from the next lake, a mile beyond, through $n$ series of little rocky pools filled with boulders. When tho water is high in Lake Michikamau, which connects with this small lake, n large stream discharges from it through this valloy, thus connecting the hendwaters of the Hamilton River with those of the Northwest River, which flows out of Iake Michikamau on its north side. A portage of $n$ mile und $\mathbf{a}$ balf is here ordinarily made. It crosses n rocky hill on the east side of the valley, and then passes over $\mathbf{n}$ high drift plain to near its upper end, where it terminates on the widebouldery shore of the upper lake. This lnke is very shallow and full of sinnll rocky islands and points, with its shores and bottom deeply covered with boulders. It lies in a continuation of the valley, between low rocky hills. Two miles eastward, a rocky narrow occurs, where the water runs in and out, the direction of the flow being determined by that of the wind. Beyond the narrow, the lake widens to over two miles and extends a few degrees south of east, for eleven miles. A long low point sepnrates this bay from a similar one on the north side. The south side is bounded by low, rounded, locky hills, and the surfice of the lake is strewn with small rocky ivlands, with shallow water between them, where large solitary boulders often rise above the surface. The bay on the north side of the long point, heads nearly opposite the portage, where a small strean enters it from the west. Near the mouth of this streum, the Hudson's Hudson's Bay Bay Company kept a small outpost called Michikamau during the post. 
time that Fort Niscaupee was oecupied. Nothing can be learned about this outpost from the old Hudson's Bay Company journals at Rigolet or Northwest Kiver, beyond the baro facts that a post was maintained there for a number of years, und was finally abandoned from the snme rensons which caused Fort Nascaupee to be given up. This post was not visited, but, from the accounts of the Indians, some of the buildings have been accidentally burnt, and those remaining are in about the same state of decay as Fort Nascaupee.

From the head of the luke, the route turns south-enst for nearly six miles, following down a small river thut flows close along the west side of a rocky ridge-flanked with sandy irift. Tise channel varies from 100 to 200 feet in width, and is bounded on the west side by a long point of sand, broken into narrow islands towards the south. This point and the islands are mere!y a ridge thrown up by the river, between it and a large lake to the westward.

The next change in direction is to cue east, where the river flows first with a strong current between a number of low rocky islands, and then widening gradually passes, for four miles, between ligh banks of drift into Lake Michikımau. The hills, on the west side of the river are rounded and irregular, varying from 50 to 200 feet, and covered thickly with boulders. The east side is from 50 to 100 feet high and flat on the top, with traces of terraces from thirty to fifty feet above the present level of the lake.

\section{Lake Michikamau.}

Lnke Michikamau.
Finer acenery than nkxut Mistassini.
Nichikamau, or the Great Lake of the Indians, is the lurgest in eastern Labrador, being second only in size to Lake Mistassini. Its grentest length from south-enst to north-west is ubout eighty miles, and it is twenty-five miles across in its widest part opposite the discharge. The main body of the lake is sixty niles long, with in long, narrow, unexplored bny extending south-east more than twenty miles, from the soutl-east corner. The widest part of the lake is in the southern third; in the northern purt of the mildlle third, a long point, and a line of large, high islands of eruptive rock, extend far out from the northenst side, and narrow the lake to six miles. Between this point and the north-west end, the average brendth is eight miles. Islands are numerous along the shore and in the southern purt of the lake but elsewlere it is unobstructed. In comparison witls Luke Mistassini, this is a much finer body of water, and its size appears much greater, owing to the absence of long points, and chains of islands. 
d about

Rigolet

$s$ main.

d from

This

some of

ing are

nearly

go west

varies

le by a

. This

- river,

er flows

islands, 1 banks of the

et, and

00 feet

fty feet

gest in

i. Its

miles,

he dis-

long,

miles,

in the

point,

or out

tween

miles.

of the

e Mis-

much

lunds.

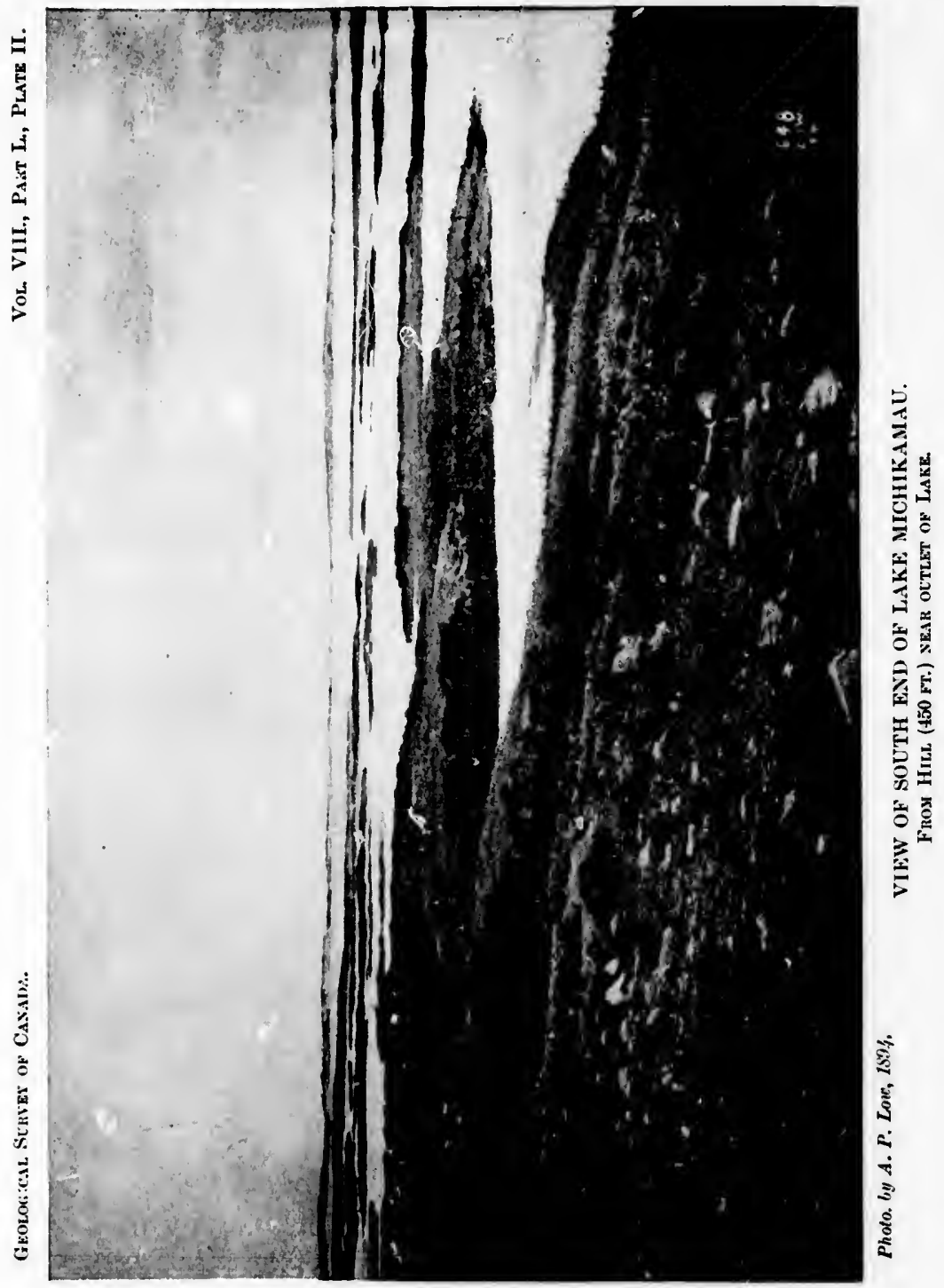


Low. ]

Lake 1 grandev shores c cold, an winter,

On a engnged from th The lak thint en weeks $i$ the car

The Archie bnsin i existed now fo

The above small treeles: shores, clump From nortlı" cession only it merabl North inlet, islands irregul narrov the to on the lake. dark-l, nlso $f$ is qui culmir high, , 
Lake Michikamau is surrounderl by rugged hills which add to the grancieur of the scenery, in marked contrast to the low monotonous shores of Mistassini. The water of the lake is remarkably clear and cold, and according to tlee Indians, who set lines through the ice in winter, the depth is very great.

On account of the henvy sea running during the whole time we were Delays caused engaged in exploring the lake, it was inpossible to make soundings by wind.

from the small canoes, except behind islands und close to the shore. The lake being free from islands, any moderate wind raises such a sea that canoe travel is frequently impossible, and the Indians are often weeks in passing from the dischargo to the north end, on their way to the caribou grounds.

The lake occupies in deep basin surrounded by chains of rounded Archisun hills that rise from 200 to 500 feet above its surface. This basin is very ancient, and like that of Lake Mistassini, must lave existed previous to the deposition of the Cambrian rocks which are now found lying undisturbed in muny places around the lake.

The hills surrounding the lake are wooded for only about 200 feet Character of nbuve the water, their tops being covered with white lichens and the surruumdsmull aretic slurubs. The outer islands and exposec' point: are also treeless, and the trecs growing on the more protected islands and shores, are small black spruce and larch, with only an occisional clump of strnggling whits birch on the lower slopes of the hills. From a high batren hill north of the discharge, the view looking northward beyond the lake is exceedingly desolnte, and shows a succession of low rocky ridges extending to the horizon. Trees grow ouly in smbil patches in the lake-strewn valleys between, und innumerable huge boulder's are scattered indiscriminutely everywhere. Nortliward along the west shore, for seven miles from the inlet, the shores are low and houlder-strewn, with many sunall low islands of drift strung along in a close fringe. The shore-line is irregular, and small ridges of drift form points behind which long, narrow bays run off westward. Some of the islinds are flattened at the top, evidently ly the action of water, and there are sinall terraces on the searped sides up to thirty-tive feet alove the present level of the lake. Beyond this the sluores become ligher, with rounded hills of dark-hrown rock rising in snull hummocks above the drift, and also forming high rocky islands along shore. The country behind is quite rough, rising in irregular hills, from 50 to 250 feet high, and culminating in a sharp cone called Petiscupiskau, more than 350 fect Petiscapiskau. high, which is visible for many miles along the other shore, and fornis Hill. 
an admirnble triangulation point. From Petiscapiskau to the north end of the lake, some six miles, $\therefore$ shores are low and sandy, with boulder-covered points. The land slopes gently up froin the water to an even ridge of drift-covered granite about 300 feet high that extends north-west far beyond the north end of the lake.

The north shore is low and sandy, with shoal water extending far out from it. Many boulders of red granite are scattered about, both jn and out of the water, and are sometimes urrnngel in rows along the shore, by the expansion of the ice in the spring before the waters rise.

A little river enters the north end of the lake, with a small rapid full of large boulders, where the channel is about fifty yards wide and too shallow fol canoes. This is the discharge of Michikamats or

Michikamats

Iake. Little Michikamau Lake, which occupies the northcrn extension of the valley ard is separated from the main body of the lake only by a long, narrow interval of drift. This lake is over twenty-five miles long, and extends north-west to and beyond the ncr?' side of a high range of hills which is seen in the distance to divide the min valley. From the north oud of Niehikamats, thre Fin iges connectin's nurrow lakes lead to a branch of the (reorge Rives, where the Indians of the region assemble in September to spear the caribou, which tizen cross the river in inmense herds in the cour of their annuml migration from the high baren grounds behind Nitin to the wooded region of the interior, where they pass the winter.

The east shore of Michikumau for twenty miles from the north end, is low, with bouldery points and reefs, and without the fringe of islands. A sharp rocky ridge 30 J feet high runs parallel to the shore, and about six miles back from it. The interval between the water and the hills is occupied by small lukes and swanps that lie between low ridges of drift.

Twen' $y$ miles up, the highlands come out on the shore of the lake; al $\div$, $m$ there to the outlet, or for the next thirty miles, the shores are high and rocky, with deep water close in, and only a few small rocky islands along shore. The country behind is exceedingly loroken and rough, with bare hills of dark-brown rock, rising in irregular, sharp bossis from 50 to 300 feet above the surface of the lake. Along the lake southward, the gabbro rocks, which form these broken hills, are replaced by granite near the discharge, and then the country becomes more regular, although still very hilly.

Country to the From the summit of a barren granite hill 400 feet high, close by, Michiskannu. the discharge or Northwest River is seen to leave the lake ber ween 
a number of large, flat-topped islands of drift about thirty feot high, that extend outwards from the shore some four miles, and along it for six miles. A long, low point of drift, passing into a ridge, separstes the river from the southern part of the lake, and the river is seen extending eastward through a succession of lake-expansions, until it passes behind and is hidden by roeky ridges in that direction. Another chain of lakes extends northward from the river and pnsses close to the base of a ligh range on the horizon. By these lakes a second route lends to the caribou grounds, which is used by the Indians when they want to proceed there direct, without the delay usually caused by adverse winds on Michiknnau and Michikamats. The river flowing into the Atlantic near Davis Inlet, heads in the high range to the north, and a winter-route from the George River to the const follows its course closely. Owing to many rapids and falls, entailing several long portages, this stream is never used as a eanoe-route by the Indians.

From the discharge to the south-east enc' of the main body of the Southern lake, some ten miles, the shores are low and sandy, with boulder-shrres. eovered points and much swampy land behind. There is a deep narrow bay that extends south-east from this corner, where it passes away between rounded, rocky ridges, running parallel to its course. Its entrance is nearly closed by small, low islands; its upper end was not explored, but it is said to be more than twenty-five miles long, with a small river falling in at its head.

The south end of the lnke is shallow and is dotted with many small islands of granite. The shore is very irregular and often rocky, and the countily behind is broken by severnl ridges from 200 to 300 feet high. There is another deep bay on the south side, where a couple of small streams discharge.

The country along the west side is broken by low ridges, with a wide interval of swanpy land along the shore. The coast-line is indented by deep bays, between wide swampy points, fringed with boulders. From the south end to within five miles of the inlet, there is a wide fringe of large islands of sandy drift, that rise only a few feet above the water.

\section{Attikonak Branch.}

The northern channel of the Attikonak Branch flows into Sandgirt Attikonak Lake on its south side. It is ascended from the lake in an east-south. River. east direction three miles, to where it is broken by a henvy rapid nearly a mile long, with the channel about 100 yards wide, choked with 
large boulders. A portage of a quarter of a mile, neross $n$ boulder $\cdot$ strewn point, ends in a small bay of a lake-expansion ubove the rupid. From the head of the rapid the river widens to netrly a mile, and for tho next three miles flows from south-south-enst. Beyond this course the direction ehanges to north-west, and eontinues so for tive miles, in a narrow, irregular ehannel, o'structed by numerous islanils, and bounded by low, roeky shores in many places, to where a small brunch from the base of the Ice Mountuins joins the main streaun. A eluin of small lukes is now entered, eonneeted by short rajids. Tlie general course of the route through these lakes and in larger lake above them is south-south-eist, ; the lower lakes are four miles long, while the large one, called Ginbbro Lake, is seven miles from outlet to intet, with a long bay stretehing towards the south-cast. Another nurrow one Ossokmanuan mile long, with a slight eurrent, joins Gabbro und Ossokmunuan lakes. Liske. The latter is a narrow body of water more than forty miles long, and lying nearly east-south-enst. From its northern outlet it trends direetly south for eight miles, and in this portion varies from two to four niles in width, being dotted by many small rocky islands, and surrounded. by low rounded ridges of drifteovered roeky hills, with roek showing below the drift in many places along the shore. Another bay stretehing away more than twenty mil's to the north-west now joins the main body. Like the first it is full of islands, muny of them composed of conrse drift. The soutl side of this bny is bounded by a ridge 300 feet high, and at its head a small branch falls in, which drains $n$ number of lakes to the soutli-westward and forms a ennoeroute to Lake Ashuanipi, on the way to the Moisie River. From the junetion of the two hays, the main body of the lake extends south-east twenty miles, and then south-sonth-east fourteen miles. Five miles up the first eourse, the foot of one of two high, roeky, large islands is reached. This island is six miles, and the other ten miles long, and they practieally divide this portion of the lake in two. The part on the south side of the islauds averuges two miles across, the northern channel being somewhat narrower. On the north side near the liead of

Valley River. the upper island a branch ealled Valley River tlows out. This stream is somewhat larger than the northern outlet, and constitutes the river which at present flows town the Hamilton River valley alove its junetion with Bodwoin Canon. Aceording to our guide, aftcr passing through two lakes, together about twenty miles long and eouneeted by rapids, it begins to fall anpicily in it succession of low ehutes. Alout these ehutes the valley is still wide, with gently sloping walls and not like the eañon on the main river. The guide had never visited the river below the chutes, but lad heard that there was a high fall on it, some fifteen or twenty miles ubove the place at whieh the muin body 
of the Hamilton River enters the valley at the mouth of Bodwoin Cañon.

Besides the large islands already mentioned, there are only a few small ones, formed of drift, in the southern half of the lake. The water is elear, but has a brownish tingo and is never very deep. A continuation of the high ridge on the west side of the north-west bay runs on southward along the west shore of the main body, but gradually dies out townrds the southern end. From the lake the land rises slowly upwurds to this ridge, leaving a wide interval of lat land and low shores along this portion. On the north-east side the country is lower, and is only broken by a few rounded rocky ridges that have recently been burnt ovi r. The tiees about the lake are sinall, and are ehiefly Trees. black spruee : ith 'areh and balsam fir, but no white spruce. Balsam poplar and no mitain ash are seen growing in small straggling clumps on several of the low points on the west shore.

The river enters the lake on the west side, some ten miles from its south end, where it narrows to less than two miles. Its volume is ejnsiderably greater than the channel ascended to Ossokmanuan Lake, being half as large again as the Ashuanipi Branch at the end of $\therefore$, survey, and flows swiftly from the south in a shallow ehannel from 400 to 1200 yards wide, with low banks and frequent hunnocks of gneiss for eight miles, to where it leaves Lake Panehiamitkats. The country on both sides of the river is slightly higher than about the lake below, and mueh fine drift is seen on the islands and shores arranged in long parallel ridges from thirty to one hundred feet high, running parallel to the glacial strise or a little east of south.

Lake Panchiamitkats is about twelve miles long and averages two Panchianit. miles in width, with its longer axis running due north-and-south. It is dotted with a few small islands, and has low drift shores. There is a prominent rounded hill on the west side just beyond the entranee of the river, five miles above the outlet. Another hill rises from the east shore opposite the inlet; the remainder of the country is covered with low ridges that run parallel to the lake.

The river above its entranee to this lake, flows frcm the west for a mile and then from the south, and is separated from the southern end of the lake by a narrow ridge only. It continues from the south for sixteen miles, to wliere it flows out of Lake Attikonak. Its ehannel is from 200 to 600 yards wide, obstrueted hy small rocky islands, while its shores present nany roeky points. The current everywl. re is strong, and the stream is frequently broken into short rapicls between the many small roeky islands. Ten miles up, where 
the river passes nver rocky ledges, there is a clsute of four feet, followed by a short heavy rapid that necessitates n portage. Above the chute the current is slack and the river nearly half a mile wille, with :nw sundy shores, to within two miles of the upper lake, where there at, two short rapids, the upper of which is wide and very slu:llow, as the river issues from Lake $\Lambda$ ttikonnk. The countly surrounding this stretch of river continues low, with long, rounded ridges from fifty to one hundred feet high. The timber is similar in kind but perliaps slightly larger than the last descriled.

Lake Attikonak.

The enst s!ore of Lake Attikonak was followed in a direetion a few degrees enst of south for thirty-eight miles, to the hend of $1 \mathrm{~s}$ south-east bay. On account of the great number of islands that ever.' shere brenk its surface, no idea of its shape or size can be obtnined without a complete exploration of its shore-line, which tnsk, owing to the many deep bays in the lake, would have required more time than coukl bo given to it. From a number of long leads scen between the islands, tho lake must be at least twenty miles wide in places, and, according to our guide, its south end is considerably beyoul the hend of the bay where the route leaves it. A large strean flows in at the south end, which rises in lakes to the southl-west of Attikonnk, near the hend waters of the Magpie River, flowing into the St. Lawrence; and it is used as an alternative route to and from the const by the Indians Large islands, of the interior. Many of the islands in Lake Attikonak are large und high, one of them rising into a rounded hill of 300 feet, others seem to be formed wholly of tine sundy irift, with irregular outlines, and scarped banks up to one hundred feet in height. Very little rock is seen axcept in the south-east b:y ; elsewhere the shores are genernlly sandy, with low, boulder-strewn points. The water of the lake is clear, with a brownish colour, and does not appear to be very deep. The eastern side is bounded by low ridges of drift, with a range of hills from 200 to 300 feet high some few miles behind. At the south end of the lake, thcre is a sharp rugged range of hills, extending away westward, probably more than 400 feet high. 'The trees continue to increase slightly in sizo, black spruce predominating, but associated with balsam tir, larch and white birch, the last often occurring on the islands and points ir. large clumps with many trees up to ten inches in diameter. Near the south end of the lake, two small clumps of dwarfed aspen were seen, the first noi cai since the Grand Falls were passed.

From the outlet, the lake lies due south for twelve miles and is from one to three miles wide, with several deep bays running off on both sides. A large strearn falls into a bay on the east side, immediately 
above the rapid, while another enters from the west three iniles farther south. Above this the course changes to south-south-west, and continues in that direction through a labyrintl of islunds for sixteen miles to a short narrow lending into the south-east bay, which was followed for twolve miles, to its hend. This bay gradunlly narrowa from two miles to less than a half mile at its head, where a small strenm flows $i_{n}$ with a short, steep rapid. "'it: $\therefore$ nres and islands of the lower half of the bay are formed of sund ha : alders, while along the upper half they are steep and rock, wit: o country behind higher and more rugged witl very litfle: dis:, the Lare rock rising everywhere in small knolls. Here the ivas by ome much smaller and are wholly black spruce and larch.

The routo passes up $\mathrm{tl}_{\mathrm{a}}, \mathrm{al}$ ? stream lnst mentioned, $\mathrm{n}$ short distance Portage to to a very narrow shallow iake at its head. A portage of two miles, Romain. over and between a number of small rocky hills with swamps between then, joins the last lake with a little strenm emptying into the Romaine River. 'The country about the portage has been recently burnt over, and the standing bluckened trunks of the small spruce give a sort of hairy nppearnace to the otherwise bare rocky hills, from which all the vegetable soil has been removed, and do not add to the beauty of the scenery, which is very rugged and desolate.

\section{Romaine River.}

It is only a quarter of a mile by the little stream from the end of Uprer the portage to the Romaine River. The latter where joined River: varies from fifty to one hundred yards in wilth, and for two miles passes between low banks, broken by rocky knolls. At the end of this distance ther, is a short heavy rapid, where the rivel passes over a rocky ledge between small islands. A portage of fifty yards is necessary here. Below this, for six niles to the upper Burnt Lake, the banks are low and sundy and often overgrown witl willows and alders. The river winds backwards and forwards with a moderatecurrent, and has fornied a delta of low sandy islands where it enters the lake. On the eac side there is a large lake that is separated from the river only hy a varrow low point of sand. This lake has a short discharge wi,ich joir.s the main stream three miles below the rapids. The country surreanding the river is slightly rolling on the west side, with rocky hills from 50 to 200 feet high. The water of the river is darkbrowi in colo"r, and carries more suspended matter than the rivers of the eastern watershed. 
Healwaterw. According to the guide, nbout ten miles alove the place at which the portage-route joins it, the Rommine River issues from n narrow lake nearly twenty miles long, that extends north-eastwark, ant is called Tishinakanınu Lake.

Beyond the hend of this lake the river is very small, and soon breaks up into little branches, the discharges of small lakes near the hend. wnter: of the Silizaheth and Minipi branches of the Humilton lRiver, and also near the sourees of the Natishyuan River, that flows southwari into the St. Lawrence. Portage-routes eonneet the heuds of all these strenins.

'T'he Burut Salken.

Character of the river leelow Burnt Lakes.
Upper Burnt Lake is twenty miles long and vurjes from one to four miles in wilth. From its henl, for six miles, its course is enst-south. east, and then changes to sourli-south-enst to the lower enu. Twelve miles from the upper end, a deep bay extemis souti-west for live miles. The middle portion of the lake is for several miles grently obstrueted hy long islands of drift. The country surrounling the "Ip es part is low, with long sloping hills quite different from the rounded knoils previously passed; for there is a change in the rocks of which they are composed, the formur leing grunite, the latter gabbro. Townds the soutlı end, the country becones higher and rougher, with the ridges closer together. Small black spruce und larch predominute, with some white bireh on the islands.

A short rupil at the south end of the lake, joins it wilh the second Burnt Lake, which is four miles long, with a deep bay on the west side. Another short rapid and a mile of river connects this with the third Burnt Lake, which continues southward for two miles, and then turns ubruptly north-west for five miles to another short henvy ripid that tlows into the lowest Burnt Lake, the south shore of which was followed westward two miles to its outlet. A long bay extends morthward several miles, and a portage at its head connects with the south bay of the upper lake. The country alout the lower lnkes is quite rough, with sharp ridges of rocky lills rising from 200 to 400 feet directly from the water. The forest about all tlipse lakes has been devastuted by a grent fire some ten years ago, and now only small patclies of green woods are seen in swamps and in spots along the banks.

As it passes out of the last Burnt Lake, the river falls twenty-five feet $i_{n}$ less than a quarter of a mile, in a heavy rupid, over luge bouklers and n few ledges of rock. For seventeen miles from the lake, to where a western branch joins, the general course of the strenm is due south. Half a mile below the first rapid, the river ugain falls twenty feet in one 
hundred yards, over masses of huge boulders. From here it wimls to and fru, with $n$ strong current, betwen steep banks of stratified sand from ton to fifty feet ligh, in a valley from two to four miles wirle, bounded on butli si es by strep, rocky hills that rise from $\$ 00$ to 500 feet ubwe it. About seven miles above the forks, the river is broken by small rapids at intervals for nearly four miles; here the valley is mueh unrower and the semperd lanks are ocensionally 150 feet high, with rock coming out from benentl. The west brauch hus about half the volume of the mnin strem, and enters it with a heavy rapid from a narrow valley hetween the hills. The trees are everywhere lurnt, except in a fow patches liere and there, along the river-banks. They ure somewhat larger, and white spruce grovs on the points and islands. Distinct teriaces are seen at intervals, with elevations of 10, 20, 50 Terraed drift and 60 feet alwove the present river-level, eut out of strntified sund with a large almixture of elay.

Below the forks, the river is from 100 to 300 yards wide, aud Hows swiftly in a slanllow ehnunel with a sancly lottom and steep banks of the sume material from ten to thirty feet hish. For eight miles the general course is south.enst; it then turus south. and flows in that direction sixtern uiles. At the bend there are on the west side several sharp, irregular hills of drift which extend one mile to the foot of the steep rocky hills. One of these hills cut into by the river, sliows the sand and gravel to be false-bedderl, and, in other places along the river, the beiding of the sands is not horizontal. These hills are thickly strewn with boulders, which do not appenr to be seat tered through the mass, but only over the upper surface, leading to the belief that the deposition and stratification of the drift took place in ice-wnter flowing under the glacier, ant that the boulders on the surface wete left there by the ice on its dissolution.

Below the bend, the valley narrows gradunliy for four miles, to two Character of chutes, where it is less than $n$ mile acoss, and is fillerl with slinrp the valley. hummorks of drift from 50 to 150 feet high, covered with boulders. At the upper ehute, the river passes along the base of a granite hill that rises slieer for 500 feet. This fall has a drop of four feet, followed immediately by another of six feet, enting in tifty ynrds of henvy rnpirls, where the descent is twenty feet. Fifty ynrds below is the second chute, twenty feet high, followed by heary rapids for three miles. The banks imuetiately below this chute are from 50 to 100 feet high, and sections sliow them to be composed of re-arranged till, with false bedding; the angle is so high that in places it is impossible to walk along the foot of the cliffs, owing to the displacement and 
slipping of the sand along the beddiug planes. Terraces up to sixty feat are numerous along the sides of the valley.

Below the rapid, for nine iniles, to the uext beul, the current gradually slnckens, until it flows along with un even rate of ubout threo miles an hour. The chnnnel widens from 50 to 200 yards, and the valley also opens to nenrly two miles, with sharp rocky hills bounding it on both sides, those to the west presenting high eliff-fnces. The sharp hummocks of till grudually die out, lenving low mud aluost that stretches to the foot of the hills on either side. The country is wholly lurnt. The next bend is tos the south-west for ten miles, am for that distance the river preserves the same charneter us above, but is slightly wider, being now about $n$ quarter of " inile neross. Six miles from the bend, a sunall brunch, forty yarils wide, cones in from

Hixtrinive. lurut uregn.

Ditticult jor. take-routte to St. Jilin Kivir.

Trilutary of the Rombine Kivine. the west. The old burnt woods end nenr the bend, but a tire of tho present sensol (1894) hus passed over all the remaining green woods below, and has prinetically destroyed all the forest along the river.

The river now turns south fur wix miles to where the portuge-route to the St. John River lenves it by a snull western trilutary. The ehannel along this stretch varies from a quarter of a mile to half a mile across; the river is very shallow and grently olstructed by large sundy shoals. The valley is more than two miles wirle, and the hills bounding it rise sharply from 600 to 800 feet nlove it. A sinall herunch joins from the west two miles below the lnst bend. Below the plnee at which the portage-route lenves it, the river tlows south-enst for four or five miles, in a wide shallow channel that slowly contracts as the current increases, and finally brenks into lenvy rapids where the river passes into n narrow eut between steep high hills. Nothing is known of the river for over fifty miles below this point, except that it is quite impussable for canoes, probably on account of long rapicls with perpenclicular rocky walls, where portages are impossible. Nothing but the alssolute impossibility of passing up and down this part of the river, would induce the Indians to make use of the present portage-route between the Romaine :ad St. Jolın rivers, which is the longest and worst of those known to the writer anywhere in north-enstern Cunah. Careful inquiries from a score of Indians met coming inland, nfforded no information coneerning tlis part of the river, which lons never leen descenderl by any one so fur as known.

\section{P'ortage-route between the Romaine and St. John Rivers.}

The small branch previously mentioned, was ascended from the Romaine haif a nile, to a portage three quarters of a mile long, past heavy shallow rapids. The portage passes along the west side, through 
burnt wools and over snnily hills that rise from 50 to 100 feet uhove the river on the slopes of the rocky hills bounding the uarrow valley. lioyond this the strenm is followed for a quarter of it mile to a portage of the same length; after which it is ascendel for hulf $n$ uile to $n$ portuge of une inile, fullowed by a stretch of river one mile loug, ubove which the strenn divides. The valley of the south liraneh is followed with a lialf mile portage, to a' small lake two miles and a half long, from which $n$ portage of a mile anil a half lends over the heightof-Janil between the Romaine and St. John rivers. The branch, as will be seen from the alove deseription, is full of long, sliallow rapidy, und flows through a narrow valley between steep rocky hills, from 200 to 300 feet high, frontel by lower hills of sundy drift, over which the portages pass. 'The hills along the small lake apo somewhat higher and more rugged. The country tinvelled through is mostly burnt und the standing trees ure sinall.

Beyonl the height-of-luml, the route jnsses for twe miles and a half 'Prihutariem of through two little lakes connected by a short pertage. From the the St. John dischurge of the second lake, a pertage of three-quarters of a nile lends up hill to a small pond, and then down hill across the diseharge of the last lake to the foot of $"$ high fall. Next follows a short stretch of river, with a three-ruanters of a mile pertnge pust henvy rupids, elosely followed by three short portnges, past chutes. These portages, though short, are excetelingly bad, going straight up anil down the rocky walls of a narrow gorge, over great blocks of anorthosite. The lust ends in a narrow lake hemined in by rocky walls that rise sheer from 500 to 800 feet nlove the water, and often present over-langing cliff, the sides being purtly wooled with small spruee and birch that form a pleasing contrast to the bare rock elsew!lice. In muny places great hlocks have been detached from the eliffs and are heaped up at their basc. A number of small streans fall perpendicularly over the cliffs.

At its clischarge, the river falls seventy left in as many yards, through a narrow pass partly fillerl wilh huge angular blocks. The portige is along the side of the cliff, often strnight up and down, over blocks and through the water, the whele making th." worst possible combination of obstacles. Below the prortuge, the river ; followed for a mile and a half to its junction with a largen strean from the west. Just below the last-mentioned purtage $a$ large strean falls in from the east with two chutes over 300 feet high. Jower lown, a smaller strean comes in on the same side with a higher fall, which shows that the valley is much beiow the general level of the surrounding country. 
The next portuge lenves the river n short distance ubove the westeru brunch, and in three-punters of a mile ascendis over 300 feet, anding just alove " high elunte on the west hranch, where it fulls, down n nurrew gorge, to join the other branch lelow. This streun is then ascomderl for four miles, with two short portages past rnpils on the way, ('liff Lake. before rending Cliff Lake, which is eight miles long and from a lualf to ono mile wide. Tho scenery ahout this lake is very striking. Both sicles now formed of vertical eliffs, often rising sheer from 500 to 600 foret ubove the water and terminating, in the higher poinis, in bare, rocky knolls, without in purticle of soil. In muny places glent missess of roek luve broken nway, und are new piled up in confused nusses that extend far out inte the lake. At every depression in the walls of the valley, little strenus fall into the linke nut uro fringed loy smatl treess of sprence and birch, which ulso grow along the edges of the take and in rocky crevices up the sicles of the cliffs.

'l'he sumall stream that llow's in at the head of the lako is aseenterl for thre miles, through two small lake-expmesions, to n pertage of one mile ending in a very small lake nt its heml. 'The mext purtage is two miles nut n half long, and follows a valley between

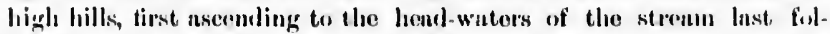
lowed and then dewn anothey small brosk flowing in the opposite direction. 'This purtuge, bessiles being loug, is very rough, lesuling corer broken rock and through swmmps. It ruds in a small lake out of which a little river tifty feret wide issues and flows somtliwarl with a winding conrse and strong eurent, in a deep valky nbout one milo wide. Its bunks wo low nuel gemernlly samely, mal the valley is

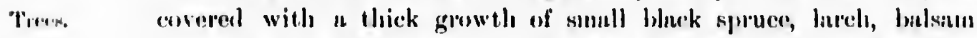
fir und whito birel, somewhe lurger than any previonsly soen on the ronte from the Remnine River, lout still too small to las of any commereinl value. This littlo river was deseconded for eleven miles to where it is joined hy a sunall western branch, which was aserended for one mile, llurough a shallow lake. Thenee a short jortuge lemls to another rery small lake on the susuo stronm, followed by still another portage of a third of $n$ mile into $n$ thire! small lake at tho liest of the strenm.

A portnge two-thirds of a mile long next lends up hill wo nowther sunnll lake, from which a portage of three miles followe the strenu issuing from it, and descents 600 foet to the next lake lelow. There is here $n$ generol fall in the surface of the eountry and $n$ chunge in the outline of the hills, as the route passes from the rugged unothesite aren, wath its high knoh-like hills, to the lowere and more rolling cuuntry underlnin by gueiss. 
The lake at the foot of the portage is a little over two miles long, P'ortnges to

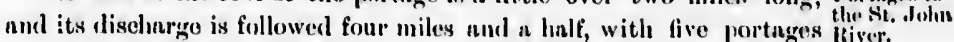
past shallow mpiils. A portage of a half mile pusses up from the strenm over a l.ill 300 feot high to a lake 100 feot ubwo it. 'Tlis lake and its ontlet aro followed three miles, with two short portuges on tho way, to the last portage to the St. John River, which buves the small stream ancl patsse's down a steep gully cut out of drift for uhout one mile, where it descends 365 feet to the level of tho st. Jolun liver

The total number of portages from the limunine to the St. John is thirty-one, ant their combined length aggregates nineteon miles unl in hulf.

\section{st, dolin liwer.}

The st. Juhn liver, where the portingeroute joins it, is about 100 st.duhn ynals wide and pursues a winding contse in " valloy nlent ono milo liviver. wide, boumded hy steep hills from 290 to 500 fewt. highls.

'Plore is a great aceumulation of drift in the valloy, oust of which the shallow channel of the streim is eut. The banks are mestly low where the river arosses the valley, and are light only at the hencis, where seetions from ten to sixty fout deep show stratified satuls overlying cliay.

$\Lambda$ few mil s alowe the prortage, the river is broken by heasy mids

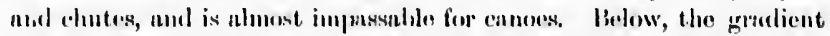
of the valley is sterply, and the river in corsenguence has a strong enrent, esprecially at the lorols, where it geneonlly halls with short rupiels

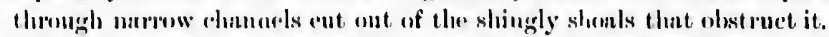

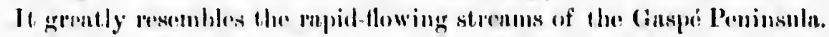

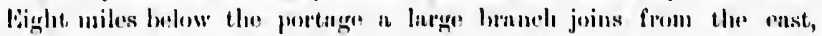
the herul-waters of which form the varinus st reans of the portage-route alrendy described. Below this branch the elanmel widens smonewhat

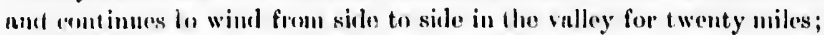
the hil's then close in, and the river deseends a marrew gorge, with a honvy mpoid conding in a fall of twesty foot.

Ilow trees in the valley show a marked improvement beth in sizo and Trens. variety. White spruce fifty feet tall and from twelve to einliteen inclues in diancter is plentiful, along with largen hlack spruce, billsum lir, lateh, white birch, hals:um poplar and aspen. Tle sides of the valley are more than half hurnt.

The portage prest the chute is narly a milo long aud passes along the nlmost perpendiculat side of the valley some 300 freet above the strenm. The ascent and descent at both sides is so steep that the Indians are 
forced to cut steps out of the soil in order to pass over with londs. In the mirille it is elose to the rocky wrll, and tha road has been made oy plncing logs nlong nurrow parts, whieh almost overhang the boiling strenm fur below.

Sinluon Branch.

$\Lambda$ mile below this portag, the Salmon Brnneh joins from the west. It has n deep valley like the main strenm and is considernbly smaller. About a mile below this branch there is a salmon fishing camp, with a fine large hou se situated on $n$ wide bank nt the mouth of a small strenm, the resort of sportsmen during the summer.

From the ehute the generul course of the river-valloy is nlmost south for twenty-five miles, to the eonst. The valley is nurrower than above, and fur ten miles does not exceel half a mile, with walls of anorthosite roek rising in neurly perpendicuhr eliffs from 300 to 600 feet nbove the water. $A s$ the eoast is approncherl, the valley widens and the hills become lower, so that a short distnnee below Chambers River, or ten miles from the meuth, the roeky hills give plice to hanks of stratified chy and sand thut grudually decrense in height down to the sen.

The country surrounding the river has heen over three.quarters burnt, and the remmining forest is very similar to that alrealy described.

The river from the chute to its mouth varies from 200 to 400 yurds in width. It is quite shallow und has a very mpisl eurrent, with many short rupids, as it winds from side to side in 'se valley. The limit of ticle is eight miles and a hif nhove its mouth.

\section{Mrenimagan River.}

P'oxition of che month.

The Manieungan River flows into the St. Lawreneo abcut two hundred ind forty miles lelow Quebee. Within ten miles of their mouths, the Manicungan and Outareles rivers are separited only hy a high s wal pluin, nhout two miles neruss. Above und below this plices, their eourses diverge, so chat their mouths ure fifteen miles apart, und the land between forms a brond peninsuln eomposed of strutified elny and sand, evidently brought down by the rivers. The ehannels, thus diverted, instend of passing out into the Gulf of St. Lawrence, ling the shore for several iniles with wicle sandy shonls outside. The Outardes water flows westwarl, an' that of the Matnieungan River towards the enst. Owing to the ehannels being in shore and to their broadening as they lenve the mouths of the rivers, it $i$ impossible to appronch within ten miles of either stream with lurge vessels, while 
anchorage is dangerous outside on account of insuflicient holding ground, the bottom being sandy.

From the mouth of the Manicungnn River, where the strenm is alount three miles wide and grently olsstructed with shonls bare at low water, the course is direetly west for four miles, to where the rocky point projecting from the not th side nurrows the strenm to less than lulf a mile. Alove this, the west course continues two miles, with rocky bunks and, towards the upper end, with a number of small rocky islands, letween which the river tlows with n rupid current. A sharp' bend to the north now leads to $n$ succession of henvy chutes thint obstruct unvigntion for the next two miles. The river, while passing the chutes, rushes through a uarrow gorge from 200 to 300 feet wicie, with low roeky walls. The highest direet fall is alout $30 \mathrm{fegt}$, while the total descent is 110 feet. The volume of water passing down is voluue of very greit, being over laalf thut of the Ottawa at the Chandiere Falls. walle. The portuge is divided into two piuts, the upper half being only used during high water; at ot luer times slort portiges are male up or down this prit of the gorge.

A slort distunce above the uper portage, a roal climbs a high lank of modified drift, and leads to the Outardes River, some three miles thistant. This route is frequently used by the Indians, to nvoid the long const joumey, from the mouth of the Manicungan River to Bersimis, where they reside du.ing the summer months.

Above the portuge the river wilens to about 500 yarcis, und continu s from the north for five milis, after which the valley bends to the north-east, for a similar (listance, to the next portage. Severnl long islands of Irift eecur in the upper hulf of the stretch hetween the portuges. The valley is albout one mile witle, bounded by rounded, roeky hills, 600 feet high and tlankinl by thick deposits of stratified clny overlain by sund. These superficial deposits are terraced at frequent intervals up to an elevation of 350 feet above the water-level. The clny deposits do not rise more than 100 feet alove the river and are lorizontally bedilet. Thu banks and hills are well wooded with Timiner. large trees of the following species, arrunged in their order of abundance:-White birch, white spruce, nspen, black spruce, balsam poplnr, balsam fir, yellow hirch, Hanksinn pine, white pine and black asl. Nany of the spruce trees are sufficiently large to afford gond commercial timber. The current nlong this stretch groulually inerenses from two to four miles per hour as the strenm is ascended.

The next portnge is about two miles long, and, for the grenter part of its length, passes over a sandy plnin 320 feet alove the river at its lower end. Steep hills of clny und sand ure found at either end, and, 
being eonstantly wotted hy sinall streams, are very ditlieult to aseond or deseend with henvy loads. The iver here again passes, with heavy rapids and eliutes, through a low rocky gorge; the fall is 165 fret.

Above the portage the valley again willens and the next portage is thirty miles farther up. 'The course of the valley for the first nine miles is due north ; its walls are from half a mile to one mile npart, rising in abrupt roeky eliffs from 600 to 1000 fert, the river flowing close to the western wall, with a wide interval of sandy hottom-land intervening on the east side. Thes stram raries from a third of a mile to half a mile in width, nul its channel is boken in many places by sanily shonls. The entrent is even and nvernges abont thee miles an hour.

The valley next bends to the north enst for four miles, and ugain to the north for six miles, where a large hranch ealled the Toojunsteok

Trmalnuatunk River.

Chessingy l'ortage. or lilhow River, joins the main strenm. This lmanch comes in through a derp valley from the north-enst, and takes its rise in the same lake out of which the Gollout River flows. Along the lower bernl of the strenm, the mountains forming the western wall of the valley are grently broken and rise in detached rovided hills more than 1000) feet alrove the river. One of these mountains, immediately at the bend, towers upwards, with bitre roeky walls, directly trom the water, and is nomed by the Indians the "Mnnitou Pulpit." Above the bend the valley widens to more than two miles, and continums so to the month of the Toolunstook. Wide terriens orecupy both sides betwern the hills and the water, and are covered with a fine growth of trees similar to those nnmed alove. The current quirkens as the fork is "ppronched, and there flows stendily at a rate between three nul four

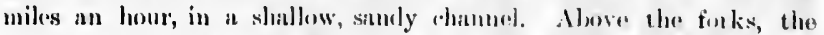
main valley changes its direction to nearly north-west, and for the next twelve miles averages a mile wide, with high rugaged hills of anorthosite forming its walls. The river here varies from 200 to 300 yards in width, and thows with i very streng current, at it winds from sirle to side down the vidley. At cich bend it routhes the rocky walls, while elsewhere it has high hanks cut out of the heivy deposits of stratified elay anci sand, which partly fill the valley in the form of termes, of which the lishest is 150 feet above the river.

At the end of this stretch a high bank of termad drit extendis almost aeross the valley, apparently tilling the wid river-chinnel and foreing the stream through a narrow rocky gorge on the enst sicke, where it descends 115 feet, in $n$ snccession of tive chutes in ahont half a mile. The prortige, maned the ('hesninp Portinge, patsises along the side of the west lank, where the terraesd drift rises 250 feet nove the water. 
For thirten miles above, the river continues narrow, crooked nnd swift, with frequent short muids and in couple of dangerous whirl. pools, in a valley from a quarter to half $n$ mile wide, surrounded by irregulur, rounded hills trom 400 to 500 feet hich. Down avery depression hetween the hills on both sides, small streams fall in bentiful cascades from the bigher lands surrounding the valley. The drift, along the lower half of this streteh, is not henve, and murrow termeses are cut into it up to alsout one lumbled teet alove the present level of the river. As the upper hre'f of the clistance is inamerer of ascended, the valley widens, and the rocky walls are somewhat lower line river and more regulnr. With the increased width of the valley the channel nlse widens to "l quarter of a mile and the current sluckens. The valley now strightitens, and for twouty uiles runs slightly oast of north, widening to nearly two miles, wi.n regular rocky walls in eillere sille. The river along this portion avernges halt a mile in bresulth ; it is very bullow, aud is broken ly a number of low, sambly islands and shonls. The current is pren and molernte, and the hauks are low, rising in willo termeses to the rocky walls. Alowt six miles up this stretch a burnt aren is entered, which extends up looth sides of the valley, fraving only a narrow fringe of green wowls at intervals along the river-margin. The timber in the valley and and the hillsides is nll of fair siog. and much of the white sprones is of gonsl quality and in suflieiont qunutity for profitable lumbering. Black spruce prodominates, follo I in decrensing order ly white

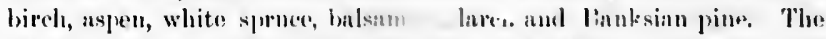
nuthem limit, in this valky, on the pine, yellow thireh and black ash njpars to be along the eren I stretehes close to the Chesniup Portitue.

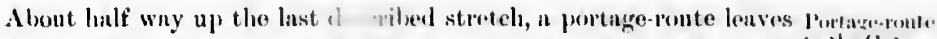
the river on its west side, ne 1, after passing over the wide, sandy or flur (hint-

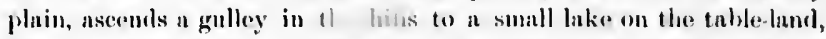
some 500 fret ahove. Thence two or three other small lakes are passerl to a harger one, caller! Tetiskouskua, the ontlot of which is de cended to the Outardes River. This is the route followed by the: Inclians who hunt nlong that strean, in order to aroid the many long portuges along its lower port.

The valley next again turus more to the enstward, and then bends to the north for twenty-anr miles, to the next portinge. It narrows, and the river becomes ik ep with a rapid enrent. The lower part of the valley contrins unch drift, which is in part termed to atheight of 200 feet nhove the river. Clay is no longer seen; the stratified sands extend downward to the water's rolge, and are often 
cappes with thin beals of the grovel. In most places the berdling is nearly horizontal, lut in a few places the angle of bedling is consillernhly inclined and the drift uppears to lave: beren, at lesst in part, deposited under on in eracks of the ghatipr. The walls of the valloy ure still rocky, mal vary from :00 to 800 feet in height. Such of the forest has Ineen alestroyed lyg tires at dilierent times, the latest having

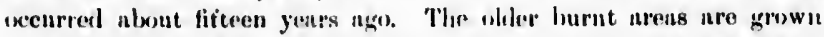
"1p witls thiekets of small white birch, aspmen, bhek spruce mol Banksim pine. On the unlument portions the tress ate conmilerably smallow thun those alrendy notel, am an qunntity of white spruce is inuch less, Whack spruce predominitting.

13rasuli l'urlugen:

Kikanlinatsa

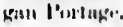

The mext portage elosstes the neck of a small peninsula, formed ly the main stresum and a branch which comes in from the enst. The portage is alume laale a mile long and jasses over a level plain of sand 250 tect alswe the river at its lrower end. 'The upper end af the

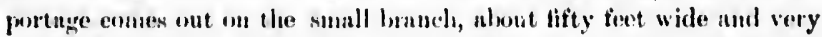
Ileep, which winls with a sluggish current betwen high sumly lunks, for nently two miles, to where it juins the main strom. The river

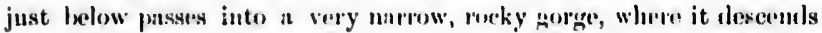
175 feet in less than two miles.

lirom the month of the small bench to the next portagn, the dis tance is five miles and the course of the valley ubout morth-west. The valley is narrow, and the hills an citlare side rise in almost per. problicular alits, directly from the water, to herights ranging from 500 to 1000 fert. A little arift is seren, torraced to 100 fent, ind through this decp, marew salley the river rushes in a deep chanuel, with many stretehes of loroken water.

The next purtage is ealied likaskuntugan, and is nearly a milo leng. It starts from a steep, roeky lengere whore, owing (1) the coustunt heavy swell, unloading is very dinsongous The boul leats up a nutrow

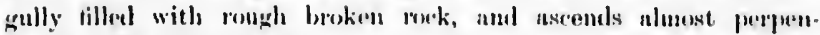
dicularly for in humber foot to a sanly terraen, which it follows to the henal of the portane, where a strep elrift hill is slescromled. Tho river

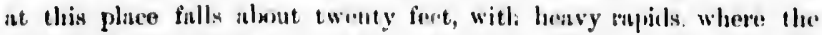

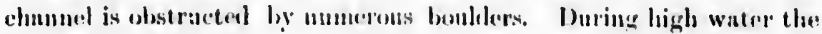
lower end of the portage annust be alpronched, and at such times a

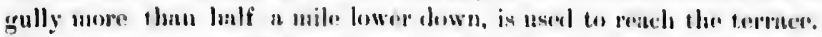

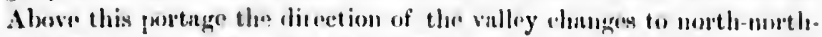
east for eleven miles. For the luwer six miles tha river avornges 100 yards in wills, and thows in a deep channel at the lake of the wertern whll, which hore rises in perpendienhar clifls firm 300 to 600 feet hight, with nuserous small stroms falling in natrow white riblums of spruy 
into the river. The eastern hills are less abrupt and are flanked by " good deal of sandy drift, terraced to one hundrel feet above the river. Along the upper five miles of this course, the valley widens and eontains much drift; the grade of the river is here very heavy and, as the bed widens, it becomes alivided into numerous ehannels by low shingle bars, over and between which the strean rushes at a rate of tive or six miles un hour, so thint it is exceedingly dillicult to ascend with londed canoes.

The course of the valley next ehanges $t o$ north-west and continues in that direction seven miles. A short distance above the bend, the walls again upproach and, two miles abwe, are less thnn a puarter of a milo apurt. As the strenu! is ascended, its ehamel narrows and deepens, and it flows w: :y mo.ddy between steep binks of bouklers on

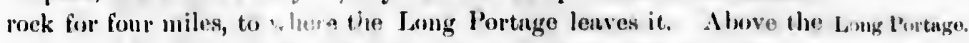
lower end of this portuge the strema is still more contructed, and is walled in by steep rocky clitfs on both sides, where it is impossible to anter or lave the valley with ennoes for the noxt three miles. In this aistance the river is interrupted by a nmmber of low chutes, which at low stugres of water can be pussed with cauoes in descending. The portage lenves the valley on its east sicle, at the mouth of 1 small tributary. A slarp ascent of 250 feet loads to a terrace of comarse sand anul gravel, formed ulong the llank of a rocky hill. This terme is followen about one mile, and then a shap bend to the north arriges the read, in the next half mile, over the shoulder of the hill, to $n$ small lake 560 fent ubove the river. A short portage leals troun this lake to a slightly larger one, from the north side of which another portage one aile and a half long again leauls d wwn to the river, after first passing wor a flat drift phain botween the lills. The trees surromoling the lakes are mustly small bluck spruce, with a few tir, harch and white spruce, nowe of which are of commercial value.

Alwore the Jong l'ortage, the still contracted valley stretehes due Character of north for three miles, when it changes to north-uorth-enst for eight valley uhwor miles, to the next portuge The river, along the lower half of these Portage. distances, is cleep, nurvow and very swift, with steep banks of rock or large imoniclers. Alung the upper half it alternates lotween leng stretches of quiret water, and short rupids, where heavy banks of cearse drift preject out from the sides, contracting the channel.

The prortuge, at the hend of these courses, is about 100 yords long,

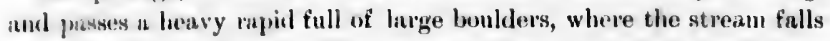
wer a low leclge of rock. From here, to the outlet of lake Ichimnvicungan, six miles above, the valley continnes in the same direction $12 \frac{1}{2}$ 
us the last course, and grabunlly wiflens to about one mile. The hilly forming its sides rise very nturuptly from 600 to 1000 feet, and in unset plnees their sides we hare rock, with stmegling spruce surl hirch trees growing heres and thepe in erevices. The river gradually widens, and after a short rupisl, about two miles abwe the fortuge, its current shekens, and it passe's imperceptibly into the lake. The roeky walls are tlanked on both sildes with some quantity of drit, che into ternees at various heights, up to 1:00 ient above the wnter, these

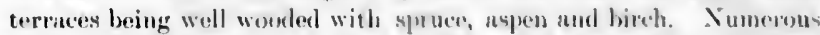
large tres of white spruce grow on the lower terraces, many of them

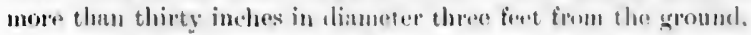

Jakk. Iwimaniengath.

I'rivions*tirvity.

Tritulurus.

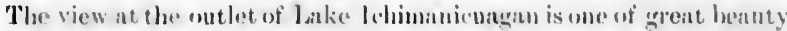
and grandeur, the equirt water of the latke contrasting in colour with

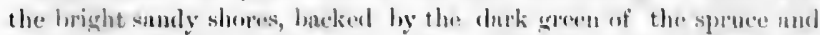
the lighter-colesured bireleses and aspen, while the rocky walls of the

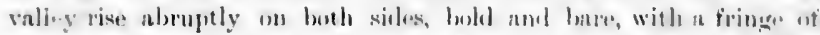
small trees erowning their summits. Ont of every depression in the hills alrowe a stremm issued, filling in most places directly dow th the

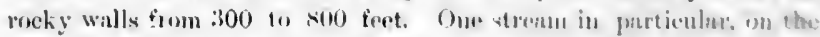

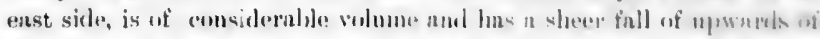
500 tret. In its deseent it dashes agninst the alowet prerpurdicular

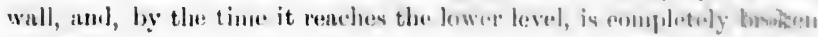
inter sprny.

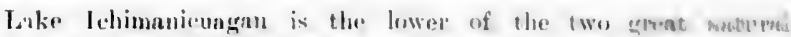

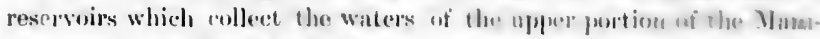
cungan liver. The lake lies in a derep morww valley, a comtinuation

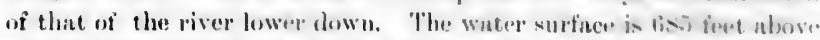

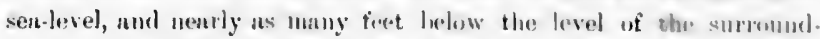
ing country. This lake was not exionined ly ar. but was surveyed in

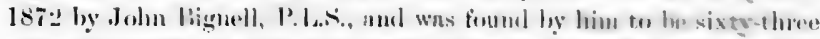

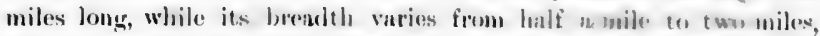
giving an averuge brendth of one mile, the southron halt being the narower. The lake is eresernt-shupend, so that an line Irawn from the two ends runs nearly nort!-mul-south, whith the comvexity of the eurve is towards the anst. Tlye prinepal rives flowing inte the lake, enters it on the west side, nbour four miles nbove the omtlet, res: forms the discharge of Lake Mouehalagnu, the upper latge lake. The other large streams entering the lake are three in mumber, but they do mot eompare in volume with the lnst mentioned. T'wo come in on the enst side: the lower, ealled (inbriel liver, enters alout half way up: the other, called Wachnegionatu River, flows in about tro mirs from thes north end, and is used by the Indius as a route crossing to the brind 
waters of the ste. Marguerite liver. The third river flows intu the morth end, and is exceedingly mpid, ns it descemds quickly from the table-land to the level of the lake. It rises some forty or fifty miles to tho north and nortli-enst, in a mumber of lakes, of which the wuters interlock with those of the mnin strean on the wast, the Ste. Mnrguerit. an the enst, nud triluturies of the lioksonk Rivor on the north.

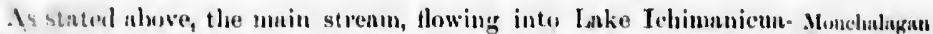
gatu, comes in from the west alont four miles from the ontlet, liver. This river, whieh ergats at least thee-quarters of the volume of the ont. let, cinters the lake though a deep uarrow gorge, nenrly at right-nugles to the main valley, and also ents aluost directly neross the strilie of the rocks. For three uniles alowe the lake, the valley is not owe.y 200 yards widle and is walled in by rocky hills, which on the north side rise in perpendieu!ar cliffs from 800 to 1000 feet; the south wall is apgully high, hut less abrupt, and is about one halt woulded with

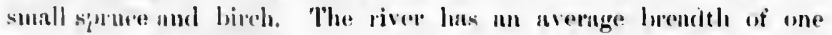

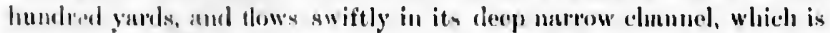
freepuently patly bilexked with huge masses of nugular rock, fallen from the overhanging clifls of the north side. Soveral small strems tumble in from the high londs en the sonth side, in series of bratiful warrifalls. After three miles, the valley curves gently towards the north fin four miles, wilening in so doing, and thus allowing tor a narow interval of terraced drit between the river and the walls of the valdy. The cast wall eontinues ahrupt, lout further up the strenu it gridically decrenses in hroight, mad the seencry leses much of its wild stameleur. The course of the vallay anst changes to nearly worth. east, here it widens, and its walls heeome lower and mueh less rogged, so that in the upper part, the storeounding hills do not rive more that ino feet alwe the stream, and lawe well wooded, rounderd outlines. The corrent thomghout is swit, and two miles up this

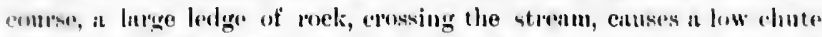
and heaty rippid, passed by a portage of one hundred gards on the enst sille.

At the upper end of the cours, the stream lwends quickly to the lonere rapids. nortli-wrat, surel tor more than a mile is broken into browl low chutes and leary rapids. This olstruction is passed by a portage nealy a mile long, of which the lower end is found is short distanee up a smull strean which thows in on the west side at the foot of the mpicls. Tlar portage rises rapilly 170 fort, to the level of a flat sundy terraer, aud then eruses uorthwarl; on the level, to the river, Where a shutp sen'perd Inink of stund is descenderl. 
From the uper end of the portinge, the strenm gradunlly bents to the westward for the next live miles, to where it Hows ont of Lake Mouchaligan. Meng this portion the lanks are not ligh, and the rounded rocky hills are quite distant, so that the country on either side of the river is low and that, and is thickly wooded with spruce, linnksinu pine, tir and birch, somewlunt smuller thun before noted.

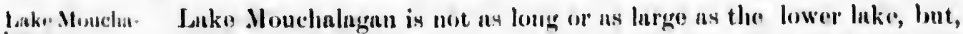
lagau. notwithstumling, contnins a grent volume of water. Its grestest length is furty-one miles, anol its avernge brendth ahout me mile, being least in its southern half, and varying from one mile and a balf to two miles in the northern part. In shupe this lake nlso resembles an irmoglar are, hut with the eonvexity townals the wort. ; on aceomut of the opposite hends in these long lakes, their northo.. ends npprench within fifteen miles of ench other, and the interval there is secupied by low lands covered with lakes.

Mighu nims. The lovel of the lake is 830 fert aluve the sen, and its water is rem. remnikntly deep. Soundings made ofl' Partrilge-tail Hill, on the west side, about fifteen miles from the north end of the lake, give n chepth of 466 fret, at ome hundred yards from shore: while at a distunce of s00 yards the depth is 65i) feet, the grentest known depth of any lake in the Iabrailor Peninsula. The water is elen', with ab brownish tinge.

Fish. Owing to the great dopth, but few places are suituble for the sitting of nets, and consequently the lisheries are not well known to the Imlians except in the northern part, where the sand brought down by the prineipal tributary has silted up the hottom and produeed slatlow water over a cousiderable aren. Here large quantities of lake trout, whitefish, lund-locked salmon, pike and suekers are taken in nets during the spring and autumn.

The sliores of the luke alternate between wide rocky points und sandy hays, and the banks in must places rise in terrices eut out of thick cleposits of drift that llank the roeky hills on both sides. The highest torrace is about 150 feet above the present level of the lake, and it is seon on both sides in all favourable lecalitios.

The lills are, for the most jart, well rounded, but broken by leep valleys, those on the west sicle rising from 200 tu 500 feet above the water. On the enst side they nre low and regular until the middle of the lake is renehed, where n range of ligh irregular-shaped hills of rusty gnruet-diorite oceupies the euuntry bnek from the shore for more than ten miles, when they again die nway in the low lands at the heal of the lake. To the north of the lake a low flat euntry extends for 
some ten miles, to the fous of a hight uregular range of hills, which, from therir outline and white colour are believel to be formed of erystal. line limestune - an extension of the hills seen along the river above the

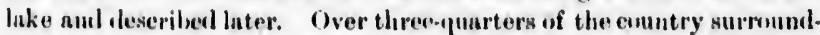
ing tho lake has, within the last three yours, boen clovastuted hy the,

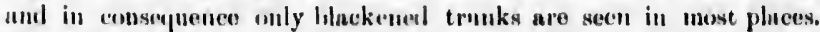

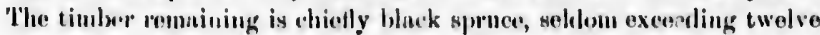
inches in dianoter, together with white birch, balsum fir, aspen, Banksinu pine and a fow larch, all growing thickly, but sunull in size.

A number of sumall rivers enter the lake, generally with fulls elose Tributurien. to thrir moutl. Most of them some in on the west sicle, nunl one of them, which muters "few uilus soutl, of the Partrilge-trnil, forms with its connected lakes, a route to Outurdes River. The muin stream,

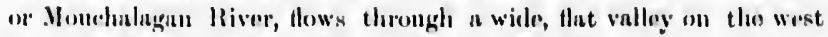
side, ubut tive miles from the north ond of the lake.

As before stated, wide shouls extend for more than a mile into the

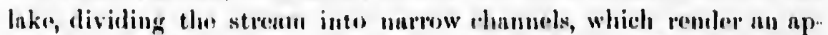
proacli diflicult during low stages of wntcr. For the first four uniles from its mouth, the strenu flows from the north-north-west in a elum-

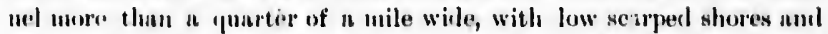
samly shallow lerttom, with a modernte eurrent. At the heml of this eourse, " large branch, enllod the Knwikwasipinis River, joins from kawikwan-

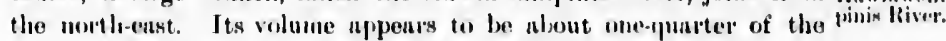
main strenu below its junction. It is ulout 100 yurds wisle and

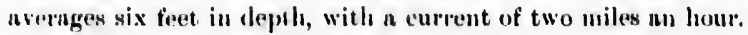

'This river, a slort distance ahove it. mouth, passes in 1 deep narrow valley, between high rugged hills of white crystulline liuestone. From information obfained trom the Indiass, who hunt along the streaw for many miles ahove its mouth, it is a succession of loughouvy rapids and quite unnuvignlle, until nest its hend, where it thows out of " lurge laki ialled Mishinik, some tifty miles to the north-enst of its mouth and elose to the uorthern watershed. From the north end of this lake, portuge-routes throught sunall lakes leud north and northrost into the headwaters of strenms flowing north into the Koksonk River, and enst ward into the Moisie River. The portage-route to Lake Mishinik and past the rapid lower purt of the river, is hy a small tributaly which joins the man stren fourteen miles above the liawikwanipinis. This poute is exceelingly long and rough, and yuite inpassal,le during the sumuer mouths for heavily londed cunnes, owing to the shallow streans and lakes connected by more than fifty portages, many of whieh are long an'l puss througl deepswamps. The lndians 


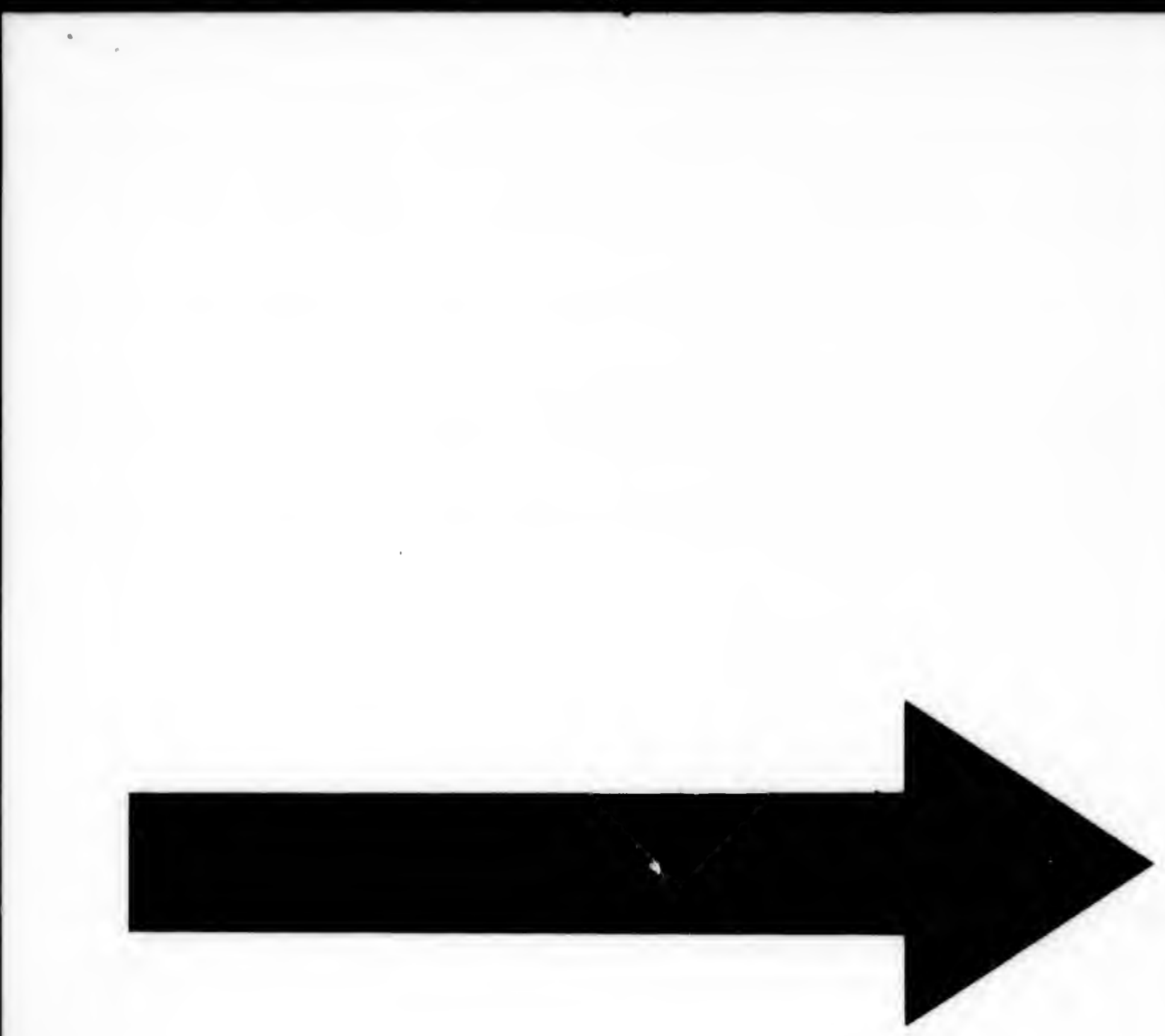


wait at Lake Mouchnlagan until winter sets in, and then haul their canoes and outfit over the portage-route, returning in the spring in their eanoes. At this time they carry out only the furs caught during the winter, and in eonseqnence pass over the portages in one trip.

Above the Kawikwanipinis, the main stream, for the next fourteen miles up to the small tributary ahove mentioned, has a general direction from the nertl1-west, with $n$ number of minor bends on both sides of the course. It new enters a ristinct valley, which narrows from a mile to less than half a mile acress is the stream is ascended, with recky walls High:cliff. from 300 to 500 feet high, of ten with perpendieular eliff-faces, especially along the upper half of the distance, where white crystallino limestene and rusty, deconiposed gneiss are the prevalent rocks.

For tive miles above the forks, the channel averages 200 yards in width, and a stearly current flows over the sandy shallow bottom; farther up, the stream is broken inte numerous eliamnels by long islands of drift, often well weoded with medium-sized white spruce and white birch. The current here becomes swift with shert shallow rapids, and poling is necessary in ascending with canoes. In many places thick sections of false-bedded sands and gravels are expesed in the scarped banks, and well-marked terrices were noted at 10,20,40,60,70, and 100 feet above tlie strem. The lower ternaces are thickly wooded with trees similar to those found on the islands, along with black spruce, which predominates on the upper terraees and on the rocky sides of the valley. Abeut one-balf of the ferest in the valley has been recently burnt.

The valley now turns due west for two miles and a half, and then nearly north for three miles and a half. Throughout these distances the river passes through a narrow recky gorge with walls rising from 200 to 500 feet. The channel, in ascending, first narrews to about fifty yards and eentinues so for more than a mile. The current is very streng, and increases inte a heavy rapid, with a low chute where the stream passes over a ledge of limestone. Above the chute the stream widens to 300 yards und is breken into numerous shallow ehannels by gravel bars and masses of coarse blocks and houldeis. The strean here deseends with heary rapids. At the bend, the valley and river again narrow, and the latter varies frem ten to 100 yards in width as it pasies down over a number of shert chutes connected by heavy rapids.

Gorge. Wit' this eharacter the strean continues to the head of the gorge, where the valley gradually opens up, and as it widens it becomes free from roeky ledges. This pertion of the river can be navigated with canees only at low stages of water, as then only can portnges be made over the recky nurgins between the steep walls and the water at the chutes. 
The Indians never use this part of the stream; they pass it by a portage-route of which the lower end leaves the main stream on its east bank a few yards above the mouth of the already-mentioned tributary. The portage is short and ends on this stream, which is followed northward for a mile and a haif in a direct line, but, owing to the stream winding from side to side in a valley about half a mile wide, the distance by water is more than four miles. The direction of the route now changes to nortl.west and continues nearly so to the head of the gorge. From the stream a portage of a mile and a half leads to a smull lake 450 feet above the river. The route next passes through Portage l:ast three small lakes connected by short portages, for two miles, and then the gorge. by a portage of a mile and a half down hill to the river. The country surrounding the lakes is characterized by rounded, rolling hills partly covered with small black spruce and larch, with a few birch trees.

From the head of the portage, the valley runs nearly due north, and quickly widens out to nearly one mile, with its bordering hills rising gradually on both sides to heights varying from 300 to 600 feet. The river has an average width of 400 yards for the next five iniles, up to where the main portage-route leaves it. The channel is shallow and greatly broken by drift bars and low wooded islands, witlı a very swift current that a verages five miles an hour and is occasionally broken into short rapids. Between the hills and the water there are wide intervals of terraced drift, the highest terraces being about 100 feet above the water. Scarped banks show the drift to be chiefly fine sand, with occasional beds of small gravel near the top, all showing signs of bedding at various angles to the horizontal. The trees in the rulley continue to be of fair size and are chiefly black spruce, with white spruce, balsam fir, white birch, aspen, larch and Banksian pine.

The main stream, a few iniles abóve where the portage-route lealves Portage-ronte it at the head of this stretch, becomes very rapid, and flows in a deep, to lead of narrow gorge, with high, steep, rocky hanks, where it is impossible to ascend with canoes, and very dangerous to descend. On this account, the Indians make use of a long and difficult portage-route, in order to reach the upper waters of the river. This route was passed over in ascending to the watershed, and will be described further on.

Above this portage-route, the valley continues northward for seven miles. Along the lower part it is somewhat wider than the portion last described, and the river is also broader, with higl drift banks, from bencath which rounded masses of rock outcrop at intervals.

Along the upper three miles, the valley gradually nirrows and the drift on the banks of the stream give place to ruck, which hems it in 
and, as the grade is henvy, causes it to form wild apids in a channel less than 100 yards wide.

Peprechekau River.

Dangerons rapids.
On the east side, about one mile below the upper end of the course, a large branch called the Pepechekau River, enters the valley with a beautiful fall of fifty feet. This stream heads in the neighbourhood of Mishinik Lake, to the north-eastward.

The vulley, for the next twenty miles, runs almost straight northnorth-west, with only a few minor bends. For the whole distance it never exceeds 400 yards in width in the bottom, and for many long stretches i; less than one hundred yards across, with high, rocky banks rising abruptly from 300 to 600 feet, to the level of the irregular table-land ahove. The grade of the valley is iteep, and down it the river, much contined, rushes in wild, heavy rapids, broken occasionally by short, low clutes. The shore is rocky, and broken with small, irregular points, past which the water rushes with great velocity and thus forms dangerous whirlpools. This portion of the river is exceedingly dangerous to travel, owing to the impossibility of making portages in most places, on account of the high, perpendicular walls of the valley and of the absence of any beach between their foot and the water. During the descent of this portion of the river it was only with the greatest difficulty and danger that the frequent lardings necessary for the survey were made, and disaster was avoided in a number of places only by good luck. At a rapid pitch about half way down, one canoe was accidentally upset, and Pitul Bacon, an Indian guide, was most unfortunately drowned ir. the whirlpools. Although the river was carefully searched below, no trace was found of the body of the unfortunute ynung man, nor of the canoe or its contents, which must have been caught in some of the eddies and sunk out of sight beneath the deeply-eroded, rocky banks.

Along the upper mile of this course, where the river first passes into the cañon, it falls 140 feet, in a succession of chutes over rocky ledges, the stream being broken into a multitude of channels by small rocky islands. The trees along the walls of the cañon are chiefly black spruce and a few white birch, with an occasional tree of white spruce along the lower portion.

Above the head of this gorge, the hills on both sides fall away, leaving a valley several miles across, bounded by broken ridges of rounded hills from 100 to 500 feet high. The valley is filled with a great accumulation of drift arranged in low ranges of drumlin-like hills, covered with boulders. The river now spreads out, and is broken 
into numerous channels by the detached drift ridges, so that for the next fourteen miles it assumes a lake-like character, although everywhere the current is perceptible and in many places strong. This portion is called Natokapau. The stream continues to flow from north-north- Notakapau. west for eight miles, to where a large branch called the Attikopi River joins it from the westward. The main stream, or Itomami Branch, then changes its direction and flows almost due south. Several large streams from the surrounding country join the main river in this neighbourhood. On the west sicle two tlow in below the Attikopi River, and drain small chains of lakes on the high lands, through which a portage-route passes to join the Attikopi River. Two other streams enter on the east side, within a short distance Branches. of the commencement of the cañon, while at the upper end of Natokapau a large branch called the Mossy-pine River, joins from the north-east, where it is suid to head in severul long lakes on the watershed, one of which, at least, also discharges northward into the Koksoak River.

Above the Attikopi, the main stream flows in short crooked courses down a valley from one to four miles wide, bounded by rounded hills from 200 to 500 feet high, that run in broken ranges parallel to the direction of the valley, or north-east and south-west. The lower lands surrouncling the river are covered with ridges of drift, often largely formed of coarse boulders and angular blocks of rock. The sumnits of all the higher hills rise above the tree-line and are covered only with low arctic willows and shrubs. The trees growing on the low lands are small and stunted; over ninety per cent are black spruce, with a few larch and Banksian pines, and an occasional clump of small straggling white birch. The aspen is not found above the mouth of the Attikopi R, ier.

The valley continues in a north-east direction for forty miles, up to the watershed, beyond which it was seen holding the same course for at least thirty miles farther.

Above the Mossy-pine River, the main stream is about one hundred Character of feet wide in rapids, where the average depth is under two feet. Inl- the upper mediately above its junction there is a short heavy rapid leading from a small lake-expansion connected by short rapids with three others in the next seven miles. Above these, for twelve miles the river is narrow and blocked with small islands and huge boulders, past and over which it pous in continuous heavy rapids. It then flows out of the lower of a series of lake-expansions that almost fill the bottom of the valley, and are only separated from one another by short heary rapids. These continue for ten miles, until the outlet of Lake Itomamis is reached. This lake is five miles long, and from one to two 
Itomanis miles wide, with several stall irregular bays stretching awny from the Lake. main body. It is surrounded by barren-topped hills that rise from 200 to $\tilde{0} 00$ feet above it. Low shores, backed by drift ridges, intervene in many places between the water and the surrounding hills, and they are covered by patches of stunted black spruce and a few larches. The lake is fed by two large and a number of small streams. The largest flows in on the west side, near the south end, und forms the outlet of a chain of lakes on a portage-route to the liead of the Attikopi River as described further on.

The second large stream flows into the north end of the lake, and, by two short rapids and a small lake-expansion, connects this lake with Itomami or Summit Lake, so called on account of its waters dischurging in opposite directions; the southern outlet forming the head of the main branch of the Manicungan River, the northern flowing into Lake Kaniapiskau, and thence into Ungava Bay. The streams flowing out are about equal in size and volume, being about ten fect wide in the ripids of hoth discharges.

summit Lake. Summit Lake is cut by the 53rd parallel of north latitude. It is six miles long, and averages about one mile in width, with two lateral bays, which increase the width in the centre to three miles. It is estimated to be 1940 feet ahove sea-level. Like the lower lake, it is surrounded by rugged, rocky hills, arranged in roughly purallel ridges. These hills are all barren on the top; on the low linds sulrounding the lake small black spruce grows, but only in open groves. A great part of the timber has been clestroyed by fire, and the landscape has a most desolate, barren appearance.

Country about

From the summit of a lill that rises 565 feet above the water, the watershed. situated on the east side of the lake near its north end, a fine view was o!tained of the country about the watershed. The valley of Itomani is seen continuing in a north-north-east direction for more than twenty-five miles; beyond, it appears to bend towards the north, and a chain of long narrow lakes partly fills the valley, down which they discharge into Lake Kaniapiskau. Another wide valley stretches off towards the north, with two large lakes, the upper of which appears to be about 200 feet above the level of Summit Lake, into which it drains. To the westward are two more lakes, the lower separated only by a narrow strip of sand from Summit Lake. To the south, there is a narrow valley containing a chain of small lakes. With these exceptions, nothing is seen in all directions but rounded, barren-topped mountains, apparently considerably higher to the east, north-east, and norih than about the lake, and the elevation of these mountains may vary from 300 to 600 feet above the lake, or from 2000 to 2500 feet above sea-level. 


\section{Attikopi Branch.}

This stream, as before mentioned, joins the main river in u small Junction with bay at Natokapau. At its mouth there is a short rapid where the main river. liver pusses down a channel about one hundred feet wide, over and between large boulders. For ten miles it flows in an irregular channel between low ridges of difft, thickly strewn with boulders and angular blocks of rock, on its way down from Lake Attikopi. The stream is great:y broken by rapirls and clutes, and descends over 250 feet in the ten miles. The grade of the upper half is the heavier, and low ledges of rock along this portion cause frequent chutes. In all six portages, aggregating four miles in length, wre necessury to pass these obstructions. Besides the low houlder-strewn ridges, occasional low hills of rock rise above the general level, and bccome more marked as Lake Attikopi is approacherl.

This lake is very irregular in shape, and its surface is broken by many Lake Attikopi rocky islands. A long point, stretching out from the south side, divides it into two buys, with a third trending towards the north-east. From the discharge, at the south-east end, to its north-east inlet, the distance is abont five iniles, and its grentest breadth is about four miles. It is surrounded by broken ranges of rocky hills, from 200 to 400 feet high, the widle valleys between being characterized by low ridges of drift. Over one half of the forest has been destroyed by fire, and the remainder is chiefly small black spruce and larch, with a few Banksian pines and birches. Here the river divides into twe branches of about equal volunie. That flowing into the south-west bay is culled the Kiche-wapistoakan River, while the one entering the north-west angle of the lake, is cal'ed the Attikopis River. The former flows from the south- South-west west, where it rises some forty miles away from Lake Attikopi, in branch. a number of small lakes whose discharges interlock streams flowing into the Peribenkit and Outardes rivers, with the head-waters of the Manicuagan River. This stream was explored for twenty miles above its outlet, to where a small tributary passes into Lake Kitchewapistoakan, on the portage-route past the unnavigable portion of the Moucha.

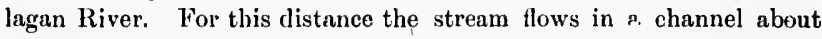
one hundred feet wide, generally with a sluggish current, except at short rupids which oceur at frequent intervals. The channel is very crooked, and the banks seldom show solid rock, being for the most part composed of sand and generilly low. The main direction of the stream is determined by sharp irregular ridges of sand, which bound its western side. These ridges are nearly continuous and where they are cut Great esker by the river, show the false-bedded structure of an esker, or deposit ridge. 


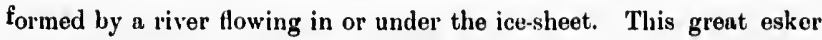
was traced for more than twenty-five miles beyond Lake Attikopi toward the north-east, while in the opposite direction, according to the Indians, it extends almost to Lake Pletipi on the Outardes River, or n total distance of netrly one hundred miles. It is a marked physical feature in its south-western half, where it traverses wide swamps, and is used as a highway by the Indians in their winter travel. On the enst side of the river, the country is covered with low, drumlin ridges of coarse till.

Highest aren of central Labrador.

Attikopis Branch.
From the above description, the general surface of the country surrounding the river will be seen to be low and nearly flat, and it is only broken by occasional isolated rocky hills that rive from 200 to 400 feet above the general level. According to the Indian guide, the upper, unexplored portion of the river preserves the sume character, flowing nearly on the surface of a wide swampy plain broken only by the esker ridge and by $n$ few low drumlins. This plain extends northwards about ten miles to the font of a high range of baren lills that rises 500 to 1000 feet above its level, and constitutes the highest area of central Labrador, being about 2400 feet above sea-level, forming the watershed between the Big River of Hudson Bay and the rivers flowing into the St. Lawrence.

- The Attikopis Branch tlows from the north-east, where it takes its rise in Lake Attikopis, or Little Attikopi, some twenty miles from the larger lake. The smaller lake is less than three miles long, and is divided by two narrows; it is chiefly of importance on account of two portage-routes which join here. One, from the westward leads to Nichicun, the other to Summit Lake. The Attikopis River, below the lake, flows in crooled courses in a wide valley bounded by rounded, rocky, isolated hills on the east side and by the higher range of granite hills on the west. Two spurs of this range rise close to the liver. The valley is broken by low boulder ridges, with extensive swamps and snall lakes between them. This country is partly covered with small, stunted black spruce and a few larches, while the hills are almost wholly barren. The river-channel is very irregular and occupies the depressions between the drift ridges. It practically consists of narrow lakes, connected by short rapids, where the channel is lined with boulders. Before reaching Lake Attikopi, it passes through a lake three miles long and about one mile wide, below which a mile of rapids and strong current leads to the large lake. Little Attikopi Lake is fed by two large brooks, both of which head in the mountainous country westward of Summit Lake. The portage-route follows the the eastern strean, almost due east, for six miles by its winding chan. 
nel, to a lake about two miles acress, surrounded by high, rugged, barren hills. Above this lake the strcam is too small for canoes, and portages me male aiong it between the three small lakes at its head; these portages are respectively one-half, two, and one mile long. The portage over the watershed, between this stream and one flowing inte the muin branch, is about a mile and a half long and passes over a ridge between high, rugged hills, which surround the route. These hills are semi-barren, and the country has a very rough, disolate charncter.

Four smull ponds, comnected by a little stream, lead into a larger lake, about four miles long, thedischarge of which is navigable with canoes, and, in a mile and $a$ half to the next lake, it is breken by several rapids. This lake is n mile long and empties by a short rapid inte Spruce Mountain Lake, which is four miles across to its southern angle, where it discharges, A narrow bay runs up a deep valley to the north wnrd, and the lnke is filled with islands and surrounded by high hills. The discharge is characterized by heavy mpids for two miles, to where it enters Itomamis Lake.

\section{Portage-route betreen Lake Attikopis and Nichicun.}

The portage-route to Nichicun leaves Lake Attikopis by its western Route to tributary, which is ascended for about one mile; then a portage of over Nichicun. a mile leads to a little lake that empties into the small river. From this little lake two portages of a mile and a half mile respectively, with a small pond between them, end in a narrow lake, one mile long, connected by a short portage with a larger irregular lake, nearly three miles long. The general direction of this portion of the route is almest due west, and is through a wide valley surrounded by barren, rocky hills, from 300 to 600 feet high. The only trees seen skirt the lakes or grow in the swimps, the remainder having been destroyed by fire, leaving exposei low hummocks of drift thickly strewn with boulders. A portage of a quarter of a mile crosses the watershed and ends in a small lake drained by a tributary of the Big River. The direction of the route now changes to nearly south-west, for nine miles, as it passes first through a lake two miles long, connected with the next by a river stretch of one mile, with three portages past rapids, followed by a lake for five miles and another river stretch of a mile, with several rapids. A change of direction next occurs to west-north-west for the next twenty-four miles, nlong which course the stream passes through seven small lakes, and is greatly augmented by the junction of small branches from the lakes that partly fill the surrounding valleys. 
Between ench lako thero ure henvy rapils, so that the large lake, called Naokokan, into which the river empties, is some 200 feet bolow the level of the lake nt the watershed, or nealy 1800 feet above the sen. The eountry surrounding the river is rough, lout the rocky hills near the valley die away to the south and west as Naokokan is npproached. Recent fires have destroyed the greater part of the sinall stunted, black spruee ant harch, which parlly covered the lower lands.

Lake Ninok Nuokokan is a larę, irregular lake, nearly eov'red with islands and knil. deeply indented with bnys. Its grentest length, of thirty miles, is from enst to west, while its width appents to be nearly twenty miles. From an elevntion of 300 feet, nenr the mouth of the river, the lake had the appenrnnce of " wide plain coverel with numerous smull lakıs, and it was found only on passing into the laki, that these numerous sinall lakes were really connected by struits and passages. Three days were spent in examining the southern shore of the lake in search of its outlet, and in that time only one of the deep western bays was explored. Owing to unfivourable weather-heavy south-west gales, accompanied by rain and fog, - and failing supplies, the exploration was ended hele, without the outlet being found and descended to Nichicun. It has since been learnerl that the outlet is somewhere near the north-enst angle of the lake, and that along it the distance to Nichicun is not more tham twenty-five miles.

A lurge branch was diseovered, falling with henvy rapids inte the south side of the lake. This is the main stren of the Nichicun River, and takes its rise in a number of small lakes to the south, along the northern slopes of the mountains forming the watershed between it and the Manicuagan, Outarcles and Peribonka rivers. South and west of Take Nrokokan, there is a wirle, flat plain, loroken only by small isolated hills, and covered with innumerable lakes; to the north and north-east, the high mountains of the vicinity of Nichicun are seen with their rugged barren tops.

\section{Portage-ronte used in Ascending the Monchalagan River.}

As previously stated, $n$ portage-route leaves the west bunk of the Mouchalagan River, about twenty-five miles nbove Mouchalagan Lake. A description of this route is intelligible only by reference to the map, as it follows a succession of portiges joining little lakes and streams that lie in small valleys between the hills of the table-land, high above the level of the river-valley. The first portage is a mile and a quarter long. It leaves the river immediately above the mouth of $n$ small stream and follows up its valley to a little lake on the table-land 620 
feet above the river. There is a very murkel change in the size und vurioty of forest trees between the ends of the portnge. It the river there is a dense growth of mediun-sized, blnck and white spruee, balsum tir, Bunksinn pine, luch, white birch und aspen, while, nbout the small lake above, only stunted bluck spruce and Bunksiun pine sepurnted by open gliudes, ure found together with $n$ fow lnreh ubout the swanpy murgin of the lake.

Crooked courses for two miles lend to the west end of the lake, whence $n$ portage of half a mile, then $n$ poud, followerl by n portage of n mile, leml to a chnin of very sinall lukes, on the henl-wnters of tho strenm, at $n$ level 200 foet nbove that of the lower luke. Three small lakes joined hy inpids follow, to a portage one-third of a milo long, thresugh a swanp, ending in a marrow, crooked strean which is aseeniled about $a$ mile and then left by another swimpy portnge half $n$ mile long, erossing the watershed between tributaries of the Manieungnn and Outardes rivers at an elevation of 1680 feet nbove sea. level, or 770 feet nbove the river at the commencement of the portageroute. The country surrounding the route is rolling, being broken by Character of short, isoluted ridges of rounded hills, that rise from 100 to 400 feet the country. above the wuter level. Wide valleys lie between the hills, covered either. with small liakes or swamps, and with frequent low ridges of boulder's riving above the lovel. The soil is scanty, and everywhere boulders and lurge ungular fragments of rock are scattered in profusion, so that there is no ditheulty in walking in any direction over the higher ground without stepping off these, while in the swanps the portage roads frequently lead along ridges of packed fragments, witlout any fine materinl between, and only partly covered with a deep conting of sphagnum, or white moss. The trees growing on this poor soil are small and stunted, and over ninety per cent are black spruce, with only a few groves of Banksian pine and small larch in the swnmps.

From the height-of-land portage, the route for five miles follows a small stren connecting four little lakes, with short portages between them, und so reaches Little Matonipi Lake, about four miles long and a mile and a half wide, studded with many small, rocky islands. A portage of a mile and a half leads from near the discharge, at the north-west corner of the lake, to the eastern bay of Matonipi Lake. This bay is about two miles long, and from its Matonipi mouth $a$ northern bay extends four miles to its hend, where the Lake. portnse-route leaves it. Another long bny extends southward severul miles, with a small river flowing out of its head, to join the Outardes River some twenty niles below the outlet of Lake Pletipi. The lake avernges a mile in width, and is surrounded by rocky hills that rise 
in rounded outline from $\mathbf{2 0 0}$ to 500 feet, those on the west side being the highest. This western ridge is only $\mathrm{n}$ fow miles ncross, nucl an old portnge-route leads over it to Jake Pletipi, some flfteen miles away.

The direction of the portage route to Iake Mntonipi has leen nearly due west. It now clannges to north, and con' inues near that course until it renches the soutli-west brnneh of the Attikopi River. The surfnce of the luke is $\mathbf{1 6 4 0}$ feet nhove sen-level. The next lake at the upper end of the portage is two miles distant from the north end of Mntonipi?; it is nbout three-quarters of n mile neross, nud 270 feet above Matonipi.

From this lake another portnge of two miles lends over a burren, rocky ridge thickly strewn with boulders, into n narrow gully filled with small ponds, connected by a brook which discharges into Lake Matonipi. The rise on this portage is 350 feet. The route con. tinues up the gully, and passes in the next four miles through tive Highest level. ponds, with intervening portages, to the height-of-Innd letween the waters of the Outarles River and a small branch of the Mouchalngan River, at a height of $\mathbf{2 3 9 0}$ feet above sea-level, and ono of the highest water summits of the Iabrador peninsula.

The portnge over the summit is more than n milo long, and passes between low, rounded, rocky lills, covered with blocks and boulders, and end $v$ in a small swampy lake, out of which issues $n$ stream too small to be descended by canoes.

Two miles of portage, over boulders and through swamp, lead to the junction of this stream with a somewhat larger one. The portnge here crosses to the west baik, and for two miles and a half farther, follows down stream, on the sumnit of a narrow esker of strntified sancl.

At the lower end of the portage, the stream is nhout twenty-five feet wile, but soon inereases to fifty feet, below a small north branch, where it has a shallow channel, sandy bottom and sluggish eurrent. This stream was followed for three miles and $n$ half, and then left by a short portage to a pond, followed by another portuge of half a mile to $n$ sniall lake without any outlet. From this lake a three-mile portage leads northward to nnother pond connected with a small lake by a portage of half a mile. A similar portage leads from this to a larger lake, which is followed northward three niles to its end. This lake empties by another branch into the main river. The next three miles are occupied by five portages, which pass up n shallow valley, surrounded by drumlin hills of coarse drift, and containing five small ponds. The next lake is two and a quarter miles long, and is left by a half-mile 
portage, ending in n small lake-expansion of the dischinge of that lake. The disoharge is followed for $n$ couple of miles, and then $n$ small branch is ascended a short distance, to a portage of $a$ quarter of $n$ mile, past rapids, to a small lake above. Five portnges connecting ponds accupy the next three miles; then a small strenn is renched and descended for about one mile, after which a two-mile portage leals to a pond connected by a short portnge with a lake nearly two miles long, from which a portage of a half-tnile lends to Lake Kichewnjistonkan on " sulull strean flowing into the south-west branch of the Attikopi River already described. This lake is of no great size, and is liroken into South-wewt decp inregular lings by low points of drift and rock. It is chiefly re krupi Kives. markable, on account of its possessing two discharges, both of which enter the valley of the main river within a short distance of ench other. In the spring, when the Attikopi brnnch is in freshet, its water backs into the lake, and flows out by the second outlet, which nt ordinary tines is nearly dry.

The country and timber from the watershed to this place is similar to thit alrendy described. The only difference being the incrense of drift on the northern slope, in the form of till nud sand or esker-like deposits. Tho only trees are black spruce along with a very few lareh, and all are stunted and confined to the valleys.

\section{GEOLOGY.}

The following notes on the various geological formations of the source of in. Labrador Peninsula are tho result of observations made along widely formation. separated lines of exploration in that great territory, and the time given to the work was very limited. It will thus be understood that they afford only the means of uaking $a$ rough estimation of the distribution and extent of the areas of the different rocks, with some general remarks on their relations, modes of occurrence and age, together with a more or less detailed statement of the various exposures of rock actually examined along the routes followed.

The descriptions of the different rocks are from olsservations made in the field, together with a microscopic examination of the hand specimens brought bnck. It is to be regretted that circumstances prevented more than a small number of microscopic sections being made. These have been examined by Mr. W. F. Ferrier and des. cribed in Appendix V.

\section{Geological Formations.}

The term Laurentian is employed to designate the complex mass of Lnurentian. highly crystalline Archenn rocks of which the greater part of the $13 \frac{1}{2}$ 
Labrador Peninsula is composed. These do not differ in any essential particulnrs from those similarly designated in other parts of Canada. They consist chiefly of gueisses and schists, some of which are believed to be highly metamorphosed materials of clastic origin, while others are regarded as foliated eruptives. As it is not possible, except in limiterl areas, to separate these rocks on the map, they are necessarily treated together.

The rocks of clastic origin are in nearly all cases the most ancient. The age of the areas of irruptive rocks is not known definitely, but many of them are very ancient, as fragments from them are included in the conglomerates of the Huronian. Others closely resemble the basic irruptives found cutting the Cambrian strata, und possibly are newer than that bedded series. These basic irruptives are in turn cut by later intrusions of granite, so that if the former are post-Cambrian some of the latter may be high up in Palreozoic tine. Where the age of these rocks can be determined by their intrusion into the bedded series of the Hurouian or Cambrian, they have been sejarated from the rest of the complex, and the remainder grouped under the name Laurentian until more evidence is obtained as to their exact age. It naay be taken for granted, however, that by far the greater portion of the irruptive rocks included in the Laurentian are extremely ancient, and that the areas of those supposed to be post-Cambrian are unimportant compared with the areas of rocks long antedating that formation.

Huronian. L'nder the name Huronian are included several widely separated areas of clastic and volcanic rocks, together with many basic eruptives ; these are represented by various schists, conglomerates, breccias, diorites and other rocks more or less interfolded with the Laurentian.

Caubrian.

The Cambrian rocks rest unconformably upon the Laurentian and Huronian, and are made up of bedded sandstones, argillites, shales and limestones, along with bedded traps and other basic intrusive or volcanic rocks. More detniled descriptions of the Huronian and Cambrian rocks are given under their respcctive headings.

Great lapse of time between Cambritil.

The Laurentian and Huronian gneisses nnd schists are intensely folded. This folding took place long previous to the deposition of the sedimentury beds of Cambrian age; and a sufficiently long time had elapsed between the period of folding and the Cambrian subinergence, to allow for great removal of material by denudation and for the main sculpturing of the peninsula. The Cambrian rocks are found flatbedded in the valley of Hamilton Inlet, and extend fifty miles up the Hamilton River; they are also found resting almost undisturbed in the great basins of Mistassini and Michikamau lakes. These examples 


\section{APPENDIX I:}

List of Mavialia of the Labrador Peningula, with Short Notes on tileir Distribution, Etc., BY A. P. Low.

The following notes on the habits and range of the mammalia of Labrador, as far as refers to the interior, are largely the results of observations and information obtained during the recent explorations :-

Lynx Canadensis, Desmarest (Canada Lynx, Mountain Cat).-The lynx is commonly found within the wooded area, from the Atlantic coast to Hudson Bay. During the winter of 1893 , mari' skins were taken in the valley of the Hamilton River. The number is said by the Indians and traders to vary with that of the rabbits which form the natural food of the lynx. When the rabbits are dying off after seasons of plenty, the Indians all say that the lynx does not breed, and only when the rabbits are again becoming plentiful do they again produce young. These animals are generally caught in dead-falls placed at the mouths of hollow logs.

Canis lupus, Linn. (Wolf). - The wolf is seldom met with in the southern regions since the extermination of the curibou there. It is now found only in the barren and semi-barren lands, where the caribou are still plentiful. A wolf was seen at the post at Northwest River, and a single skin was seen in the possession of an Indian on the upper Hamilton River; the animal had been shot near Lake Michikamau. On the Hudson Bay coast, wolves were formerly plentiful, but of late years are quite rare.

Cunis lupus, var. albus.-The White or Arctic Wolf is occasionally taken in the barren grounds, but does not appear to enter the timbered regions of the interior.

Canis familiaris, Say.-The Eskimo Dog is common along the coast everywhere, but south of Sandwich Bay the breed is much mixed. This animal plays an important part along the coasts, being used in the place of horses, or other animals for hauling. The methods of attaching the dogs to the sleds is different from that employed in the west, each dog having an independent trace, so arranged in length, that when the dogs are in line each one falls in behind another. The number of dogs in a team varies from four to thirteen. They are extensively used by the Eskimo and resident whites in 
travelling about the coast, and also for hauling wood, water and other loads. On ordinary 'roads' each dog will haul about 100 pounds, but when travelling on the crust, in the spring time, the load can easily be doubled or trebled.

Vulpes vulgaris, Fleming (Red, Cross, Silver and Black Fox).-These different animals are only colour varieties of the same species. On the Moose River, in 1887, the writer found a litter containing seven kits; of these two were red, three were cross and the remaining two black or silver-thus showing that the colour of foxes no more constitutes varieties than does the difference of colour in a litter of kittens of the common cat. There appears to be a greater proportion of dark-coloured foxes in the northern region than in the southern. The fox is found throughout Labrador from the St. Lawrence to Hudson Strait, where it is taken in the barrens and along the coast by the Eskimo. Most of the skins are taken before Christmas, as the fur becomes poor early in the spring.

Vulpes lagopus, Linn. (Arctic Fox, White Fox) is found most abundantly in the barren grounds. It is taken rarely south of Lake Michikamau or Nichicun. Along the seaboard the white fox ranges farther south, descending to the southern part of James Bay, and on the Atlantic coast being plentiful about Hamilton Inlet, but more rare southward to near the Strait of Belle Isle. Most of the foxes along the southern Atlantic coasts are said to he migrants from the northern coasts, and they are rarely caught south of Hrmilton Inlet before that body of water is frozen over. The blue fox (var. fuliginosus) is much less abundant than the white, with which it is found. It is very rare along the southern half of the Atlantic coast.

Mustela Americana, Turton (Sable, Pine Marten).-The marten is one of the most abundant and valuable fur-bearing animals of Labrador. Its northern range is practically limited to the southern boundary of the semi-barrens, and it is found only in the wooded stretches of the river-valleys north of this line; north of the Big and Hamilton rivers, it is rarely found. The largest and darkest skins are taken along the edge of its northern limits, and on this account the skins bought at Fort George, Nichicun, Fort Chimo and Northwest River are much more valuable than those procured at the southern posts. The marten hunt is made after the smaller lakes set fast until December, and again during the months of March and April, after which the skins become poor.

Mustela Pennantii, Erxleben (Fisher, Pekan).-This animal only rarely enters the south-west limits of ...abrador, not being known to occur east of Mingan, or north of Mistassini. 
Putorius vulgaris, Linn. (Weasel).-Common everywhere south of the tree limit.

Putorius ermineus, Linn. (Ermine).-Common everywhere throughout the wooded regions.

P'utorius vison, Brisson (Mink).-The mink is limited to the southern part of Labrador, and is only rarely found north of the East Main and Hamilton rivers. Not a single specimen was seen on the upper Hamilton River during the summer of 1894, and the Indians of that locality report it as rare. It is common on the lower river and about Hamilton Inlet. Several specimens were taken on the upper East Main River, but it is rare about Nichicun.

Gulo luscus (Linn.) Sabine (Wolverine, Carcajou).-Abundant throughout Labrador, especially in the northern portions, where it is taken by the Eskimo as far north as Hudson Strait. This animal is the personification of the devil among the Indians, owing to its cunning and destructive habits. Every Indian has wonderful stories to relate about the ferocity and intelligence of the wolverine. No câche of provisions or outfit is safe from the attacks of these animals, unless huilt up from the ground on high posts, in such a manner that the floors project and prevent the animals from reaching the sides or top. When a wolverine breaks into a câche, it not only eats the provisions, but breaks up and destroys other articles not fit for food. A wolverine in the vicinity of an Indian's hunting grounds, proves a very disagreeable neighbour, from its habits of following the hunter's tracks and either springing his traps and removing the bait, or else devouring the martens and other animals already caught. The wolverine is seldom caught itself, as its cunning is sufficient, after it has lost a few claws in the traps, not to put its feet in the set traps without first springing them by moving them about. When caught, they frequently gnaw off their foot above the trap and leave it, at other times they depart, taking trap and chain with them. In the fall of 1893 , a wolverine carried away a trap from the Northwest River, and was taken a few days later in another trap on the Hamilton River, some thirty miles away from the place where it had picked up the first trap. The reason it was taken in the second trap, was because it could not obtain food while dragging the trap and chain through the bush, so, being reduced to starvation and hampered by the trap attached to its front leg, it was not able to spring the second one without being caught.

Mephitis mephitica, Shaw (Skunk).-Stearns says that it is rarely seen on the southern coast. 
Lutra Canadensis, Turton (Otter).-The otter is common throughout the wooded region and ranges northward into the barren grounds. The skins taken in the northern regions have the darkest and most glessy fur. Very abundant on the upper Hamilton River, especially in the vicinity of the Grand Falls, where a number of Indian families congregate in the spring to hunt it.

Ursus arctos, Richardson (Barren-ground Bear).--There is no doubt that this species is found in the barrens of Labrador, as skins are brought in at intervals to Fort Chimo, and the Nascaupee Indians have numerous tales of its size and ferocity.

Ursus Americanus, Pallas (Black Bear).-The wooded country is the northern limit of this slecies, and it is most abundant in the southern regions in the burnt districts. Specimens were seen on the East Main River and about the Grand Falls on the Hamilten River. About Lake Winokapau and the lower Hamilton River bears are numerous. At Cambrian Lake, on the Koksoak River, the tracks of a large bear were seen along the shores, but it is not known whether these were those of a black bear or a barren-ground bear.

Thalassarctos maritimus, Iinn (Polar Bear).-This species is as a rule confined to the coast and rarely travels inland, except to produce its young. At such time it is met with from twenty-five to fifty miles from the const. On the Atlantic coast it is occasionally found as far south as the Strait of Belle Isle, whither it is carried from the north on ice floes. North of Hamilton Inlet, it is frequently met with along the coast and on the islands, being common about Cape Chidley and along Hudson Strait. During the winter of 1894 the tracks of three white bears were seen close to Northwest River, at the head of Hamilton Inlet, and a few specimens have been killed in that locality. In Hudson Bay, the white bear ranges southward to Charleton Island, near the south end of James Bay, in latitude 52.

Odobaenus rosmarus, Malmgren. (Walrus).-This species, once common along the entire Labrador coast and the Gulf of St. Lawrence, is now found only on the Atlantic coast about and to the northward of Nachvak. It is common at all seasons in Hudson Strait, and along the northern Hudson Bay coast. Large numbers are killed by the Eskimo on the chains of outer islands which stretch southward to opposite Little Whale River off that coast.

Phoca vitulina, Linn. (Harbour Seal, Fresh-water Seal).-Common to the coast and low parts of the rivers all round Labrador. There are two or three large lakes inland near the head of the Stillwater Branch of the Koksoak River, but probably drained by the Nastapoka 
River into Hudson Bay, where seals are reported by the Indians as plentiful. Another large lake inhabited by seals, is situated at the head of the north branch of the Northwest River, which flows into Hamilton Inlet. Skins in possession of the Indians, taken from these lakes, show that the s'als belong to this species. According to the Indians, these aumials never leave the lakes, and consequently have acquired a fresh-water habit.

Phoca foetida, Fabricius (Ringed Seal).-Along the whole Labrador coast. Commonest species in the Hudson Strait, and the principal food of the Eskimo.-(Tyrrell.)

Phoca Groenlandica, Fabricius (Harp Seal).-Very abundant along Labrador coast. Common on south shore of Hudson Strait. Common in Huclson Bay.

Erignathus barbatus, Fabricius (Bearded Seal, Square-Hipper). - Rare on the St. Lawrence and southern Labrador coasts. Common about Nachvak, where the dog traces made from this skin are obtained for the southern Hudson's Bay Company's posts. A large specimen was seen at the head of tide, some sixty miles above the mouth of the Koksoak River. Common in Hudson Strait and Hudson Bay. Numbers seen about the Twin Islands in James Bay. Specimen obtained at the mouth of Muose River by Dr. R. Bell.

Halichcerus grypus, Fabricius (Gray Seal).-Rare along Atlantic coast, Hudson Strait and Hudson Bay.

Cystophora cristata, Erxleben (Hooded Seal).-Not common along the coasts of Labrador.

Delphinopterus catodon, Linn. (White Porpoise, White Whale).Found every where along the coasts of the Labrador Peninsula from the St. Lawrence to the southern extremity of Hudson Bay. Fisheries for these animals are established in the mouths of the Koksoak, Leaf and Whnle rivers flowing into Ungava Bay, and were formerly calried on at Great and Little Whale rivers on Hudson Bay. The whales are driven, as they ascend the river at high tide, into ponds inclosed by strong nets, and when the tide $g$ es out they are either speared or shot in the shallow water.

Monodon monoceros, Linn. (Narwhal).-The "horns" of these animals are frequently brought to the Hudson's Bay posts by Eskimo from Hudson Strait and the north part of Hudson Bay.

Alce Americanus, Jardine (Moose).-It is very doubtful if this species enters the south-west limits of Labrador from the head-waters of the Ottawa River, where it is found abundantly. 
Raugifer caribou, Linn. (Woodland Caribou).-Within the past twenty-five yeurs the woodland caribou was plentiful throughout the southern wooded region, but now is practically exterminated on the southern watershed, being met only in small numbers about the heads of the rivers flowing into the eastern part of the Gulf of $\mathrm{St}$. Lawrence. In 1892, along the route from Lake St. John to Mistassini, and from there to the mouth of the East Main River, not a single deer track was seen. In 1885 , the last herd of seven caribou was killed in the vicinity of Lake Mistassini. A few woodland caribou are annually killed about the head-water's of the East Main River and Nichicun post. On the upper Hamilton River this species is still met with in small bands, but, according to the Indians the numbers at present killed are only a small percentage of the numbers annually slaughtered a few years past. This extermination of the caribou is very detrimental to the interior Indians, who in former times depended largely upon them both for food and clothing. Notwithstanding the quantity of flour now brought.inland, and the fish caught and preserved for winter use, cases of starvation are of annual occurrence from the lack of animal food in place of the deer meat. In 1892, a deserted camp where a dozen persons had died of starvation two years previously, was passed on the East Main River. The survivors-a woman and a boy-told the usual tale of failure to find deer and consequent starvation. There appears to be no remedy for this except the abandonment of the interior by a large proportion of the Indians, with the total suppression of caribou hunting for a number of years. This is probably not practicable, and the Indians of the interior will consequently, it is feared, continue to die off.

The astonishing rate at which the fur-bearing and other animals multiply when undisturbed, was noted along the East Main River, where, owing to tise death of Indians above mentioned, no hunt had been made for two years-and in that short interval the beavers hed overstocked the small streans, and were consmon all along the main river.

Rangifer Groenlandicus, Linn. (Barren-ground Caribou,"Reindeer"). -.This species ranges in immense herds over the barren and semi-barren grounds. On the Atlantic coast, caribou of this variety are found south to the Mealy Mountains, a high barren range between Hamilton Inlet and Sandwich Bay. To the northward they are more or less common and at certain seasons of the year very plentiful about Davis Inlet and Nain. On the Hudson Bay coast they were formerly very abundant as far soutl as Cape Jones or the mouth of James Bay, but of late years they are found only in small numbers north of Great Whale River. 
From information obtained from the Nascaupee Indians and others, the reindeer is believed to spend the summer season on the barren highlands near the coast, where the strong breezes keep down the pest of tlies. In the autumn they migrate inland and southward into the semi-barrens, returning to the true barrens again in the wonths of April and May. In the northern part of the peninsula there appear to be three distinct herds, one on the Atlantic coast, that passes the summer on the highlands hetween Nachvak and Nain; a second, which crosses the lower part of the Koksoak River and summers on the west side of the Ungava Bay and Hudson Strait; and $\boldsymbol{n}$ third, which pass's northward from the vicinity of Richmond Gulf and Clearwater Lake, and summers along the highlands of the north-east const of Hudson Bay. "Of late years, this last herd has become very sinall, and many of the Indians who lived on it have migrated from Hudson Bay to Fort Chimo, while the second herd was undiminished. The first herd supports the Indians living on the George River, and almost all from the Hamilton River. The principal hunt is made during the fall migration, when the bucks are fat and have not yet mated with the females. The Indians congregate along the George River, about a hundred miles beyond Lake Michikamau. They spread out along the river and await the crossing of the bands of deer on their way from the coust to the wooded country. As soon as a large body begins to cross, signals of smoke are inade, and the Indians soon congregate and kill great numbers from their canoes by spearing them while in the water. The season for crossing lasts from ten to fifteen days. Much of the flesh is smoked for winter use, while the skins are preserved and dressed, either for clothing and other purposes or for sale. In the spring the deer migrate in small bands and are not so easily taken, as the snow and ice are then beginning to melt and they have to be killed by shooting after a chase. The migration of the second band is similar to that already described, except that during the fall migration small herds are continually crossing back wards and forwards along the river. Wide paths, caused by a single passage of the deer, were met with along the Koksoak River as far south as Cambrian Lake, and smaller paths as far as Lake Kaniapiskau, where a small number of the reindeer appear to remain throughout the summer. $A$ couple of large paths were found on the Ashuanipi branch of the Hamilton River, and in the spring a number of tracks, made by small herds, were encountered below the Grand Falls. Periodically, the reindeer omit to return to the wooded areas from the barrens, and when this happens the Indians depending on them are left in a most lamentable condition, being largely without food and clothing. Many die of starvation in consequence unless outside aid ia given. The 
death of over 150 persons along the Koksoak River during the winter of 1893 , is but one of several such calamities which have happened during the last fifty years. In the evidence given before the committee of the Hudson's Bay Company, 1851, a letter was read from Wm. Kennedy as follows: "Starvation has, I learn, committed great havoc among our old friends the Nascopies, numbers of whom met their death from want last winter; whole camps of them were found dead, without one survivor to tell the tale of their sufferings."

Ovibos moschatus, Zimmermann (Musk Ox.) -There is no evidence to show that the musk ox was ever found in Labrador.

Vespertilio lucifugus, Leconte (Blunt-nosed Bat).-A small bat is common in the southern portion of the peninsula, having been seen on the Hamilton River and at Lake Mistassini, and it is supposed to be referable to this species.

Vespertilio subulatus, Say, is reported by Stearns from Natashquan.

Sorex $p$ "sonatus, Geoffroy St. Hilaire (S. Cooperi, Baird).-This small shrew was obtained at Sand wich Bay.

Sciuropterns volucella, Pallas, var. Hudsonius, Gmel. (Northern Flying Squirrel.-Common in the valley of the lower Hamilton River and about the head of Hamilton Inlet. Found at St. Augustine (Stearns).

Sciurus Hudsonius, Pallas (Red Squirrel).-Found throughout the southern wooded region as far north as the East Main River, and to the westward; on the Hamilton River from its mouth to Sandgirt Lake, and southward on the Attikonak Branch, but not along the Ashuanipi Branch.

Arctomys monax, Linn. (Woodchuck, Ground-hog).-Common in the country between Lake St. John and the East Main River, and on the Romaine River. Not seen on the Hamilton River, but said to be found about the head of Hamilton Inlet. "Common at Mingan, growing scarce towards Bonne Espérance" (Stearns).

Castor fiber, Linn. (Beaver).-Common in the wooded region and extending into the semi-barrens where food is found. On the Hudson Bay coast, rure north of Big River. In 1987 a specimen was killed in Richmond Gulf, latitude $56^{\circ}$. Charleton Island, in James Bay, was well-stocked with beaver introduced by the Hudson's Bay Company, but they were totally exterminated by wandering Eskimo in 1890 . As before stated, beaver are very plentiful on the Lower East Main River. 'About Nichicun they are now more plentiful than formerly. 
Common about the Lower Hanilton River and upwards to Sandgirt Lake, becoming very rare to the northwurd towards Lake Michikauau.

I/esperomys leucopus, Rafinesque (White-foote r Deer MLouse).Common at Northwest River, Hudson's Bay post.

Arvicola viparius, Ord.-Specinen taken on Upper Hamilton River near Lake Petitsikapau. The Indians report a spaller species as not rure in the interior wooded country.

Cuniculus torquatus, Pallus. (Hudson Bay Lemming).-Common throughout the harren ground and southward to about latitude $54^{\circ}$. Specimen ohtained trom Lake Michikamau.

Zapus //ulsonius, (Zimmermann) Coues, (Jumping Mousc).-Not rure in the wooder region. Specimens taken at the mouth of the Hamilton River, near the Grand Falls, and on the Romaine River portages. The Indians who saw these specimens say that thore is a much smuller species found in the interior, which closely resembles the larger, except in size.

Fiber zibethicus, Linn. (Muskrat).-Common in the southern-wooded region, but rare along the Upper Hamilton River.

Erethizon dorsatus, Linn. (Canada Porcupine),-Banges from the St. Lawrence northward into the semi-bar'ens. Very plentiful along the Hamilton River, where it is largely used for food by the Indiaus: Common at Hamilton Inlet, and northward to Hopedale. Traces seen alongr the Great Whale River, and also on the Koksoak River, alove Cambrian Lake.

Lepres timidhes, Linn., var. arcticus, Leach. (Polar Haro).-Confined to the barren and semi-barren lnnds of Labiador. On the Hudson Bay coast a few are taken about Great Whale liver. On the Atlantic they occur southward as far as Hamilton Inlet. A few are killed about Lake Michikamau.

Lepus dmericanus, Erxleben (Hure, "Rabbit").-Found throughout the wooded region. Like the western rabbit, it is visited periodically with an infectious throat-disease, which about once in five years practically exterminates the animal. The disease npparently travels from the west towards the enst and takes about two years to cross Labrador. The rabbit is largely used for food by the Indians, but is not sustaining, and they all say that on a diet of rabbits alone they rapidly become weak and unfit for work. 



\section{APPENDIX II.}

\section{List of Birds of tie Interior of tile Labrador Peningula}

Urinator imber, Gunn. (Loon). - Common throughout the interior; breeds.

Urinator lumme, Gunn. (Red-throated Loon).-Common on upper Hamilton River and Koksoak River; breeds.

Urinator arcticus, Linn.-Been June 3rd at Lake Mistassini; not common.

Uria troile, Linn. (Murre),-Common in open water of Hamilton Inlet until January 20th, 1894.

Alle alle, Linn. (Dovekie). - Very common in Hamilton Inlet until January 20tls, 1894. Numbers of this and the preceding found frozen in bushes along the edge of the open water.

Guvia alba, Gunn. (Ivory Gull).--Specimen obtained at Rigolet, where it was shot during the winter; seen at Northwest River late in December after the inlet was frozen; not common.

Larus glaucus, Brunn. (Glaucous Gull).-Common throughout the interior; seen May 19th; eggs June 14th.

Larus Delawarensis, Ord.-Nests at Mistassini Lake; seen June 11 th.

Sterna Forsteri, Nutt. (Forster's Tern),-Common throughout interior ; seen June 13th, Hanilton River, June ist, Mistassini.

Mcrganser Americanus, Cass. (American Merganser).-Common throughout interior; seen May 28th; eggs June 25th.

Merganser serrator, Jinn. (Red-breasted Sheldrake).-Abundant throughout the interior; seen May 28th; eggs June 25th.

Anas abscura, Gmel. (Black Duck).-Not common throughout the interior; seen May 1st; eggs May 23rd.

Glaucionetta clangula Americana, Bp. (American Golden-eye).-A few flocks seen on upper Hamilton River during June; seen at Mistassini May 3rd.

Somateria smectabilis, Linn. (King Eider).-One specimen killed at Lake Mistassini.

Oidemia Americana, Sw. and Rich. (American Scoter).-Common on Hamilton River, May and June, in migration; seen May 26th. 
Oidrmia perspicillata, T.iun (Surf Duck). - Common on Hunilton River during migration, May and June; seen May 26th.

Branta C'aruulensis, Linu. (Cnnada Goose).-Dreeds in uns'shes throughout the northern interior, and is seen nlong the river's with young hroods about July lst; seen at Mistnssini May 2nd, at. Grund Falls, Hanilton River, Mny 4th. From the journals of the Hudson's Bay Company, the avorage date of first arrival at Lake Winokupau and Nortliwest River, is May l0th; neveral large broods seen on Burnt Lukes, Romaine Rivor; not common at Lake Mistassini, but nbundant on East Mnin River-especinlly on lower part, where the river is cut out of clays, with good bottom-Innds; breeds in large numbers on the islands of James Bay.

Brautu bernicla, linn.(Brant).- Vory rare in the interior; one siek killed at Mistnssini July 2nd. If these birdt cross Labirulor in their northern migrntion, they fly high nud only rurely rest, us tho Indinns, who know them well on the St. Lawrence eonst, report them very rnre in the interior.

Nyrticora: nyeticorax nervius, Allen (Black-erowned Night-Heron). -Single specimen at Lake Mistassini, August bth.

I'haluropus lobatus, Linn. (Northern Phalarope), -Seen on upper Hamilton River, June 13th. Not eommon.

(iallinago delicata, Ord. (Wilson's Snipn).-Male henrd nnd seen nt Lake Petitsikapau, Hunilton River, June 28th.

I'ringu minutilla, Vieill. (Lenst Sundpiper).-Common nbout Upper Hamilton River. Breeds.

Totamus melanolencus, Gmel. (Greater. Yellow Leers).-Met with ocensionally throughout the interior Breeds. Seen Miny 31st.

Tolam stavipes, Gmel. (Yellow Legs).- Seen only nfter August lst, on Hamilton River and at Mistassini.

Totanus solitarius, Wils. (Solitary Sandpiper).--Common throughout the interior, especially south of Intitudo $54^{\circ}$. Breeds. Seen Mrny 27tl. Egrgs June 19th.

Actitis macnlaria, Linn. (Spotted Sandpiper).-Common nlong the upper Hamilton River. Seen Mny 27th. Eggs June 20th.

.Egialitis semipalmata, Cabnn. (Semipalmated Plover).-Common on Upper Hamilton River. Seen June 16th. Breeds.

Dendragapns Canadensis, Linn. (Cannda Grouse, Spruce Partridge).-Common throughout wooded and in the semi-barrens. Eggs June 1st. 
Bonasa umbellus togata, Linn. (Ruffed Grouse, "Partridge." Birch Partridge).-Common at Mistassini. Not rare at mouth of Hauilton liver. Not found on Upper Hamilton Miver.

Layopus lagopus, Linn (Willow Ptarmignn),-Common through. out the winter. Breeds on Upper Hamilten River. Eggs June 25th.

Lagopus rupestris, Gm. (llock Pturmignn).-Common in valley of Hamilton River during winter. Lenves for northward about April 15 th.

bitopistes migratorius, Linn. (Passenger Pigeon).-Very rare. Eggs obtained at Fort George, 1887.

Accipiter atricapillus, Wils. (American Goshawk).-Specimen killed near Cambrian Lake, Koksoak River; also on lower Hamilton River: Not common.

Aquila chrysaeto, Linn. (Colden Eagle).-13reeds at herl of Lake Michikamau. Seen in severnl places along upper Hnmilton River.

Ilalidetus leucocephalues, Linn. (Bald Eingle). - A pair seen on Hamilton River below Grand Falls, April 28th. White heads dis" tinctly seen.

Falco rusticolus obsoletus, Gmel. (Labrador Gyrfalcon).-Specimen shot ut Cape Chidley.

Falco peregriuıs anatım, Bon. (Duck Hawk). - Not uncommon throughout the interior.

Pandion halidetus Carolinensis, Gm. (Osprey).-Common throughout southern interior, to lnt. 54. Seen May 27th. Eggs June 12th. Nest on top of large white spruce.

Asio accipitrinus, Pall. (Short-eared Owl).-Seen on Upper Hamilton and Romaine rivers.

Nyclale Acadica, Gmel. (Saw-whet Owl).-Specimen shot near Lake Mistassini.

Bubo Virginirenus saturatus, Ridgw. (Dusky Horned Owl).-Common alout Northwest River during winter. Common in the interior.

Sumia ulula caparoch, Mïll. (American Hawk Ow]).-Seen several times on U Pper Hamilton River.

Ceryle alcyon, Linn. (Belted Kingfisher).-Wns not found north of the vicinity of the Grand Falls, Hanilton River. Common on Romaine River and at Lake Mistassini. Seen May 30th.

Dryobates villosus leucomelas, Bodd. (Hairy Woodpecker).-Whot in valley of Hamilton River in March. Not rare.

Dryobates pubescens, Linn. (Downy Woodpecker).-Common on Hamilton River throughout the year. 
Picoides arcticus, Swains. (Black-backed Threo-toed Woodpecker). -Common along Lower Hamiltnn River.

Colaptes auratus, Linn. (Yellow-shafted Flicker).--Single specimen seen near Grand Falls, Hamilton River, 30th May.

Chordeiles Virginianus, Gmel. (Night-hawk).-Very rare on Upper Hamilton River. Single specimen seen near the Grand Falls, May 31st. Cummon at Mistassini and along Romaine River.

Empidonax flaviventris, Baird. (Yellow-bellied Fly Catcher).-Conmon at Lake Mistassini. Not seen at Hamilton River.

Otocoris alpestris. Linn. (Horned Lark).-Common on barrens of Upper Hamilton River and about Lake Michikamuu._Eggs June 19th.

Perisoreus Canadensis, Linn. (Canada Jay).--Very common throughout the interior. Nest with four eggs taken at Rigolet March 24th, 1894 ; and another at North-west River, with three eggs, about the same date. Young able to fly from nest on May 18th, at Grand Falls, Hamilton River.

Perisoreus Canadensis nigricapillus, Ridgw. (Labrador Jay).Abundant throughotit is thern interior.

Corvus corax principalis, Ridgw.--Common throughout the interior. Resident.

Molothrus ater, Gray. (Cowbirl).-Common at Lake Mistassini.

Scolecophagus Carolinus, Mlïll. (Rusty Black Bird).-Common throughout the interior.

Pinicola enucleator, Linn. (Pine Grosbeak).-Common on the Upper Hanilton River. Male seen May 1st.

Loxia leucopter, Gmel. (White-winged Cross-bill).-Common on Hamilton River in March and April.

Acanthis linaria, Linn. (Common Redpoll).-Abundant about the Hamilton River.

Plectropisenax nivalis, Linn. (Snow Bunting).-Plentiful on Hamilton River in early spring.

Calcarius Lapponicus, Linn.(Lapland Longspur).-Common on Hamilton River in early spring.

Amnodramus Sandwichensis Savanna, Wils. (Savannah Sparrow). -Very common on upper Hamilton River. Eggs I Une 24th.

Zonotrichia Leucophrys, Forst. (White-Crowned Sparrow).- - Very common on upper Hamilton River. Seen May 16th. Eggs June 25th.

Zonotriclia albicollis, Gmel. (White-throated Sparrow).-Common at Lake Mistassini. Heard at Grand Falls, Hamilton River. Common on the Romaine River. 
Spizella monticola, Gmel. (Tree Sparrow).-Common everywhere in Labrador. Breeds in great numbers on upper Hamilton River. Seen May 31st; eggs June 21st.

Junco hyemalis, Linn. (Black Snow-bird).-Common at Lake Mistassini and upper Hamilton River. Seen Nay 29th. Eggs June 27th.

Melospiza fasciata, Scott (Song Sparrow).-Common at Lake Mistassini.

Tachycineta bicolor; Vieill. (White-bellied Swallow).-Common throughout the interior. Seen May 25th.

Ampelis cedrornm, Vieill. (Cedar Wax-wing).-Rare at Lake Mistassini.

Lanius borealis, Vieill. (Great Northern Shrike).-Common on Hamilton River; seen April 16tl.

Helminthophaga peregina, Wils. (Tennessee Warbler).-Not rare at Lake Mistassini.

Dendroica rstiva, Gmel. (Yellow Warbler).-Common at Lake Missassini ; seen near Grand Falls, Hamilton River, May 31st.

Dendroica coronata, Linn. (Myrtle Warbler).-Specimen from Grand Falls, Hamilton River, May 31 st.

Dendroica maculosa, Gmel. (Magnolia Warbler).-Not rare at Lake Mistassini.

Dendroica striata, Forst. (Black-poll Warbler).-Common on upper Hamilton River. Seen May 31st.

Seizrns Noveboracensis, Gmel. (Water Thrush).-Common about Grand Falls, Hamilton River. Seen May 31st.

Sylvania pusilla, Wils. (Black-capped Yellow Warbler).-Seen near Grand Falls, Hamilton River, May 31st. Not rare at Lake Mistassini.

l'arus Hudsonicus, Forst. (Hudsonian Chickadee).-Abundant on Hamilton River from April 1st.

Regulus satrapa, Licht. (Golden-crowned Kinglet).-Common on Hamilton River between Grand Falls und Sandy Lake; rare to northward; seen May 19 th.

Regulus calendula, Linn. (Ruby-crowned Kinglet).-Very common along Hamilton River between Grand Falls and Sandy Lake. Seen May 29th.

T'urdus nstulatus Surainsonii, Caban. (Olive-backed Thrush).-Very common along the upper Hamilton River. Seen May 16th. Eggs June 30th. 
$328 \mathrm{~L}$

I.ABRADOR PENINSULA.

Thurdus Aonalaschke Pallasii, Caban. (Hermit Thrush).-Not rare at Lake Mistassini.

Merula migratoria, Linn. (American Robin).-Abundant through. out the interior. Seen May 10th. Eggs June 13th. 


\section{APPENDIX III.}

\section{List of the principal Food fishes of the Iabrador Pexinsula, with Short Notes on their Distribution.}

Petromyzon (sp.)-A small Lamprey was taken on the Bersimis River a few miles below Lake Pipmaukin, 1884, adhering to a large brook trout.

Accipenser (sp.)-Aspecies of Sturgeon is very plentiful in the Rupert River, being taken in large quantities at Lake Nemiskau, where the Indians congregate and dry the fish during September. The fish here are usually under three feet in length. Also abundant in the river from Lake Nemiskau to its mouth. Common in the East Main River, from its mouth to Conglomerate Gorge. Also found in the lower part of the George River and in the Nottaway at Lake Obatogaman, near its heal.

Catostomus longirostrir, LeSueur (Long-nosed Sucker, Northern Sucker).-Common in rivers and lakes throughout the interior. The principal food of the Indians in many parts of Labrador.

Catostomus Forsterianus, Richardson. (Red Sucking Carp, Red Sucker).-This is usually regarded as a variety of the above, but Sir John Richardson gives it as a distinct species, and the fish found in Labrador is quite distinct in shape, size of scales and colour, from the tirst-named sucker. It is at least two weeks later on the spawning beds. Common throughout the interior. Preferred by the Indians for food to the gray sucker. Average weight of both species about 5 pounds.

Osmerus mordax (Mitchill), Gill. (American Smelt),-Common at the mouth of the Northwest River, Hamilton Inlet, where it is abundantly taken in November and the early part of December.

Coregonus clupeiformis (Mitchill), Milner (Common Whiteish).Found abundantly throughout the interior, in lakes and rivers. Largest fish taken in Lake Mistassini, 14 pounds weight. Average weight 3 or 4 pounds. A small species of whitefish closely resembling the common whitefish is caught in abundance in the shallow salt water along the east coast of James Bay. These fish ascend the rivers of James Bay during the autumn months along with sea trout.

Snimo salar, Linn. (Common Atlantic Salmon).-Abundant in the .ivers of the St. Lawrence and the Atlantic coasts and also in the rivers 
flowing into Ungava Bay. Reported by Dr. R. Bell, as taken by Eskimo at Stupart Bay, at the western side of Ungava Bay or Hudson Strait. The salmon enter the rivers of the St. Lawrence coast early in June, are taken in Hamilton Inlet in July, but do not ascend the Koksoak and other rivers of Ungava Bay until about the middle of August. From this there would appear to be some connection between the time at which the fish strike into the rivers and the temperature of the water along the coast, that to the north ward rising moro slowly than the southern waters; or else the fish follow northward along the coast and take at least two months to pass from the Strait of Belle Isle to Ungava Bay. There is no evidence, however, to show that the fish thus follow the coast. The time at which the salmon enter Ungava Bay from the Atlantic and the absence of this species from Hudson Bay, would seem to show that the waters of the western part of IIudson Strait do not rise sufficiently in temperature to allow the salmon to enter Hudson Bay in time to ascend its rivers before the spawning season, and this is the probable cause why no Atlantic salmon have been are found in its rivers.

The land-locked variety of $S$. salar, or ouinaniche, is found in Lake St. John and the tributaries of the Saguenay River, where it has free access to the sea, but as the same fish was found plentifully in both branches of the Hanilton River, above the Grand Falls with its sheer drop of 300 feei, it is certainly land-locked there. It is also common in the Koksoak River below Lake Kaniapiskau, above perpendicular falls of eighty fect and sixty feet. Common in Lake Michikamau or the head of the Northwest River. It is also reported by the Indians ns numerous in the upper George River, the Romaine River the Manicuagan and several other of the rivers flowing into the Gulf of St. Lawrence. It has not yet been reported from the rivers of the western watershed. Average weight of the fish caught, not above three pounds. The Indians report that the largest in the Hamilton River clo not exceed ten pounds in weight.

Salmo Hearnii, Richardson (Hearne's Salmon). - A small salmon, with bright red spots on its sides, is found along the northern east const of Hudson Bay, and probably belongs to this species. Its southern limit is a small river a few miles south of Cape Jones. It is taken in nets set in the salt water near Long Island, just north of Cape Jones, and also in some small streams flowing into Richmond Gulf. The Eskimo also report it common in some of the rivers north of Richmond Gulf.

Salvelinus namaycush (Walbaum), Goode (Great Lake Trout). - Very p'entiful in all the larger lakes of the interior northward to Hudson 
Strait. Very abundant in the lake-expansions of the Hamilton River and Lake Michikamar. Average weight ahout 8 pounds, but many taken more than 25 pounds in weight.

Salvelinus fontinalis (Mitchill), Gill and Jordan (Brook Trout).-This fish is abundant in many of the rivers and lakes of the Labrador Peninsula. Sea-run fish of this species are plentiful along the shores and lower parts of the rivers from the St. Lawrence to the southern part of James Bay. On the Atlantic coast and Ungava Bay, they are particularly plentiful and of large size. Along these coasts the mouth of every river swarms with trout during the late summer and autumn. The largest fish reported was taken at Nachvak and weighed fourteen pounds. In the Koksoak and George rivers, the average weight of the sea-run trout is about seven pounds. In Hamilton Inlet, there is less change in the sea-run fish than along the const. At Northwest River the fish are small and do not average over one pound in weight. Here they were freely taken with a $\mathrm{fly}$, up to the middle of December, when the mouth of the river was frozen over. In the mouth of the Hamilton River, sea-run trout average abont three pounds in weight.

In James Bay, the trout taken along the coast and in the lower parts of the rivers are generally small and do not exceed two pounds in average weight. Between the lowest falls and the upper waters of the western rivers, brook trout are rarely taken, but in the northern, eastern and many of the southern rivers they are abundant along their entire length.

In the Koksoak River, for a few miles below Lake Kaniapiskau, large trout were abundant, but lower down they became smaller, until the sea-run fish were met with. On the Hamilton River, below the Grand Falls, the trout do not average over one pound in weight. Above the falls, the fish are much larger, and average more than three pounds in weight, while fish of five pounds and seven pounds are common. On the Romaine River, no trout were taken until the Burnt Lakes were passed, when they became plentiful, though small. Outside of the rivers and small streams, this species is found abundantly in most of the numberless lakes throughout the interior. Two varieties are met with everywhere; one has pink flesh, the othel yellow, the former having the finest flavour.

Exoxtheins, Linn. (Pike).-'This tish is found abundan'ly throughout the interior in the lakes and quiet-flowing streams; common on the livers of the southern, eastern and western watersheds; not so abundant in the Koksoak River. It varies in weight from tw $\mathrm{s}$ to fifteen pounds. 
Anguilla (Sp).-CTh3 Indians report eels as common in the upper Romaine River.

Stizostediun vitreum(Mitchill), Jor.lan and Copeland(Wall-eyed Pike, Doré, "Perch" of the Hudson Bay Co)._Common in the southern rivers flowing into Lake St. John and to the westward, also in the Rupert and East Main rivers of the western watershed. Rare in the Betsiamites River, and not found east of that stream, being unknown to the Indians of Mingan. Not found in the Big River, or streams to the north of it, nor in the rivers of the eastern or northern water'sheds. Average weight, three pounds.

Lota maculosa (Le Sueur), Cuvier and Valenciennes (Ling, LaLoche, Maria).-Common in all the deep lakes throughout the interior. An important source of food for the Indians, owing to its taking bait freely during the winter months, when other fish cannot be car aht. Weight, $t_{\text {wo }}$ pounds to fifteen pounds.

Gudus callarias, Linn. (Common Cod-fish).-Plentiful along the St. Lawrence and Atluntic coasts to Cape Chidley. also along the east shore of Ungava Bay to the mouth of George River. The follow-

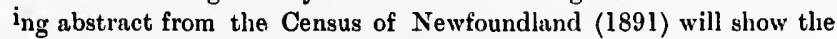
extent and value of the cod-fishing of the Atlantic coast :-

" 10,478 men, 2081 women and 828 childrin were employed in the fishery in 861 vessels, of which the tonnage amounted to 33,689 tons. The total catch of codfish amounted to 488,788 quintals." Fishing beyond Cape Uhidley, along the east coast of Ungava Bay, was not undertaken until 1893 , when a Newfoundland steamer was so successful that in 1894 two steamers and three schooners made successful catches in the neighbourhood of Port Burwell. The Eskimo report cod as being plentiful about the mouth of George River in the month of August. It is at present unknown whether this fish enters Hudson Bay, and it is a question which should speedily be settled by a properly equipped vessel, as valuable fisheries in the northern part of that great body of water nuay be lying idle for want of proper information concerning them. 


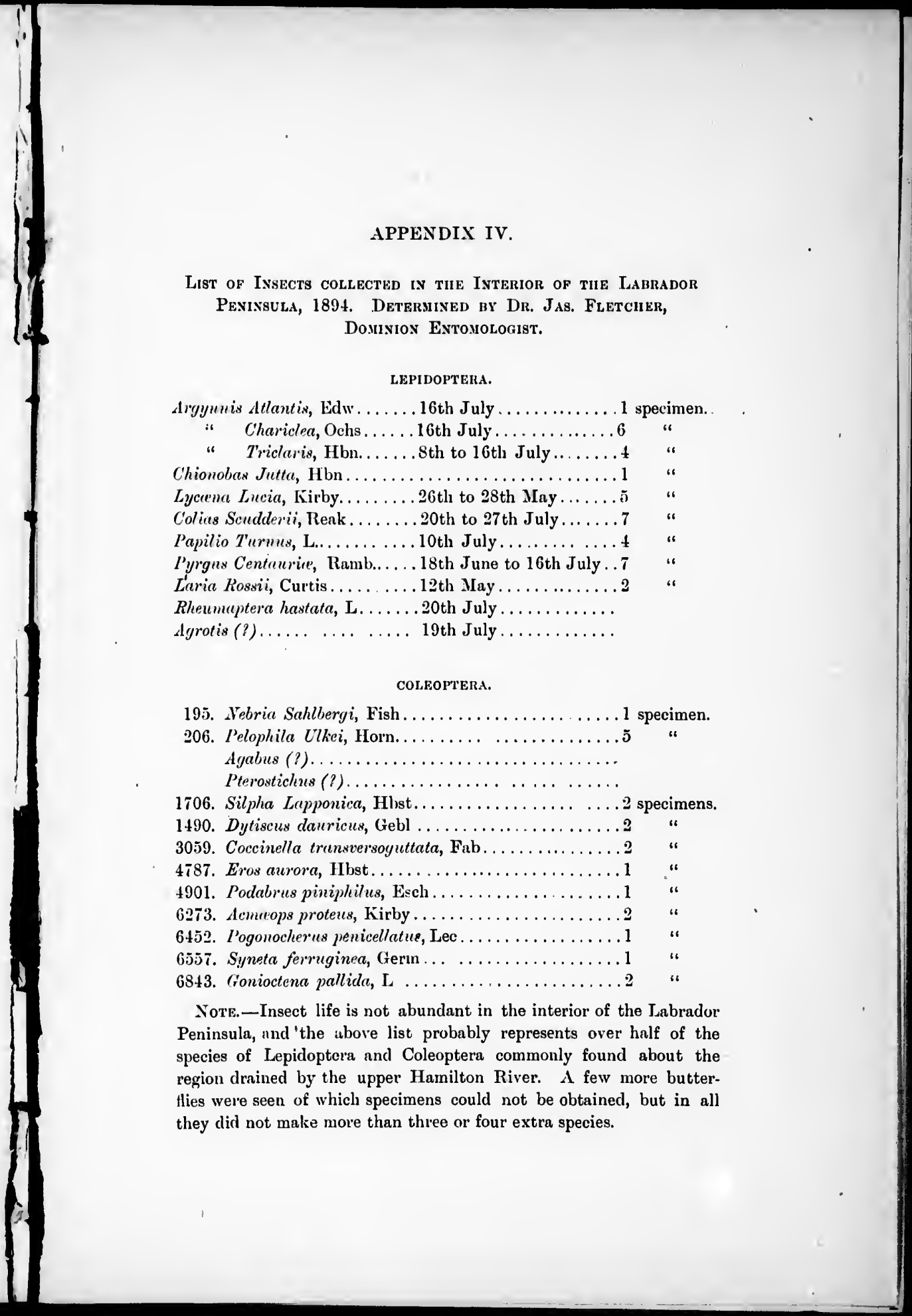




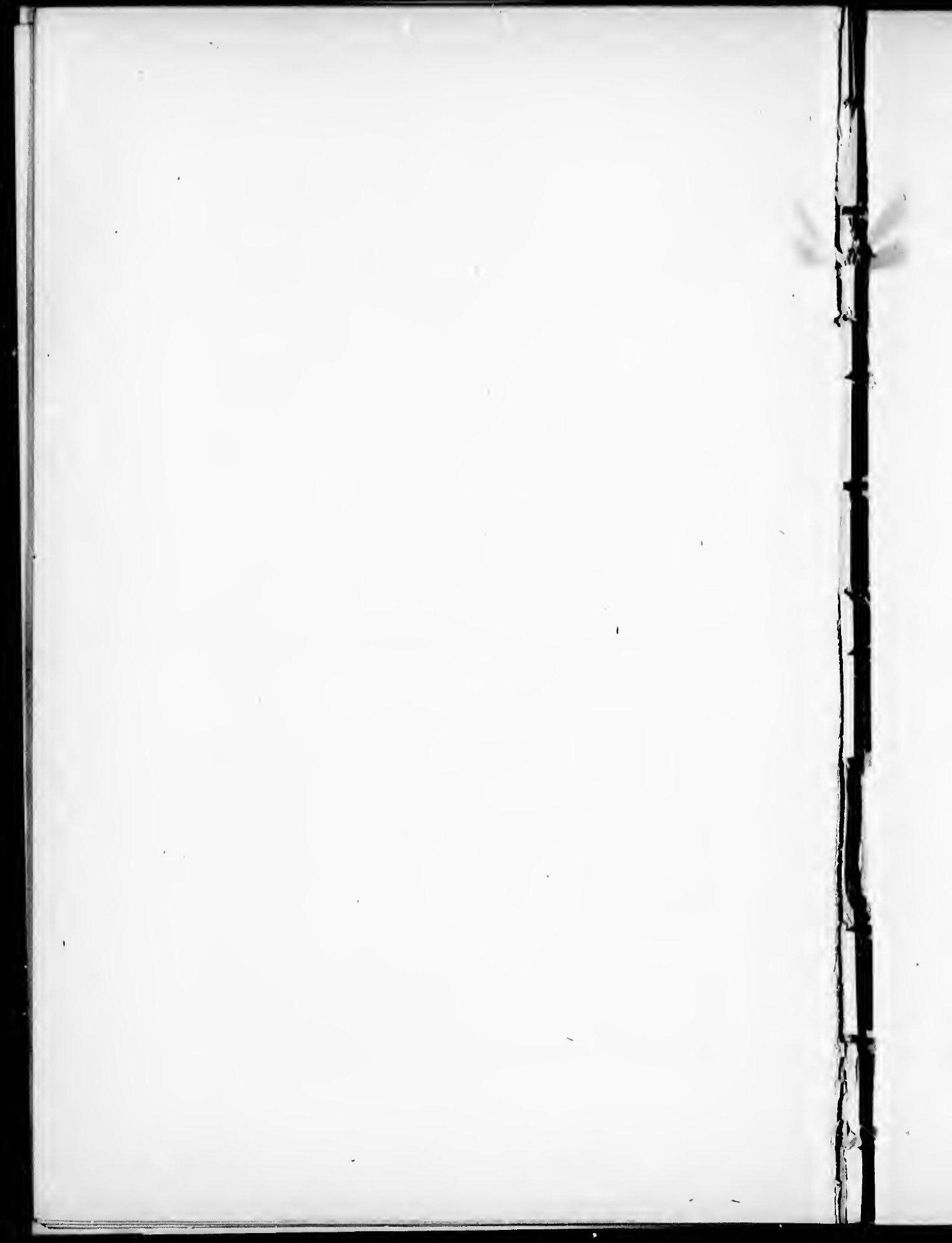




\title{
APPENDIX $V$.
}

\section{Notes oN tule Microscopic Structure of some Rocks from tile Ianrador Peningula.}

BY

\author{
W. F. F E R R I E R, B. A. Sc., F.G.S.,
}

Lithologist, (icoloyical Surrey of Cancula.

\section{INTRODUCTORY REMARKS.}

The following notes on a series of thirty-four rock specimens, collected by Mr. A. P. Low in the Labrador Peninsula, in 1893, 1894 and 1895 , are offered as a contribution to our knowledge of the petrography of that little-known country.

It must be understood, however, that the proportions in which the various rock types occur in the collection do not in any sen se represent the relative frequency of occurrence of these types in the field. Only such specimens as were of a doubtful character, or had some special points of interest attaching to them, were selected by Mr. Low for microscopic examination.

Of the'thirty-four specimens examined, sone fourteen are undoubted diabases and gabbros of varying degrees of freshness. Eight others, now mainly dioritic, have probably been derived from similar rocks by alteration. One specimen (23) was apparently originally a diorite. Three hornblende-schists or amphibolites $(4,16,17)$ bave been, without doubt, produced by the crushing and shearing of basic eruptives.

Three of the diabases $(32,33,34)$ have been already described by Mr. A. E. Barlow, ${ }^{*}$ and are of interest as containing decomposed porphyritic crystals of plagioclase very similar to the "Huronite" of Dr. Thompson. $\dagger$ Among the gneissic rocks the interesting hypersthene syenite $\mathrm{gn}$ iss (6) may be specially noted.

The granites, quartz porphyries and syenites are not nunıerous in th collection, the two former being represented by a single specimen each $(19,5)$, and the latter by two specimens $(6,21)$.

* On some Dykes containing Huronite. Ottawa Naturalist, vol. IX., No. 2, 1895 . + Thompson's Minernlogy, I., p. 384, 1836. 
The beatifully fresh felspar-free pyroxenite or hypersthenite (13) is worthy of specinl mention as an exvellent example of these rocks, which bave seldom been met with in Cunuda.

The white anorthosite (24) is a typical example of its cluss, und elosely resembles those described by Dr. Adums from the Suguenny and Morin arens of Norian rocks.

Rocks of elastie origin nre represented in the collection by a finegrained greywacke (9) which, in the lund specimen, night rendily be taken for an eruptive, and a much altered specimen (1) which inny possibly be an ash.rock.

The liternture of the subject is not very extensive, and thoso papers which enter into details regurding the rocks denl chiefly with the anorthosites.

A list of the principal papers and hooks which have appeared, taken, witl some additis, is and alterations, from Dr. Ada:... 's paper on the Norian rocks of Canada, ${ }^{*}$ is here appended :-

Adams, F. D.:-

Ueber das Norian oder Ober-Laurentian von Cunnda. Stuttgart, 1893 ; also translation of same in Canadian Record of Science, Vol. VI., 1895.

Barlow, A, ¿.:-

On some Dykes containing Huronite. Ottawn Naturalist, Vol, I.X., No. 2, 1895 .

Baddeley, Lieut. (F. H.):-

Geology of a portion of the Lubrador Const. Trans. Lit. and Hist. Soc. of Quebec, Vol. I., 18:9.

Bnyfield, Cupt. :-

Notes on the Geology of the North Const of the St. Lawrence. Truns. Geol. Soc., London, Vol. V., 1833.

Bell, Robert :-

Observations on Geology, Mineralogy, Zoology and Botany of the Labrndor Coast, Hudion's Bay and Strait. Ann. Rep., Geol. Surv. Canada, 1882-84.

The Labrador Peninsuln. The Scottish Gengraphical Magazine, Vol. XI., No. 7, 1895.

Cayley, Ed.:-

Up the River Moisie. Trans. Lit. and Hist. Soc. of Quebec, Vol. V, 1862.

*u ther das Norian oder Ober-Laurentian won Canadn, Stuttgart, 1893 : also translatir. Canadian Recorl of Science, vol. VI., 1815. 
Colien, E.:-

Dns Labrarlotit-fiihrende Gestein der Kiiste vou Lubrador. Neues Jahrb. für Min., 1885, I., p. 183.

Davies, W. H. A.:-

Notes on Esquimnux Bay and the surrounding Country. Trins. Lit. and Hist. Soc. of Quebee, Vol. IV., $18+3$.

Hind, H. Y.:-

Observations on Supposed Glncinl Drift in the Labrador Peninsu'a, etc. Q. J. G. S., Jnn., 1864.

Explorations in the Interior of the Labindor Peninsuln. London, 1863.

Jannasch, P.:-

Uober die Löslichkeit des Labradors von del' Puulinsel in Salzsïure. Neues Jahrb. fiir Min., 1884, II., p. 42.

Lieber, O. MI::-

Die amerikanische astronomische Expedition nach Labraclor, im Juli, 1800. Peterm. Mitth., 1861.

Low, A. P.:-

On the Mistnssini Expedition. Ann. Rep., Geol. Surv. Cannda, 1885, Part D.

The Recent Exploration of the Labrador Peninsula. Canudian Record of Scienee, Vol. VI., No. 3, 1894.

Paekard, A. S.:-

The Labrudor Coast. London, 1861.

Observations on the Glacial Phenomena of Labrador and Maine, etc. Mem. Boston Soc. Nat. Hist., Vol. I., 1865.

Observations on the Drift Phonomena of Labrador. Canadian Nuturalist (New Series), Vol. II., 1865.

The Labrador Coast. London, 1891.

Puyjalon, H. de :-

Report on the 'Yopper, etc., found to exist on the North Shore of the Gulf of St. Lawrence. Report of Com. of Crown Lands, Provinee of Quebec, 1883.

Report of Exploration for ninerals on North Shore of the Gulf of St. Lawrence. Report of Com. of Crown Lands, Provinee of Quebec, 1884.

These two reports contain references to the anorthosites, syenites and other roeks of the region.

Reichel, L. J.:-

Labrador, Bemerkungen iber Land and Leute. Peterm. Mitth 1863. 
IRichurdson, J.:-

The Geology of the Vicinity of Jake St. John. Rep. Geol. Surv. Canndn, 1857.

The Geology of the Lower St. Lnwrenee. Rep. Geol. Surv. Canadn, 1866.t59.

Roth, J.:-

Ueber das Vorkommen von Lnbrador. Sitz. Berlin. Aknd. X.XVIII., p. 697, 1883.

Selwyn, A. R. C.:-

Summary Reports of the Geol. Surv, Cunadi, for 1879-80 und 1889.

Selwyn, A. R. C., and Dawson, G. Ml.:-

Descriptive Sketeh of the Dominion of Cunnda. Published lyy Geol. Surv, Cunaln, 1882.

Steinlanuer, Il.:-

Note relative to the (yeology of the Const of Lalbrador. Tinus. Geol. Soc., London, Vol. II., 1814.

Van Hise, C. R.:-

Correlation Papers, Archenu nud Algonkinn. Bull, U. S. Geol. Surv., No. 86, p. $398,1892$.

Vogelsang, H.:-

Sur le Labradorite Coloré de la Côte du Labralos. Archives Néerlandaises, T. III., 186?.

Van Werveke, I.:-

Eigenthiimliche Zwillingsbildungen an Fekdspatlı und Diallag. Neues Juhrb. für Mlin., 1883, II., p. 97.

Wichmnnn, A.:-

Ueber Gesteine von Labrndor. Zeitschr. d. d. Geol. Ges., 1884, p. 486.

Wilkins, D. F. H.:--

Note on the Geology of the Labrador Const. Canndian Naturnlist (New Series), Vol. VIII., 1878.

Willianıs. G. H.:-

Deseribes Porphyritic Diubase or Diabase Porphyrite from Nachvak, and Horublendic Pyroxenite from near Skymner's Cove, Nachrak, Labindor. Ann. Rep., Geol. Surv. Caunda, Vol. V., Part I., 1890.91. Part F., Appendix I., Nos. 38 and 43.

DESCRIPTIONS OF THE ROCKS.

1. Ası Rock ?-Outlet of Dyke Lake, Ashuanipi Branch, Hamilton River. 
A durk coloured, fine-grnined rock, huving an anygdaloidal nppearance, due to einbeilded rounded little masses of cryatalline calcite with some harder minernl stnined red.

The rock exhibit imperfect partings and has porphyritically-cleveloped bisilicntes scuttered through it, now much decomposed.

Uncler the microscope it is seen to be composed of u confused unass of secondary iron ore, chlorite, epldote, calcite, etc., with some small, quite fiesh, porpliyritic hornblende crystals, which huve good cleavage nud somewhat sharp crystal outlines.

Owing to the extreme alteration of nenrly all its constituents, it is impossilhle to refer the rock with certninty to any particular type, but I am inclined to think that it may be $n$ bedded nsh rock.

\section{Uhalitic Gambro, on Gannro Diontw. - Grent Bend, Eust Main} River.

A dark green, fine-grnined, laminnted rock, somewhat mottled with white calcite, and having pyrite plentifully senttered through it.

In the thin section it is seen to be much altererl, squeezed, and shenred, producing vory une ven extinction in its constituent minernls.

It possesses n crystalline granitio structure, and consists chiefly of plagioclase, horublende, magnetite, quartz, pyrite, apntite, epidnte ano chlorite.

The plagioclase is in allotriomorphic individuals which are almost entirely snussuritized, but still retuin traces of the original twinning strintion, and are frequently penetrnted by slender little crystals of apatite.

The hornblende, which hns every appenrince of bein's secondary in origin, is the "compact" variety so cliarncteristic of those rocks which hnve been subjected to metamorphism. It is green in colour and strongly pleochroic, with $n=$ greenish-yellow, $v=$ yellowish-green, and $\mathfrak{f}=$ bluish-green. Teall $\dagger$ lins pointed out that this development of hornblencle at the expense of augite or dinllage in basic igneous rocks in regions not affected by contact metnmorphism, is one of the most definitely established fncts in petrograplical science.

The hornblende of this rock occurs in irregulnr aggregntes of grnins linving no uniform orientation. Some quartz, npparently secondary, Inuch cracked, and with very uneven extinction, is present, and pyrite is exceedingly abundant.

* That is, homogeneous, neither fibrous, nor actinolitic.

+ British Petrography, 1888, 1. 161.

$22 \frac{1}{2}$ 
This combination of saussurite and secondary "compact" hornblende, as the result of the alteration of gabbros, is very charncteristic and has frequently been described.

3. Diabase, 'higmly altered.-Head of Dyke Lake, Ashuanipi Branch, Hamilton River.

A dark gray, fine-ained, rusty-weathering rock, holding numerous si. all white oval patclies, consisting chiefly of ca'cite, which give it a decidedly porphyritic appearance. Smaller, dark coloured porphyritiforms also occur, which were probably augites.

On weathered surfaces the rock has a cavernous nppearance, due to whe removal of the calcite in the oval areas referred to above.

As seen in the thin section, the rock is much altered and filled throughout with crystalline calcite.

Small, interlacing, lath-shaped crystuls of plagioclase make up tho bulk of the section, giving to it a decided ophitic structure, and it is thickly sprinkled with little granules of secondary iron ore and senles of chlorite. Comparatively large patches of calcite and chlorite represent what were probably originally phenocrysts of plagioclase and augite.

The rock is apparently a much altered and highly calcareous diabase.

4. Hornblende Schist, probarly resultixg from tile silfarivg of Sone basic eruptive.-Jacopie Lake, Hamilton River.

A rather light green, fine-grained, glossy, chloritic schist, with intercalnted red felspathic layers, and very wavy and crinkled lamination.

Yicroscopic examination shows that it has been subjected to intense shearing action, the hornblende being all pulled-out, and the larger plagioclase fragments occurring in elongated strenuns of finely-granulated material of the sume kind.

The principal minerals present are lornblende, felspar (both striated and non-striated), chlorite, epidote, a little quartz, and a very little iron ore and titanite.

Streaks of finely-granulated felspar, evidently derived from the breaking-up of larger individuals, fragments of which still occur distributed through the granulated material, alternate with wavy streaks of hornblende pulled-out in the same manner from larger individuals. These hornblende layers wind around the larger fragments of felspar in such a manner as to give a regular "flow-structure" to the section.

In one instance a large felspar individual lies almost at right angles to the general direction of lamination of the rock, and the hornblende layers bend around it in a most marked manner. 
Both twinned and untwinned felspar grains occur, but the former are more plentiful. Inclusions are very common.

The hornblende is compact, except where it has been excessively diawn-out by the sheuring action to which the rock has been subjected. It is now generally of pale yellowish or bluish-green tints, cwing to chloritization, possesses well-marked cleavages, and rather feeble pleochroism.

The rock may be regarded as a greatly sheared and crushed basic eruptive, perhaps a diorite.

\section{Crushed Quartz PorPirri.-Mouth of Akuatago Rirer, East} Main River.

In the hand specinen this is a medium-g:ained rock of a somewhat dark gray colour, mottled with whitish phenocrysts of quartz and felspar, and with a lamination due to shearing. Many of the quartz phenocrysts exhibit a bluish opalescence. Pyrite and calcite are plentiful, the rock effervescing freely with dilute hydrochloric acid. The thin section shows a micro-granitic groundmass composed of quartz and felspar, in which lie numerous phenocrysts of quartz and felspar, the former frequently having a rule dihexahedral form, and the latter being mainly non-striated and probably orthoclase.

Biotite in irregular scales and aggregates, accompanied by some muscovite, is abundant. A little hornblende is present, and pyrite, epidote, chlorite, titanite, zircon, and apatite also occur.

The rock has been greatly crushed and sheared; the phenocrysts of both quartz and. felspar possess very uneven extinction, are inuch cracked, and peripherally granulated.

The felspar is decomposed and filled with carbonates, epidote, muscovite, and other alteration preducts. A few slender needle-like crystals of an intensely pleochroic (irrligo-blue to light yellow or alnost colourless) mineral resembling tourmaline were observed. The biotite is largely altered to chlorite. Some of the epidote possesses the low double refraction of zoisite. The rock may be regarded as a much crushed and sheared quartz porphyry. Only small portions of it have resisted the crushing action.

\section{Hrpersthexe Srenite Gxeiss.-First Gorge of the Koksoak} River.

A rather coarse-grained, greenish-gray, gneissic rock, with granitic structure, and consisting chiefly of a non-striated felspar, a little quartz, an orthorhombic pyroxene strongly pleochroic in light-green and pink tints, a deep reddish-brown pleochroic biotite, apatite, and iron ore. 
A very few grains of plagioclase were also observed. Micropegmatitic structure is beautif,lly shown in portions of the section. The rock is tolerably fresh, but the orthorbombic pyroxene (hypersthène) shows the characteristic alteration, the grains being traversed by a network of cracks filled with serpentinous material.

A determination made in the Laboratory of the Survey, gave $62.6 \mathrm{~S}$ as the percentage of silica present in the rock. This would place it with the syenites rnther than with the granites, and it might perhaps be termed a hyper ul:ene syenite containing a little quart\%. It bears a close resemblance to some of the rocks from Château Richer, Quebec, describsá by me as pyroxene grunite gneisses but which have not yet been analysed.

7. Gabbro, approaching diabase in structure.-End of Survey, Ashuanipi Branch, Hamilton River.

A very dark coloured, medium-grained, massive-looking rock, having for its principal mineral constituents plagioclase felspar, stained brown by decomposition products; monoclinic and rithorhombic pyroxenes, the former being the inore abunrlant; some deep reddish-brown strongly pleocirroic biotite; ilmenite accompanied in some cases by leucoxene; a small quantity of apatite.

The structure, whilst in the main that of a gabbro, in some portions is ophitic, approaching in that respect to a diabase.

8. Gabiro Gskiss ?.-Ossokmannau Lake, Attikonak Branch, Hamilton River.

A medium-grained, dark green and brown, rusty, gneissic rock, which, under the microscope, is seen to be greatly granulated, affording an excellent example of Törnebolim's "mortar-structure." Both strialed ind non-st. iated felspars are present, the latter in considerable quantity, so that a separation would be necessary to determine its true character. But I am inclined to believe that much of this nonstriated material is plagioclase, as pressure-twinning has been developed in portions of some of the grains. Quartz is present, but not abundant, and both monoclinic and orthorhombic pyroxenes occur. The monoclinic form is pale-green in colour and feebly pleochroic, whilst the orthorhombic (hypersthene) is strongly pleochroic in red and green tints. Hornblende and biotite occur in small irregular individuals, and ilmenite with lencoxene is very abundant. The rock has a granitoid si ucture, and exhibits abundant evidence of intense dynamic action in the cracking and granulation of its constituent minerals,

"Ann. Rep, Geol. Surv. Can., vol. V., 1890-91, part L., apuendix, pl, \$1, \&2. 
and their very uneven extinctions. It is stuined a yellowish-brown colour throughout, due to hydrous oxides of iron.

9. Greywacke.-Outlet of Cambrian Lake, Koksuak River.

An exceedingly tine and even-grained, massive, dark green, rustyweat bering rock, the clastic origin of which is at once revealed by the microscope. It consists of angular and sub-ungular fragments of quartz and felspar with granules of iron ore and epiclote, in a ma'rix, not at all abundant, oî sericitic and chloritic material. Both striated and non-striated felspar are present, and the rock is a typical greywacke.

10. Dionite ?.-Ten miles above Broken Paddle River, East Main Iiver.

This is a medium-grained massive rock, of a very dark g:een colour, mottied with yellowish-brown, and showing an indistinct foliation. The microscope shows it to consist of a clear mosaic of interlocking grains, evidently re-crystallized, and containing both felspar and quartz, although it is now impossible to distinguish between the two minerals without obtaining axial figures.

Through this mosaic are scattered irregular patches of a green, strongly pleochroic, compact hornblende, which has a secondary appearance, and is frequently arranged in rudely radiating groups of individuals. It is intimately associated with patches of granular, and upparently secondary, iron ore. The section suggests a basic eluptive rock, which has been changed to its prese it condicions by contact or dynamic metamorphism.

I1. Dionite, extrimely altrinid.-Muskrat Falls, Ham ion River.

A medium-grained, somewhat folinted, dark yellowish-grten, rusty weathering rock, the hand specimen of which is studded with small cubes of pyrite. Uncier the microscupe it is seen' to be in $n$ highly altered end crushed condition, consisting now chiefly of much decomposed and granulated plagioclase felspar, small masses of fibrous chloritized hornblende evidently secondary in origin, and patches of a peculiar deep brown grunular titanite, which, from the fact that they bold occasional cores of ilmenite, have probably been derived from the alterition of that minerul.

The whole section is filled with the products of decompo-ition, such as epidote, chlorite, and sericite, and is plentifully sprinkled with pyrite. The rock is evidently $n$ much altered diorite, perhaps derived from a gabbro. 
12. Uralitic Gamuro.-Iookout Mountain, near Grand Falls, Hamilton River.

A medium-grained, mottled green and yellowisl-white, massivelooking rock.

The thin section shows it to be greatly altered, with a gabbro-like structure, and consisting prineipally of plagioclase felspar (some nonstriated grains al:o occur); hornblende of a pale green colour and uralitic appearance, having the borders of the grains of a darker colour than the eentres; a deep brown strongly pleochroic biotite intimately associated with the horublende, and ilmenite with leucoxene.

The felspar is full of prismatic crystals of epidote and scales of sericite. Chlorite is very abundant in the section. The rock is evidently an aitered gabbro.

13. Prroxenite (Hyperstuenite).-Five miles above the Minipi Braneh, Hamilton River.

The hand specimen shows a coarse-grained mixture of broad taljular crystals of hypersthene and plates of biotite, the rock being of a brownish-green colour, and these two minerals apparently its sole constituents.

About the only minerals observed in the thin section were a strongly pleochroic ortho'hombic pyroxene (hypersthene) and a deep brown biotite. A very few minute areas of a clear, colourless mineral, apparently quar'tz, lie between some of the pyroxene grains.

The orthorhombic pyroxene is quite fresh, and, as stated, strongly pleochroic, with $\mathrm{b}=$ red, $\mathfrak{v}=$ yellowish-green, $\mathfrak{r}=$ green.

Examined in convergent light it gave the optical eharacters of hypersthene. It is remarkably free from the clark scales and rnds usually present in that mineral, a fact ulready noted by Dr. Adlams in the ease of the Norian rocks of Canada.* The rock is evidently a member of the pyroxenite group and may be termed a hypersthenite.

14. Diallase?, extrenely alteren,-First Portage from Obatagoman Lake to Clibougamoo Lake.

A pale green, fine-grained, rusty-weathering, massive-looking rock, with indistinet traces of foliation. This is an extremely altered basic eruptive, probably a diabase, as traces of ophitic structure can still be detected in the section, which is traversed by little eracks filled with quartz, and exhibits such a stuge of decomposition $n$ s to render a minute description of no special interest. The bisilicate, augite, origi-

* Teber das Norian chler Ober-Iaurentian von Canada. F. I). Adanis. Stuttgart, 1893. 
nally present, has been changed to a fibrous hornblende, and this again is largely altered to chlorite. The plagioclase felspar is almost com. pletely saussuritized.

15. Porpirritic Diabase, - On the portage route between Obatagoman and Chibougamoo lakes.

A durk green, fine-grained, massive, porphyritic rock, with distinct ophitic structure in the groundmass and having numerous large pheno. crysts of plagioclase scattered through it.

The rock is much altered, but the ordinary structure of a diabase is seen in the thin section. The numerous porphyritically-developed plagioclases are mucl saussuritized. The section is thickly sprinkled with small granules of iron ore and presents no unusual features.

16. Amphibolite (sileared basic enuptive).-Ten miles nbove Broken Paddle River, East Main River.

A medium-grained, pale greenish, well-foliated schistose rock, with slickensided surfaces evidently due to shearing. The thin section shows that the rock has been subjected to intense dynamic action, consisting now of a very finely granulated mosaic of quartz and felspar in which a few larger fragments of these minerals are embedded, together with bunches of a fibrous hornblende, now largely altered to chlorite, and patches of a peculiar deep brown granular titanite evidently resulting from the decomposition of ilnenite and still holding an occasıonal small core of that mineral.

The rock has evidently resulted from the shearing and crushing of some basic eruptive, perhaps a gabbro.

17. Ampinmolite (silfared basic eruptive).-Ten uniles above Broken Paddle River, East Main River.

A dark green, medium-grained, distinctly banded rock, having a much more massive appearance than No. 16, to which, as regards origin, it is closely allied; but re-crystallization has proceerled farther in this case and it is consequently in a much fresher condition. Its foliated character is well seen in the section. The quartz and felspar form a clear interlocking mosaic, and the hornblende is of the " compact" variety so characteristic of rocks of this class and is intergrown with the quartz and felspar. A brown pleochroic biotite, apparently secondary in origin, is abundant in small scales distributed through the quartz-felspar mosaic. Small granules of iron ore are also plentiful. 
The rock as seen in the section is apparently the final stage of alterntion of some basic eruptive and greatly resembles that described by Tcall in the case of the Scourie Dyke in Scotland.*

18. Uralitic Diabase.-Two miles below Ross Gorge, East Main River.

In the hand specimen this is a dark greenish-gray, fine-grained, , massive rock, with distinct ophitic structure and containing much pyrite.

The section reveals the fact that both plagioclase and augite are extremely ultered, but the structure of the rock is undoubtedly that of a diabase. Granules of iron ore and epidote are plentifully scattered through it in addition to the pyrite.

The augite has altered to a tibrous hornblende which, in its turn, has become largely shloritized.

19. Horndende Graxite Gxeiss. - Three miles above Grand Falls, Hamilton River.

A rather coarse-grained, well-foliated, greenish and yellowish "augen"-gneiss.

A marked cataclastic and foliated structure is exlibited in the thin section. La:ger fragments of quartz and felspar are embedded in a finer-grained mosaic of the same materials, through which run strings of hornblende and biotite with large crystals of a clove-brown, strongly pleochroic titanite.

Both orthoclase and plagioclase occur, the former predominating, and occasionally showing the structure of microcline due to pressure.

The rock has apparently been partially re-crystalliz̧ed and is filled with needles and irregular grains of epidote. The larger fragments of quartz and felspar are remarkably full of inclusions of this und other minerals. The titanite crystals are remarkable for their size and deep brown colour.

I regard the rock as being a hornblende granite squeezed into a gneiss.

20. Dis'ise, extrenely altered.-Lake Petitsikapau, Ashuanipi Branch, Hamilton River.

A fine-grained, dark green, mussive rock, full of pyrite. The thin section shows two portions of the rock, an outer and more altered portion, a.d un inmer one, which, whilst still much altered, is not quite so much so as the outer or surface portion.

* Teall. On the Metamorphosis of Dolerite into Hornblende Schist. (). J. (†. S. vol. XLI, 1885, p. 133 ; also Britisl Petrograpliy. p1. 154, 198-200, and plate XXI. 
The inass is evidently diabasic in character, the ophitic stiucture being still visible. The pyroxene now exists as small cores in masses of brown serpentinotis decomposition products lying between the lathshaped sections of plagioclase. The lighter anch more highly altered portion of the scction contains more light green clulorite than the darker.

Irregular patches of lencoxene with occasional cores of ilmenite, and pyrite, ure plentiful. An orthorhombic pyroxene is nlso apparently present in small quantity. Epidote is abundant, often in radiating bundles of needle-like crystals.

21. Crushed Granite (or Syenity, ?).-Foot of Great Bend, East Main River.

A mottled, greenislı-gray and white, medium-grained, granitic-looking rock, which has been greatly crushed and now consists of a mosaic of felspar and quartz lying between larger grains of these minerals ("mortar-structure"), witl scales of biotite plentifully distributed throughout the mass. Epidote is exceedingly abundant, and occasionally encloses sharply defined pleochroic allanite crystals. Much of it has evidently resulted from the saussuritization of the felspar and is accompanied by sericite.

Both orthoclase and plagioclase are present, but the former greatly predominates. Some titanites and apatites also occur.

In the particular section examined, quartz is coniparatively scarce, and suggests that a further study and analysis of the rock might lead to its being placed with the syenites rather than with the granites.

22. Diarase, sucu altered.-Outlet of Dyke Lake, Ashuanipi Branch, Hamilton River.

An exceedingly tine-grained, dark green, rusty-wenthering, compact, massive rock, with occasional felspar crystals embedded in it. It is now extremely clecomposed and filled with calcite, epidote, chlorite, hydrous oxides of iron, and other alteration products, but traces of its original ophitic structure may still be seen. Magnetite in small granules and crystals is abundant. The rock is undoubtedly a highly altered diabase.

23. Dronite ?-Five miles below Stillwater Branch, Koksoak River.

A medium-grained, greenish-gray, rusty weathering rock, which the thin section shows to be made up of a bleached chloritic hornblende associated with much sanssuritized plagioclase felspar. 
Leucoxene, resulting from the alteration of ilmenite, is abundant, and pyrite is also sprinkled through the mass. The horrblende couveys the impression of being primary in its origin and occasionally shows a twinned structure. The rock is probably a decomposed diorite.

24. Axortiosite.-First lake on portage route from Romaine River, to St. John River.

A pale grayish, almost white, medium-grained, crystalli:e granular rock, looking very much like a crystalline limestone.

Only a few streaks and spots of coloured bisilicates occur in the specimen, which is mainly composed of plagioclase felspar.

This is a typical representative of that division of the gabbro fumily . in which the coloured constituents constitute only a very insignifican portion of the mass of the rock. The section is almost entirely composed of clear, colourless, well-striated labradorite with an extinction angle on $\infty \mathrm{P} \notin$ of about $25^{\circ}$. It is in general quite fresh, but traces of alteration to sericite, calcite, epidote, zoisite, etc., were here and there observed. A very few irregular grains of a fresh green horublende, with the characteristic clcavages and pleochroism of that mineral, are present, usually associated with an opaque iron ore, which also occurs in smaller granules dotted through the felspar.

Mica and hypersthene are also present in other portions of the rock.

25. Mica Diorite Gneiss (crusil kd and altered kluptive?)-On's mile above Broken Paddle River, Eust Main River.

In the hand specimen this is a dark greenish-gray, distinctly foliated and rusty-weathering rock, having numerous fragments and crystals of quartz, felspar, and hornblende scattered through the finer-grained groundmass, also numerous cubes of pyrite.

It lias evidently been greatly crusherl and squeezed and now consists chiefly of a fine-grained quartz-felspar mosaic containing larger fragments of these minerals, much biotite, and some hornblende larely altered to chlorite. Pyrite, titanite, epidote, ilmenite with leucoxene, and a large quantity of calcite are also present. Owing to the extremely granulated condition of the material it is difficult to make out the nature of the felspar, lut plagioelnse appears to predominate (it certainly does in the larger fragments) and the rock is probably the result of the erushing of a diorite or gabbro.

26. Dionite (Altered gabBro?)-Near mouth of Akuatago River, East Jlain River.

A clark greenish-gray, medium-grained, indistinctly folinted rock. 
The section bears evidence that it has been grently erushed and granulated. Plagioclase felspar, hornblende, some quartz, biotite and iron ore are the principal minerals present. Pyrite, apatite, chlorite, and epidote also occur.

Much of the hornblende has a frayed-out, actinolitic appearance, and ocensionally surrounds more compact cores of $\Omega$ deeper green colour, largely altered to chlorite, which resemble augites.

The biotite is largely secondary and is intimately intergrown with the hornbiende.

The rock may he an extremely altered gabbro.

27. Uralitic Gaibro, witu an approacit to diabasic structure. -Eight miles above Broken Paddle River, East Main River.

A dark green $m$ 'ttlerl with white, compact, rusty-weathering rock. It is much nltered and now consists chiefly of plagioclase felspar und a pale green uralitic hornblende, the individuals of which have borclers of $\Omega$ deeper colour than the centres.

The section is filled with granules of epidote, chlorite, und other decomp sition products. Some titunite is ulso present. An appronch to dinbasic structure may be seen in portions of the rock, which, in the main, may be regarded as a crushed and altered gabbro.

28. Extremely crusied ponpiyritic rock?-Three miles above Broken Paddle River, East Main River.

A dark green, somewhat porphyritic, indistinctly foliated rock. 'The section oxhilits such an extreme stage of granulation as to render a determination of the true character of the rock a matter of great difficulty.

Fragments of plagioclase, orthoclase, qua tz, and granules ot. Iron. ore with numerous scales of an apparently se sondary biotite, are scattered through a very fine-grained quartz-felspar mosaic. Pyrite is rather abundant.

29. Dronte.-Prosper Gorge, East Diain River.

A mediun-grained, dark green, rusty-weathering, compact, massive rock. Plagioclase felspar and a pale green uralitic hornblende are its chief constituents, together with some biotite and iron ore.

The plagioclase is quite fresh, and portions of the section lave a decided diabasic structure.

The whole of the hornblende may have resulted from the alteration. of the augite of a dinbase, as, although no cores of the latter minera. were detected, the hornblende has a secondary appearance. 
30. Altened Diallase.-One mile below Akuatngo River, Enst Main River.

A dark gr'een, chloritic-looking rock, which in the thin section exhibits a conrse ophitic structure, the spaces between the plagioclase crystnls being filled with a muss of scales of rather pale brown biotite, evidently of secondary origin. The plagioclase is very turbid. No iron ore was seen in the section.

31. Altrendi Dianase. -Thirce miles and a half above Broken Puddle River, Enst Mluin River.

A meliun--rgmined, dark green, rusty-wenthering, compuct rock, in which the plagioclase felspar is almost completely saussuritized, retrining only truces of its original strintion.

The augite is largely altered to pale green hornblende, chlorite and a serpentinous sulsstance. lipilote, and ilmenite necompanied by leucoxene are abundant. A little qunitz wis scf..

The section shows the typical ophitic structure of $a$ dinbnse.

[The three following deseriptions of rocks from Iabralor have been conclensed from a putuer by Mr. A. F. Barlow" of this Survey : ]

32. Ganbro, witu an approacil to diallasic structure.-Ten miles north of Lake Kawnchagnmi, on the portage route between the Rupert and East Main Rivers.

In the hand specimen this is a dark greenish gabbro-like rock, with yellowish-green plagioclase phenocrysts. It consists chiefly of plagioclase, nugite and ilmenite.

The larger phenocryst3 of plagiociase show marked alteration, and are precisely similur to those described by Thompson as "Huronite." Their specific gravity is $2 \cdot 725$.

The nugite is largely altered to hornblende, but cores of the former mineral still remain. Ilmenite, occnsionally altered to leucoxene, is rather abundunt. Epidote is present as a decomposition product, and apatite is very plentiful. Considerable areas of granophyre were observed in the section, portions of which also show $a$ coarse ophitic structure.

33. Oluvine Diabase.-Fault Hil, Dyke Lake, Ashuranipi Branch, Hamilton River.

In the hand specimen this is a medium-grained, dark green almost black rock, with occasional small imperfect phenocrysts of snussuritized

*On some Dykes containing Huronite, by A. E. B.urlow. M. A., Ottawa Naturalist, vol. IX., No. 2, 1895. 
plagioclase. Under the microscope it is seen to be composed chiefly of plagioclase, considerably altered to saussurite, especially in the case of larger individuals ; fresh brownish-red, pleochroic nugite, mostly allotriomorphic in form, but oecnsionally with shurp erystal outlines; serpentine, which has evidently resulted from the alteration of olivine; and ilmenite in large irregular fragments and small granules, in both cases showing alteration to leucoxene.

34. Dialuse. - Neal ontiance to Dyke Lake, Asluunipi Branch, Hunilton River.

A dark greenish-gray, rather conrse-grained rock, in which are em. bedded numerous phenocrysts of nltered, greenish felspar (Huronite), some of which in the main mass of the rock are three-fourths of an inch in dianeter.

They are extremely abundant, and, together with the plagioclases of the groundunss, are largely altered to sericite and epiclote. Their specific gruvity is $2 \cdot 773$.

The augite, when fresli, which is rarely the case, is reddish in colour and distinetly pleochroic. Ilmenite, nltered to loucoxene, is abundnut, ns are also chlorite, apatite and pyrite. 


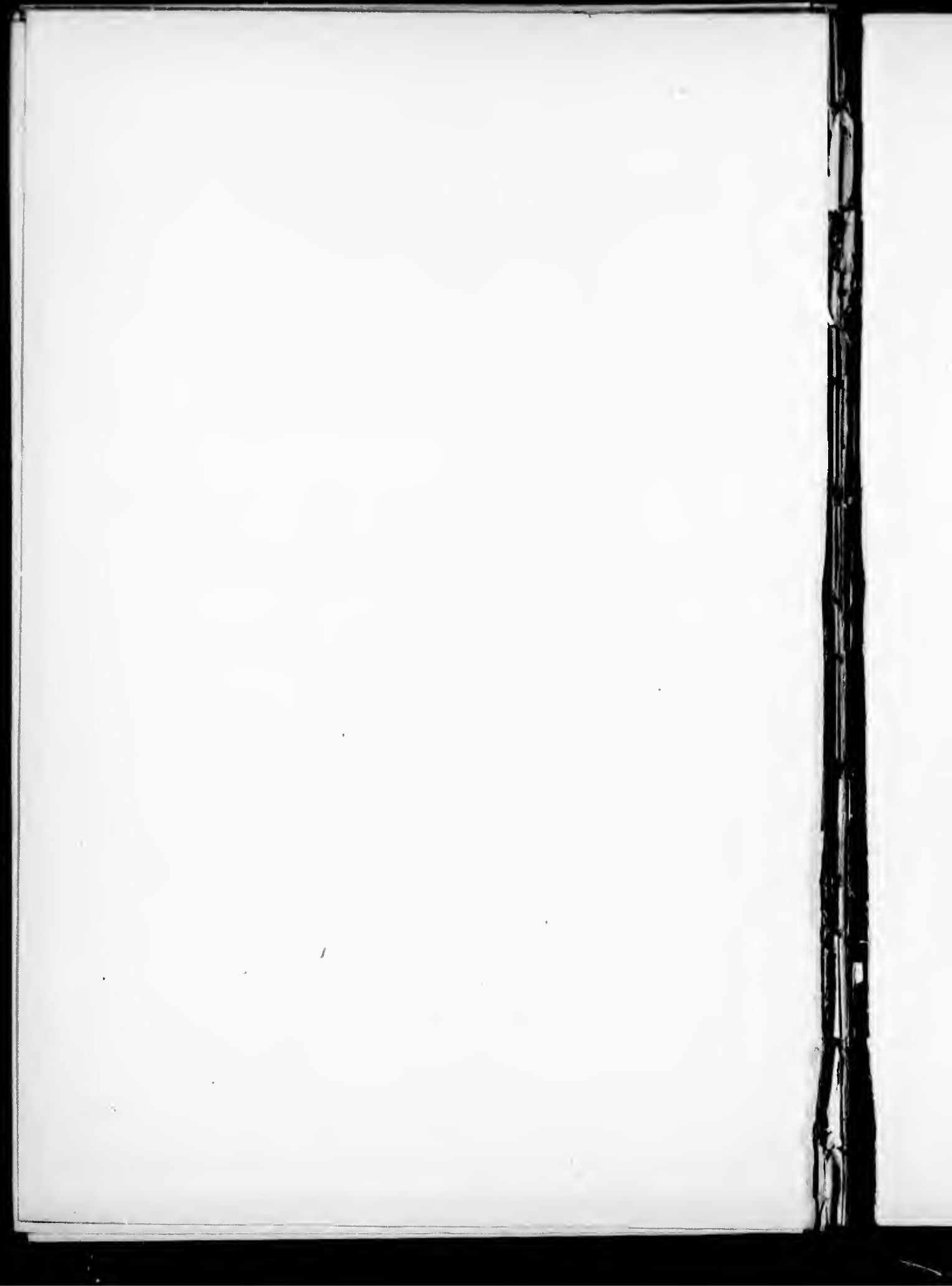




\section{APPENDIX VI.}

Last of the Phasts known to occull on the Co.sst ant is tule Ixterion of tile Lamindon Pexissula. Compiled iM Jases II. Macou.

Tho following list, which has been carefully compiled from lists already published and from MS. notes and specimens in the herba: ium of the (ieological Survey, is divided hito four columns, so that the distribution of each species, so far ns known, mny be seen nt a glance.

The first column contains those species known to occur on the const of Labrador, the second those growing in the basin of the upper Hamilton River, the third those growing in the basins of the Rupert and kist Mnin rivers and the fourth those growing along the shores of James Bny. The aren included in the second and third columns comprises the whole central part of the peninsula, and many of the plants noted in the third column and not in the second doubtless grow in the basin of the Hamilton River; but, while the third column represents the collections made in three seasons, under favourable conditions and over a wide aren, one season only was spent on the Hamilton River.

The first column has been copied trom Dr. Packard's "The Lalorndor Const," with the addition of a few species overlooked when his $t_{\text {i }}$ t was compiled, or which have since been collected. The species included in the other three columns have all been collected by Mr. Low or his assistants, Mr. J. M. Macoun having made the collections in 1885 and 1887 , and Mr. A. H. D. Ross, in 1892, the very complete collection of the plants growing along the East Main River. Lists of the plants found at Lake Mistassini, on the Rupert River and along the shores of Jannes Bny have been printed as addenda to Mr. Low's reports of 1885 and 1887 , and to these the results of his explorations in 1888, 1892, 1893 and 1894 are now added.

Recent revisions of genern have in some cases changed the names that nppenr in this list, but to obviate the printing of synonyms the names under which species and varieties have been alrendy recorded from the Labrador Peninsula have been retained, except where a correction was necessary or there was the possibility of confusing two plants : in such cases both names are given. 


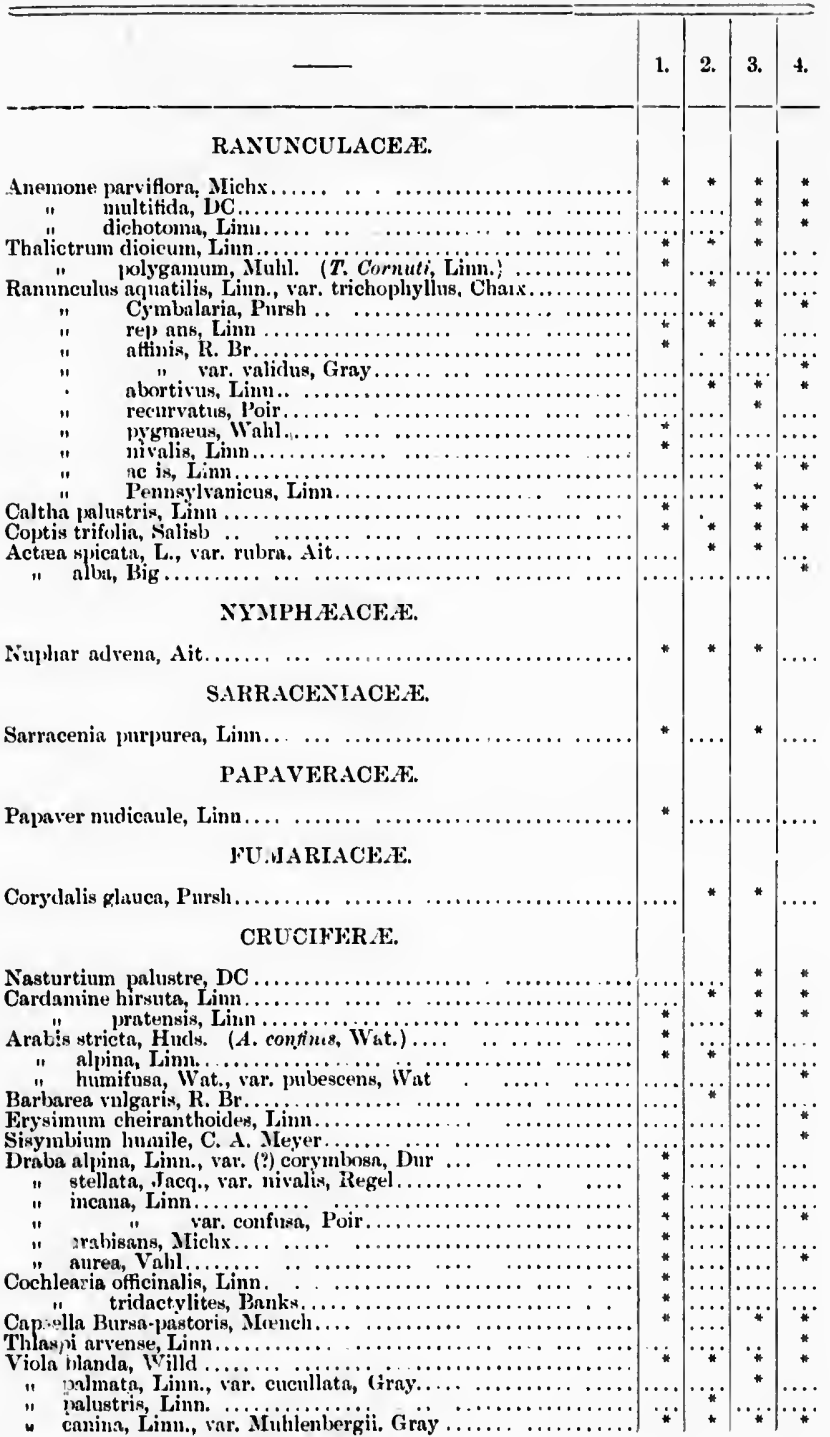




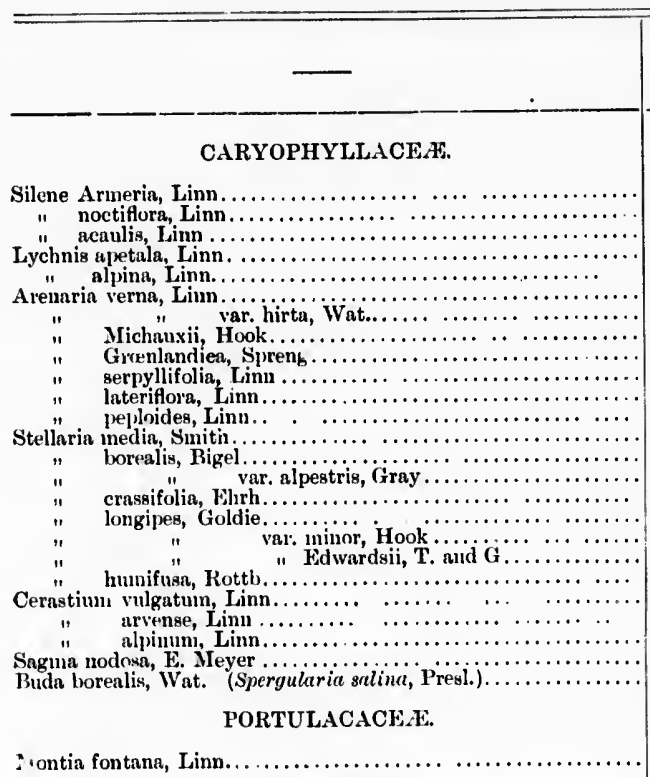

S ontia fontana, Linn...

\section{LINACEAE.}

Linum perenne, Liun

\section{GET ANIACE王}

Granium Carolinianum, Linn.

\section{RHAMNACEA}

Rhammus alnifolius, L'Her.

\section{SAPINDACE $\mathrm{F}$}

Acer spicatum, Lain.

\section{LEGUMINOSEA}

Trifolium repens, Linu...

Astragulus alpinus, Linn.

${ }^{\prime}$

Oxytropis podocarpa, Gray.

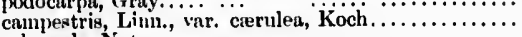

Hedysarum boreale

"Americana, Minhi

Lathyrus maritimus, Bigel

$$
\begin{aligned}
& \text { " paluster, Linı. } \\
& \text { " }
\end{aligned}
$$

\section{ROSACF:E.}

Prunus Pennsylvanica, Linn. Spirea salicifolia, Linn

$$
23 \frac{1}{2}
$$




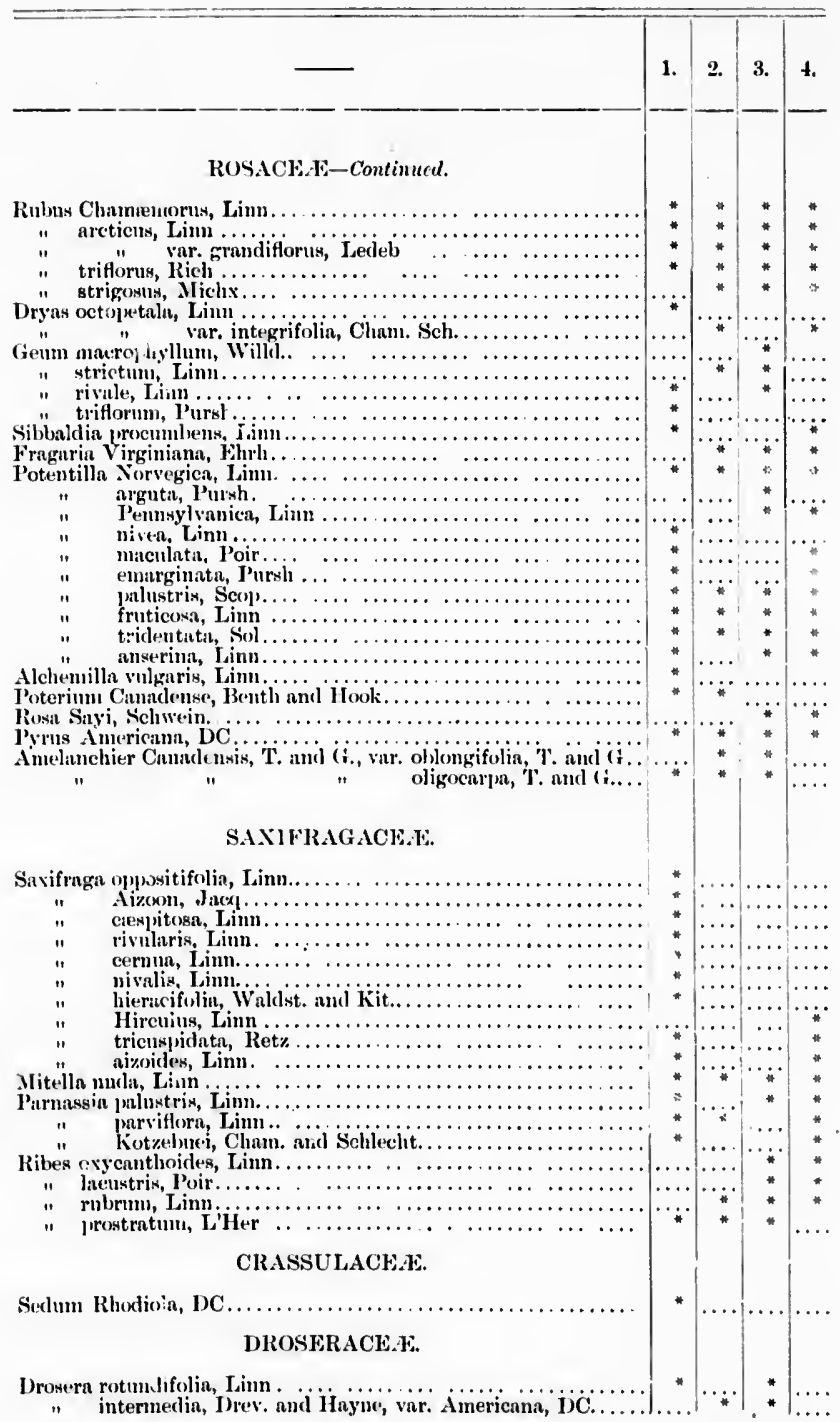




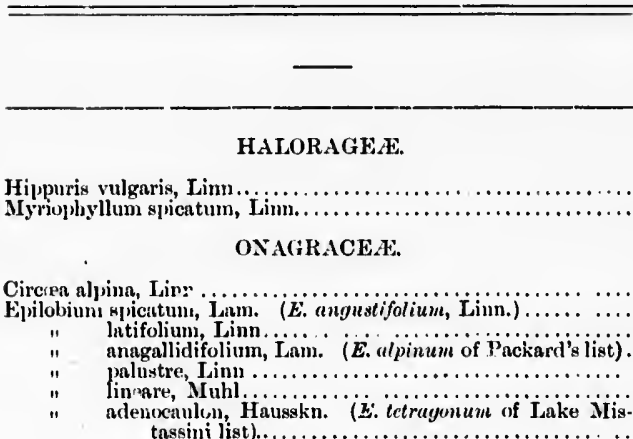

\section{UMBHLLIFERE.}

Sauicula Marilandica, Liun

Nium cientıefolium, (inuelin

Cicuta unaculata, Limu.

$$
\text { I Inlbifera, Limm }
$$

Ligustieun Sioticum, Linu

Arehingelien at opurpurn

Heracleum (imatimi, J)C.

ARALiACE.E.

Aralia hispida, Miclıx. nudicmulis, Lis...

\section{COMLCEA.}

Coruus Canadensis, Linn. suecica, Ijunn

sericea, Linn

stolmifera, Michx

\section{CAPRIFOLIACEA.}

Sambucus racemosa, Limu., var. pulsens, Wat

Viburnum pnuciflorum, Pvlaie.

Linnea borentis, Gronov.

Lomicera involcrita, Banks. cresulen, Iinn

Diervilla trificla, Juench

\section{RULIACEA.}

I ialium asprellum, Michx tritirlum, Linn....

triflorum, Nichx.

lworeale, Linu......

\section{VALERIANACFE}

Valeriana sylvatica, Riclı

\section{COMPOSIT.E.}

Fupatorimm jurpmrem, Limm,........ Sol lago hicolor, Limn., var, concolor, Torr. and Gray. 


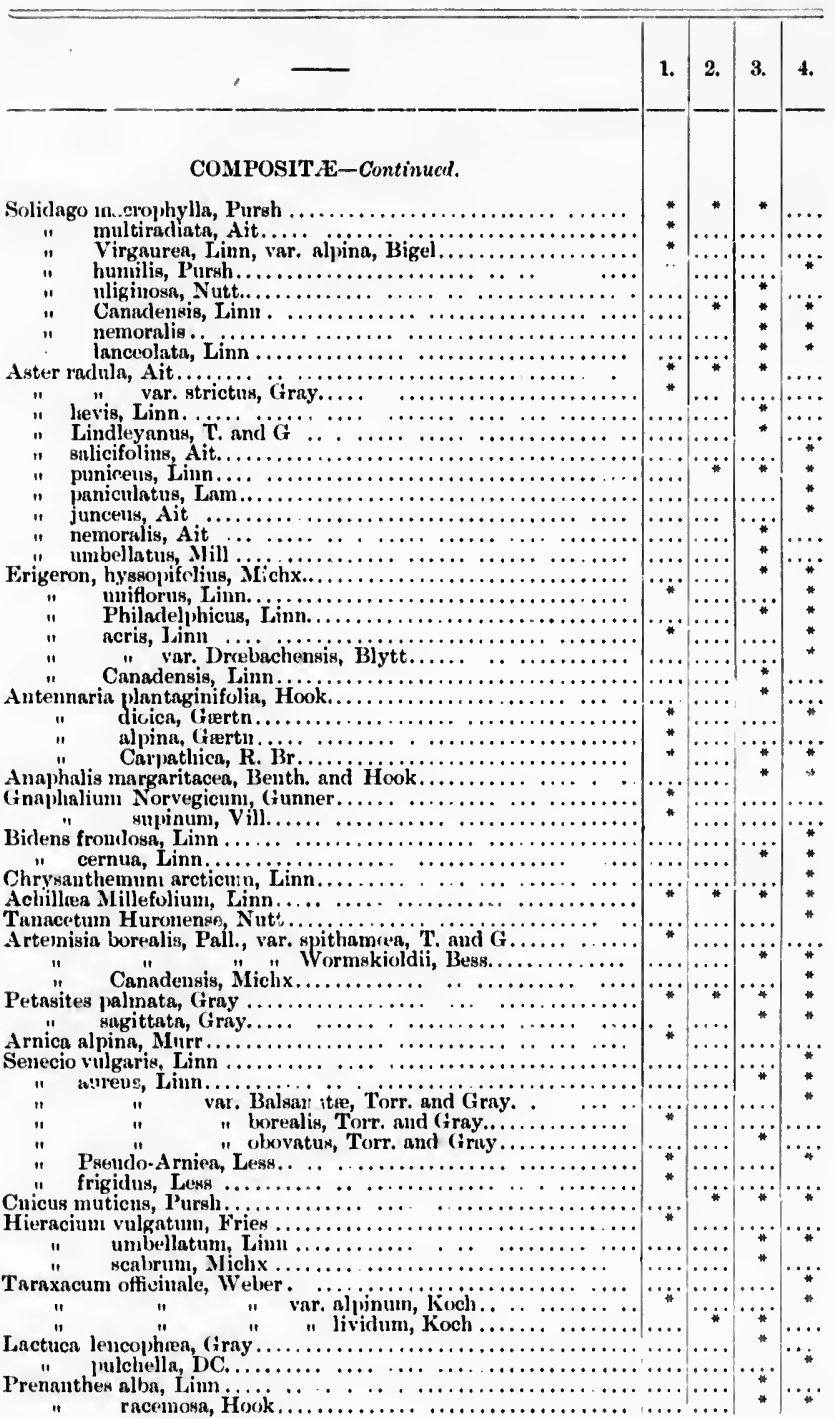




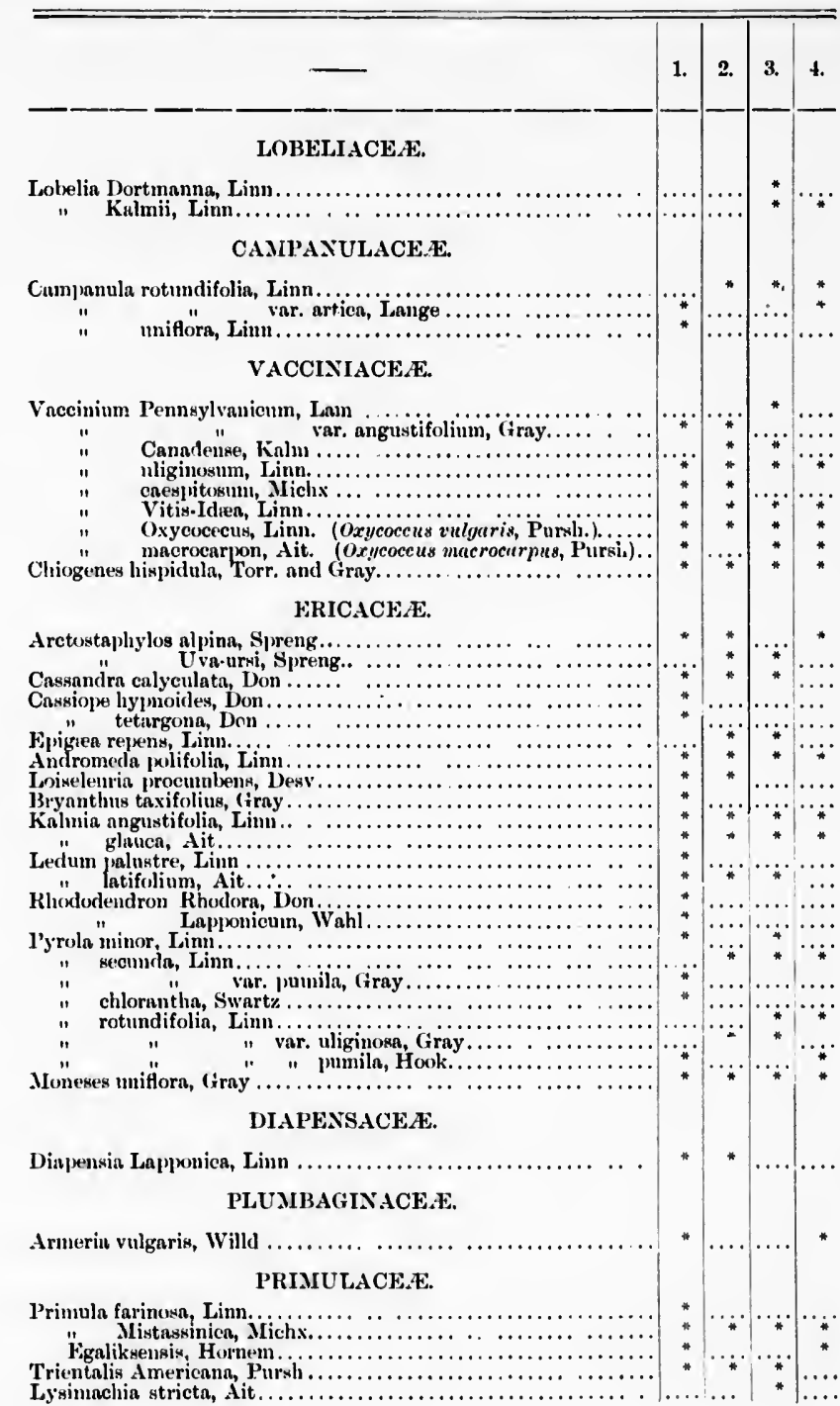




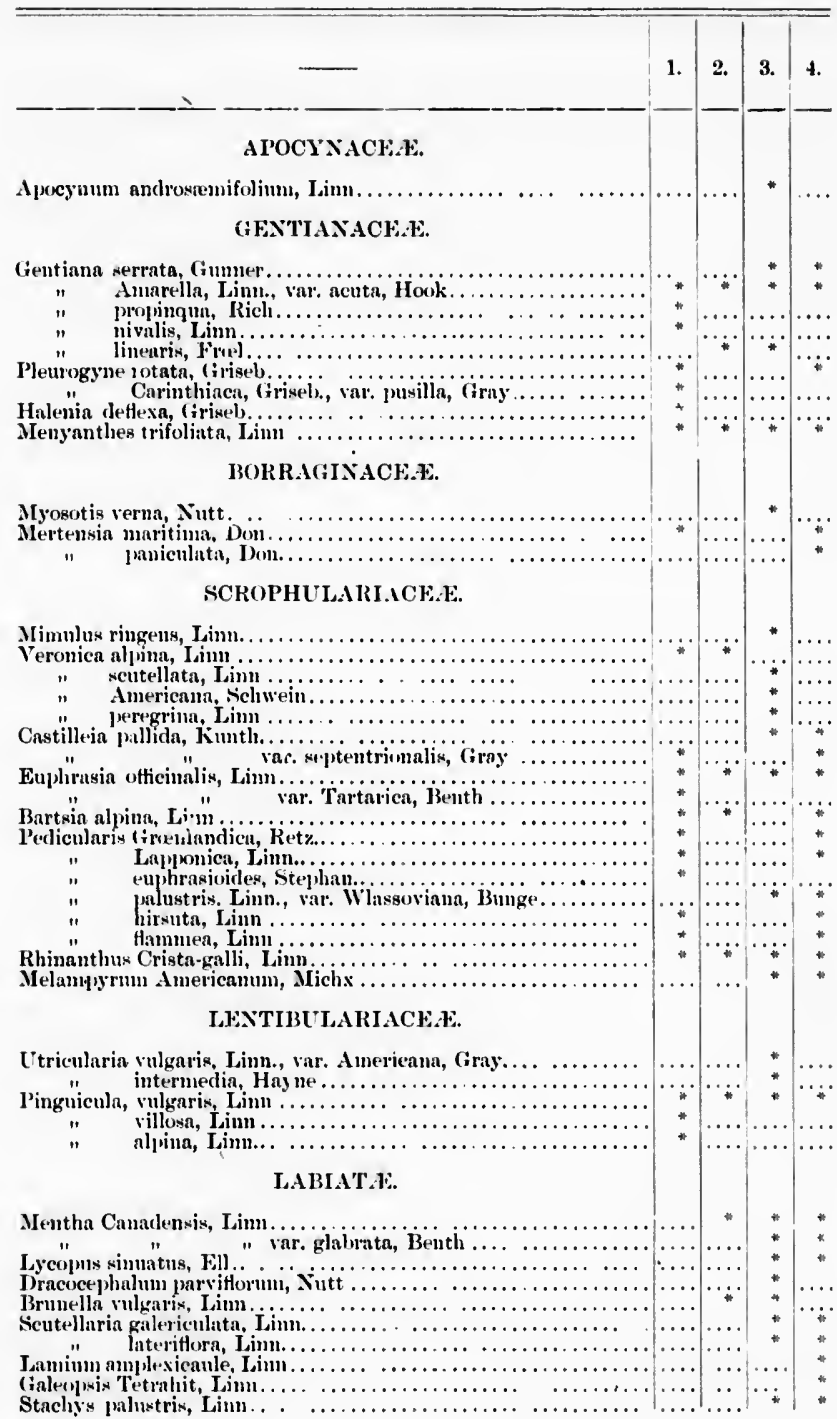



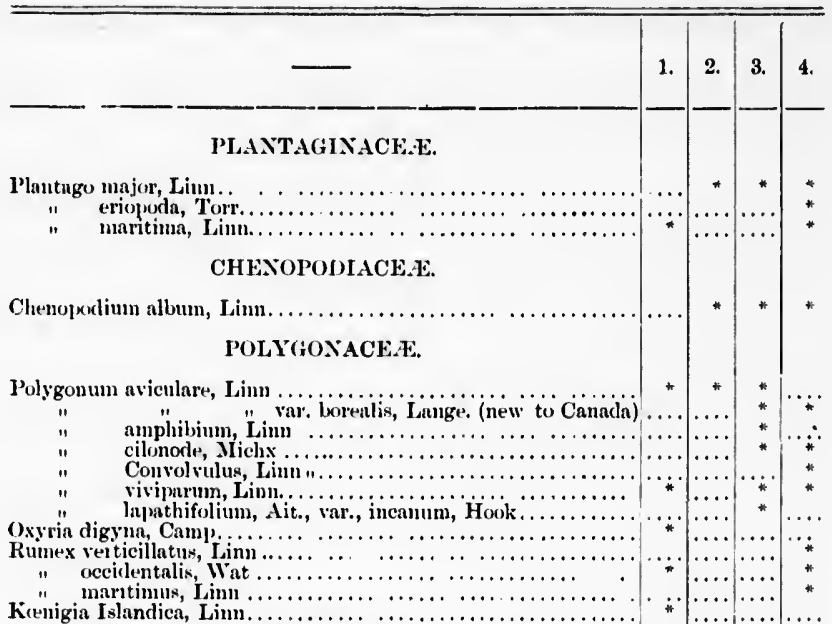

ELEATSACEX.

Eleagnus argentea, Pursh..

Spehfherdia Canademsis, Nutt.

SANTALACE.E.

Comandra livida, Rich....

UR'TICACE.l.

Urtica gracilis, Ait

\section{MYRICACE,}

Myrica Gale, Limm.

BETLLACF.'.

Betula Juten, Michx

- papryifera, Micli.

" punila, Lim.

" glandulosa, Mich.

naua, Linm.

Alnus incena, Wilid. viridis, DC.

\section{SAIICACEA}

Salix ademophylla, Hook . arctica, R. Br.

argyrocarpa, Auders.

bal wamifera, Bairatt .

candicia, Willd.

chlurophrlla, Anders.

cordata, Muhl.

cexertorum, Ricl

incolor, Mulil. 


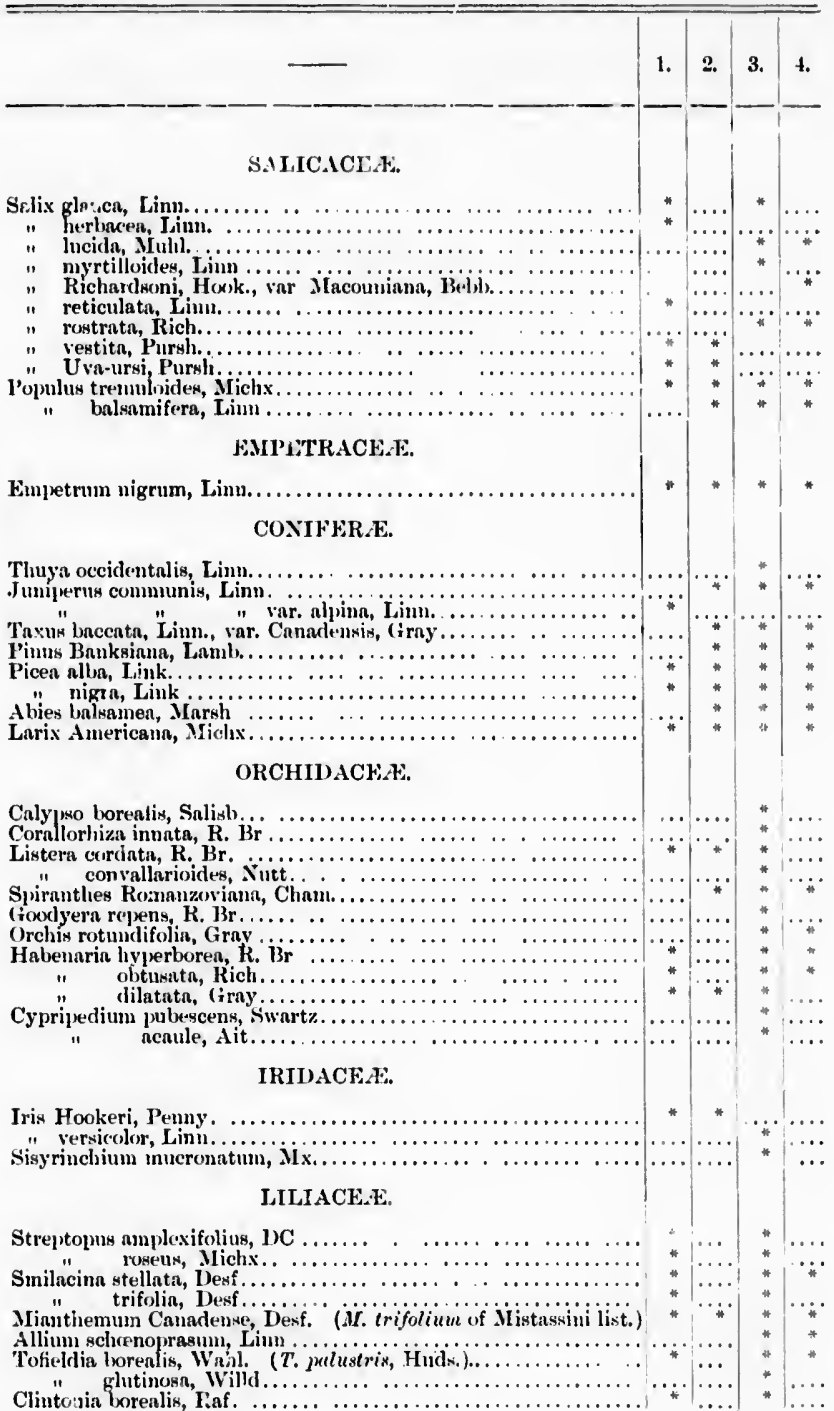




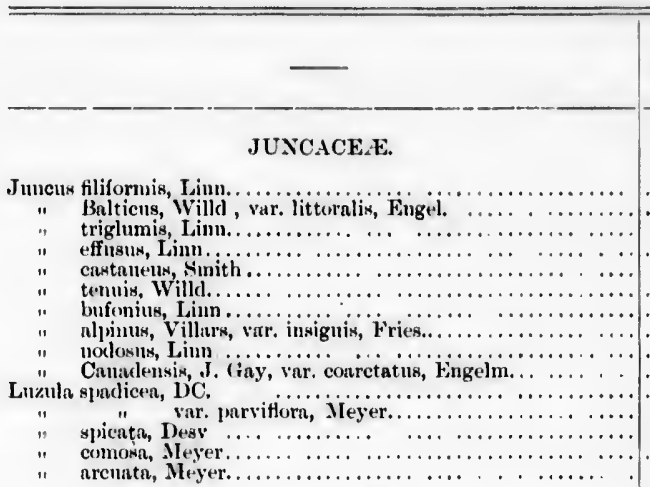

\section{TYPHACEE.}

Sparganimu simplex, Huds.

hyperlkoleum, Liest., var. Americanum, Beeby.....

AROII)E.E.

Calla palustris, Linu

LEMXALEF.

Lemna minor, Limn.

ALISMACE.E,

Sagittaria variabilis, Engelm

\section{NAID.ACE.E.}

Trigluehin palustre, Limn .

potanoge ton heterophylluw, sclireb. (Incindes two varieties of $P$. gramineus in Mlistassin: list.).

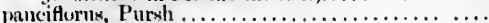

lectiuntuin, Thim

marinus, Linn...

perfoliatus, Linn

jusilhus, Linn ...

rutilans, Wolfgan

rufescens, Sichrad.

Daian flevilis, Kontk

Zannichollia palustris, Limn.

\section{CXPERACE.E.}

Eleocharis pelustris, R. Br.

Scirups lacustris, Linn. (S. melidus, Valıl.) sylvaticus, Linn., var, digguus, Bueck. (S, microcurpus, Presl.).

cespitosus, Linn

atrovirens, Inhl.

Eriophurum alpimum, Linn....

cyl criamm, Limn

vaginatum, Liun

russeolum, Fries.

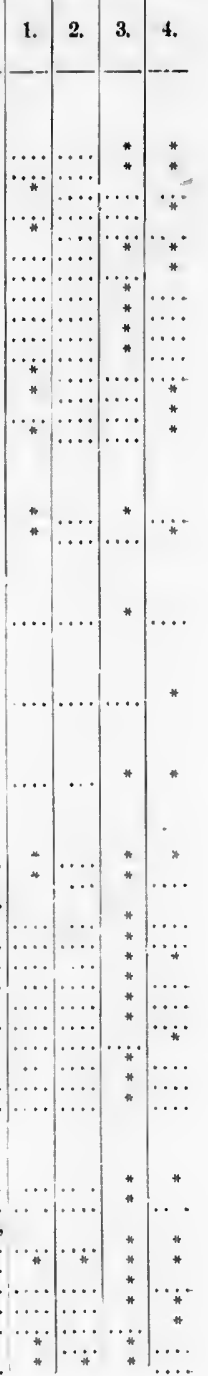




\begin{tabular}{|c|c|c|c|c|c|}
\hline & & 1. & 2. & 3. & 3. \\
\hline \multicolumn{6}{|c|}{ CYl'bIAL'sis-Continned. } \\
\hline \multirow{2}{*}{\multicolumn{2}{|c|}{ 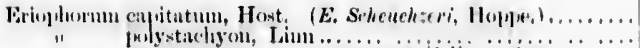 }} & * & 4 & & $\star$ \\
\hline & 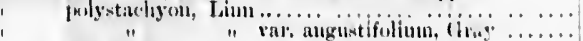 & $\cdots$ & & & $\ldots \ldots$ \\
\hline & 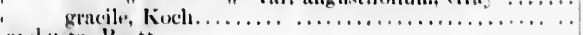 & & $\cdots$ & $\because$ & . \\
\hline atex & 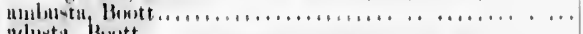 & & & $\because \cdot$ & \\
\hline " & 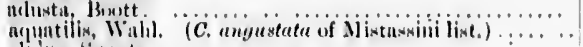 & $\cdots \cdots$ & $\cdots$ & * & 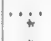 \\
\hline " & "lilm, Swart\%......... & & & $\because *$ & * \\
\hline$\ddot{\prime \prime}$ & 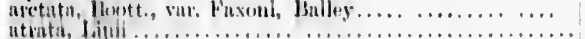 & & & * & \\
\hline$"$ & 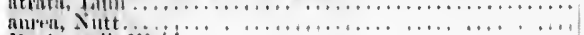 & & & * & $\because$ \\
\hline$"$ & linxbanmii Wablil. ... & & & * & \\
\hline$" 1$ & 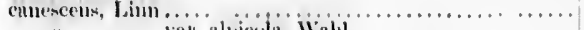 & & & 4 & \\
\hline$"$ & " " vas, alpicola, Wa & . & & $\stackrel{*}{*}$ & \\
\hline$" 1$ & 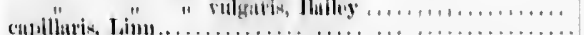 & $\cdot$ & $\cdots$ & * & \\
\hline$" 1$ & & $\cdot$ & & * & \\
\hline "1" & 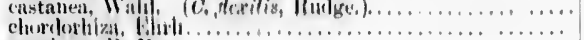 & & & * & \\
\hline$\ddot{11}$ & 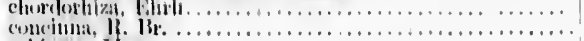 & & & \# & \\
\hline$"$ & 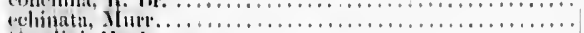 & & & * & \\
\hline$" 1$ & 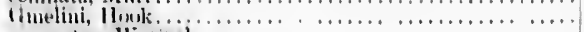 & & & & \\
\hline " & gyucrates. Wirinsk............... & & & $\ldots$ & ":" \\
\hline$" 1$ & 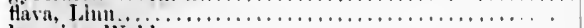 & & & $\cdots *$ & \\
\hline$" 1$ & lagıриiuta, $\|$ ahl................ & & & & \\
\hline$"$ & 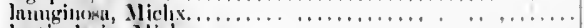 & & & & \\
\hline 11 & 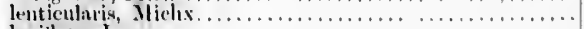 & & & & \\
\hline$"$ & 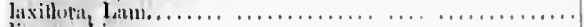 & $\ldots$ & & 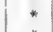 & \\
\hline$" 1$ & 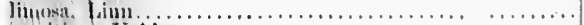 & $\ldots$ & & * & \\
\hline " & 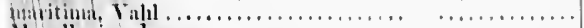 & & & & \\
\hline$" 1$ & 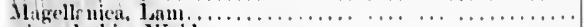 & & & * & \\
\hline$"$ & mictoglochin, linhl $\ldots \ldots, \ldots \ldots \ldots, \ldots \ldots$ & & & & \\
\hline " & 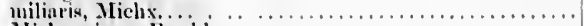 & & & & * \\
\hline "1 & 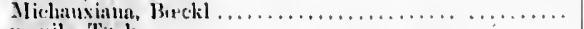 & & & \# & \\
\hline "1" & monile, Tuck....................... . $\ldots \ldots$ & & & * & * \\
\hline$"$ & 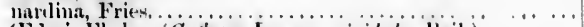 & & & & \\
\hline 11 & 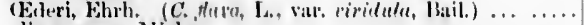 & & $\ldots$ & & * \\
\hline 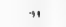 & 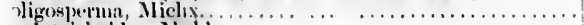 & & & * & \\
\hline$" 1$ & 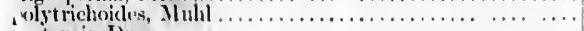 & & $\cdots$ & * & \\
\hline$"$ & 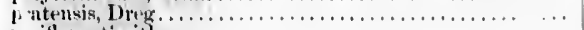 & & & & \\
\hline " & m, Sinth,$\ldots \ldots \ldots \ldots \ldots \ldots \ldots \ldots \ldots$ & & & $\cdots$ & \\
\hline$" 1$ & 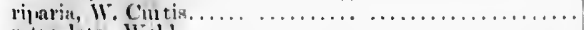 & $\cdots \cdots$ & & $\cdots$ & \\
\hline$"$ & idata, Walıl........ , . . . . . . . . & & $\cdots$ & $\ldots$ & \\
\hline$" 1$ & 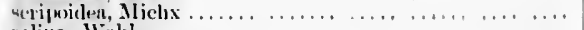 & $\because *$ & & & \\
\hline$"$ & 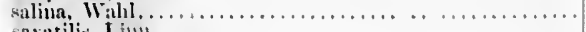 & & & & \\
\hline$"$ & 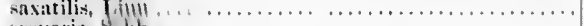 & $\cdots$ & & . & \\
\hline$"$ & 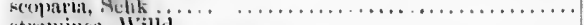 & & & & \\
\hline$" 1$ & $\ldots \ldots \cdots \cdots$ & & . & & \\
\hline$"$ & ; decora, Bail... ... ....... & • & $\cdots$ & $\because$ & \\
\hline$" 1$ & a. Good. . $\ddot{\text {. }}$ & . & $\cdots$ & * & \\
\hline$"$ & til, Buott. (C. & & & * & \\
\hline & 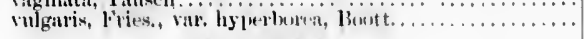 & * & * & & \\
\hline & fil & & & & \\
\hline. $\mathrm{el}$ & orus, Sicrib........... & & & * & \\
\hline is & $\ldots \ldots \ldots \ldots \ldots \cdots \cdots$ & & & & * \\
\hline & inu............. & & 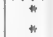 & * & \\
\hline & $\ldots \ldots \ldots \ldots \ldots \ldots \ldots$ & & & & \\
\hline
\end{tabular}




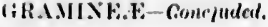

Stipa IReharilemii, Jink. .

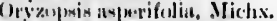

Jhilumu pratense, Linn

$$
\text { "1pinmm, Jimin }
$$

Agrostion sealori. Willd

('iimu jendula, 'Trin.

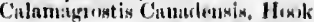

$$
\text { Inglects, kiunth... }
$$

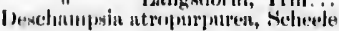

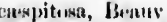

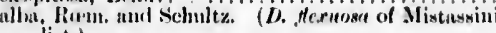
list.)

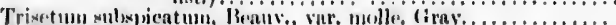

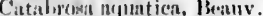

I'แ *lpina, fim

ecesia, sinith

( cenixil, All.

"s chumuris, Trin

iontensis, Jinu.

(i) vec ria Canadensin, Trin.

anuelimeser, Kinth.

urivatu, 'lin.

Fistuca ovinu, Jum o...

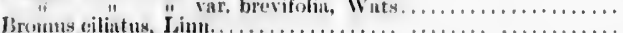
Igreilyrum tenerum, Vouv.

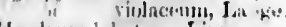

flordentm juhtum, Jimn...

Filymus mollis, Trin

\section{EQUISFIOAFE}

Erquisetum arvenss, Jim

Iratanke, Jing!. . .

vyaticum, Jinn .

pulustre, limm.

scir|xides, Michx.

\section{OPIIOKIJOSSACE.T.}

Dintrychinu I,marla, Swarts.

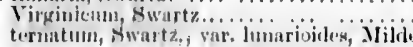

\section{FIICES.}

Piulyporlimm yulgare, I inu.

Pe.tien gracilis, Hoxk.

l'toris anilima. Jimm

Isplenimum viricte. Ifuls.

Folis-formim, Bionl

['hengunteris Heyontaris, Fete.

poly podicicles, F'e.

Rolnetianum, Dav, (P), cetcures,

Apridium spunulosum, swart\%, var, dilatatim, Hicoli.

Onnclea sensibiliv, Linn...

Cystopteris fragilis, Bernli

$$
\text { montani, Berwh. }
$$




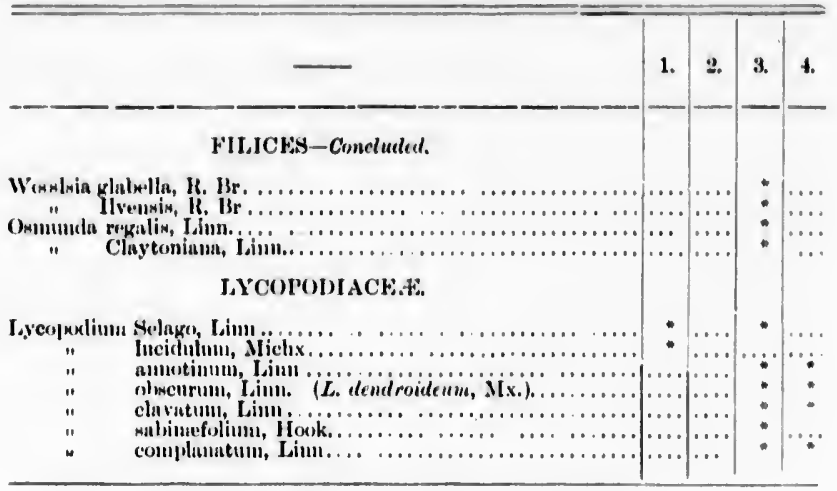




\section{APPENDIX VII.}

Meteonological Ouservations in tue Lamrador Penissula, 1893 1894 and 1895 HY D. I. V. Eato.

The barometer used was a small aneroid, but the readings have been corrected, and are believed to be nearly exact.

The temperature is stated in degrees Fahrenheit.

The force of the wind is estimated according to a scale from 0 to 5 .

The proportion of the sky covered by clouds is estimated by a scale from 0 to $10 ; 0$ being a cloudless sky, 10 a completely clouded sky. The cliarncter of the clouds is denoted by the usual letter or combination of letters referring to Howard's classification.

The letters used in the last column have the following designations : B. blue sky ; C. cloudy ; R. ruin; G. gloomy; F. fog; O. overcast ; H. haze.

Note-The observations tuken between 20th June and 13th August, 1893, were lost through the upset of a canoe. The last thernometer was broken on 18th June, 1894. 
A P P EN

Meteorological Onservatioss in the

\begin{tabular}{|c|c|c|c|c|c|c|c|c|}
\hline \multirow[t]{2}{*}{ Place. } & Date. & \multicolumn{3}{|c|}{ Thermometer. } & \multirow{2}{*}{$\stackrel{\Xi}{\stackrel{\Xi}{\Xi}}$} & \multicolumn{3}{|c|}{ Baroneter. } \\
\hline & $18 \div 3$. & 7 & 2 & !) & & T & 2 & $\because$ \\
\hline Kaniapueskatu Lake.. & 111. 14. & 31 & 70 & (il & & $28 \cdot 11 i$ & $28 \cdot 16$ & $28 \cdot 1 !$ \\
\hline 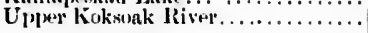 & $19, \ldots$ & 58 & (iij) & 61 & & 28.19 & 20 & 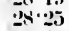 \\
\hline ............................... & " 16 & 50 & 70 & $\therefore$ & & $2 \times-21$ & 28.35 & and \\
\hline 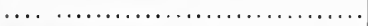 & " 17. & 40 & 75 & 65 & ... & $2 x \cdot 4 k$ & $2 \times \cdot 54$ & $28 \cdot(i 2$ \\
\hline & "18.. & 50 & $i^{5}$ & (ii) & & $25 \cdot 192$ & 27 & או! \\
\hline Koksoak River $\ldots \ldots$, ........... & " is.. & 331 & itis & in & $\ldots \ldots$ & $\because 4 \cdot 013$ & all 11 & 2019 \\
\hline 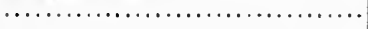 & $1 \quad 20$ & in! & 75 & 62 & $\ldots$ & 2917 & $2 ! \cdot 23$ & 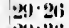 \\
\hline$\ldots \ldots \ldots, \ldots, \ldots, \ldots, \cdots$ & " 21 & 54 & (is & it & $\cdots$ & 24 & $21 \cdot 11$ & $2: 3 \cdot 31 j$ \\
\hline 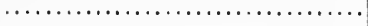 & " 222 & 44 & $\because 2$ & (6).5 & .. & 2!) $3 !$ & $-31) \cdot 15$ & $21 \cdot 20$ \\
\hline 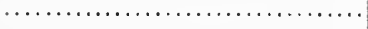 & " 23. & 192 & 53 & in & -5 & $29 \cdot 16$ & $2 ! 14$ & $2(2) \cdot 0 !$ \\
\hline 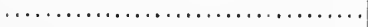 & "24. & (ii) & ti3 & i5) & & & $.29 \cdot 30$ & $2 ! 1 \cdot 4 !)$ \\
\hline 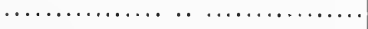 & " $\mathbf{2 5}$. & 38 & 6.t & $5 \%$ & $\ldots \ldots$ & $29 \cdot+4 i$ & 211.44 & $2 ! 1 \cdot 54$ \\
\hline (n) & " 20:- & lit & (ji) & 5li & $\cdots$ & $2 ! 1 \cdot(6 !)$ & 2y) it & 20148 \\
\hline 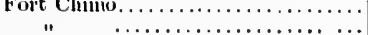 & " $2 \pi$ & 5 & 30 & lit & $\cdots \cdots$ & 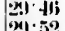 & $2 ! 1 .+1$ & $3 ! 1 \cdot 50$ \\
\hline (n) & "1). & (ij & 2 & in & $\therefore \cdots$ & 40 & 20.84 & 副.!14 \\
\hline .................... & " 314. & is & 42 & 40 & ?.... & 89 & 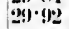 & 6!1 192 \\
\hline 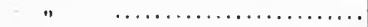 & " 31. & 46 & & \pm & $\ldots$ & 29) $\cdot \times 1 ;$ & & 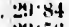 \\
\hline ................. & Sepit. 1. & $4 i j$ & 66 & i) & ..... & 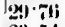 & 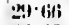 & ; \\
\hline$\ldots \ldots \ldots, \ldots \ldots \ldots \ldots \ldots$ & 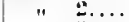 & 4!) & 72 & 5li & $\ldots$ & $29 \cdot 54$ & $21 \cdot 42$ & $\underline{-9}+42$ \\
\hline $\ldots \ldots, \ldots, \ldots, \ldots, \ldots, \ldots$ & 113. & 54 & 50 & 4) & & 29 & (3) $4(35$ & $2(1 \cdot 5)$ \\
\hline$\ldots \ldots \ldots \ldots \ldots \ldots \ldots \ldots, \cdots$ & 4. & 10 & (61) & 47 & 32 & 29 & 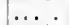 & $21+44$ \\
\hline$\ldots \ldots \ldots+\ldots, \ldots+\ldots, \ldots$, & $"$ & 50) & 54 & 50 & 42 & $2 ! \cdot 40$ & $2: 1 \cdot 3 ! 1$ & 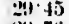 \\
\hline . & ij. & $4 i \mathrm{i}$ & $4 s$ & 48 & & $2 ! \cdot 165$ & $2 ! 1 \cdot 72$ & 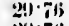 \\
\hline ............ & $"$ & ti) & 54 & 40 & to & 24184 & $291 \times 82$ & $2 ! 1 \cdot 7 i$ \\
\hline ..... & 18. & +2 & sit & $3 k$ & 33 & $29 \cdot 7 !$ & $2 ! 1 \cdot 83$ & $2 ! 1 \cdot 31 j$ \\
\hline & & $31 i$ & t5 & 38 & & $2918 !$ & 290 & $2 ! ! ! ! 1$ \\
\hline Uugava Bay... & 110. & 3.) & 54 & & & (4) $\cdot 92$ & 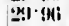 & $2 !) \cdot ! 14$ \\
\hline (Gerorge River l'oust.................. & $" 11$. & 42 & H & 12 & $\cdots$ & $30 \cdot($ M) & 3004 & $311 \cdot 04$ \\
\hline " $\quad$. & $" 12$. & 54 & $5 \mathrm{~s}$ & (5) & (..... & $2 ! \cdot 1$ lit & $2 !) \cdot 64$ & $2 ! 1 \cdot+1$ \\
\hline & " 13 & 55 & & 54 & .. & $29+11$ & ..... & . $2: 3 \cdot 54$ \\
\hline Ungava Bay. & 114 & (ii) & .... & $4 \times$ & & $29 \cdot 42$ & & $.29 !+40$ \\
\hline (n................ & " is & ts & ....... & $\$ 3$ & ... & $29 \cdot 14$ & ... & 30102 \\
\hline "1. . & " 16 & $3 \mathbf{j}$ & ... . & 43 & ... & $2 ! 1 \cdot 4$ & $\cdots$ & . \\
\hline .................. & $" 17$. & iti3 & ....... & (b4 & & $29+72$ & . & $2 !) \cdot 62$ \\
\hline & $" 18$. & 132 & {$[\ldots \ldots$} & & $\ldots$ & $21) \cdot 62$ & $\cdots \cdots$ & $\cdot \cdots$ \\
\hline Ungava Bay $\ldots \ldots \ldots \ldots \ldots \ldots \ldots \ldots$ & $" 19 \ldots$ & 55 & L & & $\cdots \cdots$ & 29! ( & 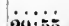 & \\
\hline 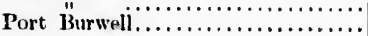 & $" \begin{array}{ll}201 \\
21\end{array}$ & +3 & $\ldots$ & $\begin{array}{l}50 \\
43\end{array}$ & $\cdots$ & (3). 18 & 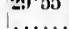 & 20.64 \\
\hline$\cdots \cdots \cdots$ & $" 22$. & 45 & & 40 & $\because$ & $2 ! 1 \div 0$ & & . 61 \\
\hline & " 23 & 40 & & 42 & .. & 295 & & 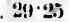 \\
\hline Nachsak Bay $\ldots \ldots \ldots \ldots \ldots \ldots \ldots$ & " 24. & 42 & .... & 40) & .... & $24-17^{2}$ & ... & . 23) 40 \\
\hline n........... & " 25 & tij & ........ & 4I) & $\cdots$ & 291.15 & r. & . 24) 20 \\
\hline Davis Inlet . & " 27. & 45 & $\cdots$ & $\begin{array}{l}10 \\
38\end{array}$ & $\cdots$ & $29 \cdot 64$ & & . \\
\hline
\end{tabular}




\section{X V I I-(Cont.)}

Labrador Peninsula, 1893-1894.

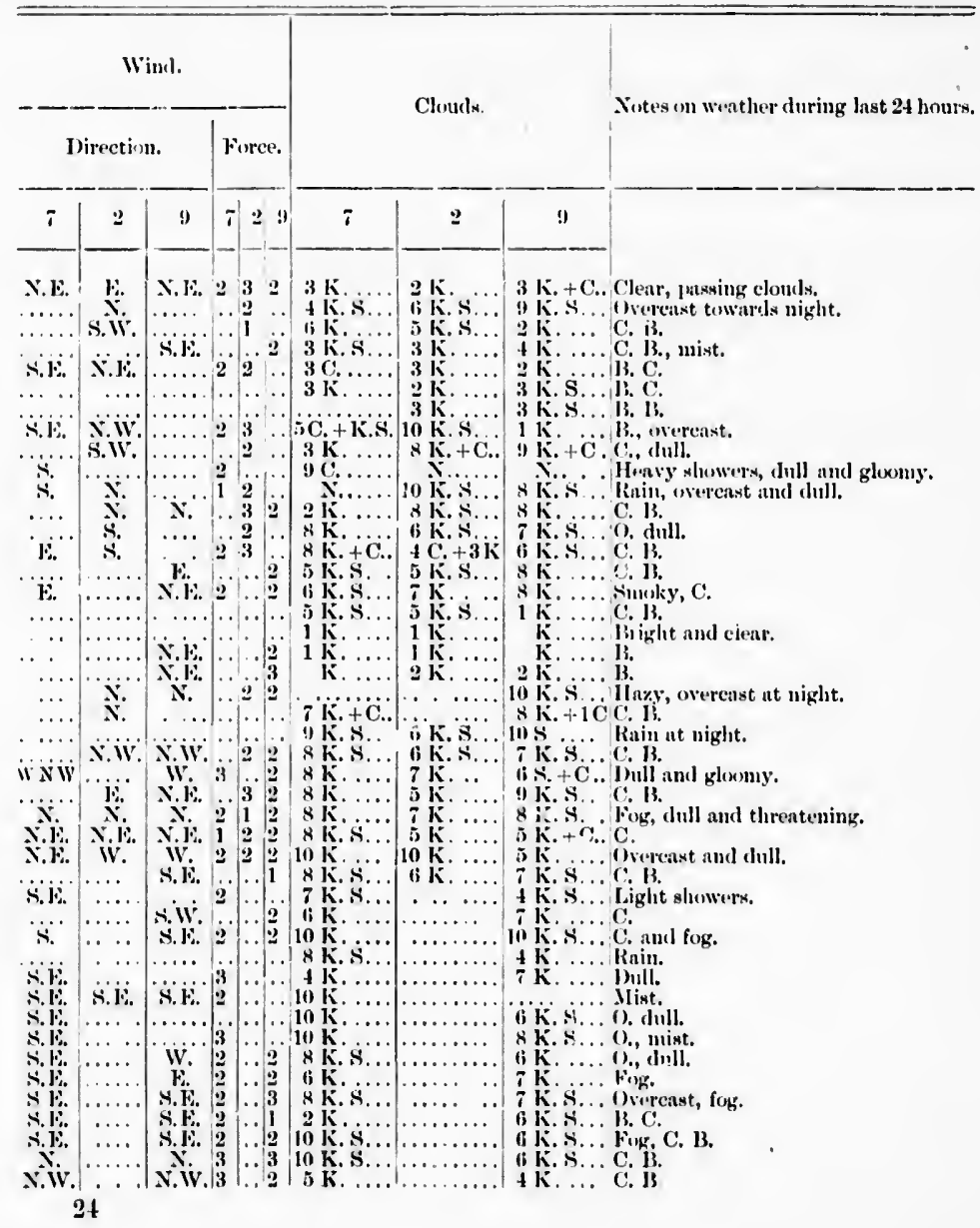


Meteorological Obsemations in the
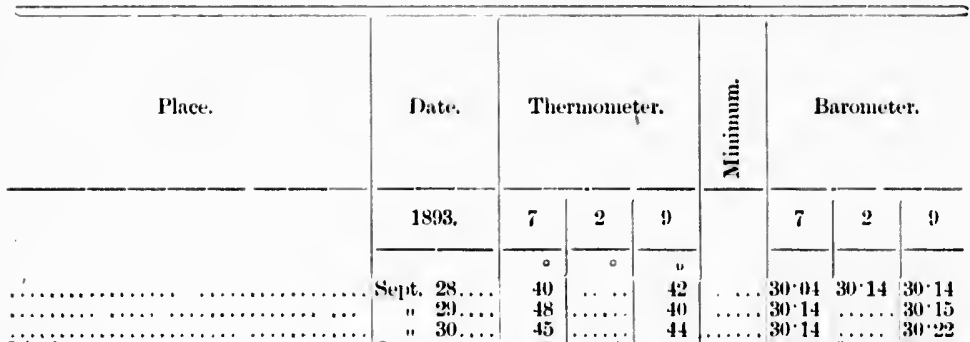

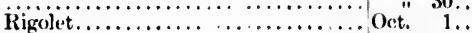

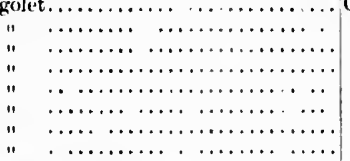

Hämilton Injet

Northwest River, Laibrador

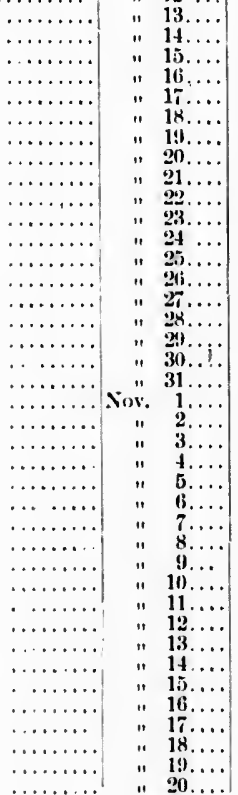

.....

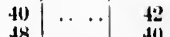

$\ldots 30 \cdot 114: 31) \cdot 14(30 \cdot 14$

$48 \quad \ldots \ldots+40 \quad \ldots \ldots 30 \cdot 14 \ldots \ldots 30 \cdot 15$

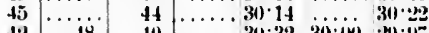

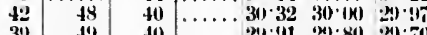

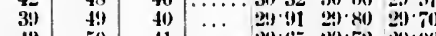

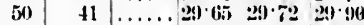

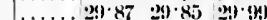

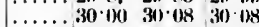

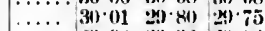

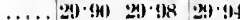

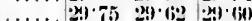

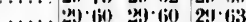

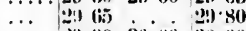

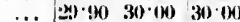

$\ldots \ldots(31) \cdot 20 \quad 31) \cdot 12 \quad 30 \cdot 12$

$\ldots \ldots 2) \cdot(10)$

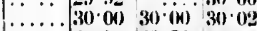

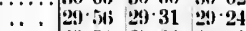

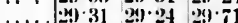

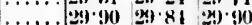

$\ldots \ldots \ldots+10 \quad 30 \cdot 12 \quad 30 \cdot 20$

$\ldots \ldots(30 \cdot 20330 \cdot 12$ :31.145

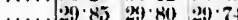

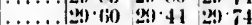

$\ldots \ldots 3 t \cdot 10 \quad 30 \cdot 15 \quad 31) \cdot 41$

$\ldots \ldots 30 \cdot 70 \quad 31 \cdot 10 \quad 31 \cdot 40$

$\ldots \ldots .30 \cdot 22 \quad 30 \cdot 05 \quad 24) \cdot(4$

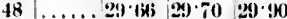

$43 \ldots \ldots .30 \cdot 00$ 31 $1130 \cdot 20$

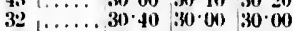

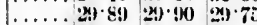

4) (32 $94 \cdot 41 \cdot 41 \cdot 41$

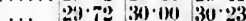

$\begin{array}{llll}\ldots & 30 \cdot 32 & 30 \cdot 40 & 30 \cdot 23\end{array}$

$\ldots .31 \cdot 20 \quad 30 \cdot 10 \mid 30 \cdot 08$

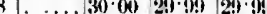

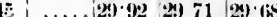

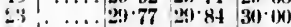

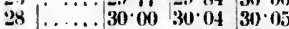

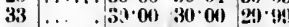

$32 \quad \ldots \ldots 3016 \quad 3 \cdot 2430 \cdot 00$

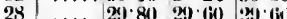

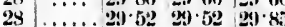

$14 \ldots .30 \cdot 04 \quad 30 \cdot 10 \quad 31 \% \cdot 12$

$14 \ldots .30 \cdot 20) 30 \cdot 10 \quad 30 \cdot 20$

$24 \ldots \ldots 30 \cdot 2030.21) 31.11$

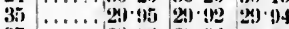

37 ...

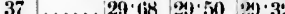

(2)

$92 \quad \cdots \cdots \cdot 2,10$ (2)

$\ldots \ldots .24 \cdot 44$ (4) 31 , औ)

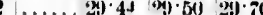


Labrador Peninsula, 1893-1894-Continued.

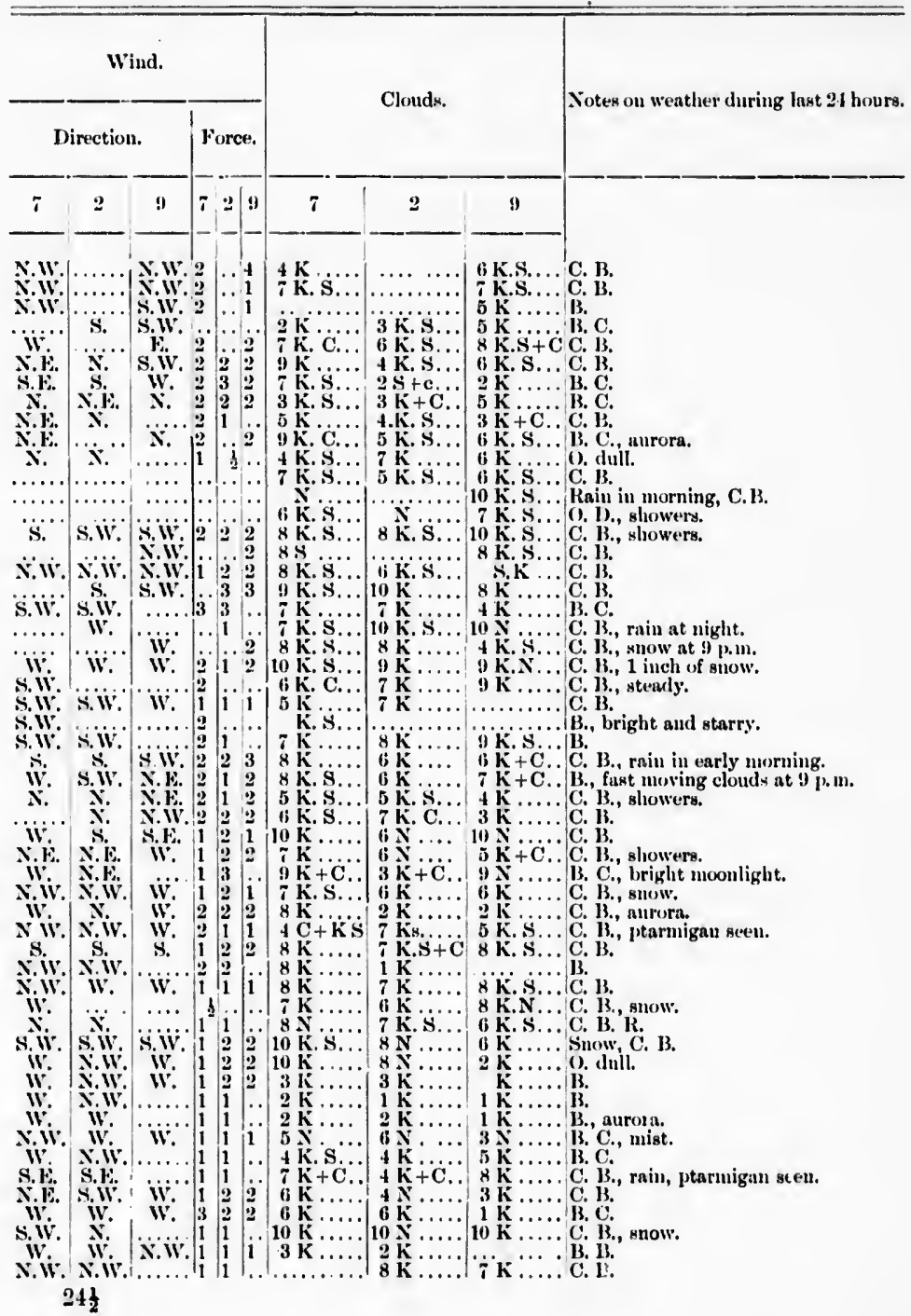


Meteorolorical Onseivations in the

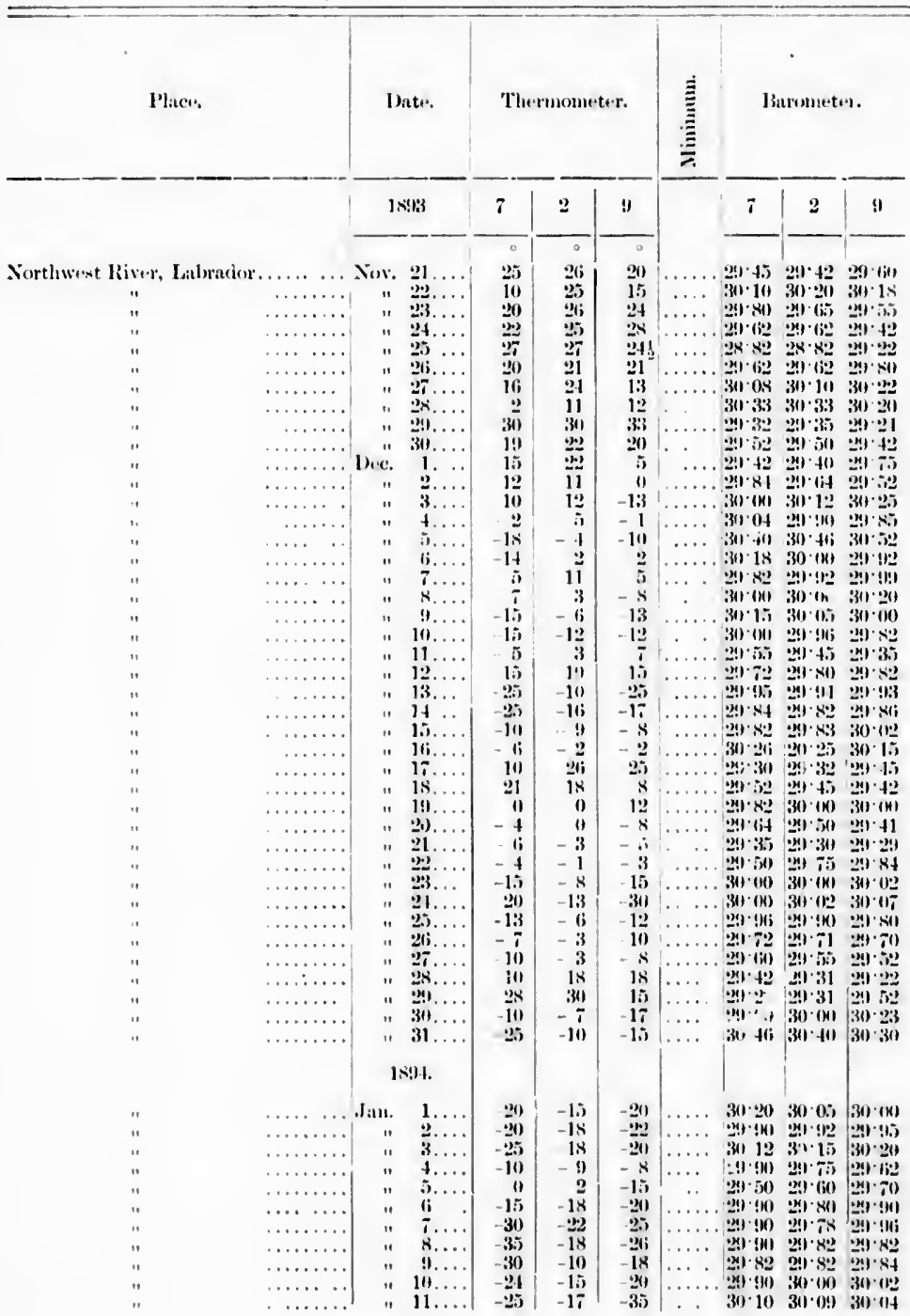


Latrador Peninsula, 1893.1894-Continued.

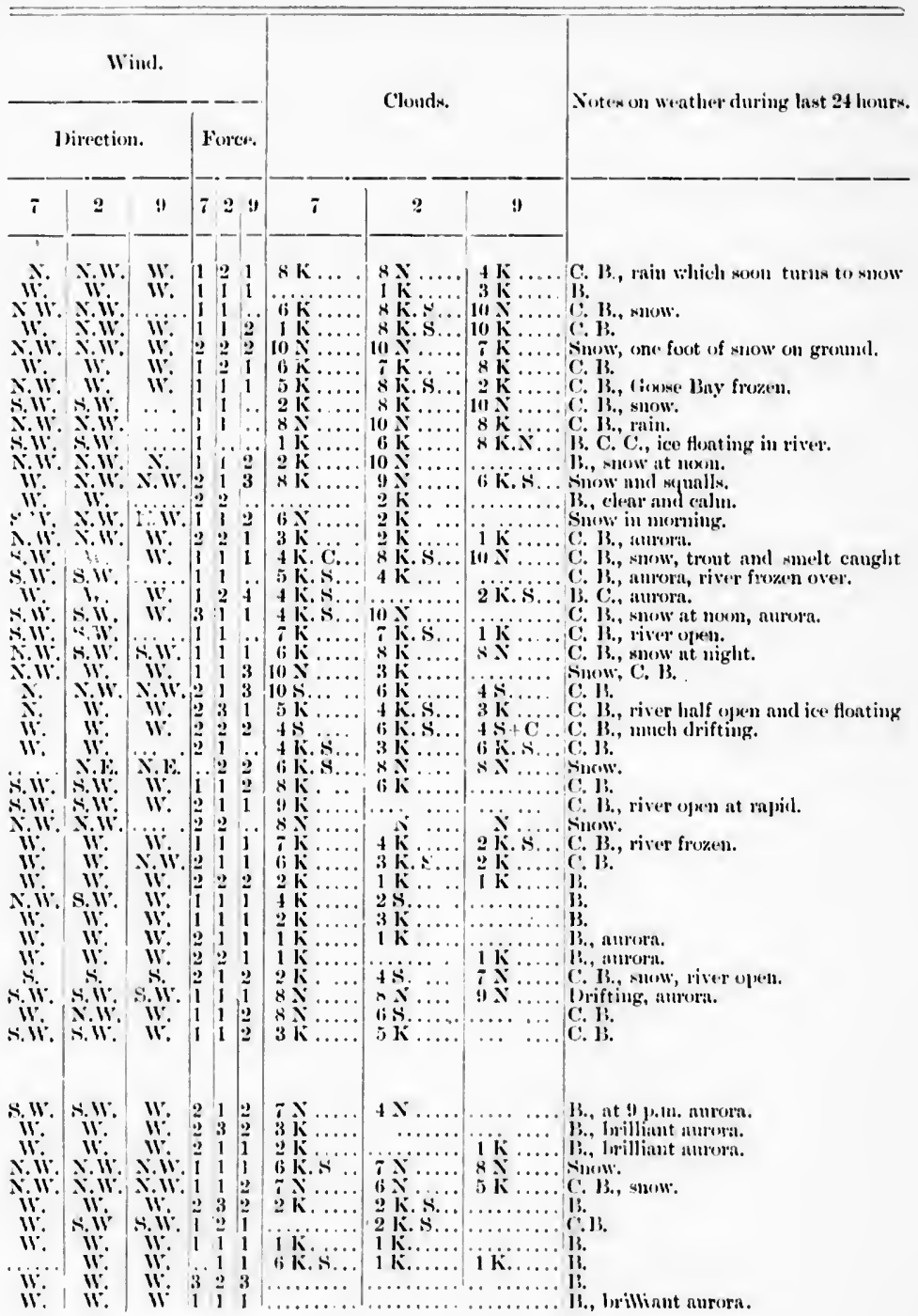


Meteorological Observations in the

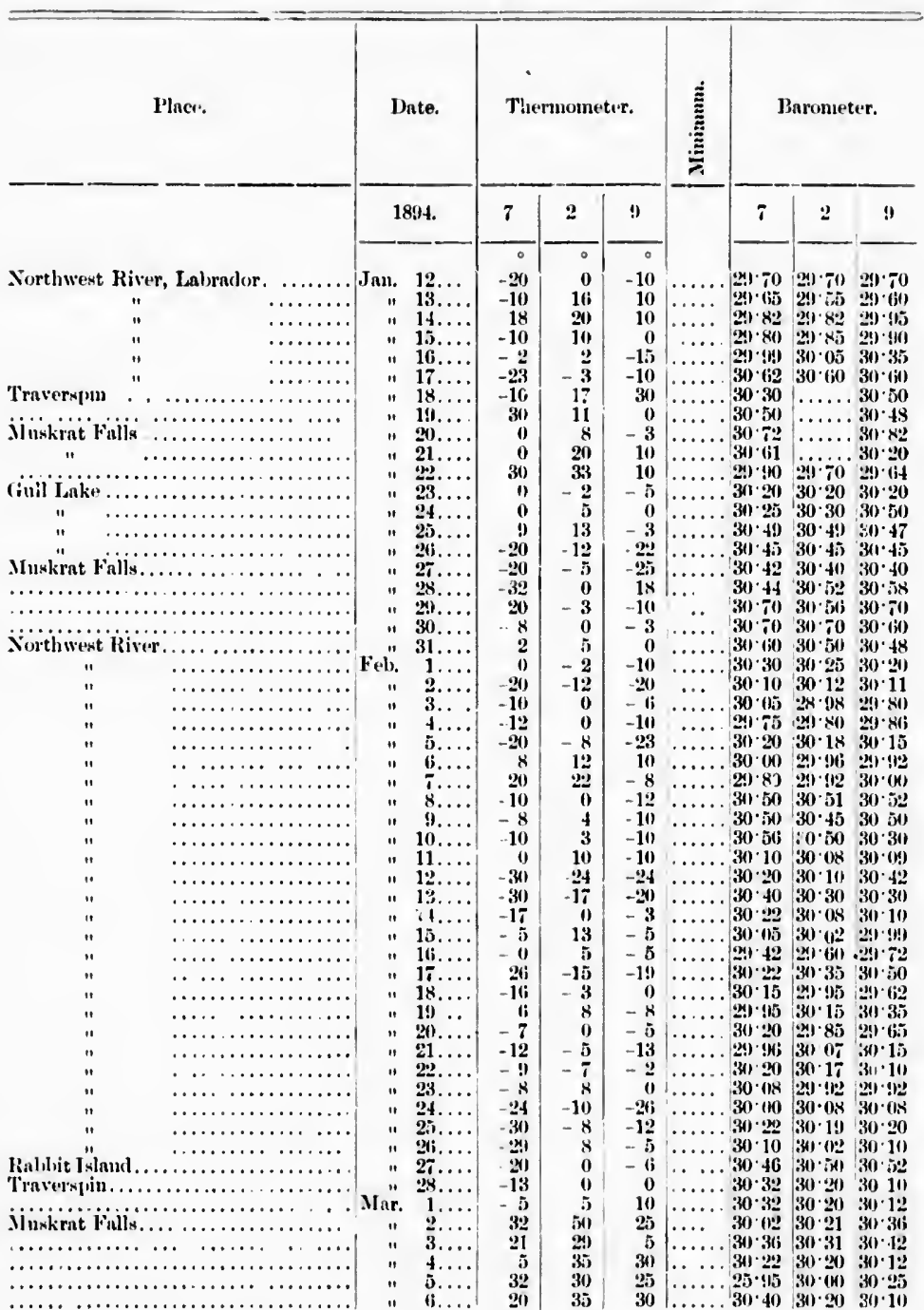


Labrador Peninsula, 1893-1894-Continued.

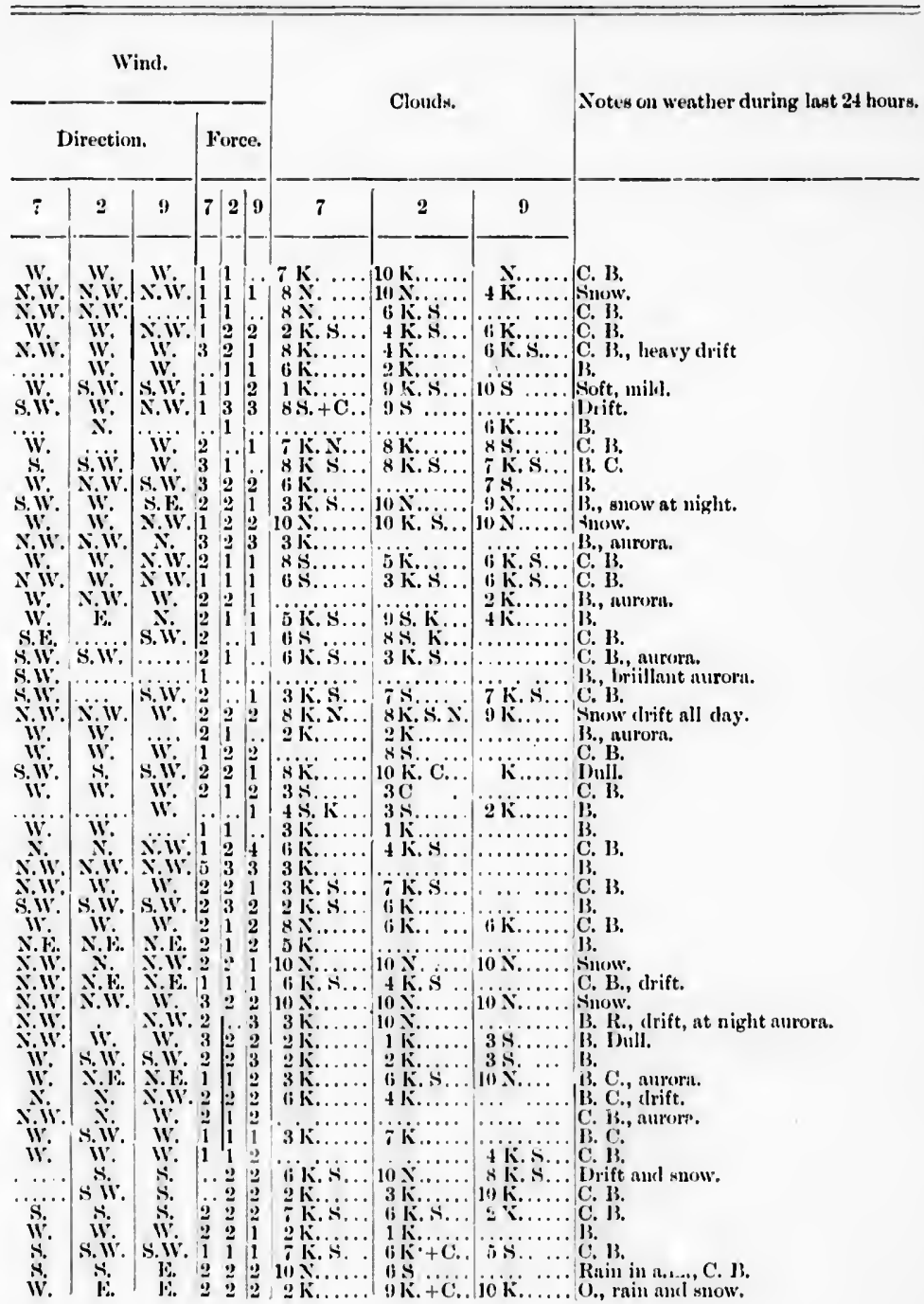


11. TeOnot. ical Onenvaticss in the

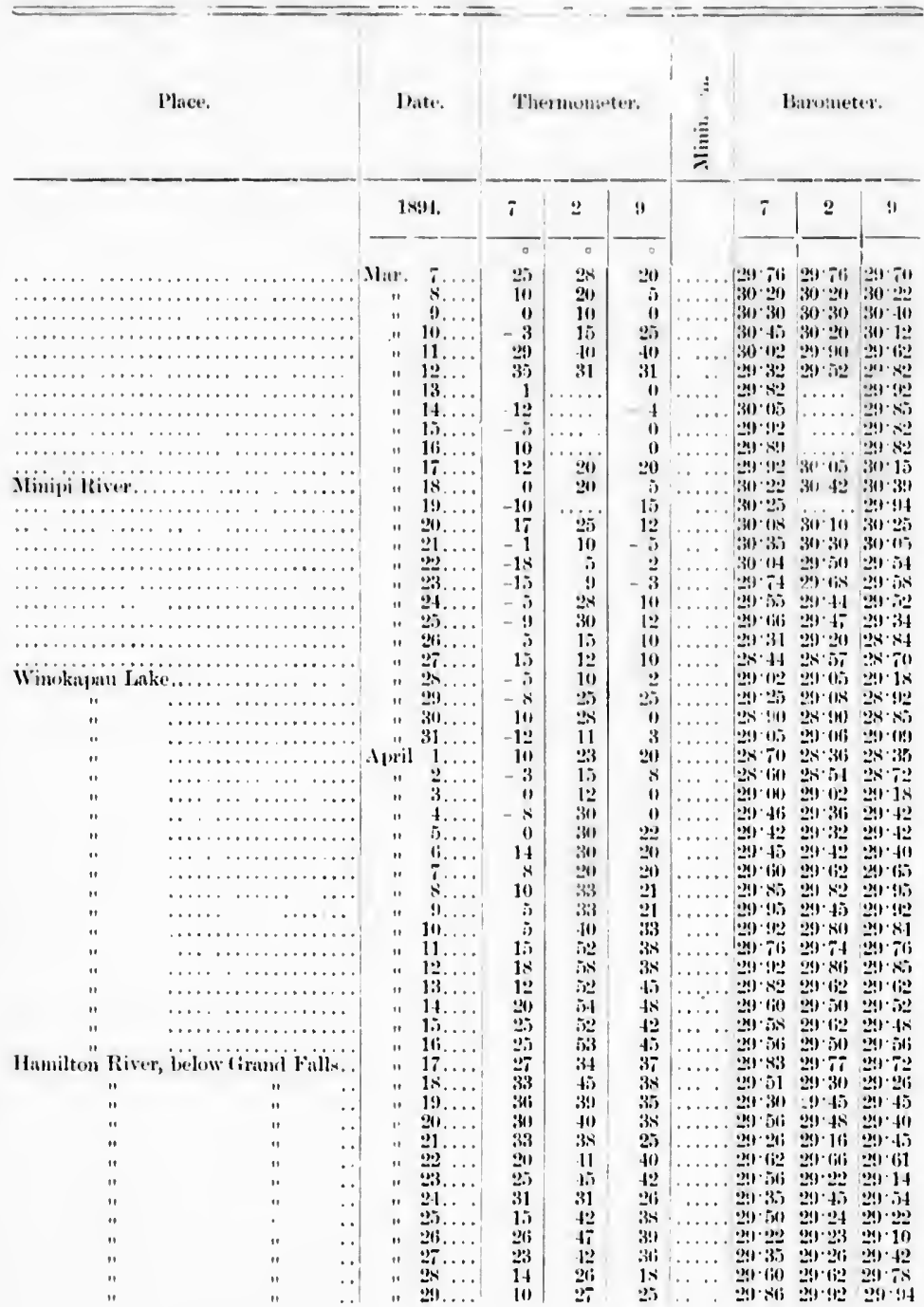


Jabridor Peninsula, 1893-1894-Contimed.

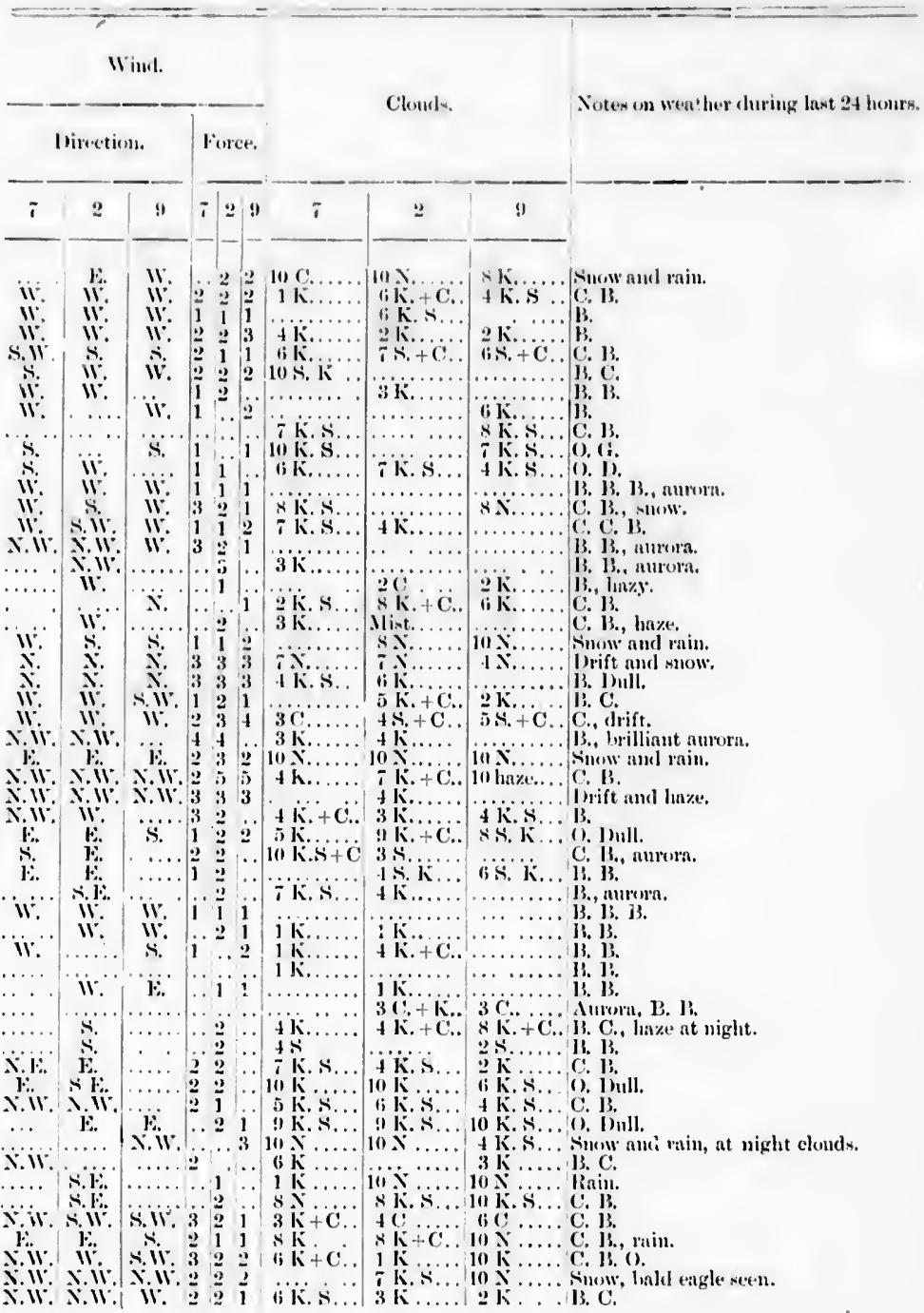


Metrorolomical Ohservations in the

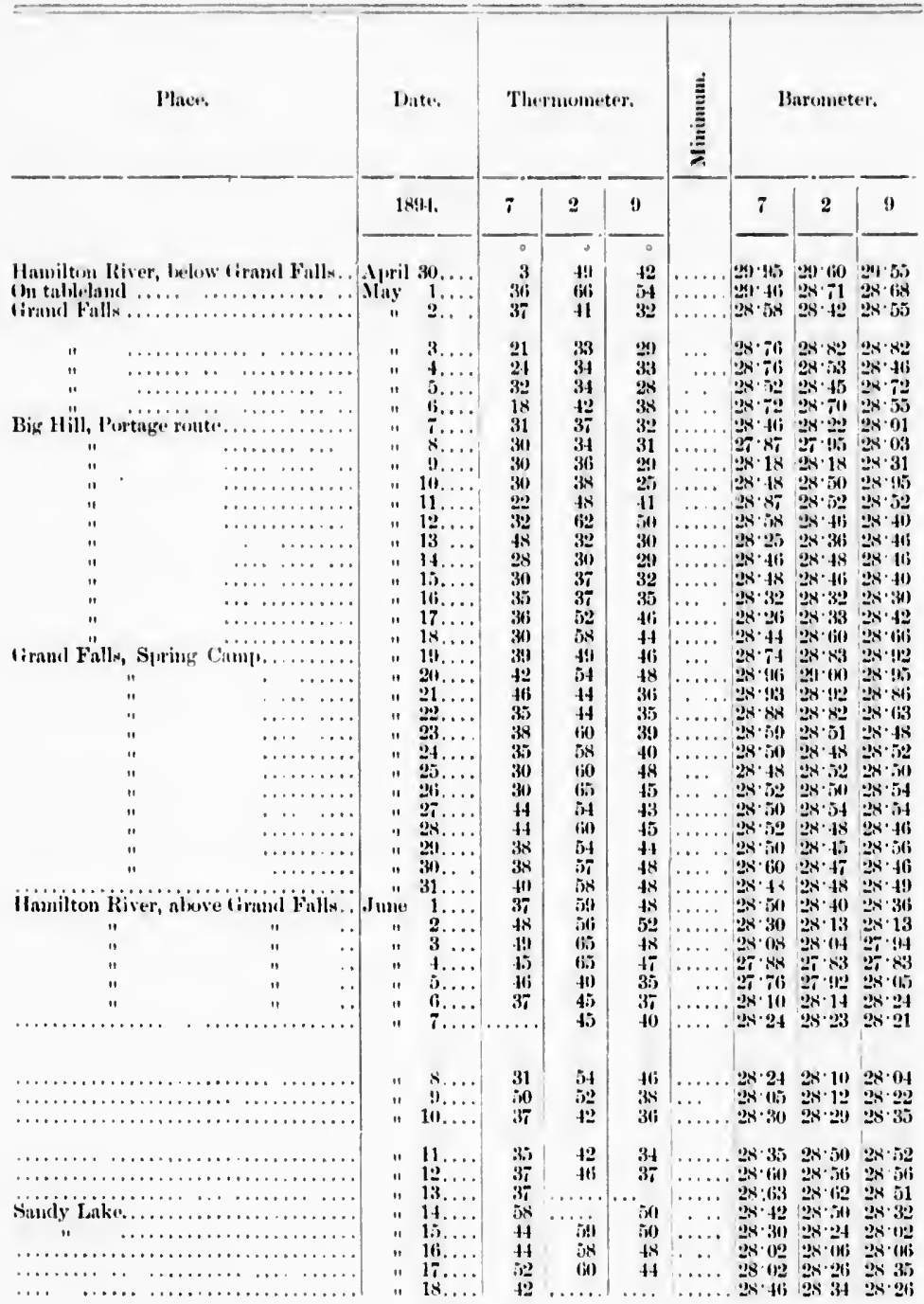


Labrador Peninsuln, 1893-1894.-Continuet.

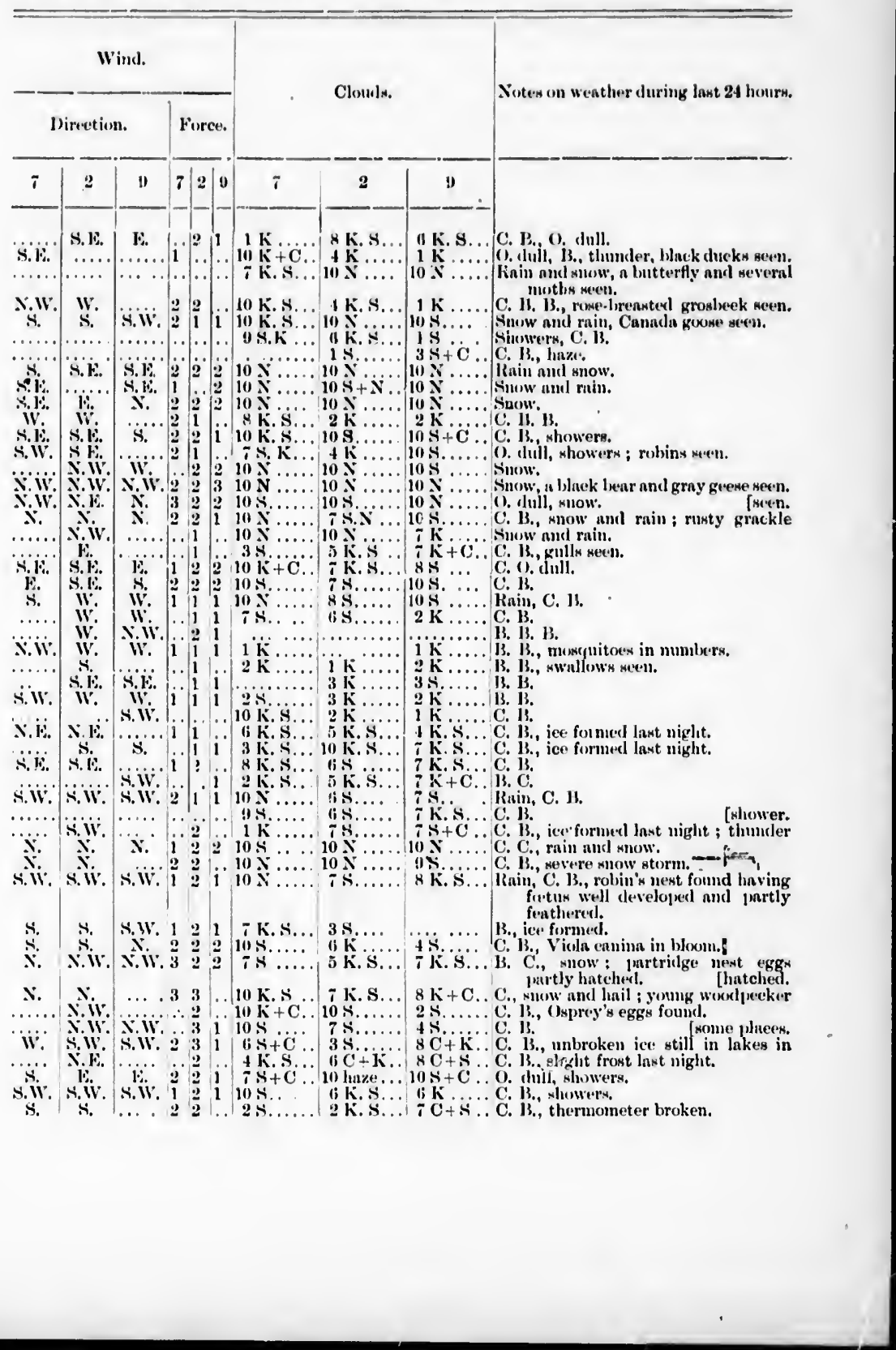


Metronotonical. Uhanswatioss in the

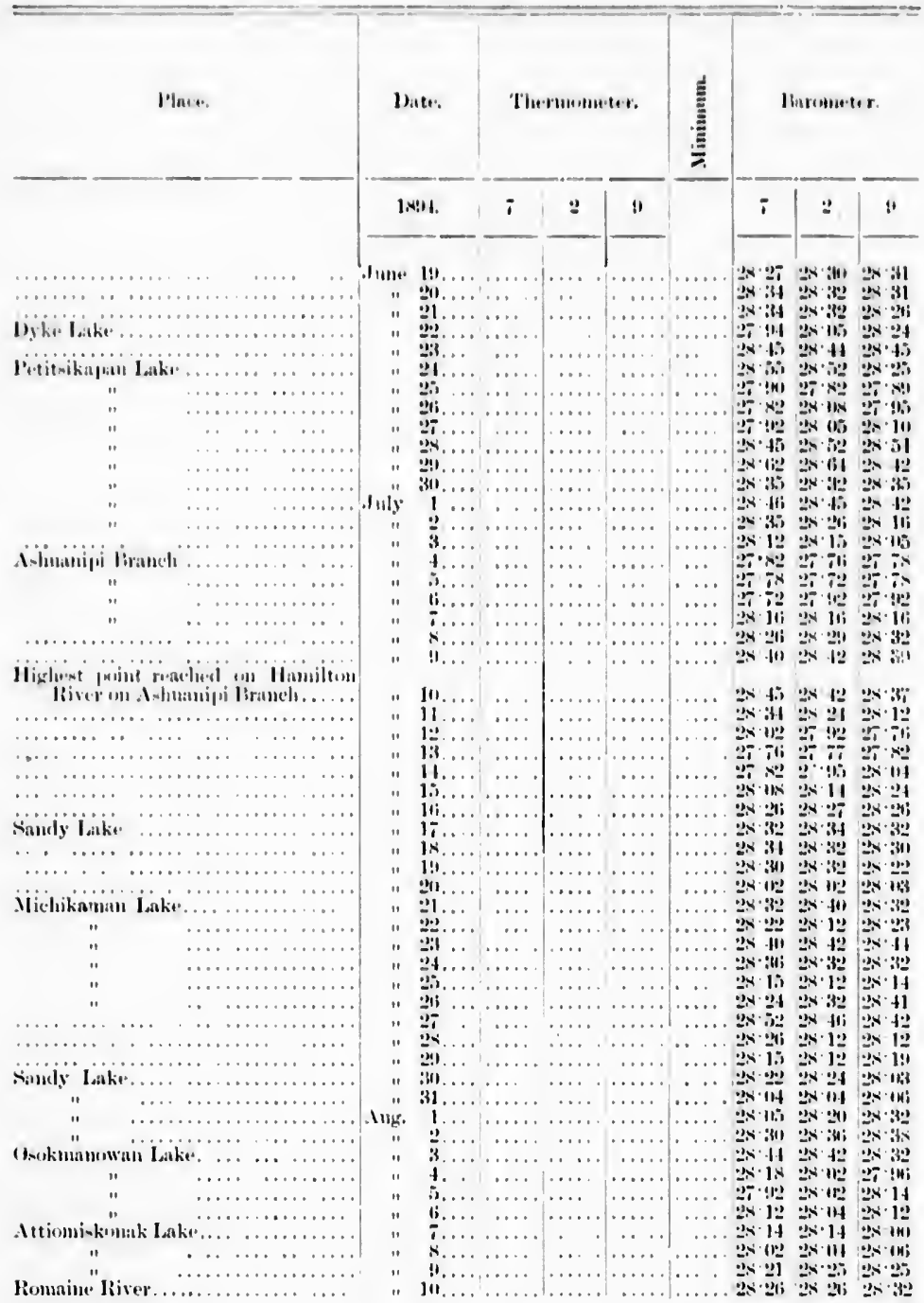


Jabralor Peninsuln, 1893.1894-Cometiuned.

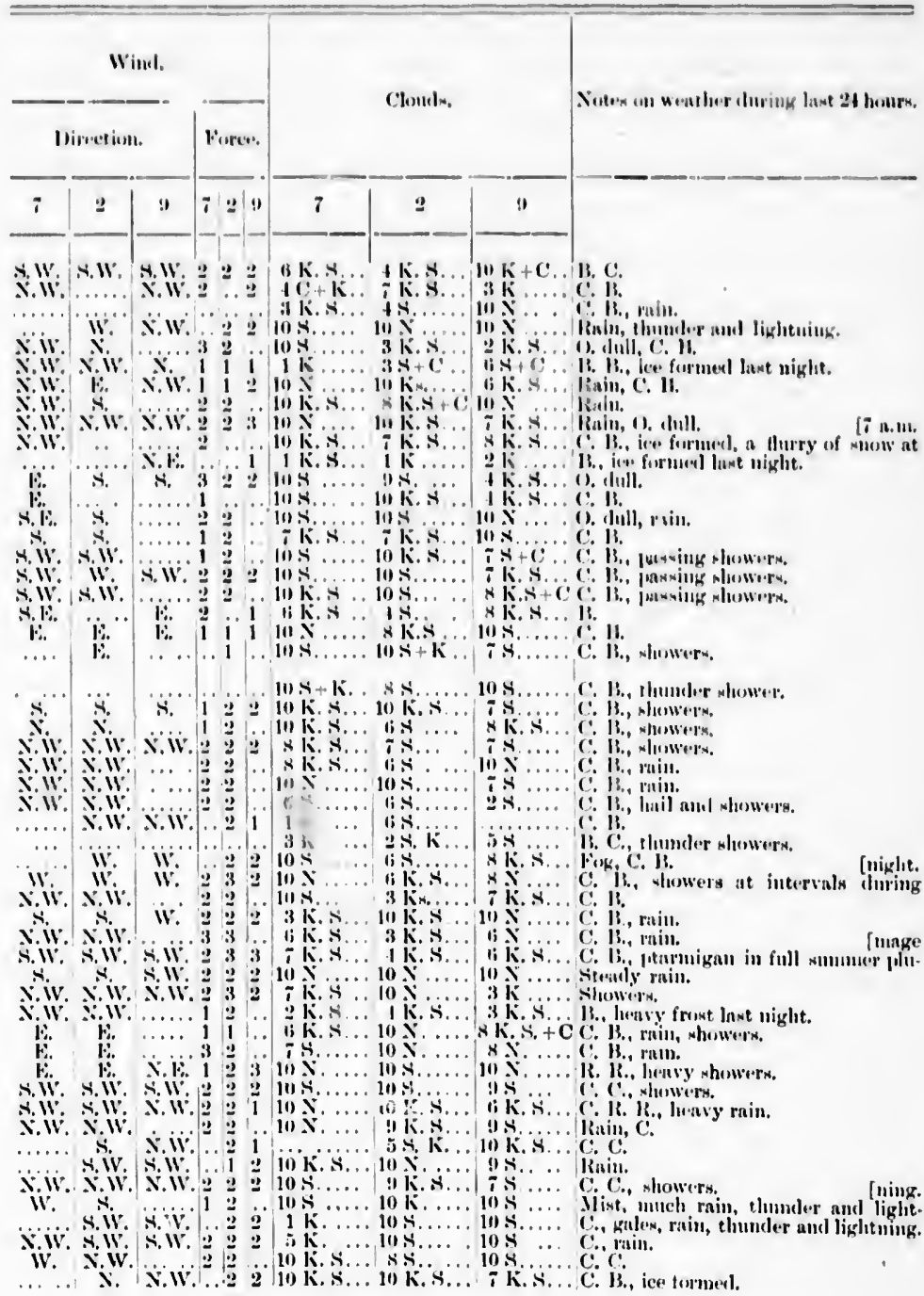


Metronological OBservations in the

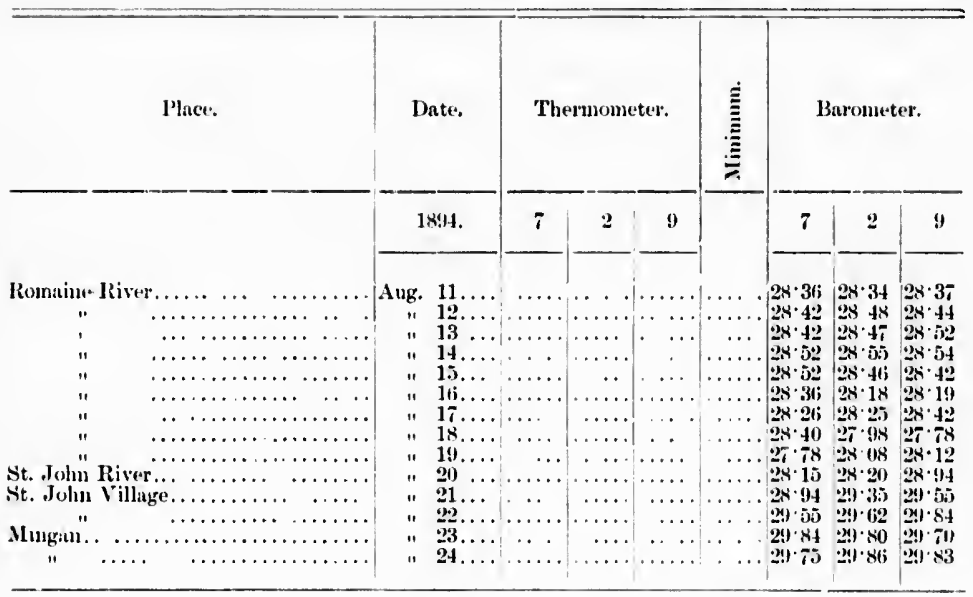


cow. J

APPENDIX VII.

383 L

Labrador Peninsula, 1893-1894-Continued.

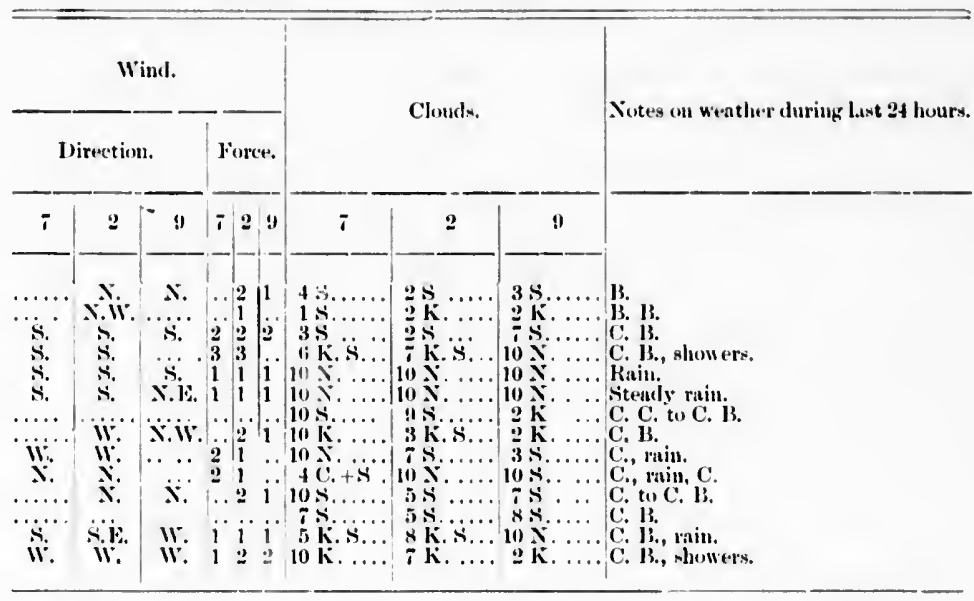


A P P E N

Meteorolorical Onsirvitugss in the

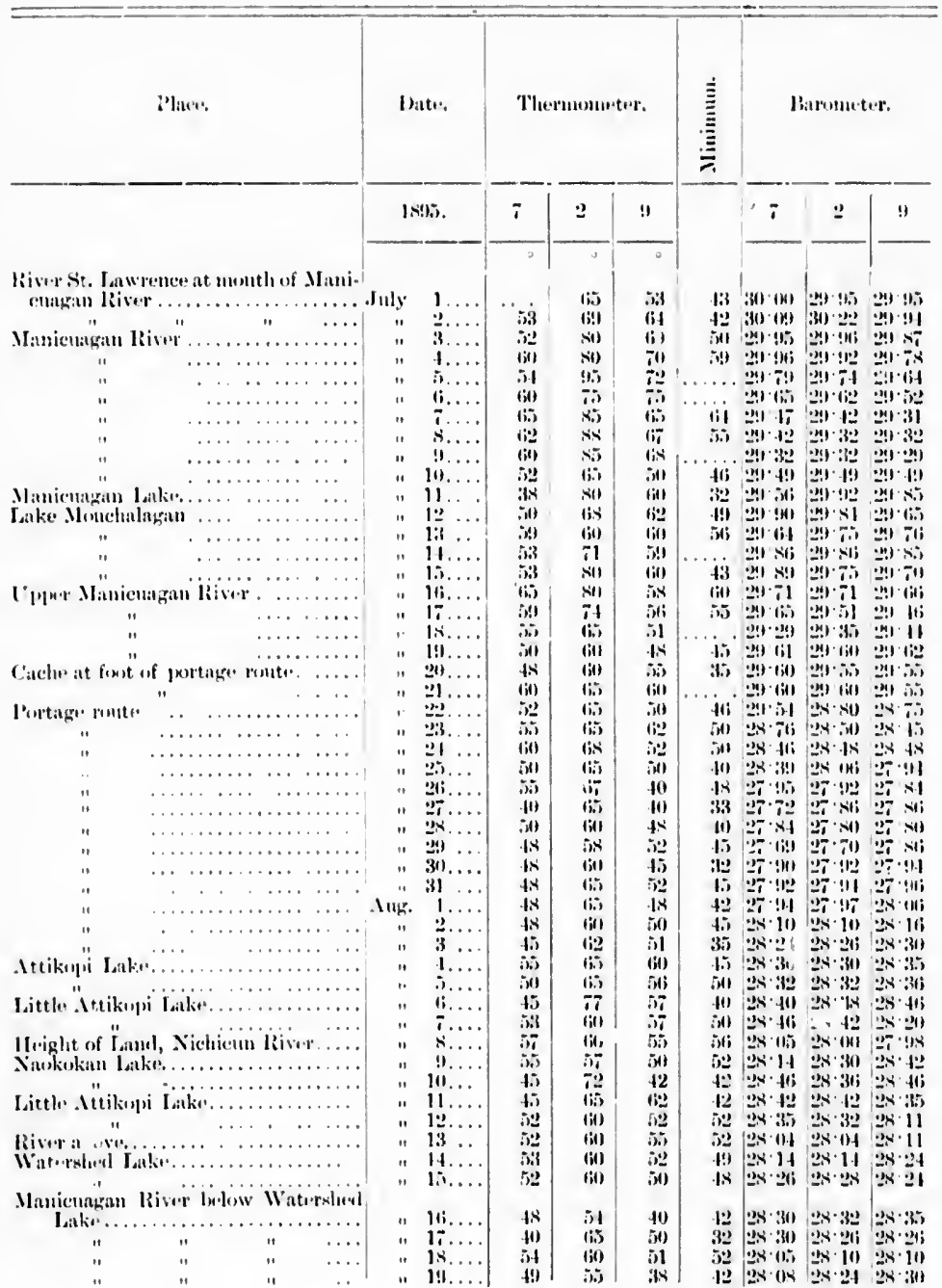


D I X VI I .

Labrador Peninsula, 1895.

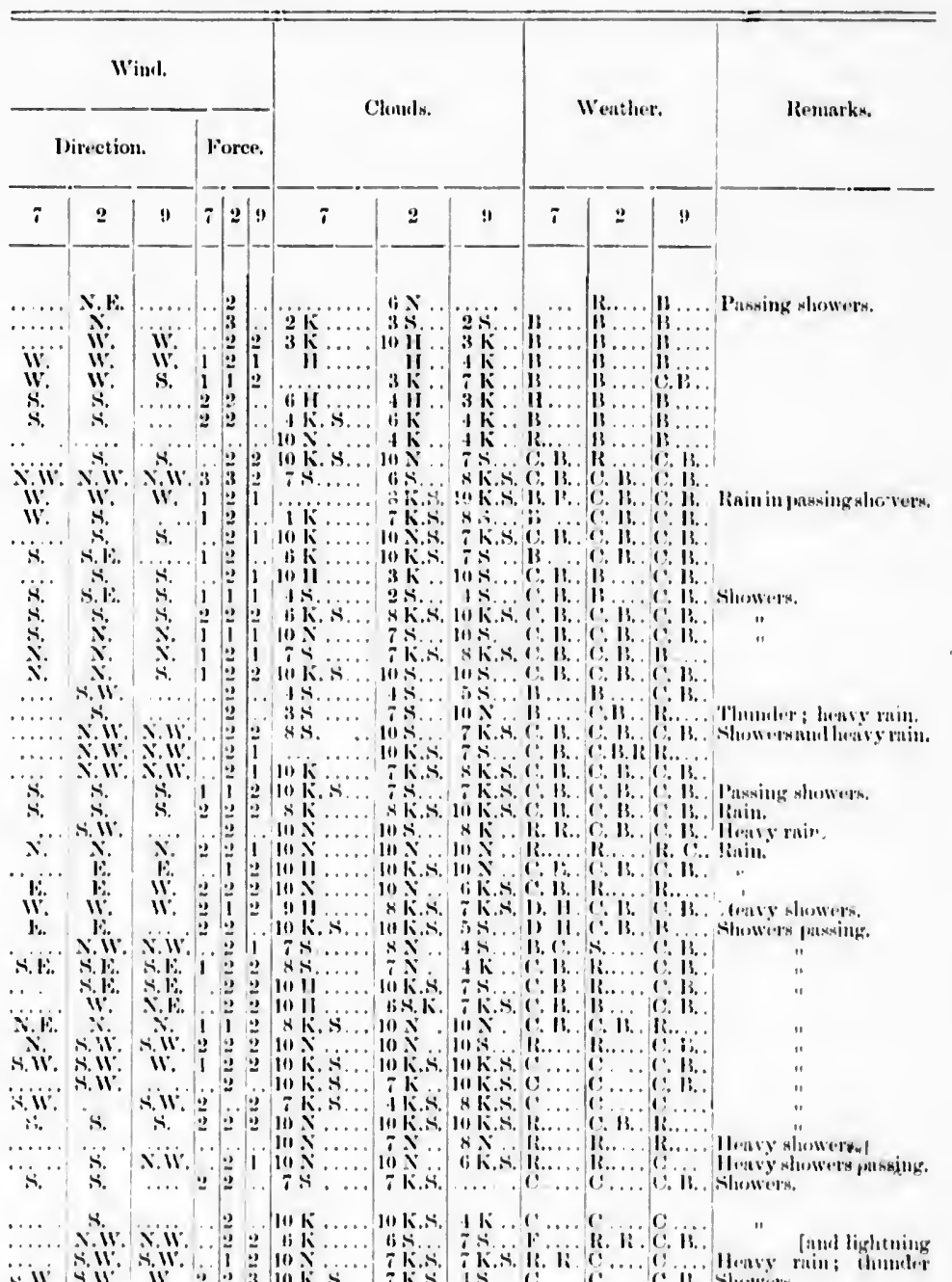

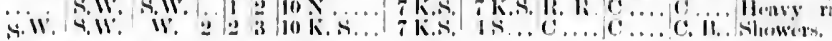


Metkololofical Onskitvations in the

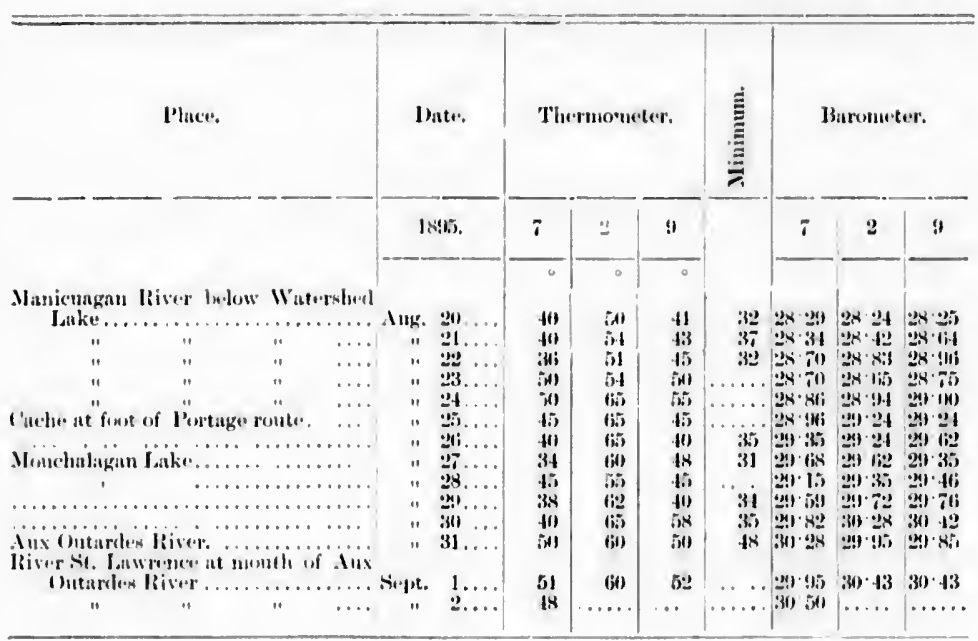


cow. $]$

APPENDIX Vil.

387 เ.

Labrulor Peninsuln, 1895-C'ontinued.

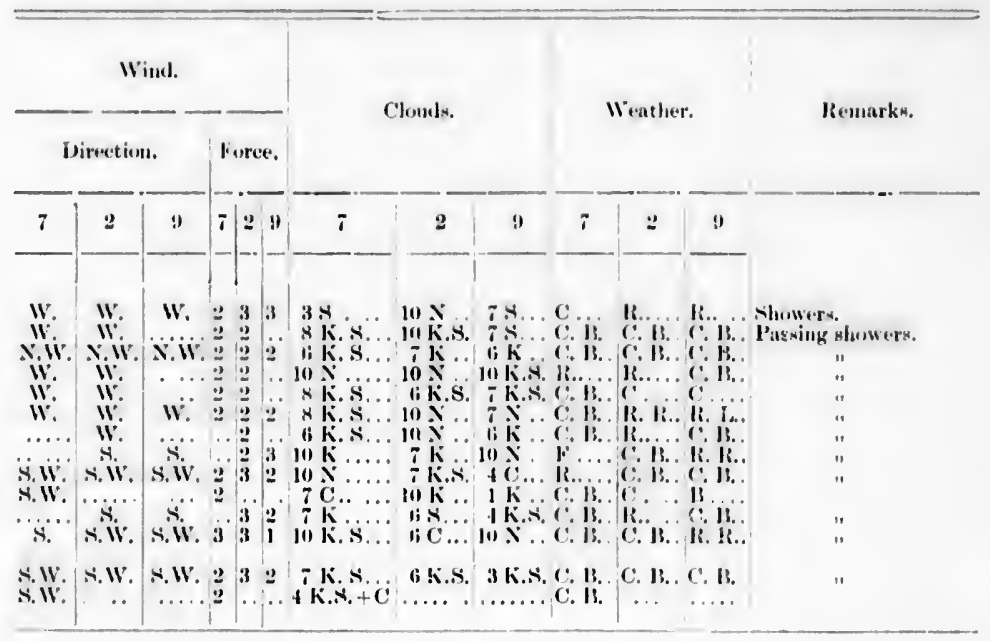




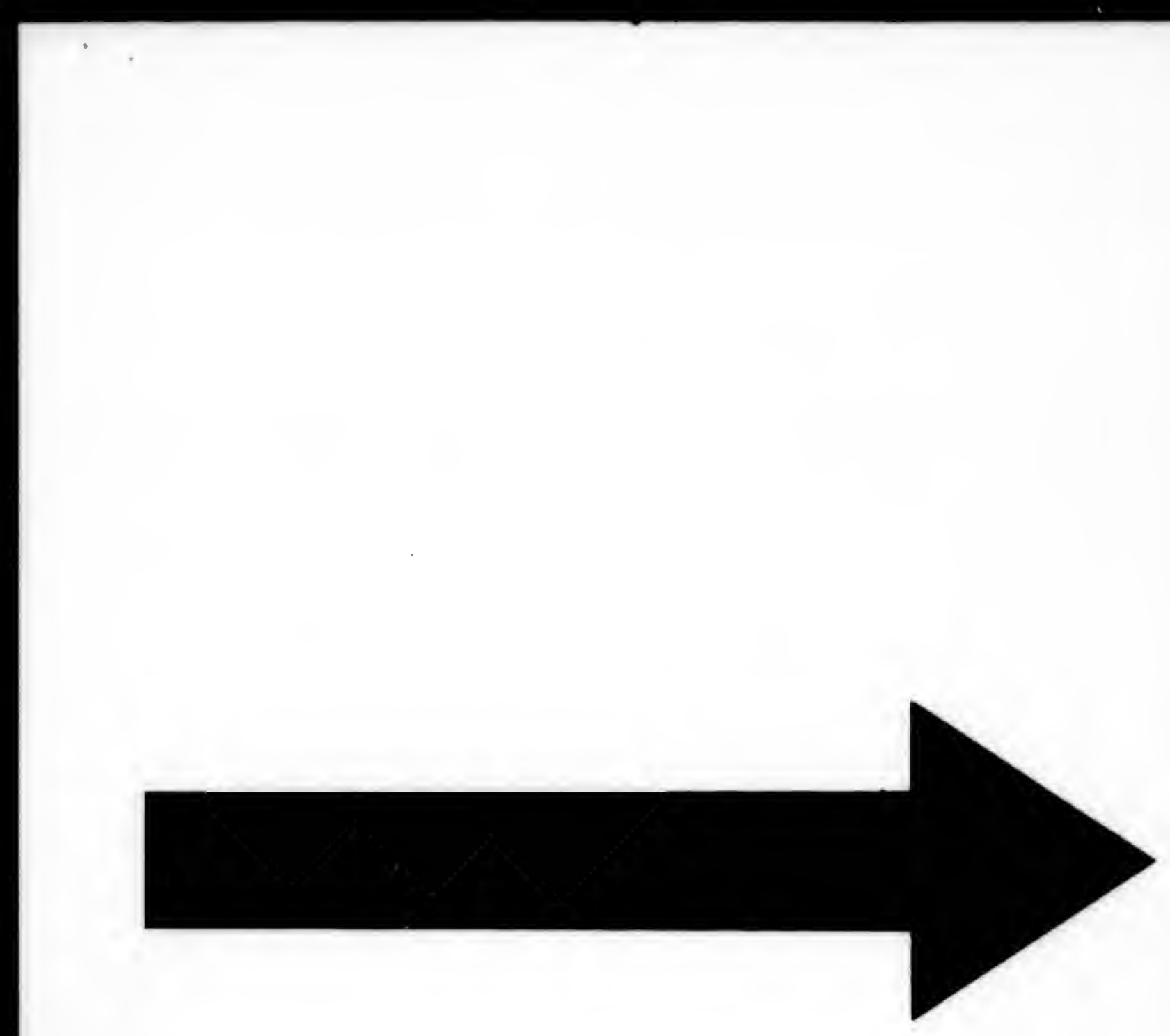




\section{IMAGE EVAIUATION TEST TARGET (MT-3)}
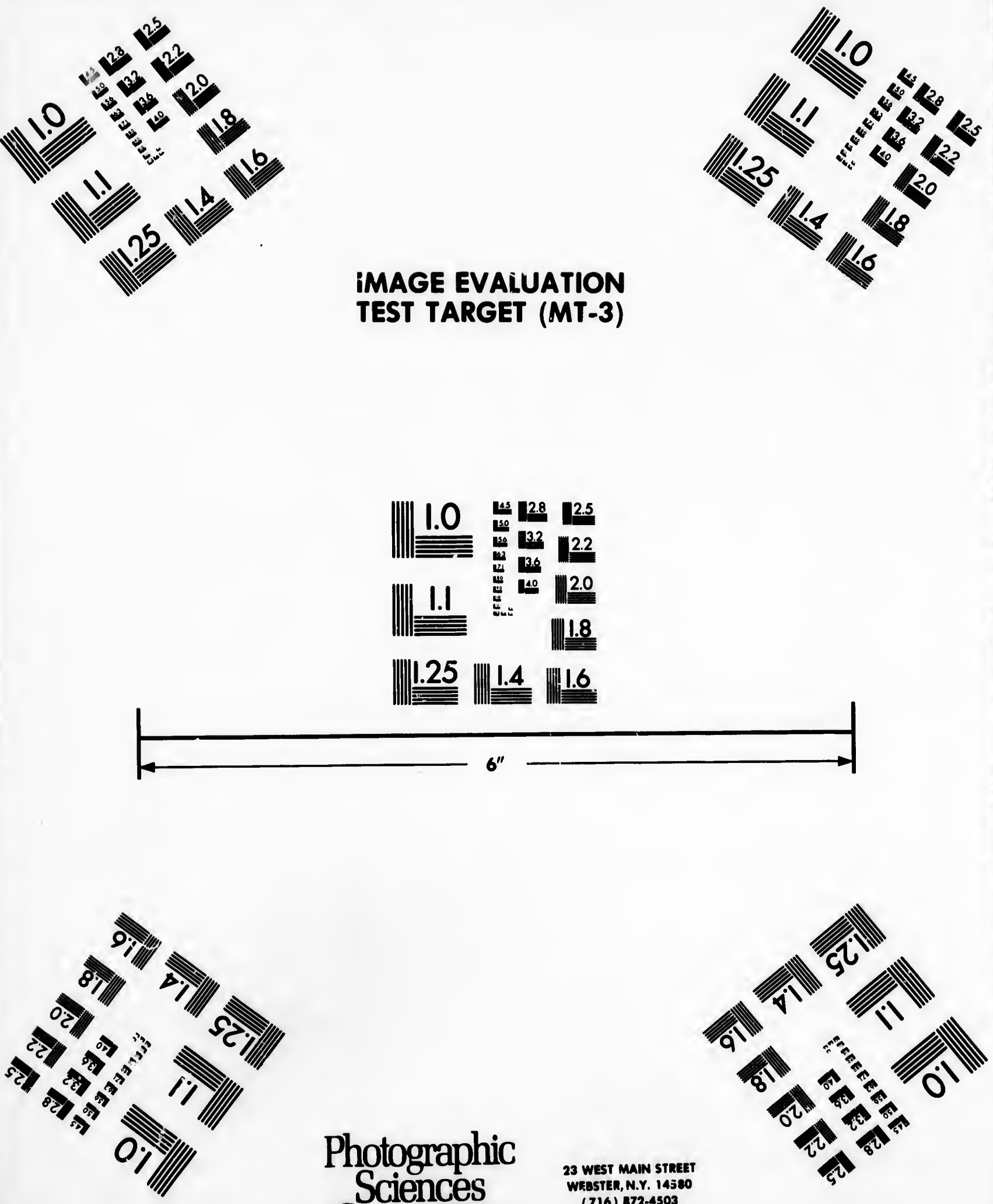

Photographic Sciences Corporation

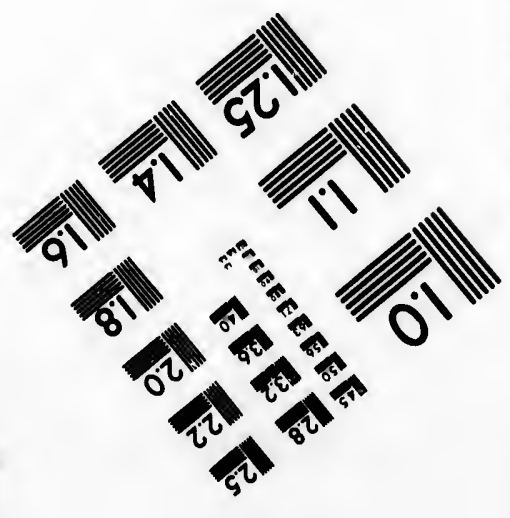




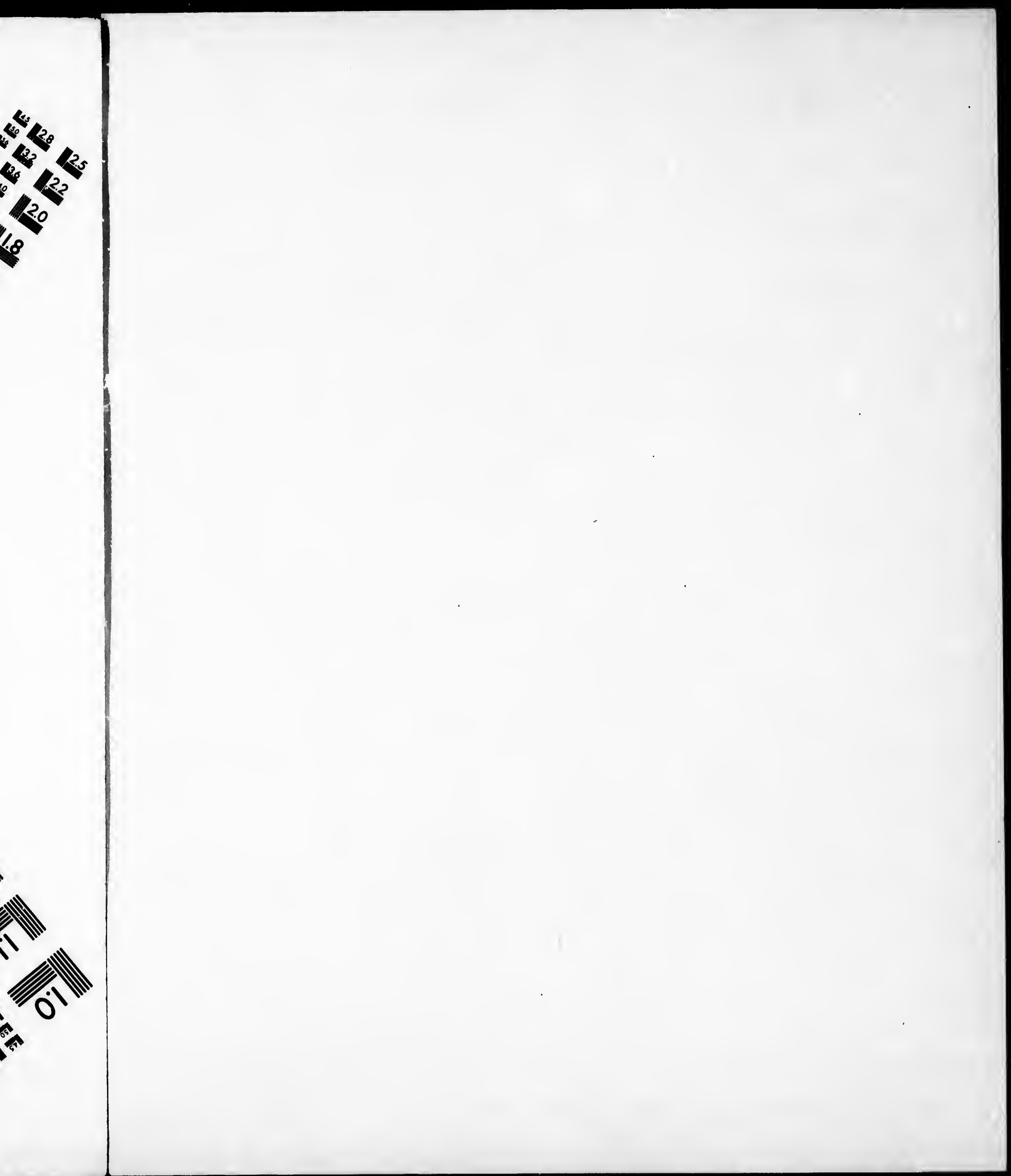


585

\section{LABRADOR PENINSULA.}

South-West Sheet. 


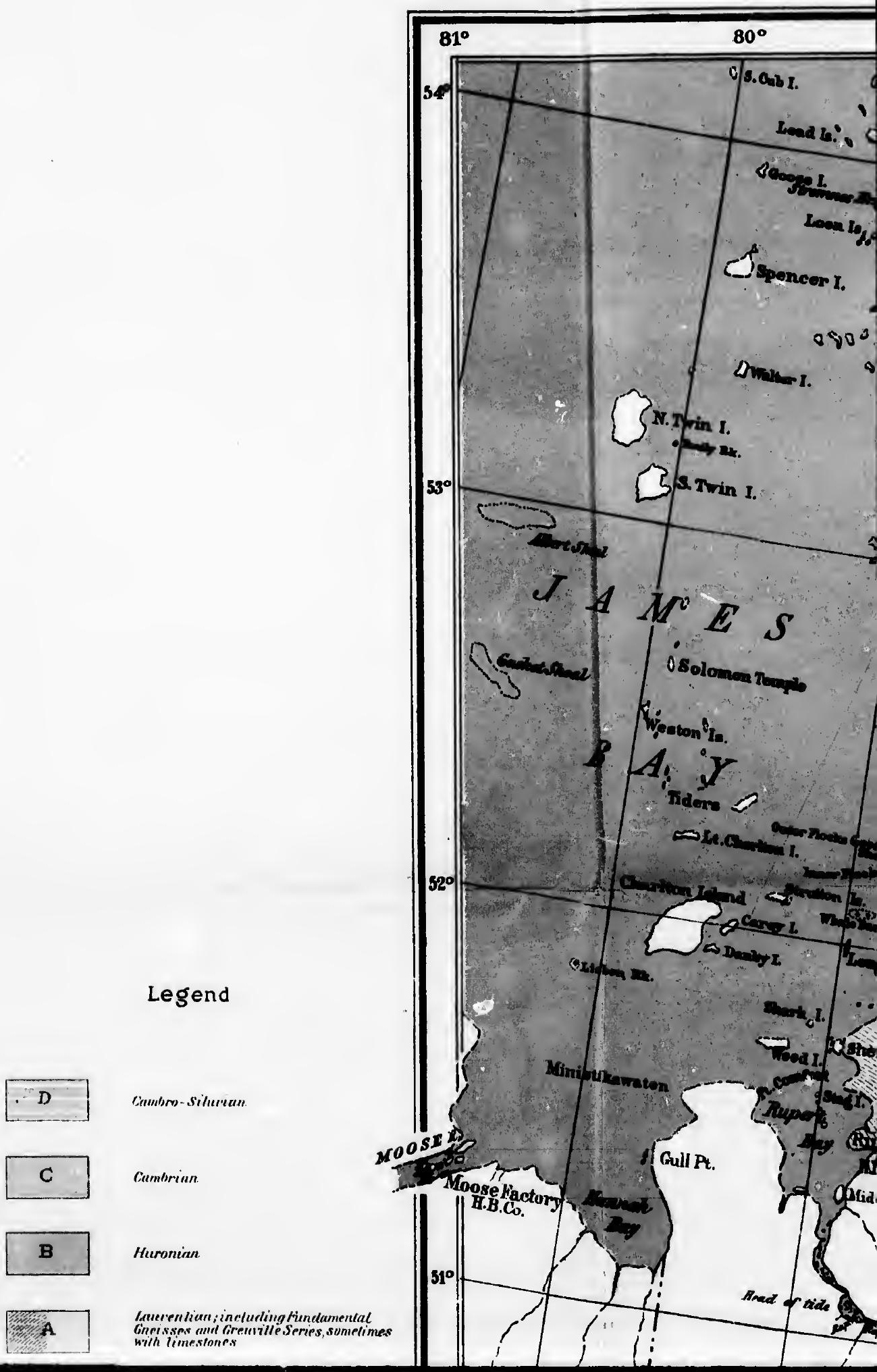




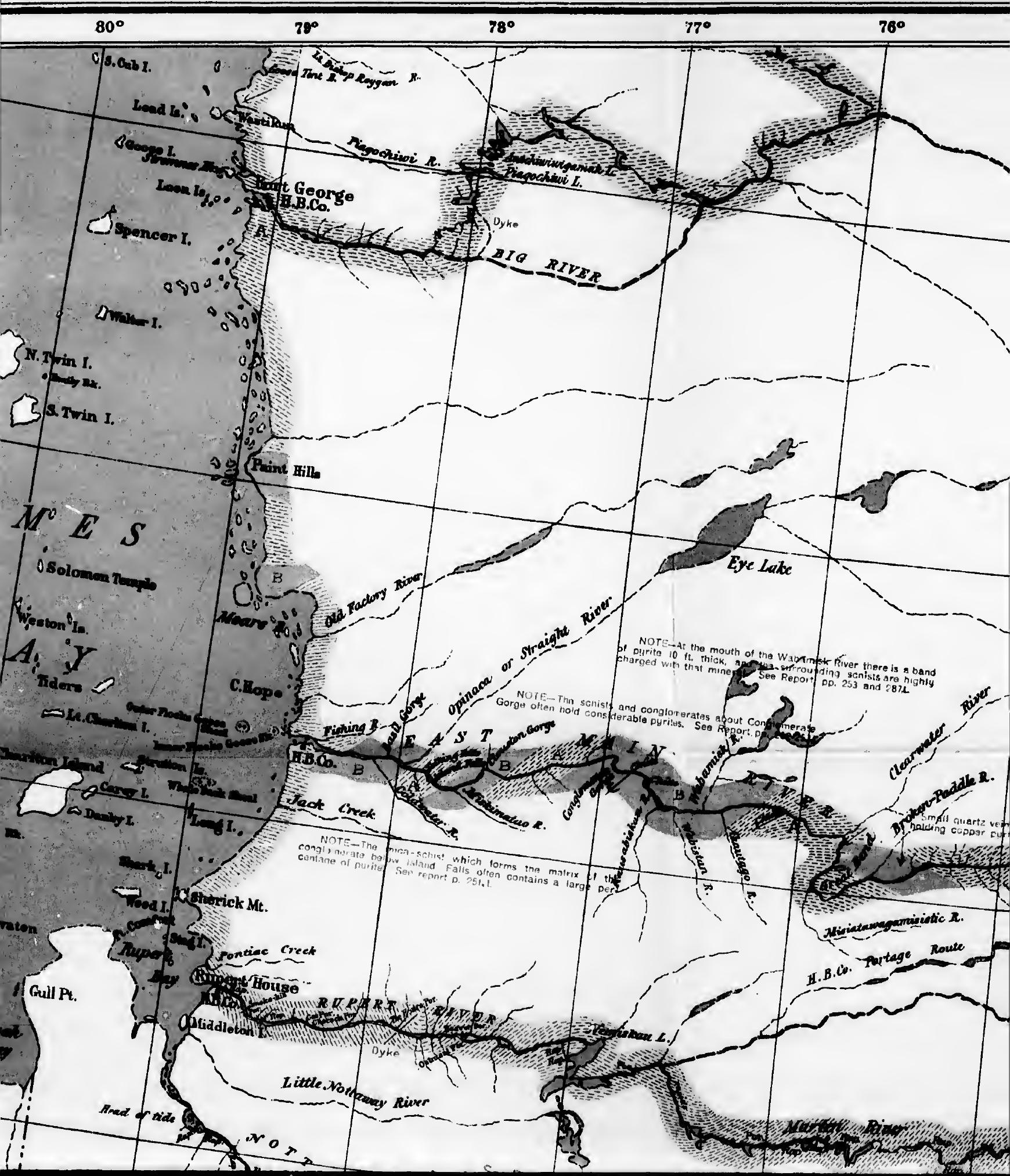


(Grulngiral Sumeng tiantada

GEORGE M.DAWSON, C.M.G.LL D,F.R.S.AC,DIRECTOR

Iagn

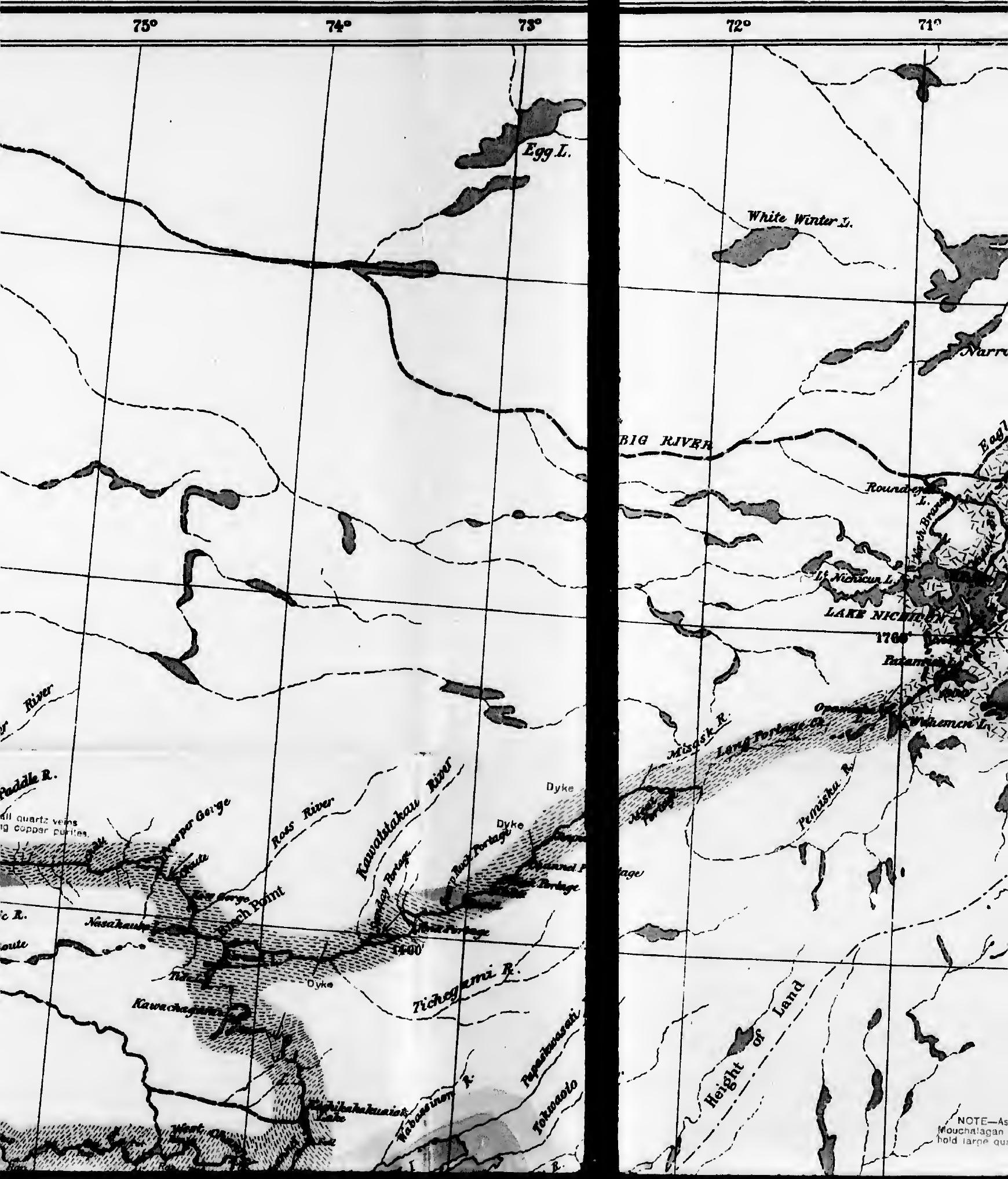




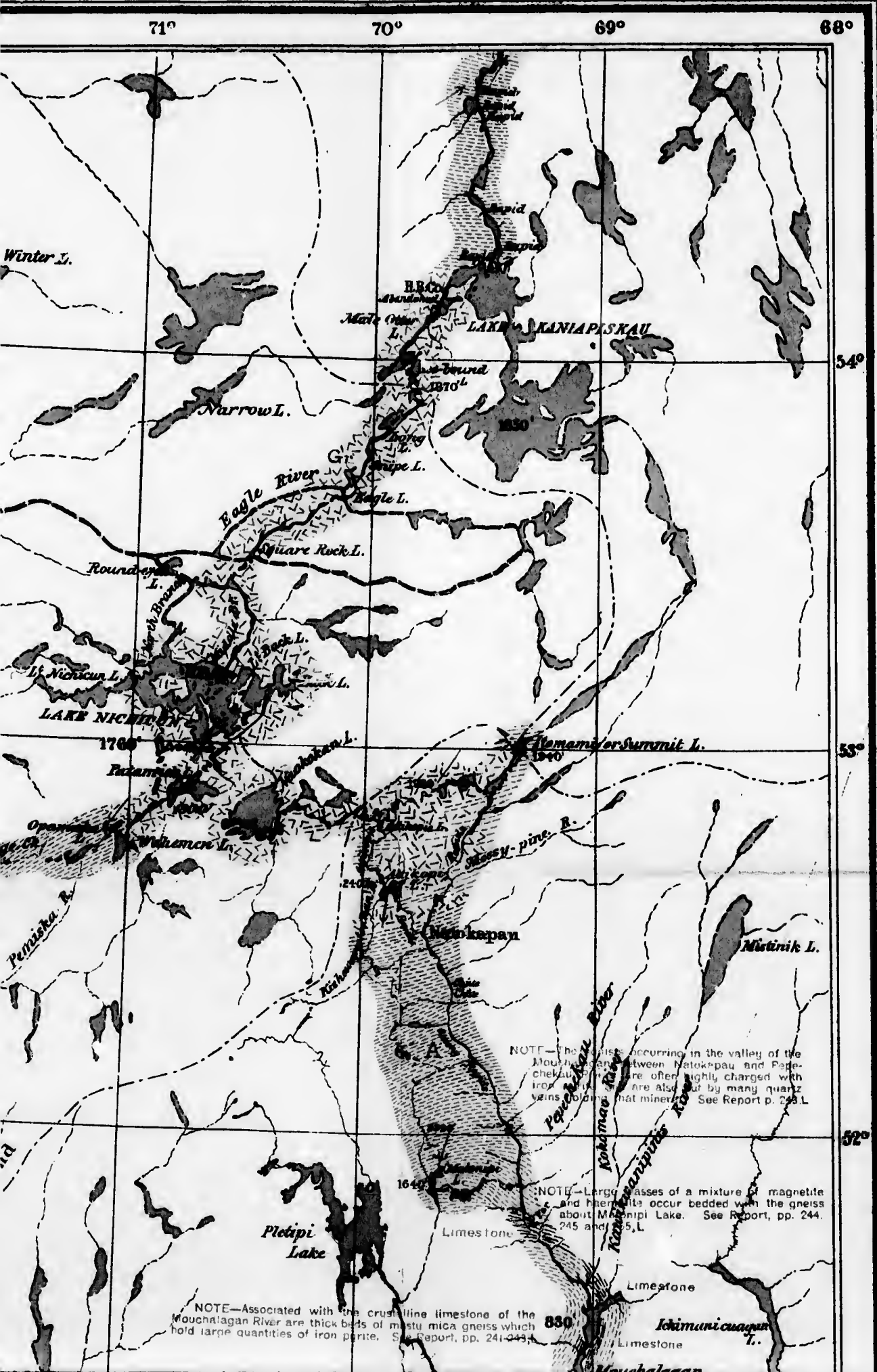


586

\section{LABRADOR PENINGULA.}

South-East Sheet. 


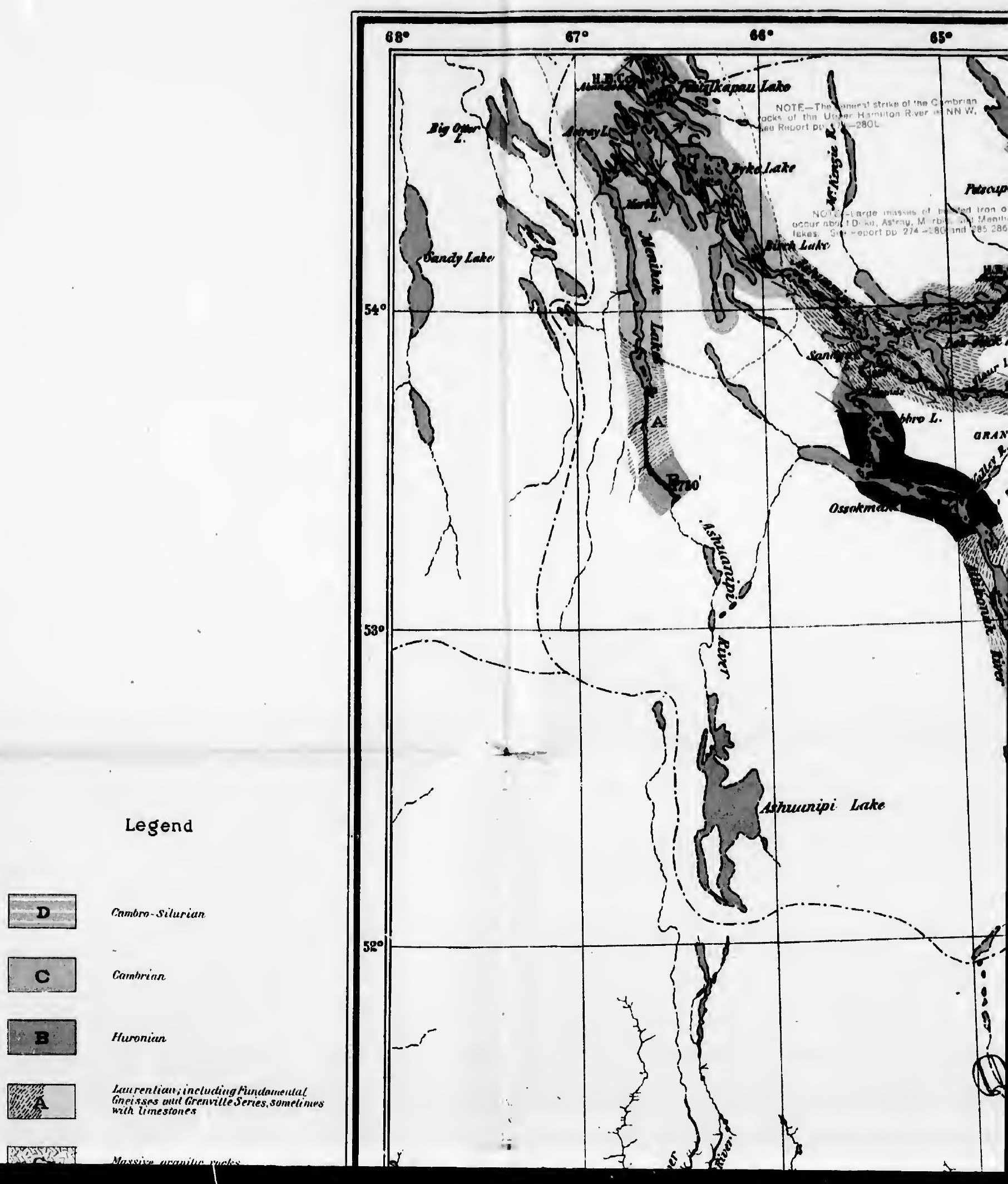




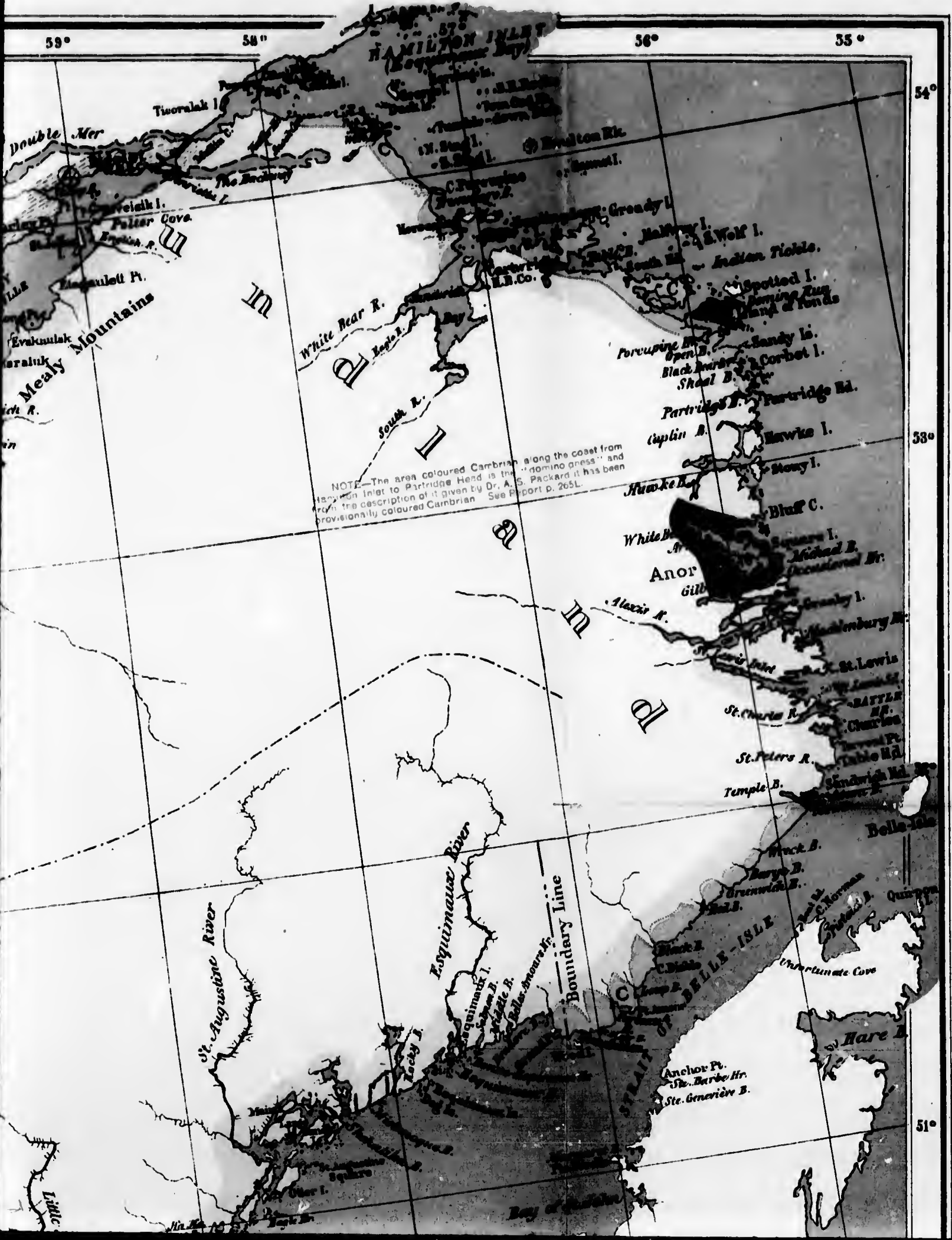




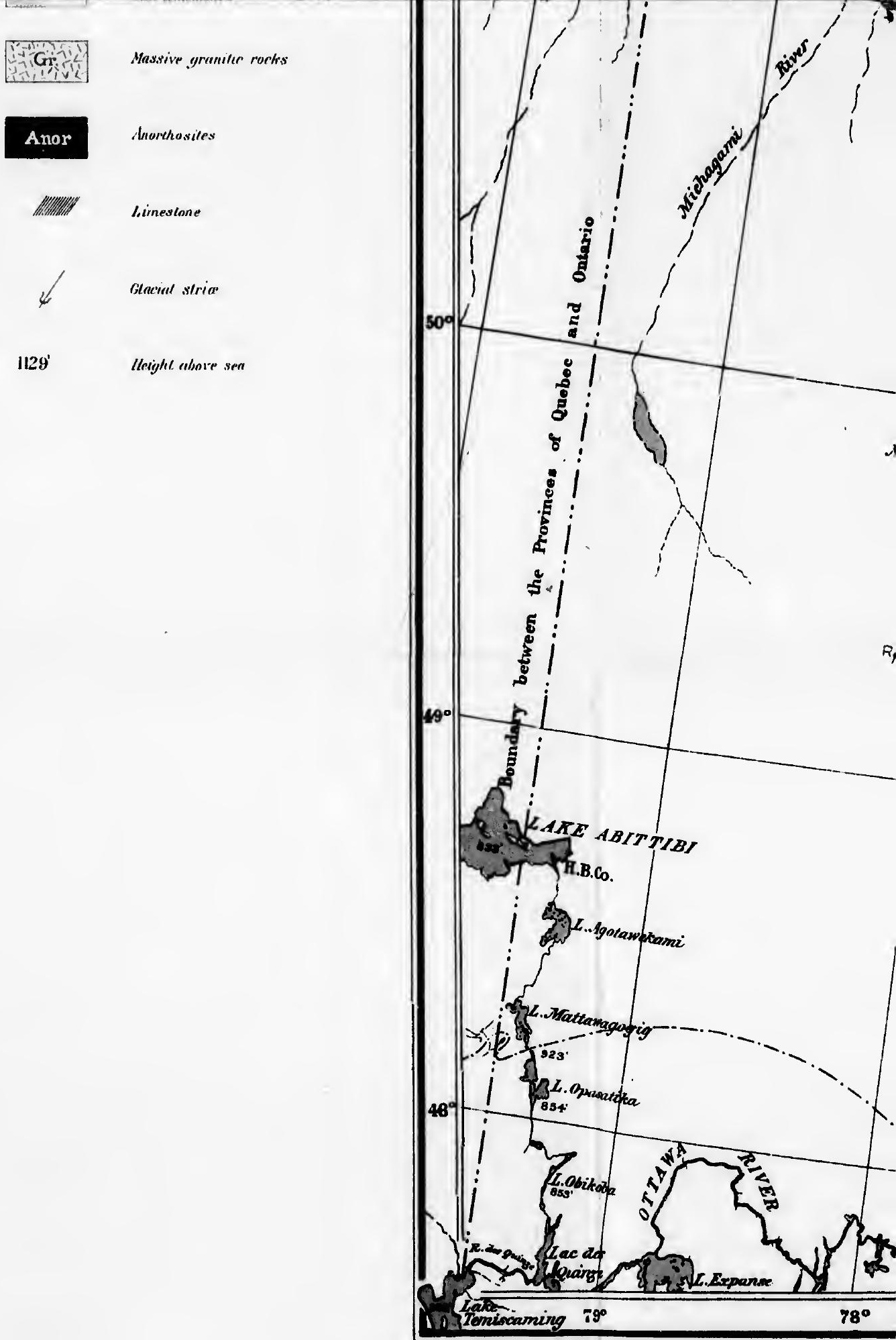

Compiled by D. I. VE Earon, C.E.

Drum for photo-lithography by G. O.Senecal, C.E: 


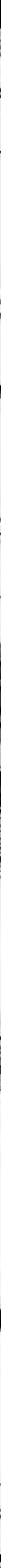

$\because E:$

y by C.O. Senécal, C.E:
SOURCES OF INFORMATION. GEOGRAPMICAL.

Const line frun various Admiralty Charts excepting :

(1) East coast of Hudson Bay between Portland Promontory and Great Whale River, from map by Dr. R. Bell, $1877 \cdot 78$.

(a) Coast and islands of James Bay from charts of Capts. Taylor and Bishop, of the H. B. Co's vessels, with corrections by A. P. I low, 188,

Rivers of the southern watershed chiefly from surveys of the Department of Crown Lands, Quebec. Nottaway River from survey by R. Bell, 1895, Rupert, East Main, Koksoak, Hamilton, Romaine and portions of the Big, Great Whale, Clearwater, Manicuagan and North-west rivers, from surveys by A. P. Low and D. I. V. Enton. Rivers and lakes shown in dotted lines are from sketch-mops of H. B. Co. The central interior from a map made by John Spencer and John Beads at Nichicun (1842). The routes between the East Main and Nottaway rivers from a map complled by Jas. Clouston (1824) 


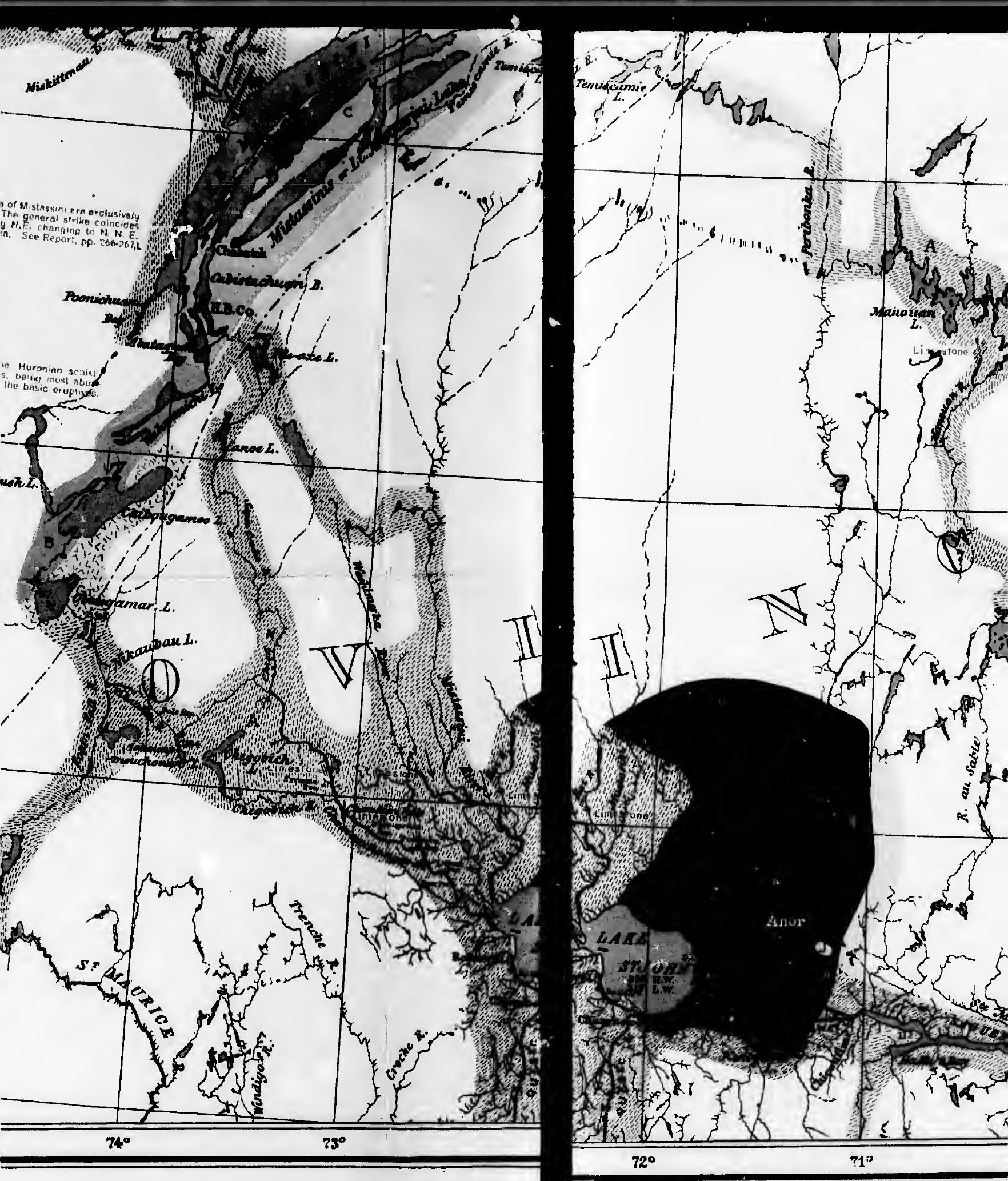

South. West Sheet

MAAP

-- of -

LABRADOR PENINSULA

Netural Seale: Intow

Sicule: 25 milas wo ome inch
The geolos

(1) $\mathrm{Fal}$

(p. זi, I...).

(3) $\mathrm{Ob}$

\section{SOURCES OF INFORMATION.}

Geolocical.

The geological Indications include:

(1) Facts oblained during A, P. Low's expeditions of $3892,193,94, ' 95$ and ' 96 .

(2) Observations contained in previous reports of the Geological Survey as enume

(p. s. L.). including work by J. Kichardson, W. McOuat, R. Bell and F. D. Adams.

(3) Observations of A.S Packard on the'coast between Belle Isle and Nain. 


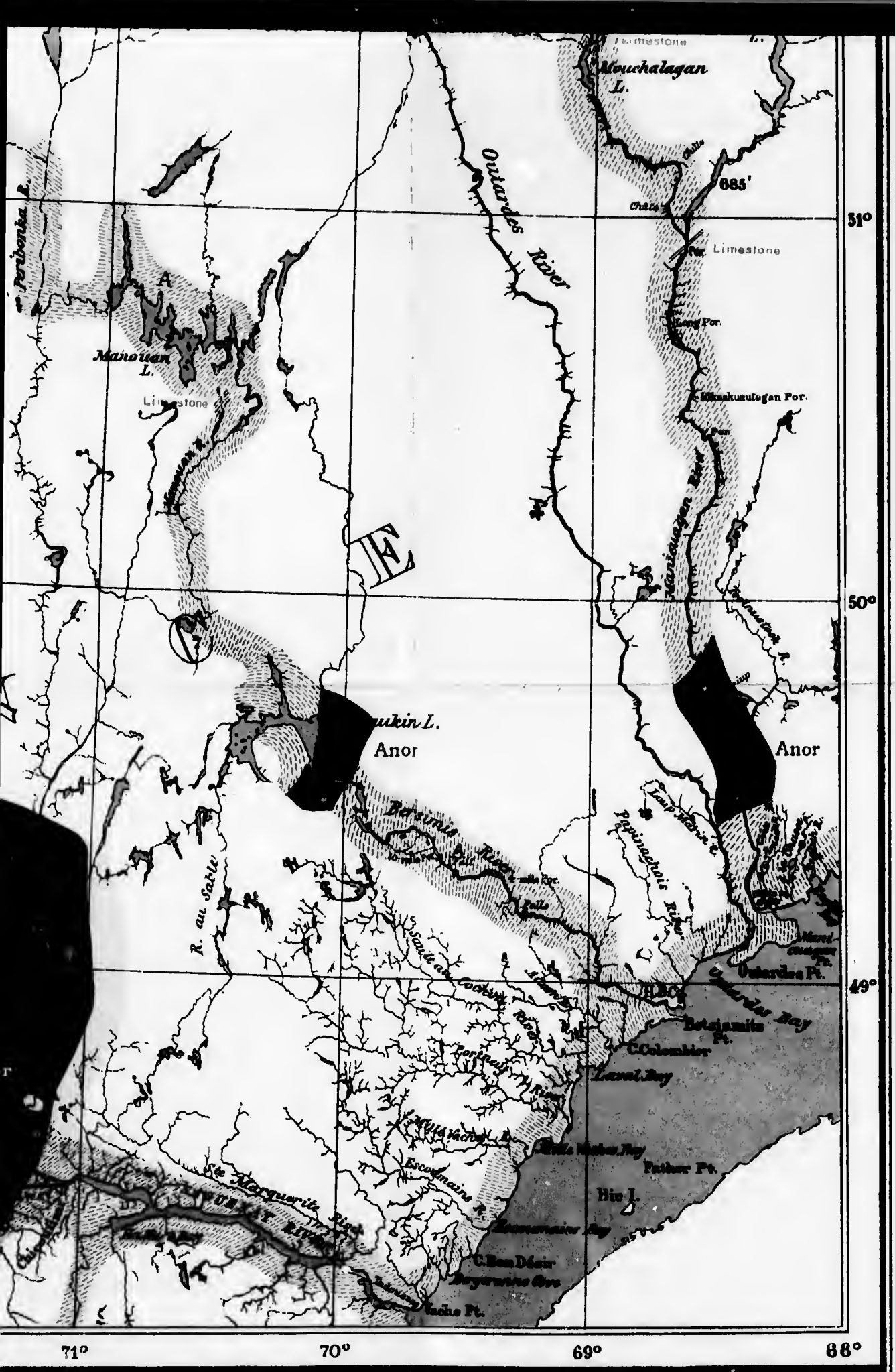

Acrompanying Heport by. A. I.Low, B.Ap.Sc, Part L, Voi.VIII,(NewSeries) RCES OF INFORMATION. Geological.

reditions of 1892 , '93, '94, '95 and ' 66 .

ports of the Geological Survey as enumerated in the accompanyiog report

w. McOuat, R. Bel] aod F. D. Adams.

coast between Belle Isle and Nain. 


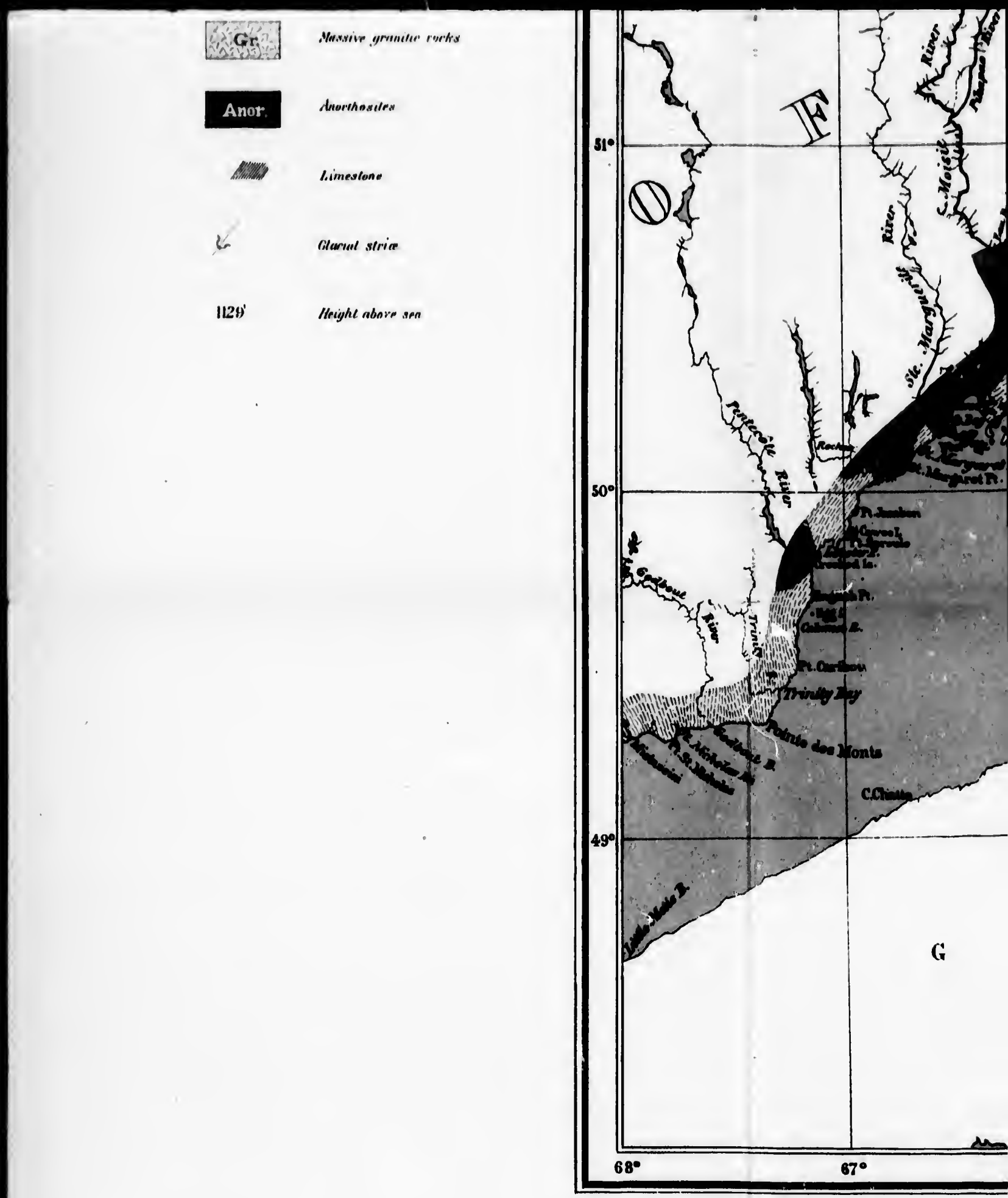

Compiled by D I.V. Entom. C.E.

Draun for photo-lithography by C: O. Seneral C:L: 


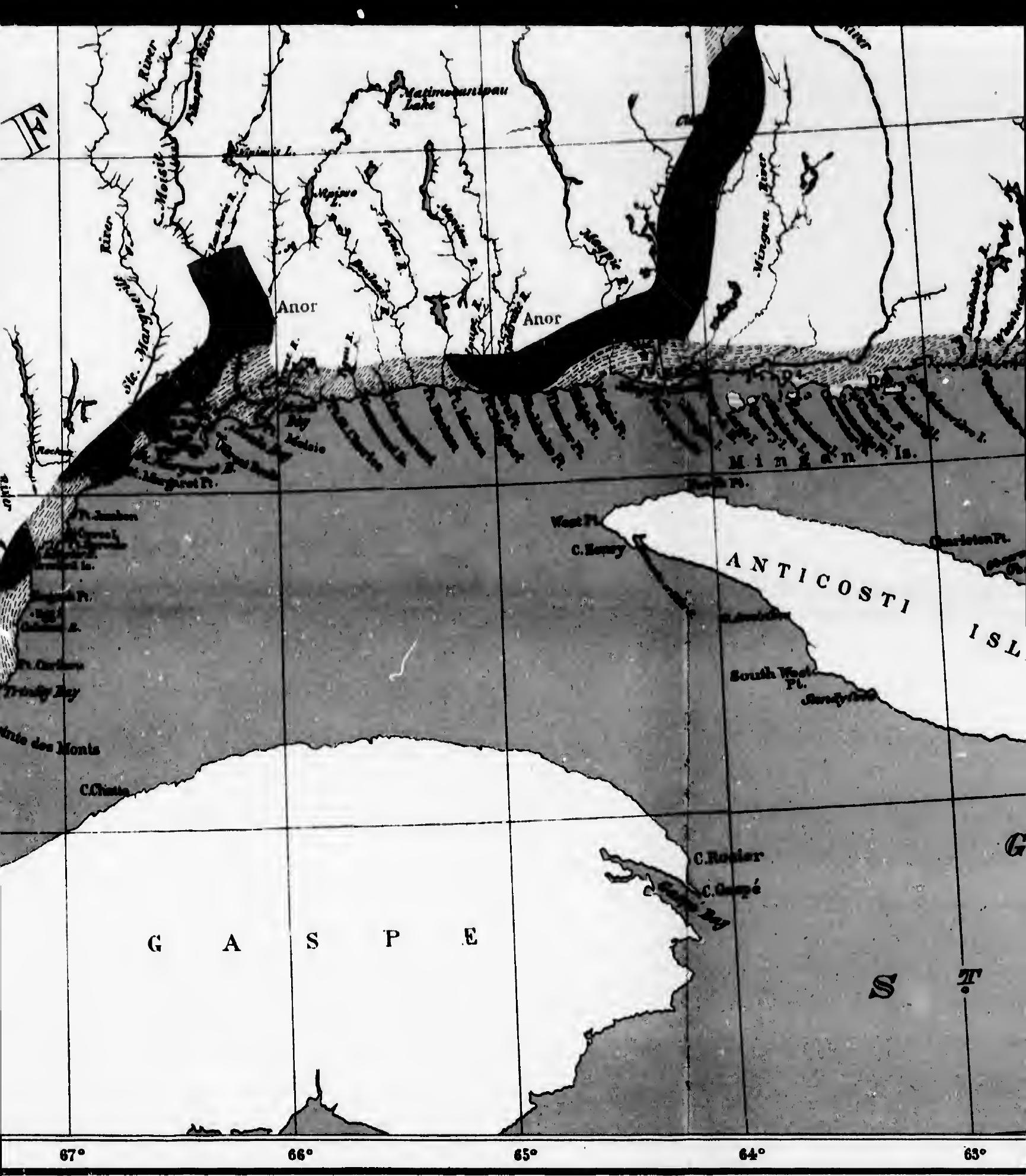

Const line from various Admiralty Charts excepting :

(r) East coast of Hudson Bay between Portland Promontory and Great Whale River, from map by Dr. R. Bell, $\times 877 \cdot 78$.

(2) Coast and islands of James Bay from cherts of Capts. Taylor and Bishop, of the H. B. Co's vessels, with corrections by A. P. Low, $x 887$.

Rivers of the southern watershed chiefly from surveys of the Department of Crown Lands, Quebe:. Nottaway River from survey hy R. Bell, 1895, Rupert, East Maiu, Koksosk, Hamilton, Romaine and portions of the Big, Great Whale, Clearwater, Manicuagan and North-west rivers, from surveys by A. P. Low and D. 1. V. Eaton. Rivers and lakes shown in dotted lines are from sketch-msps of H. B. Co. The central interior from a map made by John Spencer and John Beads at Nichicun (1842). The routes between the East Main and Nottaway rivers from $n$ map compiled by Jas. Clouston (1824) 

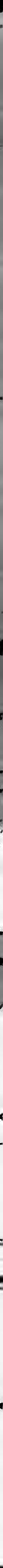

\section{.}

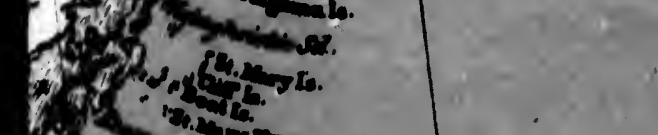

\section{.}




\section{7 \\ LABRADOR PENINSULA. \\ North-West Sheet.}




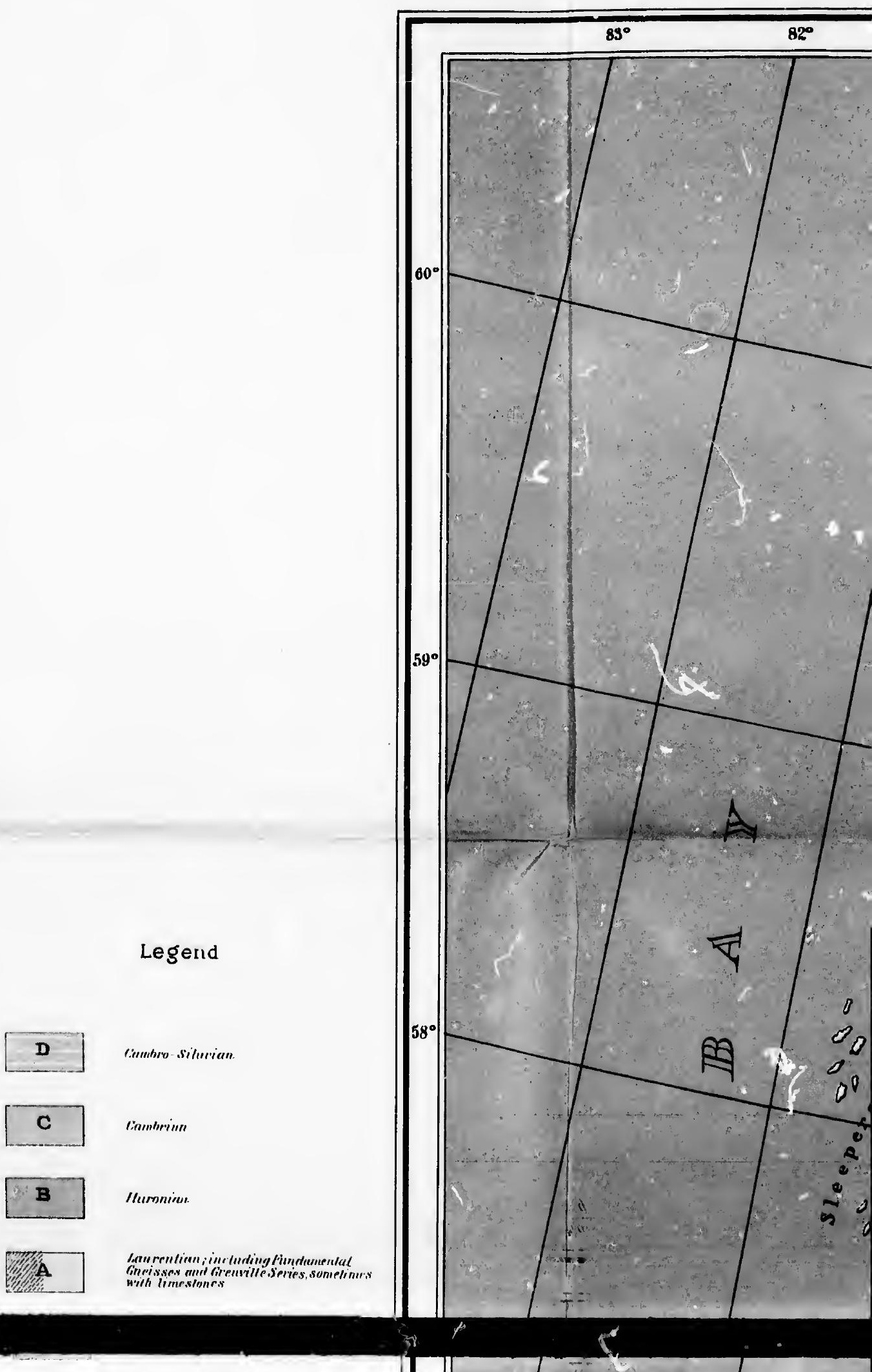


()$_{1}$

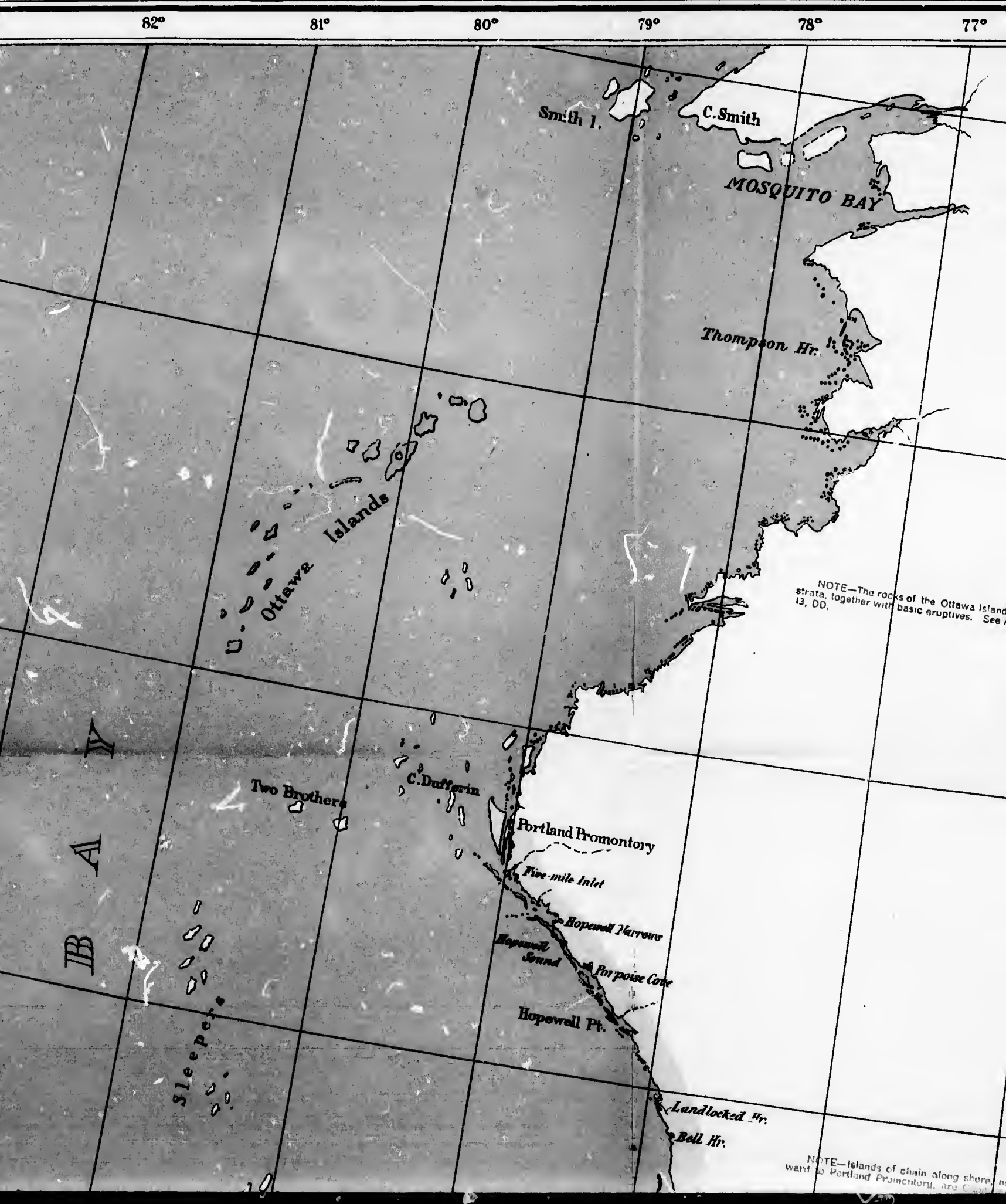


(Frnutuiral Summ of Crantada

GEORGE M.DAWSON, C.MG,LL D,F.R S AC,OIRECTOR

เด96

\begin{tabular}{llll}
$77^{\circ}$ & $76^{\circ}$ & $75^{\circ}$ & $74^{\circ}$ \\
\hline
\end{tabular}

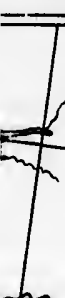

Po

uptives. See Annuai Redort Cambrian

See Annual Report 1885 ,
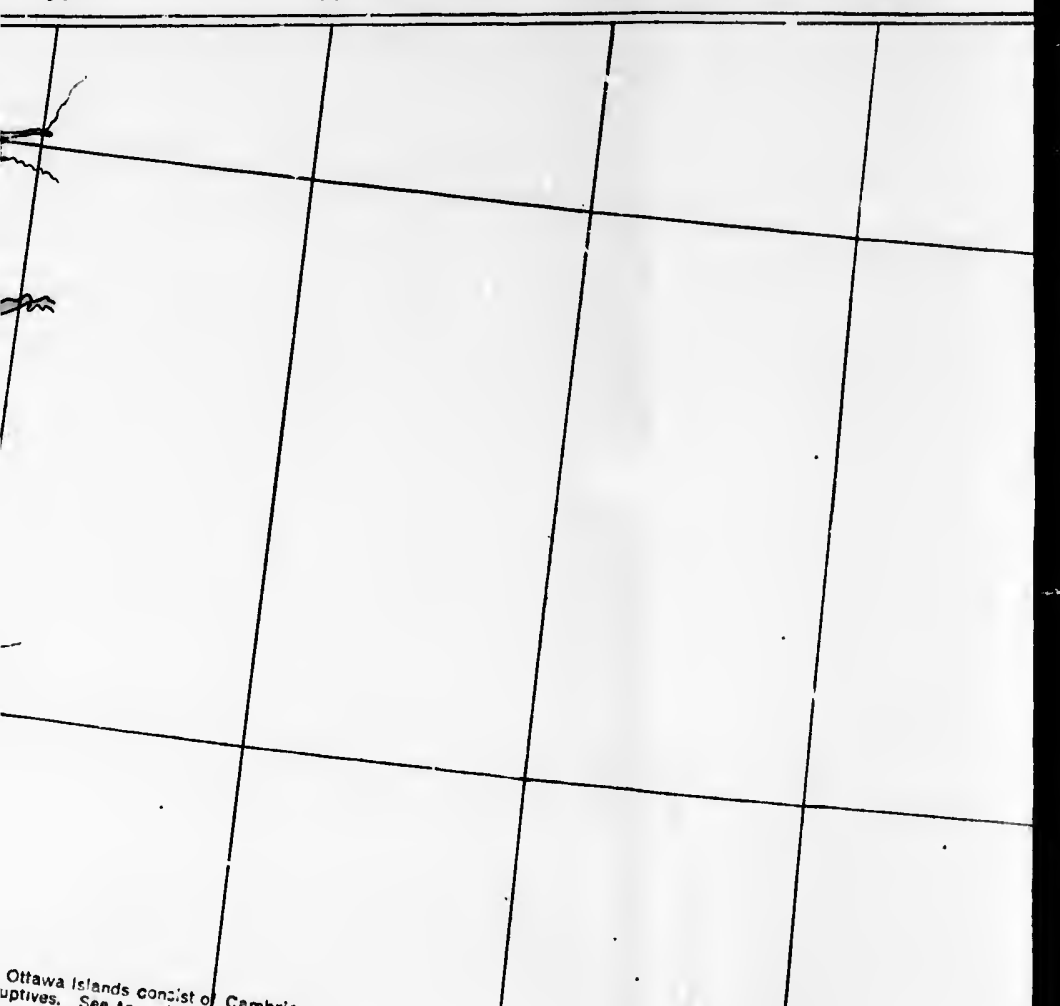


$$
588
$$

LABRADOR PENINSULA.

North-East Shetl 


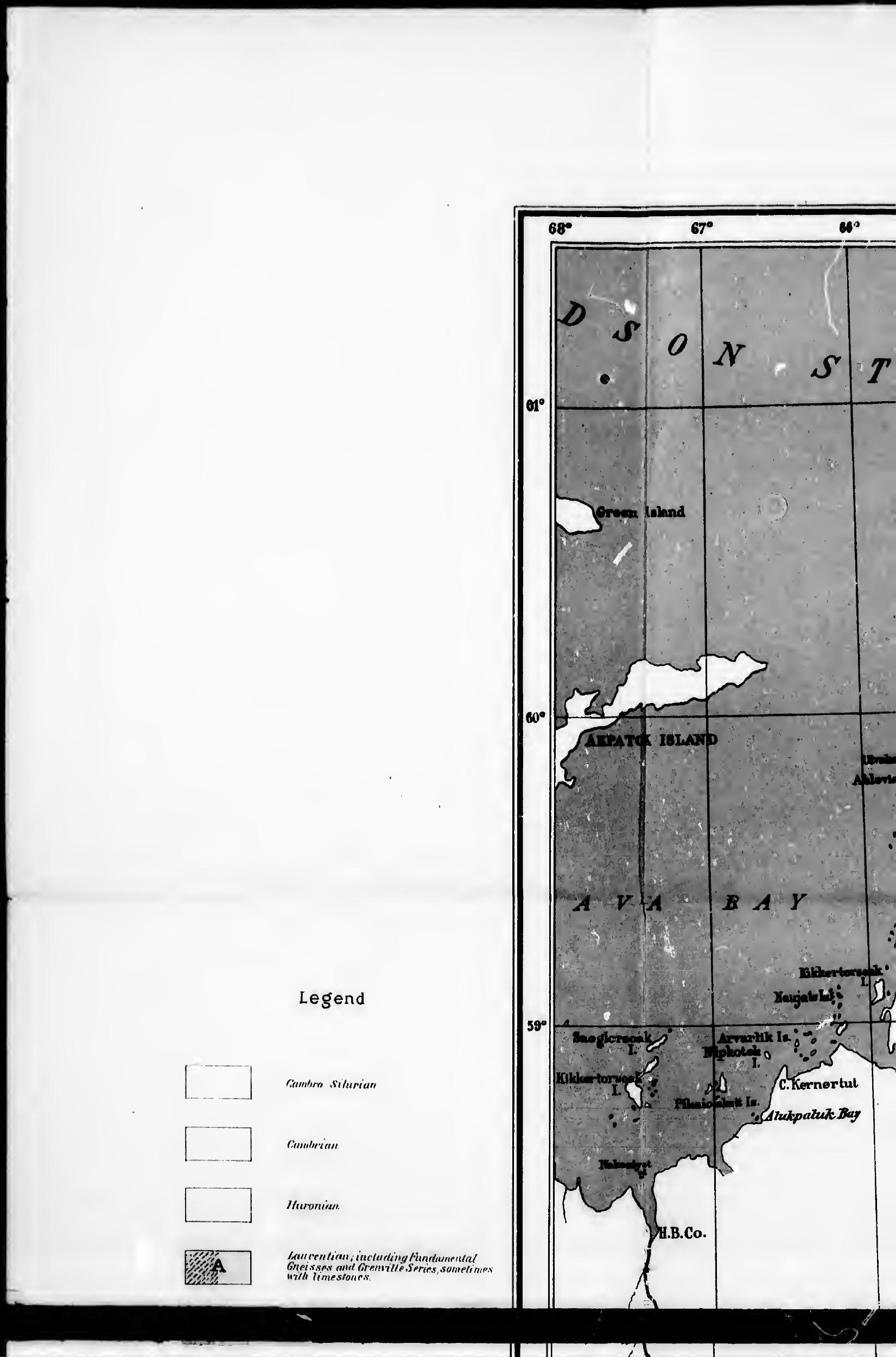




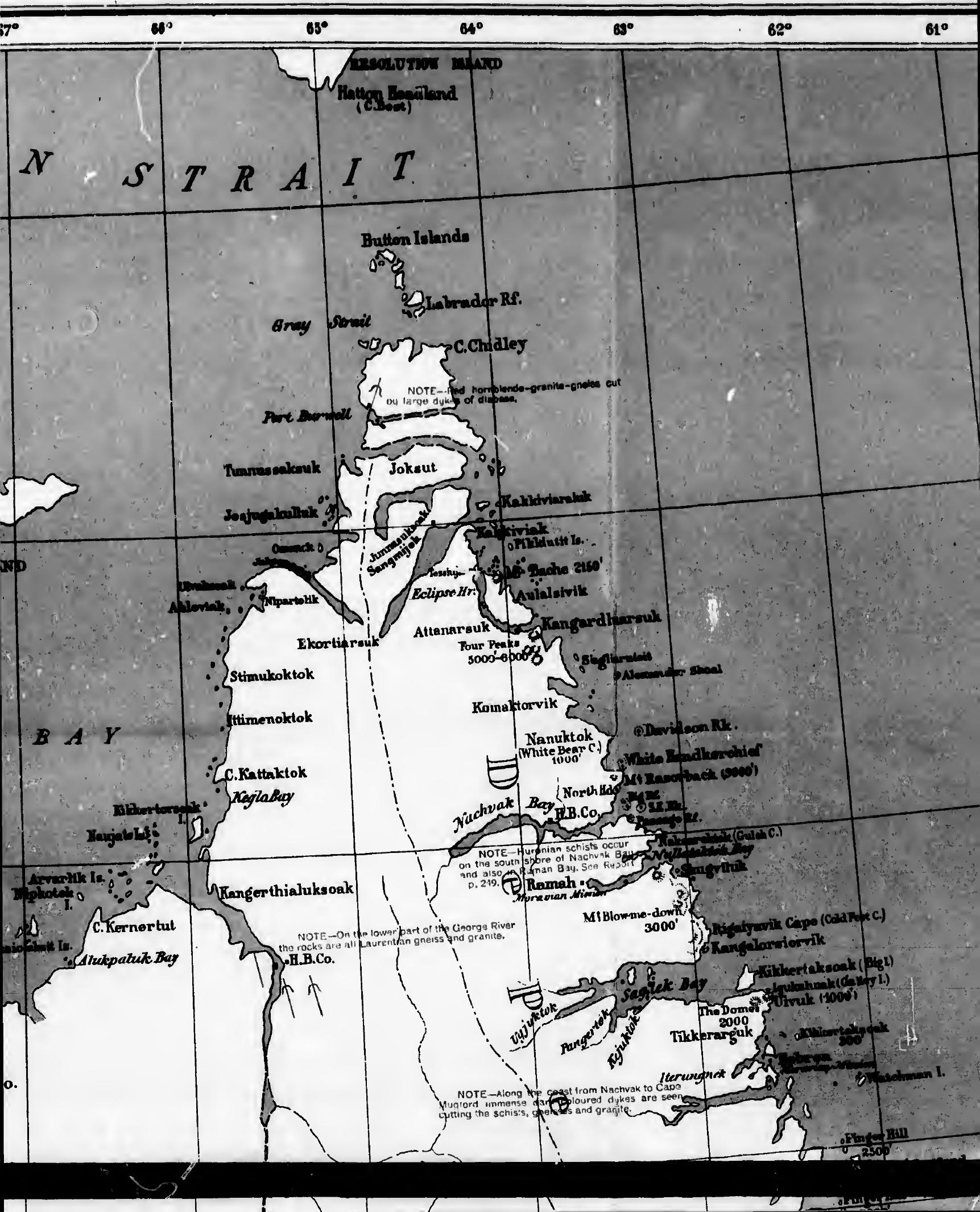




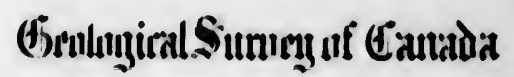

GEOAGE M OAWSON, CMO,LL D, FR S AC, DIAECTOA

Iape

$61^{\circ} \quad 60^{\circ} \quad 59^{\circ} \quad 59^{\circ}$
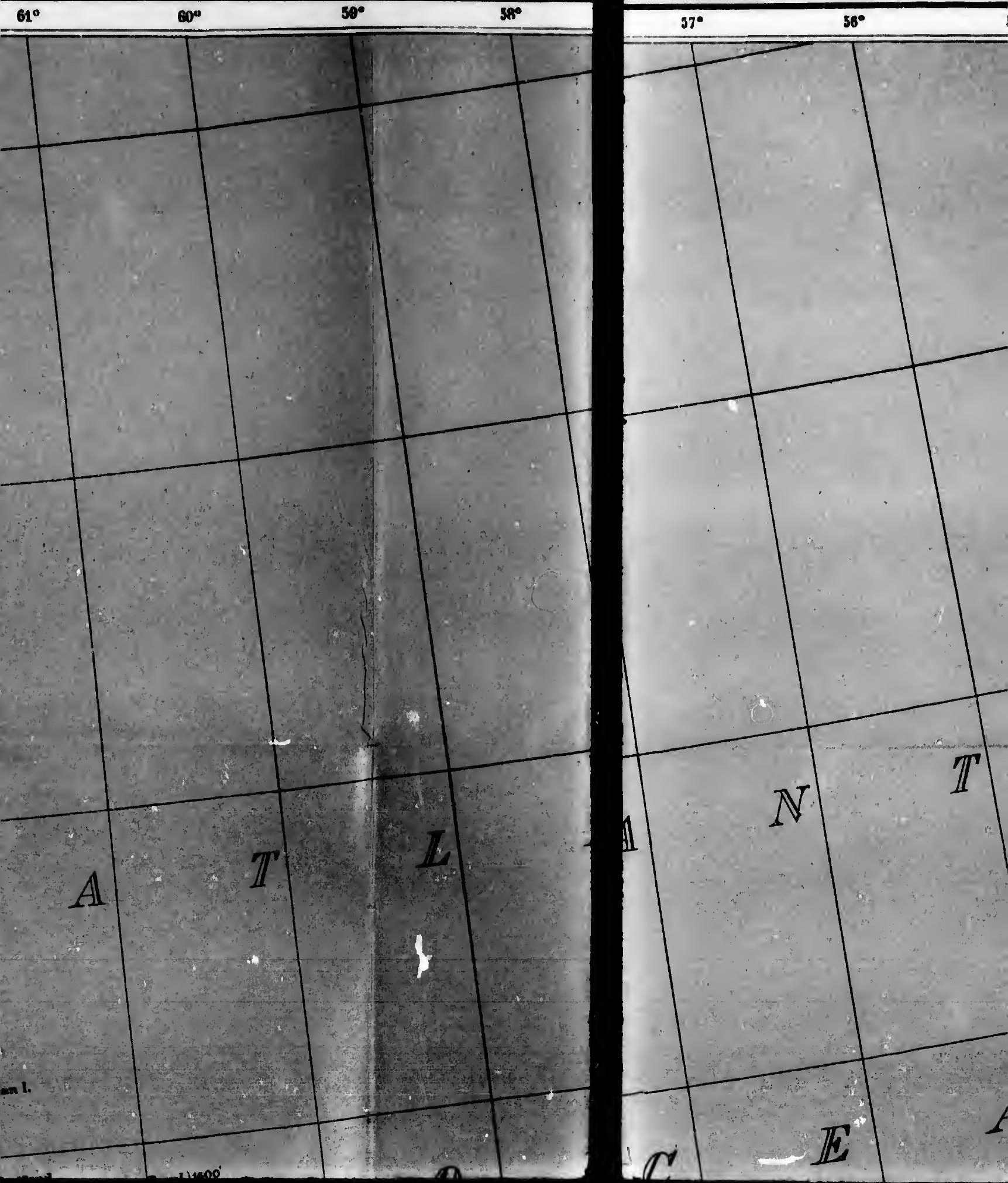

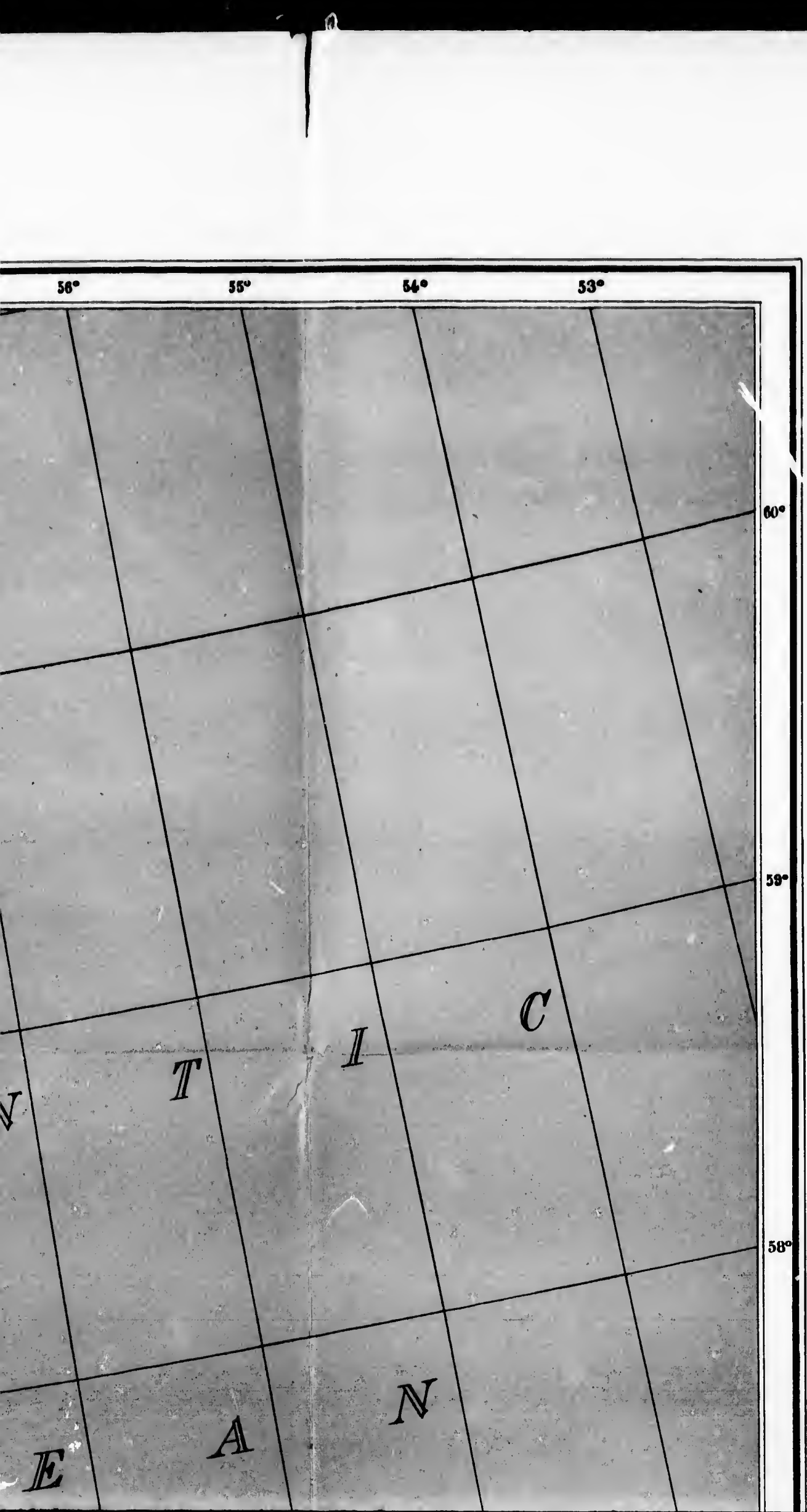
Grive Mrrmuler ronks

Ation

Anordhosiles

linuestane

Glourul striu

1129

Hright ulmotes sen

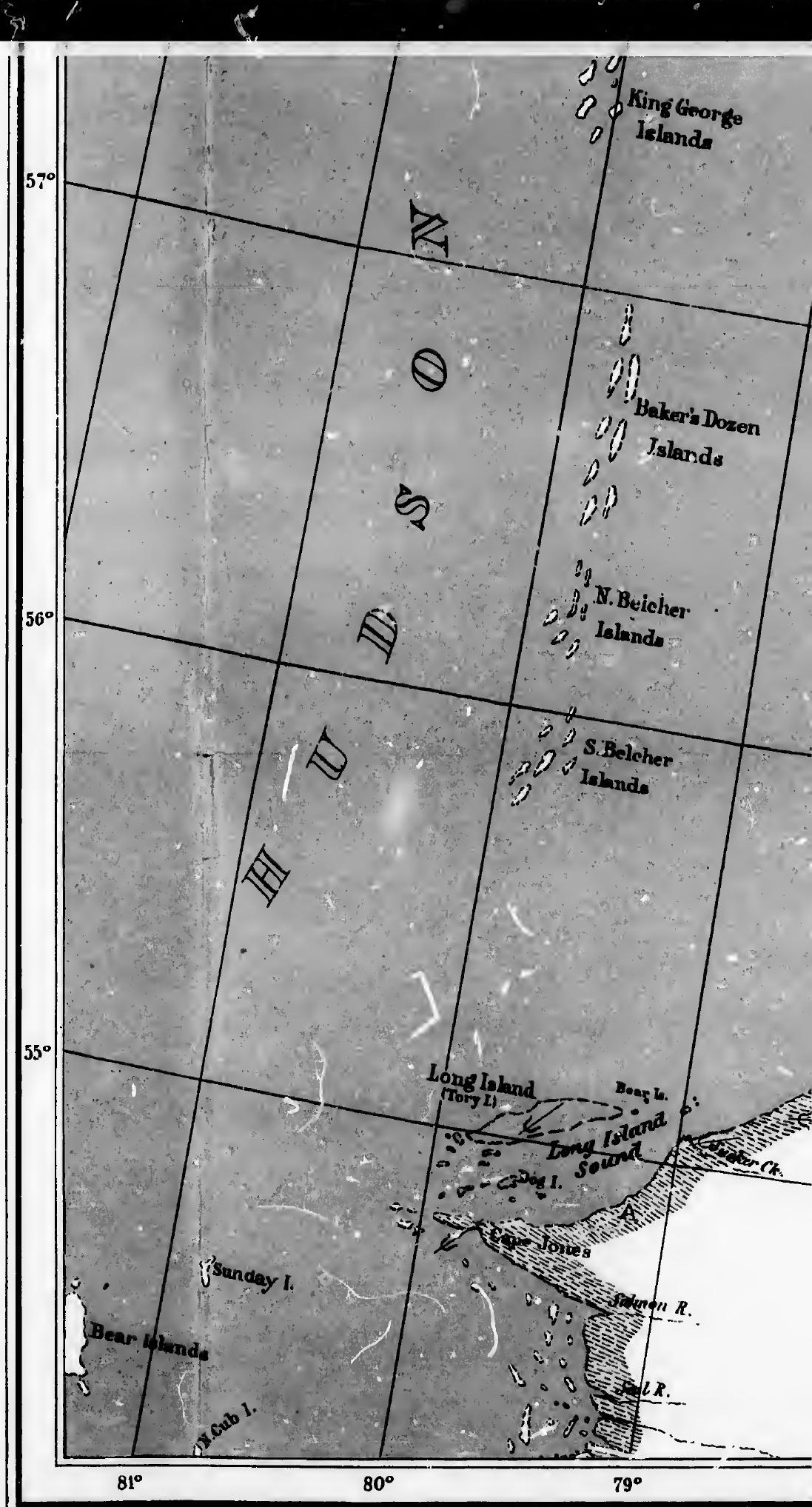

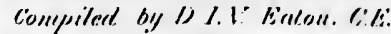

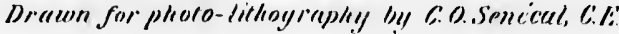

Sout

Couste line from varioos Admirgity Chasts excepting (1) Vast coast of Hudson Hay between Portian (a) Cosst anil islands of James Bay from chart by A. P. Low, 1887.

Rivers of the nouthern waternhed chiafly frem urvey by R. Bell, 1895, Rupert, Fant Main, Kukse Manicusagen and North.west rivers, from surveys b are from sketch (10.9e). The roura between 


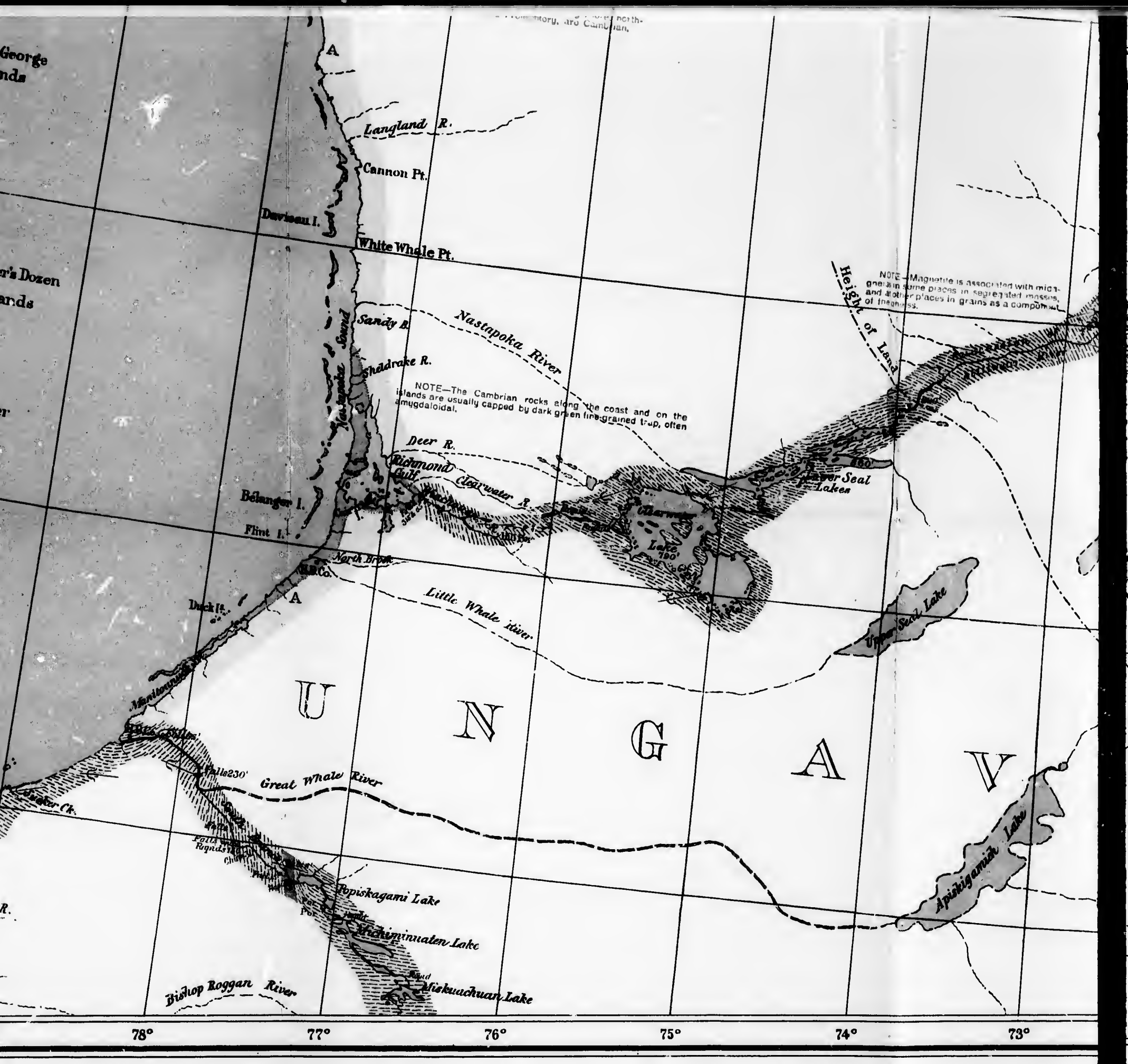

SOURCES OF INFTRMATION. GEOGRAPHICAL.

rroity Charts excepting :

Hay between Portland Promontory and Great Whale River, from map by Dr. R. Bell, 1877.78 Iames Bay from charts of Capts. Taylor nnd Blshop, of the H. B. Co's vessels, with corrections

ateratied chiafly frem surveys of tha Depai ment of Crown Lands, Quelec. Nottaway River froin ort, Fast Main, Kuksosk, Hamilton, Romaine and portions of tw. - Hig, Great Whale, Clearwater, rivers, from surveys by A. P. Low and D. 1. V. Eaton. Rivers and lakes shown in dotted line the Easu Main and Nottaway rivers from a inap compiled by Jas. Clouston (1824).
North West Sheet.

$\frac{\text { MLAP }}{\text { LABRADOR }}$ PENINSULA.

The geolugical in (1) Fucts obl (p. 19, L.), incluc (3) Observati

Natural Scale: utrose.

Scale: 25 miles to one inch 


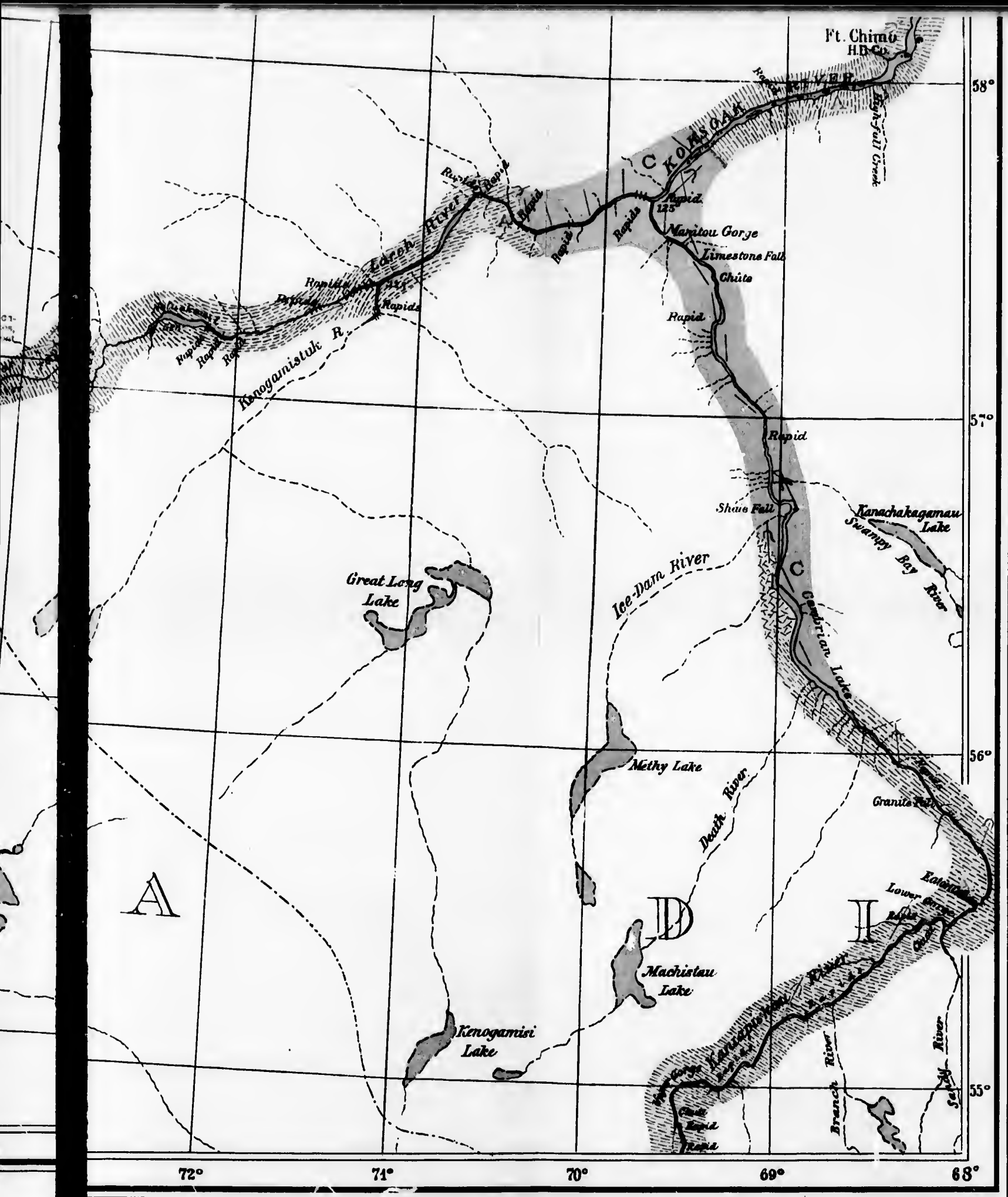

SOLRCES OF INFORMATION

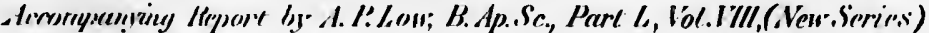
Geolocical.

cations include :

ined during A. P. Low's expetitions of 1892, '93, '94, '95 and 96.

11s contunned in previous reports of the Geological Survey as enumerated in the accompanying report

ng work by J. Kichardson, W. McOuet, R. Hell end F. D. Adams.

ns of $A$. S Packerd on the'coast between Belle Isle and Nain. 


\begin{tabular}{|c|c|}
\hline 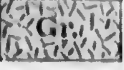 & Mrexsyse ,yrumlen \\
\hline Anor: & 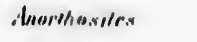 \\
\hline 24 & lomestone \\
\hline 4 & filfwent s/rirr \\
\hline 11291 & Irighle nlinere spa \\
\hline
\end{tabular}

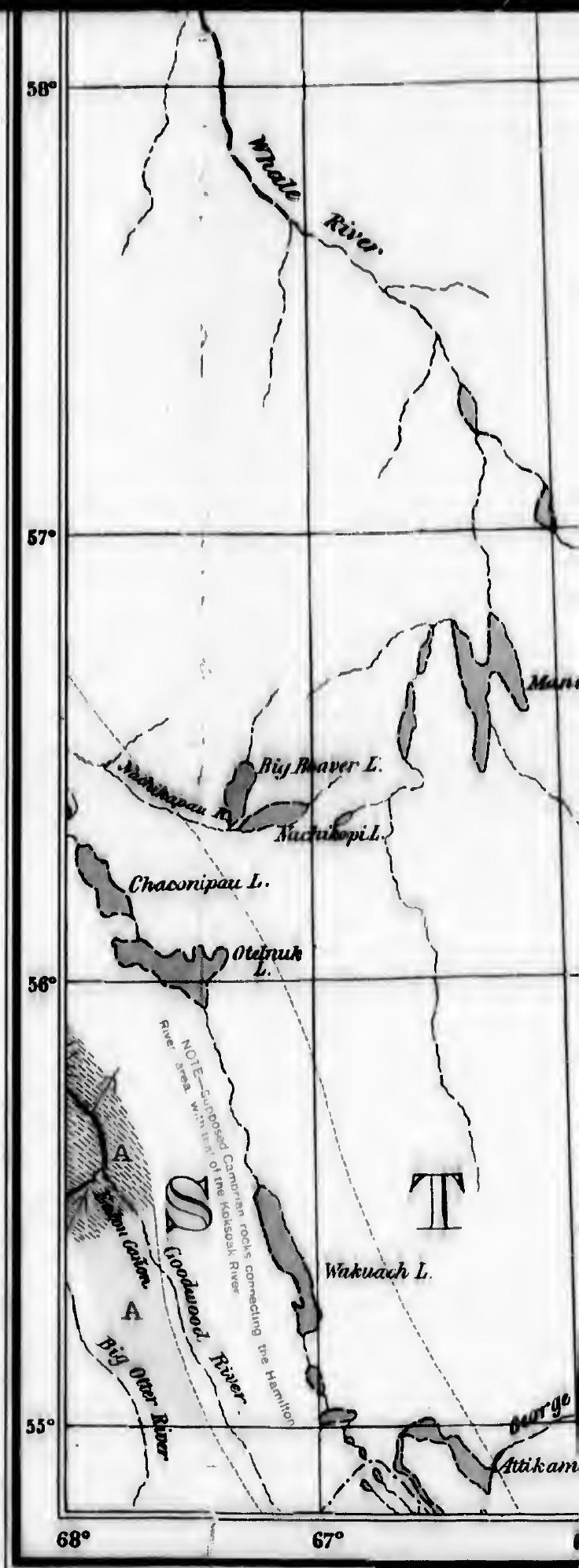

Compriled by D. I. V. Reaton. C.:E

Diveren for photo-lithography by 6. O.Senceal. C.t: 


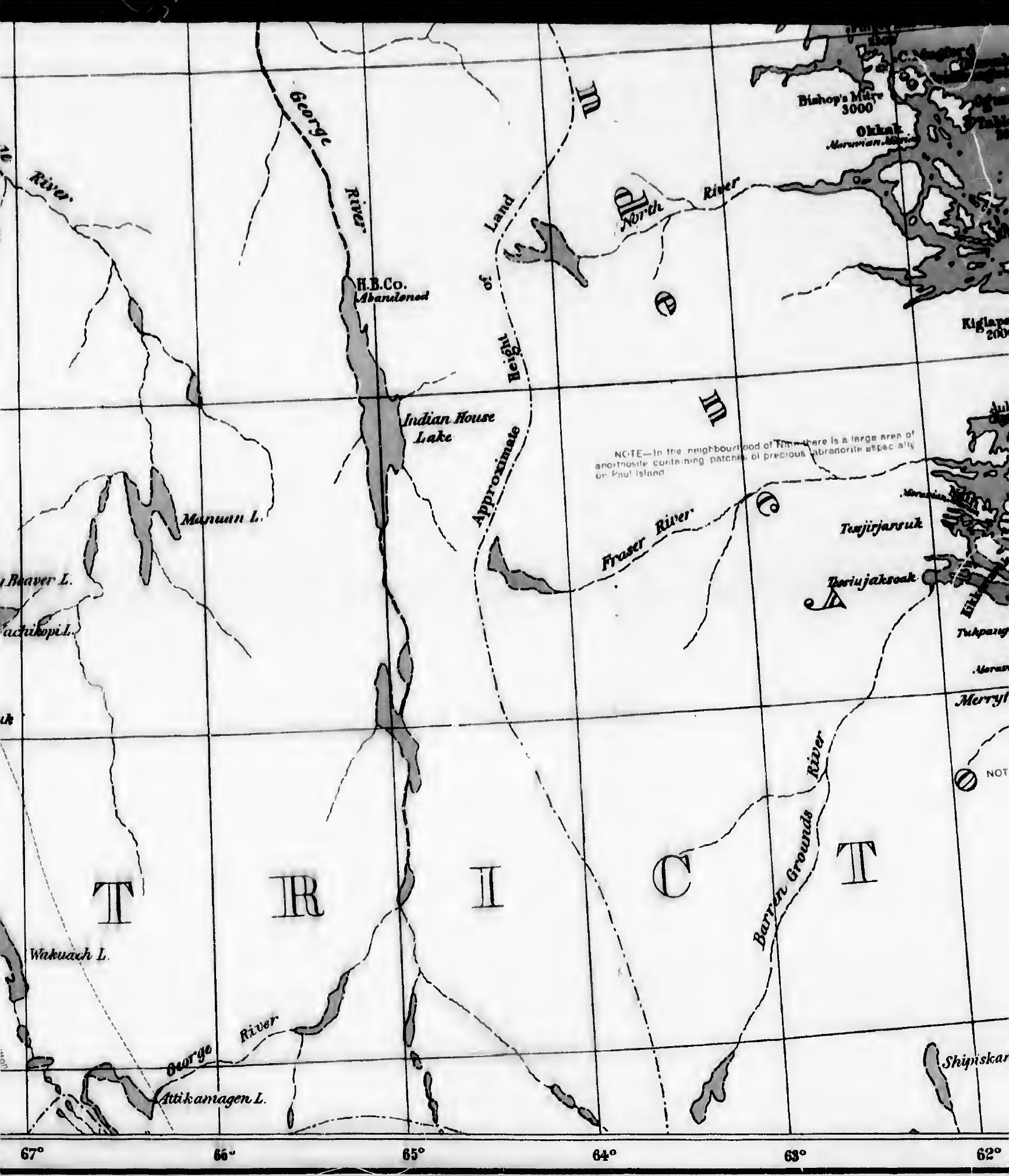

by C.O.Sencical. C.I:

SOURCES OF INFORMATION GEOGRAPHICAL

Cnast lina from various Admiralty Charts excepting :

(2) East coast of Hudson Bay between Portland Promontory and Great Whale River, from map by Dr. R. Bell, $1877 \cdot 78$.

(2) Coast and islands of James Hay from charts of Cnpts. Taylor and Bishop, of the H. B. Co's vessels, with corrections

by A. P. Low, $188_{7}$.

Rivers of the southern watershed chiefly from surveys of the Departnent of Crown Lawls, Quebec. Nottaway River from survey by R. Bell, 1B95, Rupert, Fast Main, Koksank, Hamilton, Romnine and portions of the Big, Great Wilule, Clearwater, Manicungan and Nortli-west rivers, from surveys by A. P. Low and D. 1. V. Enton. Rivers und lakes shown in dotted lines are from sketch-mups of H. B. Co. The central interior from a map macle by John Spencer and John Beads at Niebicun $\left(\mathrm{sB}_{42}\right)$. The routes between the Fast Main and Nottawny rivers from a map compiled by Jas. Clouston (1824). 
